\title{
Land Subsidence in the San Joaquin Valley, California, as of 1980
}

U.S. GEOLOGICAL SURVEY PROFESSIONAL PAPER 437-I

Prepared in cooperation with the California Department of Water Resources

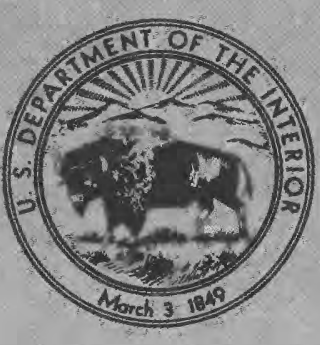


LAND SUBSIDENCE IN

THE SAN JOAQUIN VALLEY,

CALIFORNIA, AS OF 1980 


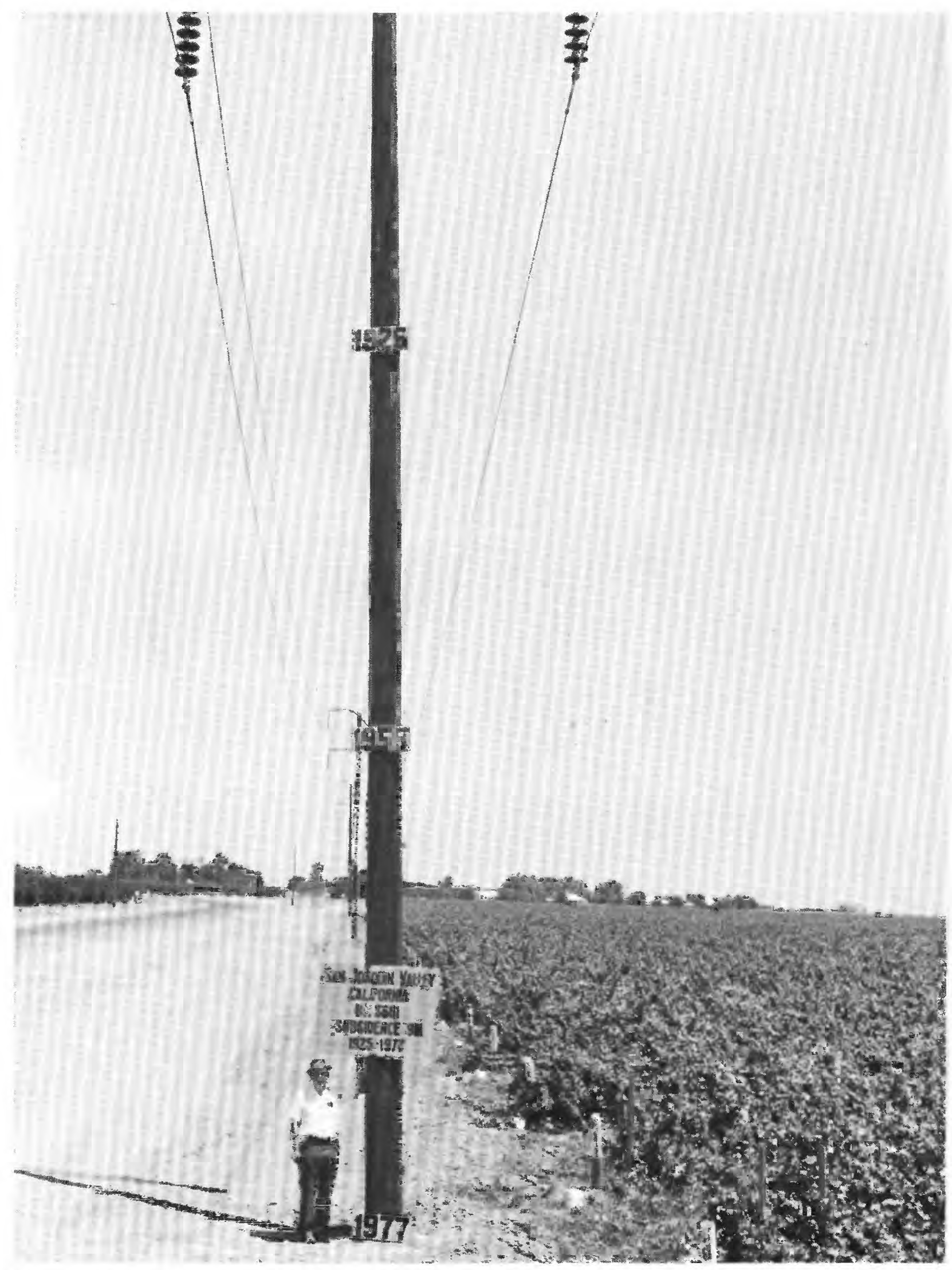

Magnitude of subsidence at a site 10 mi southwest of Mendota in the San Joaquin Valley, Calif. Joseph F. Poland, principal subsidence researcher and coauthor of report, stands alongside a power pole which shows the approximate position of land surface in 1925,1955 , and 1977. Land surface was lowered about $9 \mathrm{~m}$ during that period. 


\section{Land Subsidence in the}

\section{San Joaquin Valley, California, \\ as of 1980}

By R. L. IRELAND, J. F. POLAND, and F. S. RILEY

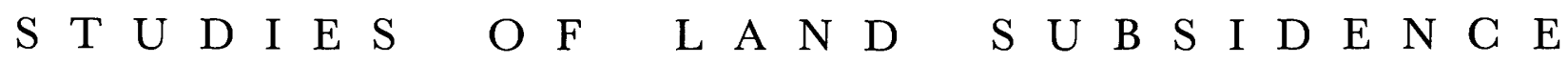

U.S. GEOLOGICAL SURVEY PROFESSIONAL PAPER 437-I

Prepared in cooperation with the

California Department of Water Resources

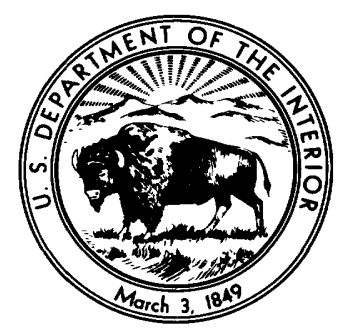




\section{DEPARTMENT OF THE INTERIOR \\ WILLIAM P. CLARK, Secretary}

\section{U.S. GEOLOGICAL SURVEY}

Dallas L. Peck, Director

Library of Congress Cataloging in Publication Data

Ireland, R. L.

Land subsidence in the San Joaquin Valley, California, as of 1980

(Studies of land subsidence) (Geological Survey professional paper; 437-I)

"Prepared in cooperation with the California Department of Water Resources."

Bibliography: p. I58-I60

Supt. of Docs. no.: I 19.16:437-I

1. Subsidences (Earth movements)--California--San Joaquin Valley. 2. Water, Underground--California--San Joaquin Valley. I. Poland, J. F. (Joseph Fairfield), 1908- • II. Riley, Francis S. (Francis Stevenson), 1928- . III. California. Dept. of Water Resources. IV. Title. V. Series. VI. Series: Geological Survey professional paper ; 437-I. GB485.C2I74 $1984 \quad 551.3^{\prime} 5$

$84-600081$

For sale by the Distribution Branch, Text Products Section, U.S. Geological Survey, 604 South Pickett St., Alexandria, VA 22304 


\section{CONTENTS}

\begin{tabular}{|c|c|c|c|}
\hline \multicolumn{3}{|c|}{ Page } & Page \\
\hline Introduction. & 1 & Aqueduct subsidence, mile 92 to mile 174 . & 37 \\
\hline General statement. & 1 & Aqueduct subsidence, mile 174 to mile 218 . . & 39 \\
\hline Causes, history, and extent of subsidence. . . . . . . . . . . & 3 & Aqueduct subsidence, mile 238 to mile 287 . & 41 \\
\hline Acknowledgments. $\ldots \ldots \ldots \ldots \ldots \ldots \ldots \ldots$ & 5 & Monitoring of compaction and change in head $\ldots \ldots \ldots \ldots \ldots$ & 43 \\
\hline Well-numbering system $\ldots \ldots \ldots \ldots \ldots$ & 5 & Computer simulation of aquifer-system compaction . . . . . . . . & 46 \\
\hline atus of subsidence and water-level change. ... . & 7 & Computer plots of field records. $\ldots \ldots \ldots \ldots \ldots \ldots \ldots$ & 50 \\
\hline Arvin-Maricopa area $\ldots \ldots \ldots \ldots \ldots \ldots \ldots$ & 28 & Selected references $\ldots \ldots \ldots \ldots \ldots \ldots \ldots \ldots$ & 58 \\
\hline stablishment and releveling of bench-mark network & 28 & & \\
\hline
\end{tabular}

\section{ILLUSTRATIONS}

Plate 1. Profiles of land subsidence along the California Aqueduct in the Los Banos-Kettleman City area, south of Kettleman City, and in the Arvin-Maricopa area, California . . . . . . . . . .

FIGURE 1. Map showing geographic features of central and southern San Joaquin Valley and areas affected by subsidence........... I 2

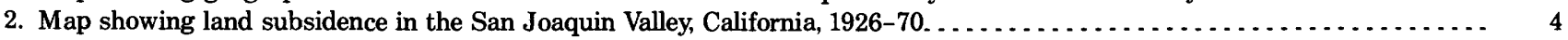

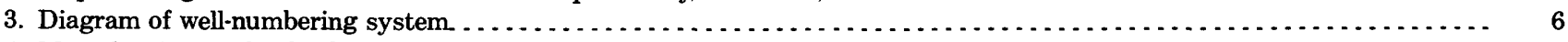

4. Map showing land subsidence, 1926-72, Los Banos-Kettleman City area . . . . . . . . . . . . . . . . . . . . . . . . 8

5. Graph showing generalized water-level profiles for the lower water-bearing zone beneath the California Aqueduct, 1943 to 1976, showing change from the 1943 level, Los Banos-Kettleman City area . . . . . . . . . . . . . . . . . . . . . . . .

6. Map showing location of California Aqueduct, subsidence profiles, selected observation wells, nearby bench marks, and boundaries of principal confining beds.

7-14. Maps of the Los Banos-Kettleman City area, showing generalized water-level contours for the lower water-bearing zone:

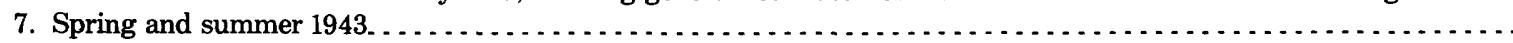

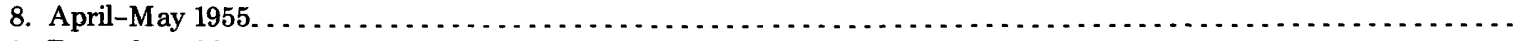

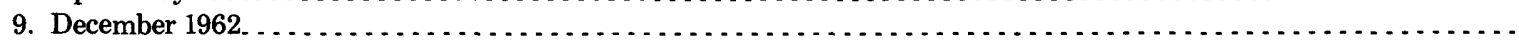

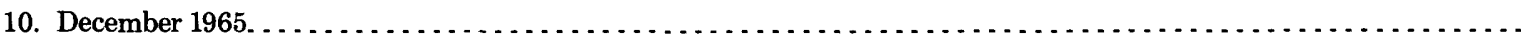

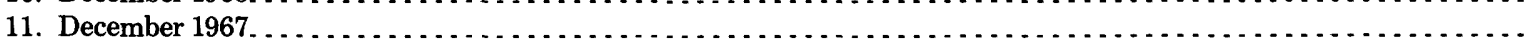

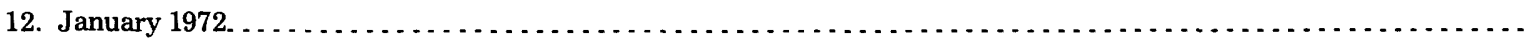

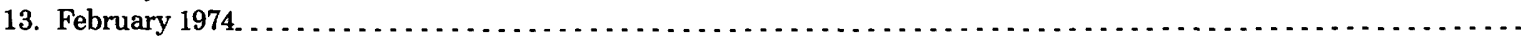

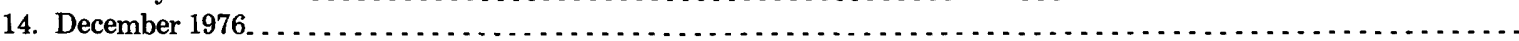

15. Generalized water-level change for the lower water-bearing zone, December 1967 to February 1974, in the Los Banos-Kettleman City area.

16. Graph showing subsidence and artesian-head change, 10 miles southwest of Mendota, and photograph illustrating magni-

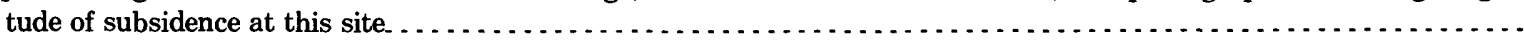

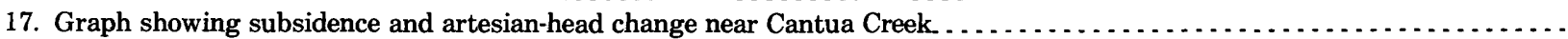

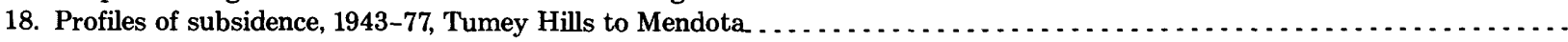

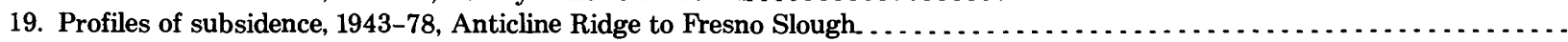
20-24. Graphs showing:

20. Long-term trend of water levels near the town of Cantua Creek, and seasonal high- and low-levels in observation

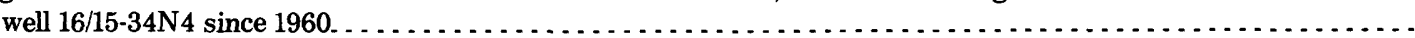

21. Seasonal fluctuations of water level in well $16 / 15-34 \mathrm{~N} 4$ and measured compaction in observation well 16/15-34N1 near Cantua Creek.

22. Seasonal fluctuations of water level and measured compaction in well 14/13-11D6 southwest of Mendota . . . . . . ...

23. Seasonal fluctuations of water level and measured compaction in well 17/15-14Q1 south of the town of Cantua Creek.

24. Seasonal fluctuations of water level and measured compaction in well 20/18-6D1 northeast of Huron . . . . . . . . . . .

25. Map showing land subsidence, 1926-70, and location of subsidence profiles, Tulare-Wasco area . . . . . . . . . . . . . . . .

26. Profiles of land subsidence, 1957-74, from bench mark 59S, west of Woody, to 19 miles west of Delano . . . . . . . . . . . . .

27. Profiles of land subsidence, 1957-74, from Wasco to near Lost Hills. 
28. Graph showing long-term trend of water levels near Pixley, and seasonal high and low artesian head in observation well

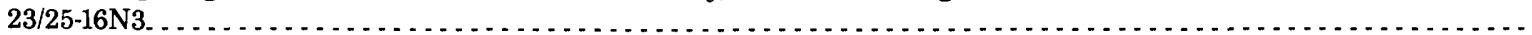

29. Graph showing seasonal fluctuations of water level in observation well $23 / 25-16 \mathrm{~N} 3$ and measured compaction in well

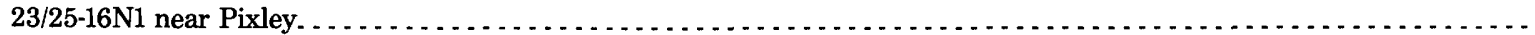

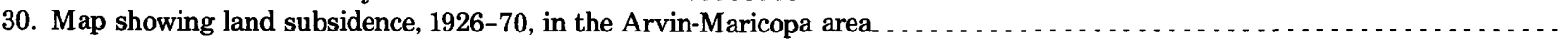

31. Graph showing seasonal fluctuations of water level and measured compaction in well $11 \mathrm{~N} / 21 \mathrm{~W}-3 \mathrm{~B} 1 \ldots \ldots \ldots \ldots \ldots \ldots . . . .$.

32. Map showing network of leveling by the National Geodetic Survey and three areas of detailed studies of land subsidence.... 33-35. Maps showing extent and times of leveling:

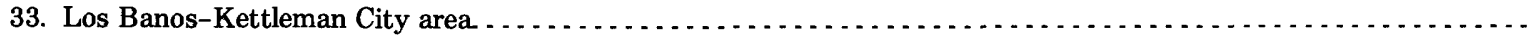

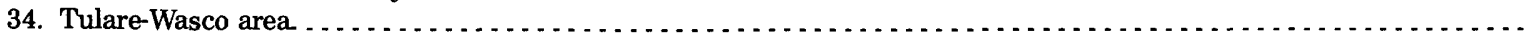

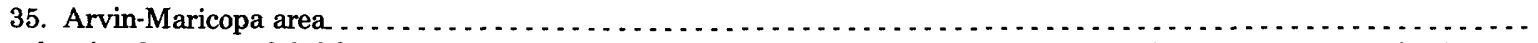

36. Map showing location of California Aqueduct subsidence and water-level profiles and areas of hydrocompaction in the Los

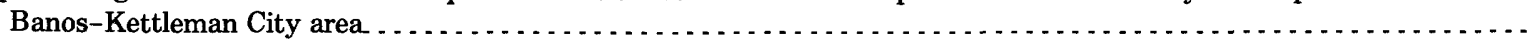

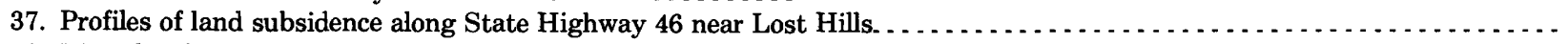

38. Map showing areas of known hydrocompaction in the Arvin-Maricopa area $\ldots \ldots \ldots \ldots$

39. Diagram of recording extensometer installations. $\ldots \ldots \ldots$

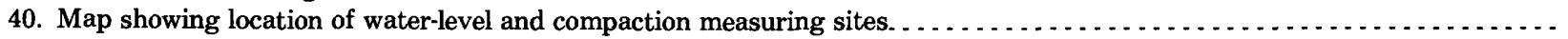

41.-66. Computer plots showing:

41. Hydrographs, compaction, and subsidence, 12/12-16H. $\ldots \ldots \ldots \ldots \ldots$

42. Hydrograph, compaction, and subsidence, 13/12-20D1 $\ldots \ldots \ldots \ldots$

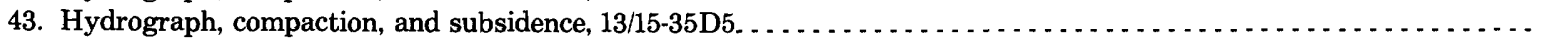

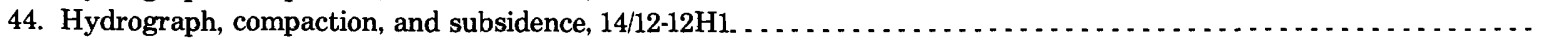

45. Hydrographs, change in applied stress, compaction, subsidence, and stress-strain relationship, 14/13-11D . . . . . . . . .

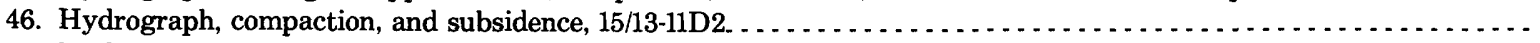

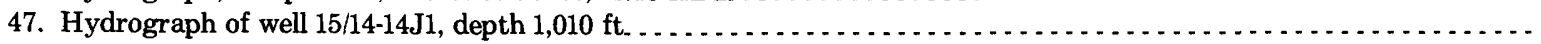

48. Hydrograph, change in applied stress, compaction, subsidence, and stress-compaction relationship $15 / 16-31 \mathrm{~N} 3 \ldots . . .$.

49. Hydrographs, change in applied stress, compaction, subsidence, casing separation, and stress-strain relationship,

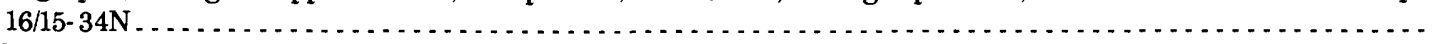

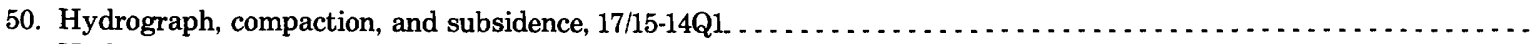

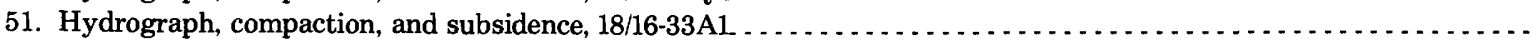

52. Hydrographs, change in applied stress, compaction, subsidence, and stress-strain relationship, 18/19-20P. . . . . . . . .

53. Hydrograph, change in applied stress, compaction, subsidence, and stress-compaction relationship, 19/16-23P2 . . . . .

54. Hydrograph, compaction, and subsidence, 20/18-6D1 $\ldots \ldots \ldots \ldots$

55. Hydrograph, compaction, stress-compaction relationship, 20/18-11Q1 . . . . . . . . . . . . . . . . . . . . . . . . .

56. Hydrograph, change in applied stress, compaction, subsidence, and stress-strain relationship, 20/18-11Q3. . . . . . . . .

57. Hydrograph, change in applied stress, compaction, and stress-compaction relationship, 22/27-30D2 . . . . . . . . . .

58. Hydrographs, change in applied stress, compaction, subsidence, and stress-strain relationship, 23/25-16N . . . . . . . .

59. Hydrographs, change in applied stress, compaction, and stress-strain relationship, 23/25-16N3 and 4. . . . . . . . . . .

60. Hydrograph, change in applied stress, compaction, subsidence, and stress-compaction relationship, 24/26-34F1 ..... .

61. Hydrograph and change in applied stress at 25/26-1A2, compaction, subsidence, and stress-compaction relationship at well 24/26-36A2.

62. Hydrograph, change in applied stress, compaction, and stress-compaction relationship, 25/26-1A2

63. Hydrographs, change in applied stress, compaction, and stress-compaction relationship, $26 / 23-16 \mathrm{H} . \ldots . . . . . . .$.

64. Hydrograph, change in applied stress, compaction, subsidence, and stress-compaction relationship, 32/28-20Q1.....

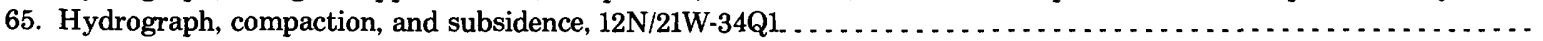

66. Hydrograph, change in applied stress, compaction, subsidence, and stress-compaction relationship, $11 \mathrm{~N} / 21 \mathrm{~W}-3 \mathrm{~B} 1$... .

67. Graph showing relation of compaction/subsidence ratios to depth at extensometer wells in the San Joaquin Valley. .........

Page I29

\section{TABLES}

TABLE 1. Years of leveling control of the network of bench marks in three subsidence areas by the National Geodetic Survey..........

2. Surface-water deliveries through the joint-use reach of the California Aqueduct and estimated ground-water pumpage in the

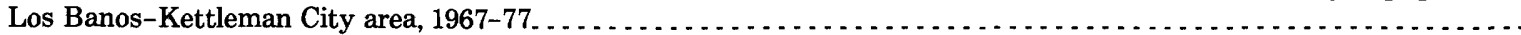

3. Annual compaction at compaction-measuring sites, San Joaquin Valley $\ldots \ldots \ldots \ldots \ldots$

4. Computer simulation of aquifer-system compaction $\ldots \ldots \ldots \ldots$

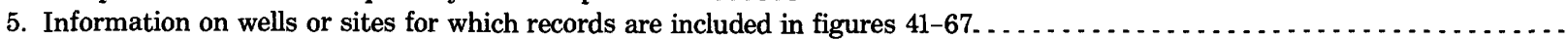

6. Ratio of compaction to subsidence for periods of leveling in the Los Banos-Kettleman City, Tulare-Wasco, and Arvin-Maricopa areas. 


\section{CONVERSION FACTORS}

The inch-pound system of units is used in this report. For readers who prefer metric (SI) units, the conversion factors for the terms used are listed below:

Multiply

acre

acre-ft (acre-foot)

ft (foot)

inch (in.)

mi (mile)

$\mathrm{mi}^{2}$ (square mile)
$B y$

\section{7}

1233

0.3048

2.54

1.609

2.590
To obtain

$\mathrm{m}^{2} \quad$ (square meter)

$\mathrm{m}^{3} \quad$ (cubic meter)

m (meter)

cm (centimeter)

km (kilometer)

$\mathbf{k m}^{2}$ (square kilometer)

National Geodetic Vertical Datum of 1929 (NGVD of 1929): A geodetic datum derived from a general adjustment of the first-order level nets of both the United States and Canada, formerly called mean sea level. NGVD of 1929 is referred to as sea level in this report. 

STUDIES OF LAND SUBSIDENCE

\title{
LAND SUBSIDENCE IN THE SAN JOAQUIN VALLEY, CALIFORNIA, AS OF 1980
}

\author{
By R. L. IRELAND, J. F. POLAND, and F. S. RILEY
}

\begin{abstract}
Land subsidence due to ground-water overdraft in the San Joaquin Valley began in the mid-1920's and continued at increasing rates until surface water was imported through major canals and aqueducts in the 1950 's and late 1960's. In areas where surface water replaced withdrawal of ground water, water levels in the confined system rose sharply and subsidence slowed or essentially eased.

The three major subsiding areas in the San Joaquin Valley in this report are the Los Banos-Kettleman City area, largely in western Fresno County; the Tulare-Wasco area, mostly in Tulare County; and the Arvin-Maricopa area, in Kern County.

The latest areawide leveling was in 1972 in the Los Banos-Kettleman City area and in 1969-70 in the Tulare-Wasco and Arvin-Maricopa areas. The 1972 leveling in the Los Banos-Kettleman City area showed that subsidence rates had decreased sharply with the importation of surface water through the California Aqueduct in the late 1960's and early 1970's. The California Aqueduct leveling showed a continued decrease in the rate of subsidence along the aqueduct through 1975, followed by increased subsidence during the drought years of 1976-77.

Leveling by the Los Angeles Department of Water and Power in the Tulare-Wasco area showed that east and west of Delano, subsidence continued into 1974 . In the late 1960's and early 1970's, water levels in wells recovered to levels of the 1940's and 1950's throughout most of the western and southern parts of the valley, in response to decreased ground-water withdrawals because of the importation of surface water through the California Aqueduct. Concurrently, the borehole extensometers recorded decreasing compaction rates. By the mid-1970's, compaction had diminished to near zero at some sites.

Data collected at water-level and extensometer sites during the 1976-77 drought showed the effect of the heavy demand on the groundwater reservoir. With the water of compaction gone, artesian head declined 10 to 20 times as fast as during the first cycle of long-term drawdown that ended in the late 1960's. Extensometers measured compaction ranging from 0.1 to 0.5 foot in 1977. In 1978-79 water levels recovered to or above the 1976 predrought levels. Extensometer response ranged from compaction of a few hundredths of a foot to expansion of nearly 0.20 foot.

The report suggests continued monitoring of land subsidence in the San Joaquin Valley, utilizing extensometers, water-level recorders or measurements, and periodic releveling.
\end{abstract}

\section{INTRODUCTION}

\section{GENERAL STATEMENT}

The San Joaquin Valley (fig. 1) is a broad alluviated structural trough constituting the southern two- thirds of the Central Valley of California. It is $250 \mathrm{mi}$ long, averages $40 \mathrm{mi}$ in width, and encompasses 10,000 $\mathrm{mi}^{2}$ excluding the rolling foothills that skirt the valley on three sides. The pertinent geographic features of the area discussed in this report are those in the southern four-fifths of the valley (fig. 1).

Land subsidence due to ground-water withdrawal began in the San Joaquin Valley in the mid-1920's and locally exceeded $28 \mathrm{ft}$ by 1970 (Poland and others, 1975); in December 1977, subsidence reached a maximum of $29.6 \mathrm{ft}$ in western Fresno County. More than $5,200 \mathrm{mi}^{2}$ of irrigable land, one-half the entire valley, has been affected by subsidence.

Subsidence in the San Joaquin Valley probably represents one of the greatest single manmade alterations in the configuration of the Earth's surface in the history of man. It has caused serious and costly problems in construction and maintenance of water-transport structures, highways, and highway structures; also many millions of dollars have been spent on the repair or replacement of deep water wells. Subsidence, besides changing the gradient and course of valley creeks and streams, has caused unexpected flooding, costing farmers many hundreds of thousands of dollars in recurrent land leveling.

Not all the effects of subsidence due to ground-water withdrawal have been negative. Benefits attributable to or associated with subsidence include: (1) The tremendous volume of water of compaction released to wells as subsidence progressed; thus, water levels declined more slowly, and pumping lifts were less than would have occurred if comparable volumes had been withdrawn from a less compressible aquifer system; (2) the compressible deposits of the ground-water reservoir have been "preconsolidated" by earlier pumping stresses-rapidly draining beds to the maximum stresses of the mid-1960's, slowly draining beds to some lesser stress; within the range of stresses in which preconsolidation has actually been accomplished-which can only be determined by precise field measurements-the ground-water reservoir can be 
managed for cyclic storage without appreciable future subsidence; (3) the basin has provided a field laboratory for testing compression characteristics of complex aquifer systems on site and for measuring mechanical and storage characteristics of aquifer systems under a wide range of loading stresses.

After many years of continued water-level decline and subsidence, water levels recovered because of the

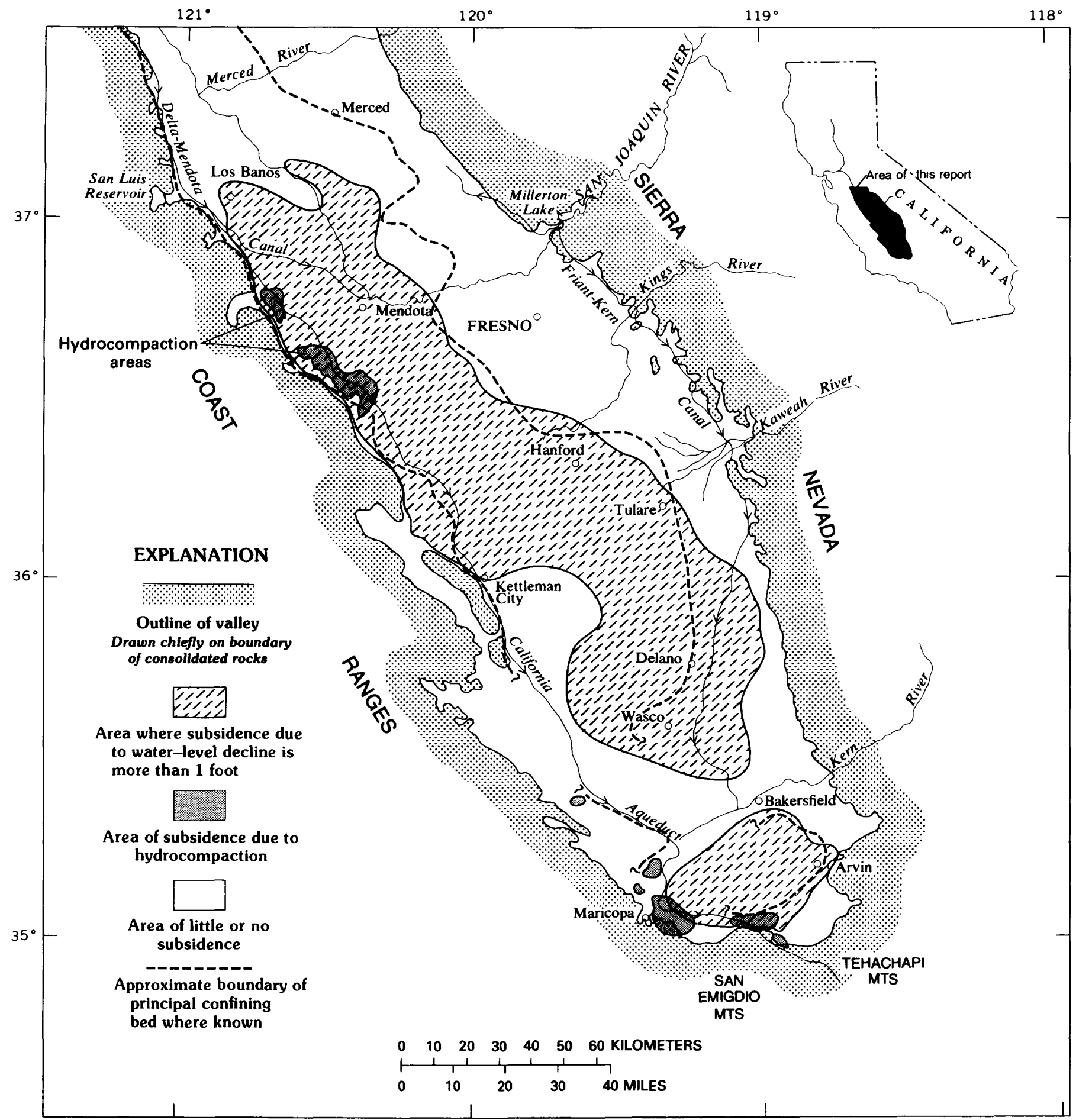

Figure 1.-Geographic features of central and southern San Joaquin Valley and areas affected by subsidence. Base from U.S. Geological Survey, 1:1,000,000, State of California map, 1940. 
importation of surface water and the decrease of ground-water pumping in the late 1960's and 1970's. Then, during the drought of 1976-77, heavy groundwater pumping caused renewed subsidence, and water levels declined at a much faster rate than during the first period of decline because of the reduced storage capacity due to compaction of the compressible materials in the aquifer system.

\section{CAUSES, HISTORY, AND EXTENT OF SUBSIDENCE}

Four types of subsidence occur in the San Joaquin Valley. In order of decreasing magnitude, they are (1) subsidence caused by water-level decline (ground-water overdraft) and consequent compaction of aquifer systems, (2) subsidence related to the hydrocompaction ${ }^{1}$ of moisturedeficient deposits above the water table, (3) subsidence related to fluid withdrawal from oil and gas fields, and (4) subsidence caused by deep-seated tectonic movements. A fifth type, subsidence caused by the oxidation and compaction of peat soils, occurs in the Sacramento-San Joaquin Delta area.

The primary causes of subsidence in the San Joaquin Valley are aquifer-system compaction due to water-level decline and near-surface hydrocompaction. The data presented in this report are mostly related to these two types of subsidence. The areas (fig. 1) affected by subsidence caused by water-level decline and hydrocompaction are principally in the western and southern parts of the valley where runoff from surface streams is minimal.

Most of the subsiding area in the San Joaquin Valley is underlain by a continuous and extensive confining bed; and most of the pumping overdraft and compaction due to head decline occurs in the confined aquifer system beneath this bed. The approximate boundary of the confining bed, where known, is shown in figure 1 (Lofgren and Klausing, 1969; Miller and others, 1971; Croft, 1972). North of Wasco, the confining bed is the Pleistocene Corcoran Clay Member of the Tulare Formation, which also has been called the E-clay by Croft (1972). The boundary of the confining bed (fig. 1) conforms fairly closely with the area affected by subsidence, except in the semiconfined system east of Delano (Lofgren and Klausing, 1969). For convenience, the unconfined to semiconfined water-bearing deposits above the confining bed are referred to as the upper water-bearing zone and the confined system beneath the confining bed as the lower water-bearing zone.

1Hydrocompaction is the process of volume decrease and density increase that occurs when moisture-deficient deposits become compacted as they are wetted for the first time since burial (Prokopovich, 1963; Lofgren, 1969, p. 273). The vertical downward movement of the land surface that results from this process has been called "shallow subsidence" (InterAgency Committee on Land Subsidence in the San Joaquin Valley, 1958, p. 22) and "nearsurface subsidence" (Lofgren, 1960; Bull, 1964a).
Subsidence due to hydrocompaction has occurred in two areas west and southwest of Mendota (Bull, 1964a), a small area just south of Kettleman City (not shown in fig. 1), and in five areas south and southwest of Bakersfield (California Department of Water Resources, 1964, pl. 2; Lofgren, 1975, pl. 3C). The total area known to be susceptible to hydrocompaction is about $225 \mathrm{mi}^{2}$, of which about $145 \mathrm{mi}^{2}$ is north of Kettleman City (Prokopovich, 1970).

The magnitude and extent of land subsidence in the San Joaquin Valley (fig. 2) from 1926 to 1970 has been compiled from topographic maps and leveling data.

Agricultural development in the San Joaquin Valley has been intensive, especially since World War II. In the eastern part of the valley, from Kings River to the north, surface streams from the Sierra Nevada supply most of the water for irrigation but the surface streams are supplemented by ground water, especially after midsummer when streamflow is deficient. From Kaweah River to the south-except for the Kern River and its alluvial fanand in the west-central area from Mendota to Kettleman City, local surface-water supplies have been small to negligible. Prior to the construction of major canals or aqueducts, irrigation was almost wholly from thousands of large and deep irrigation wells; conditions of ground-water overdraft had prevailed since the 1930's. Extractions of ground water in the San Joaquin Valley for irrigation increased from 3 million acre-ft in 1942 to at least 10 million acre-ft in 1966 (Ogilbee and Rose, 1969a, 1969b; Mitten and Ogilbee, 1971).

Importation of surface water to areas of serious overdraft on the east side of the valley began in 1950 when water from the San Joaquin River was brought south through the Friant-Kern Canal, which extends to the Kern River (fig. 1). The average annual delivery from this canal is about 1 million acre-ft. Of this total, an average of 750,000 acre-ft per year was delivered to irrigation districts in the Tulare-Wasco area from 1956 through 1972 (Poland and others, 1975, table 4).

Surface-water imports to the northwestern part of the area from the Sacramento-San Joaquin Delta via the Delta-Mendota Canal began in the early 1950's. About two-thirds of the water in the Delta-Mendota Canal that is transported southward to the San Joaquin River at the Mendota Pool is used by west-side irrigation companies in exchange for water formerly taken from the San Joaquin River, thus releasing rights to water behind Friant Dam for east-side deliveries through the FriantKern Canal. The remaining one-third of the water from the Delta-Mendota Canal is delivered to irrigation contractors along the canal (William R. Cooke, U.S. Bureau of Reclamation, oral commun., 1981).

From 1968 to 1971, when surface water from the California Aqueduct became available to deficient areas on 
the west side and to the south end of the valley, extractions of ground water decreased. Ground-water pumpage in the San Joaquin Valley as a whole decreased 1 to 2 million acre-ft a year from 1969 through the early 1970's (Mitten, 1976). From 1974 through 1976, pumpage in the Los Banos-Kettleman City area averaged less than
100,000 acre-ft annually. Ground-water levels began to recover in those areas during 1969-71 and subsidence rates decreased.

During the drought years, 1976-77, surface water was in short supply, and many new wells were drilled and old wells were reactivated. Estimates by Harris [Pacific

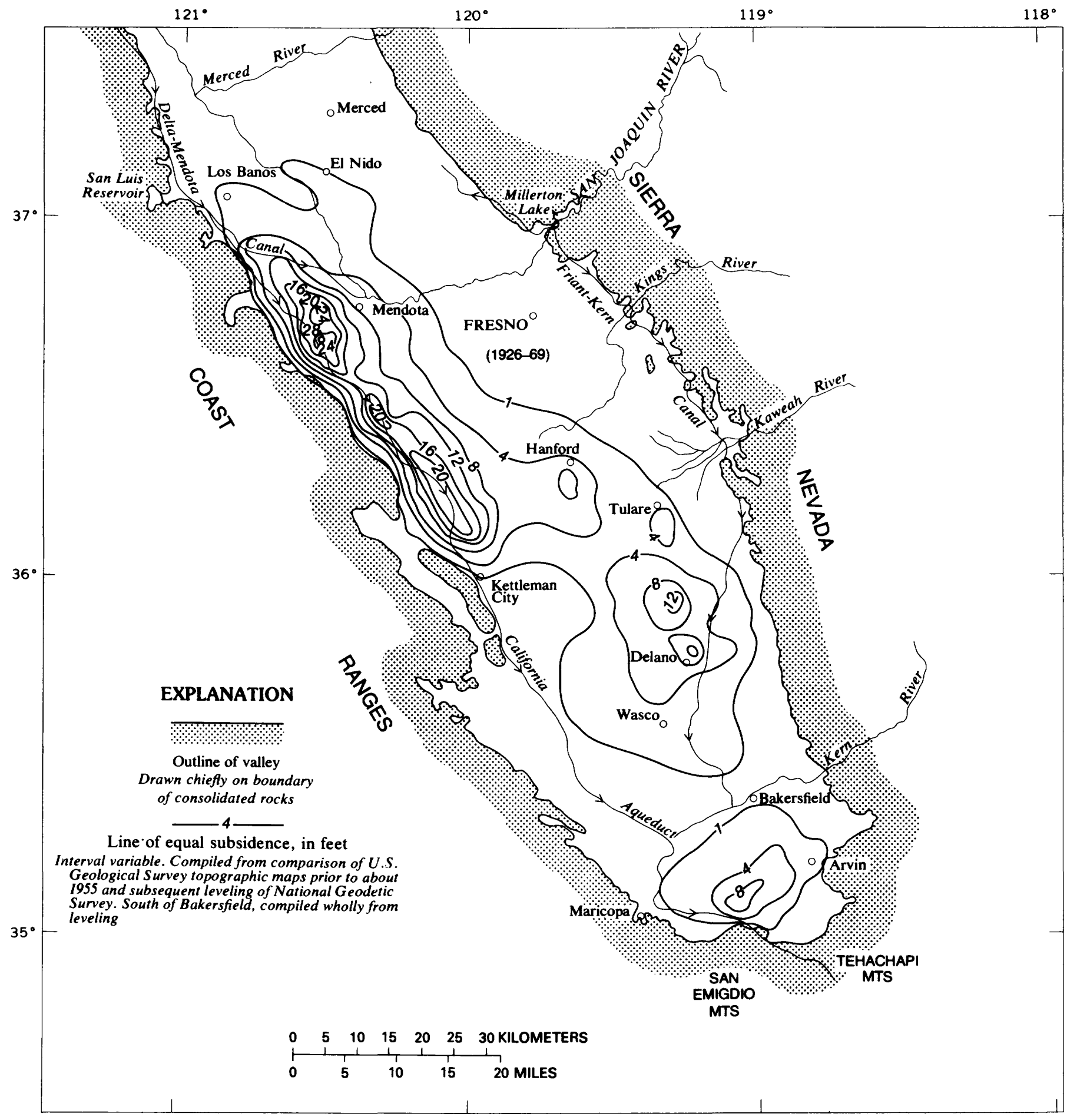

FIGURE 2.-Land subsidence in the San Joaquin Valley, California, 1926-70. Base from U.S. Geological Survey, 1:1,000,000, State of California map, 1940. 
Gas and Electric Co.] (1977) and the Geological Survey indicated a steady increase in ground-water pumpage for the entire San Joaquin Valley from $91 / 2$ million acre-ft in 1974 to 13 million acre-ft in the drought year 1977. In the Los Banos-Kettleman City area pumpage increased to 470,000 acre-ft, and surface-water deliveries were 308,000 acre-ft in 1977 compared to $1,337,100$ acre-ft in 1976 (U.S. Bureau of Reclamation, 1978).

During 24 years that subsidence and water-level data were collected, water levels were drawn down to historical lows in the late 1960's causing subsidence rates that locally exceeded $1 \mathrm{ft}$ per year. After the delivery of surface water, heads recovered in the middle 1970's to levels of the 1940's, and subsidence nearly ceased. During the drought of 1976-77 renewed demand was imposed on the aquifer systems. The resulting second cycle of head decline proceeded much more rapidly than the first cycle because the water of compaction produced by each foot of head decline was only a small fraction of that produced during the first cycle. Associated with the rapid head decline were subsidence rates typical of those observed during the late 1960's.

In 1980, when seasonal rainfall was above normal and surface water was available, ground-water levels recovered above their pre-drought levels and subsidence rates again were low.

This report is an update of an earlier work. It contains data on fluctuation of water levels, associated compaction and expansion of the aquifer systems as measured in extensometer wells, and subsidence of the land surface since 1970. Basic-data graphs and computerplotted stress-strain relationships constitute a major part of this report. They are based on 8-24 years of detailed field measurements of both water-level change and compaction collected by the U.S. Geological Survey at 24 selected locations in the San Joaquin Valley.

\section{PURPOSE OF REPORT}

This report is part of a study of land subsidence in California in cooperation with the California Department of Water Resources; the study has been closely interrelated with a Federal research investigation of the mechanics of aquifer systems. Subsidence in the San Joaquin Valley has been studied in this cooperative program since 1956. The Geological Survey published a report by Poland and others (1975) that summarized land subsidence in the San Joaquin Valley through 1972. The report also contained an annotated bibliography of the principal published reports resulting from the two research studies. The reader interested in learning more about the scope and findings of those reports is referred to Poland's annotated bibliography.
The purposes of this report are (1) to review the status of water-level trends and of subsidence in the San Joaquin Valley through 1979; (2) to present updated water-level, compaction, and subsidence data; (3) to present profiles of land subsidence along the California Aqueduct based on relevelings since the 1967 or 1970 base leveling, in order to define the extent and magnitude of subsidence that has occurred along the aqueduct and to identify probable causes where practicable; and (4) to propose a continuing surveillance program for monitoring areas of continuing or potential subsidence, with special attention to conditions along and near the California Aqueduct in the San Joaquin Valley. The report incorporates field data through December 1979.

\section{ACKNOWLEDGMENTS}

The writers acknowledge the cooperation of Federal, State, and local agencies, irrigation districts, private companies, and individuals. Leveling data used in the preparation of the various subsidence maps and graphs and in calculating magnitude and rates of subsidence were almost all by the National Geodetic Survey, a component of the National Ocean Survey (formerly the U.S. Coast and Geodetic Survey); the 1977-78 leveling along the California Aqueduct was by the California Department of Water Resources.

Water-level data used in this report were chiefly from field measurements made by the Geological Survey, but some records were from the U.S. Bureau of Reclamation, the California Department of Water Resources, Pacific Gas and Electric Co., and irrigation districts. Many Survey workers have contributed to this continuing program.

\section{WELL-NUMBERING SYSTEM}

The well-numbering system (fig. 3) used in California by the Geological Survey and the State of California shows the locations of wells according to the rectangular system for the subdivision of public lands. For example, in the number 12/12-16H2, the part of the number preceding the slash indicates the township (T. $12 \mathrm{~S}$.), the part between the slash and the hyphen shows the range (R. 12 E.), the number between the hyphen and the letter indicates the section (sec. 16), and the letter following the section number indicates the 40-acre subdivision of the section. Within each 40-acre tract, wells are numbered serially as indicated by the final digit of the well number. Thus, well 12/12-16 H2 is the second well listed in the SE $1 / 4$ of the NE $1 / 4$ of sec. 16, T. 12 S., R. 12 E. Except for the extreme south end of the valley, which is referenced to the San Bernardino base and meridian, all wells are referenced to the Mount Diablo base and meridian. 
In this report wells referenced to the Mount Diablo base and meridian are all located south and east of the base and meridian, making all township numbers south and all range numbers east. Therefore, as in the example above, the abbreviations $\mathrm{S}$ and $\mathrm{E}$ are omitted from the well number for brevity. Wells referenced to the San Bernardino base and meridian are all north and west of the base and meridian and are identified by inclusion of the abbreviations $\mathrm{N}$ and $\mathrm{W}$ in the township-and-range part of the well number.

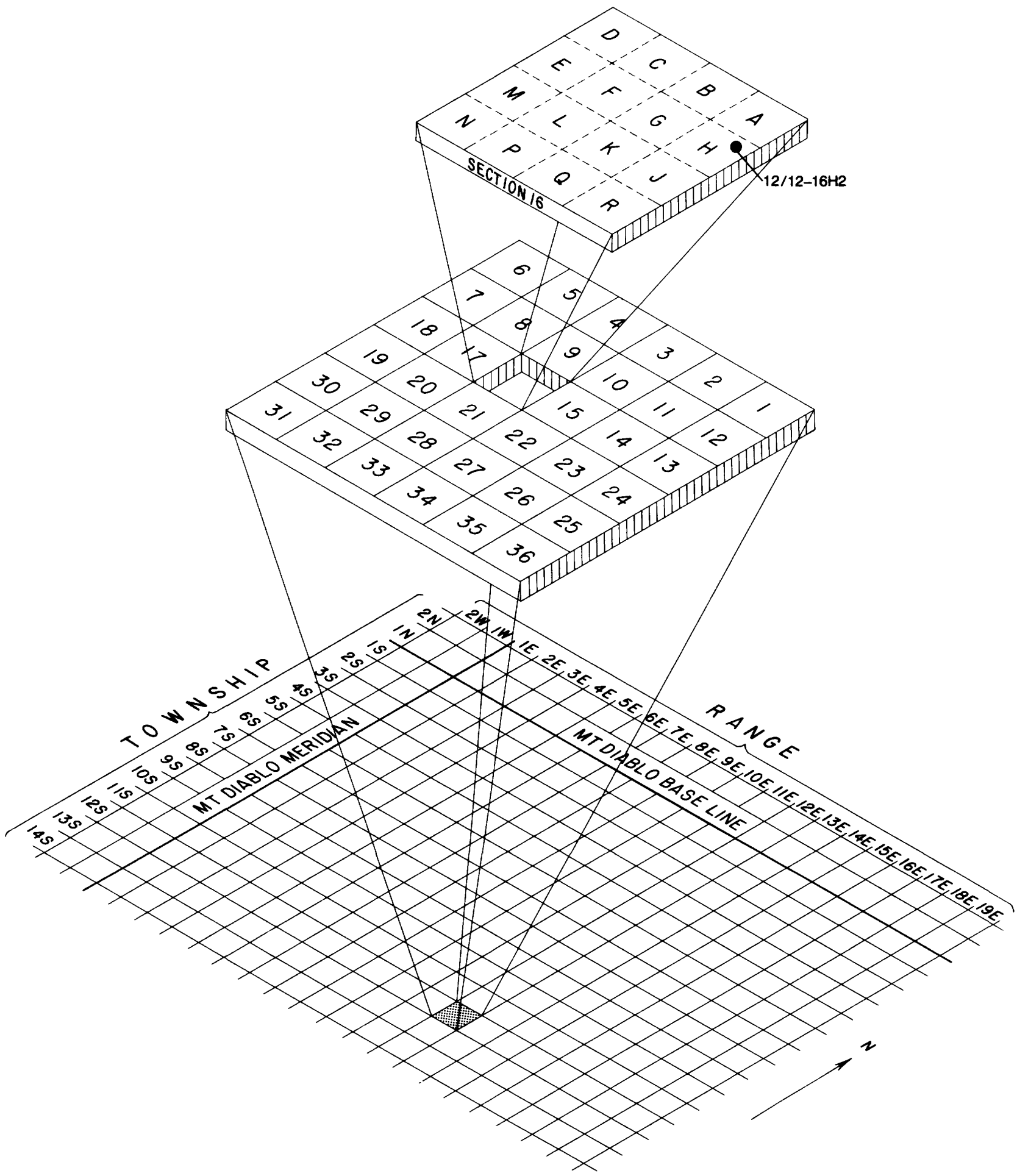

Figure 3.-Well-numbering system. 


\section{STATUS OF SUBSIDENCE AND WATER-LEVEL CHANGE}

LOS BANOS-KETTLEMAN CITY AREA

Land subsidence due to water-level decline in the Los Banos-Kettleman City area was reported in Geological Survey publications by Bull and Miller (1975), Bull (1975), and Bull and Poland (1975); a report by Poland and others (1975) updated and summarized subsidence in this area. Location of the area, $A$, is shown in figure 32.

Land subsidence due to hydrocompaction in the Los Banos-Kettleman City area was reported by Bull (1964a).

The hydrogeology of the ground-water reservoir in the Los Banos-Kettleman City area was described by Miller and others (1971).

Land subsidence in the Los Banos-Kettleman City area reached a maximum of $29 \mathrm{ft}$ in 1972 and $29.6 \mathrm{ft}$ in 1977. Figure 4 shows the historic subsidence in the Los Banos-Kettleman City area from 1926 to 1972, the last areawide leveling in the Los Banos-Kettleman City area. The maximum subsidence of $29 \mathrm{ft}$ occurred southwest of Mendota (within the 28-ft subsidence contour). Three major subsidence depressions, a large area south and west of Mendota, an area south and west of the town of Cantua Creek, and a large area in the vicinity of Huron, all show more than $20 \mathrm{ft}$ of subsidence. The California Aqueduct traverses all three of these major subsidence depressions. Additional leveling data are available in the area along the California Aqueduct and will be discussed later (pl. 1). The aqueduct profiles show substantial subsidence along the aqueduct during construction, and decreased subsidence after 1968 because of increasing importation of surface water, then increased subsidence during the drought years 1976-77.

As stated earlier, the unconfined to semiconfined water-bearing deposits above the principal confining bed are referred to as the upper water-bearing zone, and the confined system beneath the confining bed as the lower water-bearing zone. The upper water-bearing zone has a water table, and locally the water is unconfined. The most permeable aquifers in the Los Banos-Kettleman City area are in the upper water-bearing zone but are of limited extent. Ground water of the upper water-bearing zone generally contains high concentrations of calcium, magnesium, and sulfate, except near Fresno Slough (Bull and Miller, 1975).

The lower water-bearing zone is confined by the Corcoran Clay Member of the Tulare Formation except in the southwestern part of the Los Banos-Kettleman City area where the Corcoran Clay Member is absent and confinement is poor or lacking. Deposits forming the lower water-bearing zone aquifer system in the Los
Banos-Kettleman City area are locally less permeable than the deposits forming the semiconfined aquifer system of the upper zone. Before surface water was imported into the Los Banos-Kettleman City area via the California Aqueduct, at least 75-80 percent of the irrigation water pumped in the area was from the lower zone (Bull and Miller, 1975) because of the greater thickness of the lowerzone deposits and the generally poorer quality of the water in the upper zone.

Seven generalized water-level profiles for the lower water-bearing zone beneath the California Aqueduct from 1943 to 1976 in the Los Banos-Kettleman City area show the changes from the 1943 level (fig. 5 ; see fig. 36 for location). These profiles show the water levels declining from 1943 through 1967, then recovering to 1976 (using 1943 as a base). The water-level data on these profiles, when compared with the subsidence data on plate 1 , show the changing stresses that produce subsidence or rebound. These profiles were prepared using maps of the potentiometric surface of the lower water-bearing zone (figs. 7-14), constructed by the Geological Survey. The water-level contour maps were overlaid on the California Aqueduct alinement and elevations of the potentiometric surface were plotted at selected distances along the aqueduct alinement. Water-level changes at the selected distances were determined by subtracting the 1943 water-level elevation from the plotted elevation for the potentiometric surface for each of 7 years.

Figure 6 shows the location of subsidence profiles along and near the California Aqueduct, selected observation wells, nearby bench marks, and boundaries of the principal confining beds in the valley.

The generalized water-level contours on the potentiometric surface of the lower water-bearing zone at seven times from 1943-76 in the Los Banos-Kettleman City area are shown in figures 7-14. The water-level maps were constructed using the topographic elevations mapped in the 1920's; the continuing land subsidence was not subtracted from the water-surface elevation except on the 1974 map (fig. 13) where the 1926-72 subsidence (fig. 4) has been subtracted. Thus, the 1974 map shows the approximate true elevation of the water surface in wells tapping the lower zone.

After the California Aqueduct was completed and surface water became available in 1968 , many wells were abandoned, destroyed, or taken out of service for economic reasons. Representative water-level measurements became more difficult to obtain. Many of the casings of the older wells were broken due to compaction and compressive failure; some were cut off, capped or buried. The large recovery in artesian head in the lower water-bearing zone from 1967 to 1976 almost equalized water levels in the upper and lower water-bearing zones in some parts of the area, making it increasingly difficult 


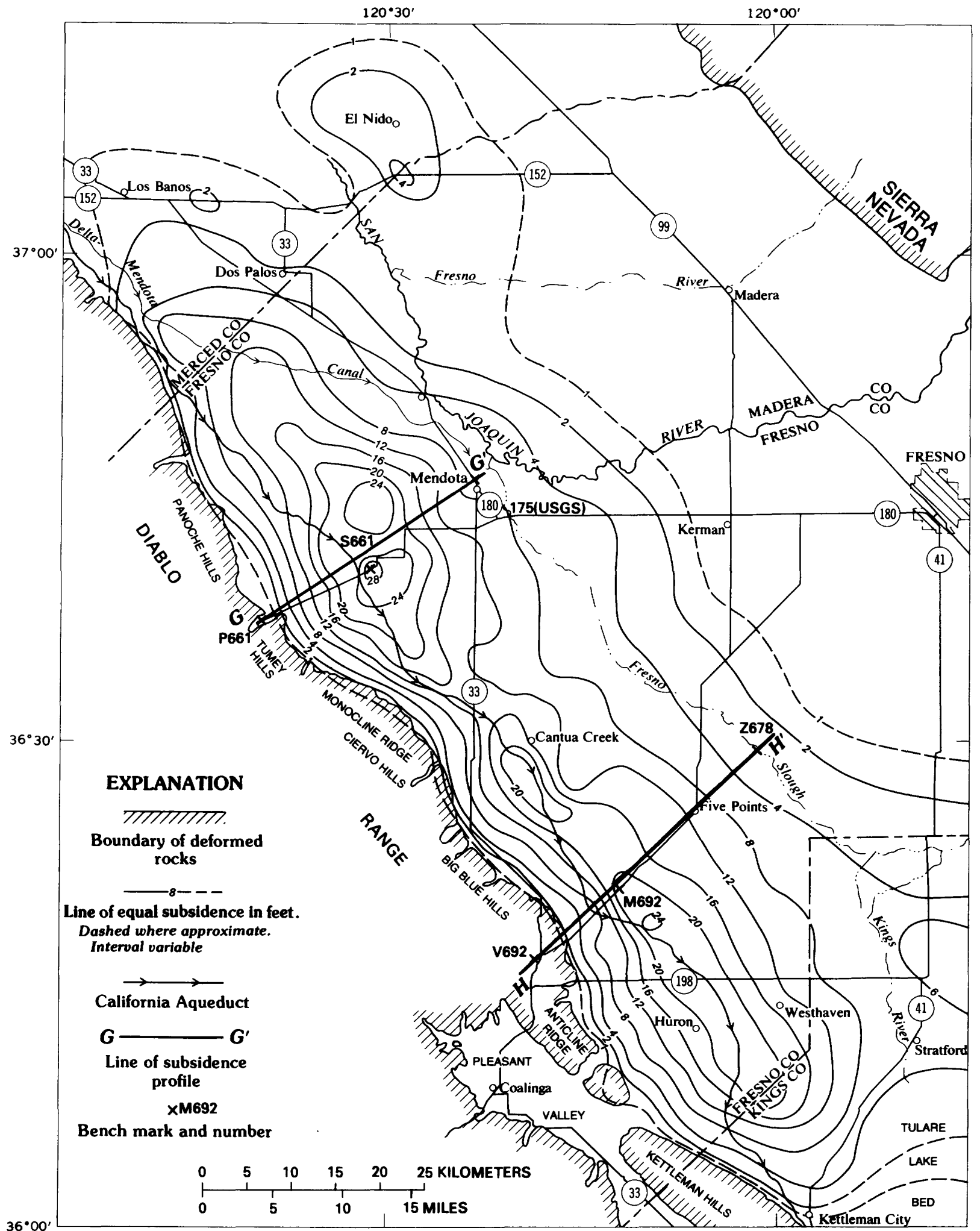

FIGURE 4.-Land subsidence, 1926-72, Los Banos-Kettleman City area. Base from U.S. Geological Survey, 1:250,000, Central Valley map, 1958. 


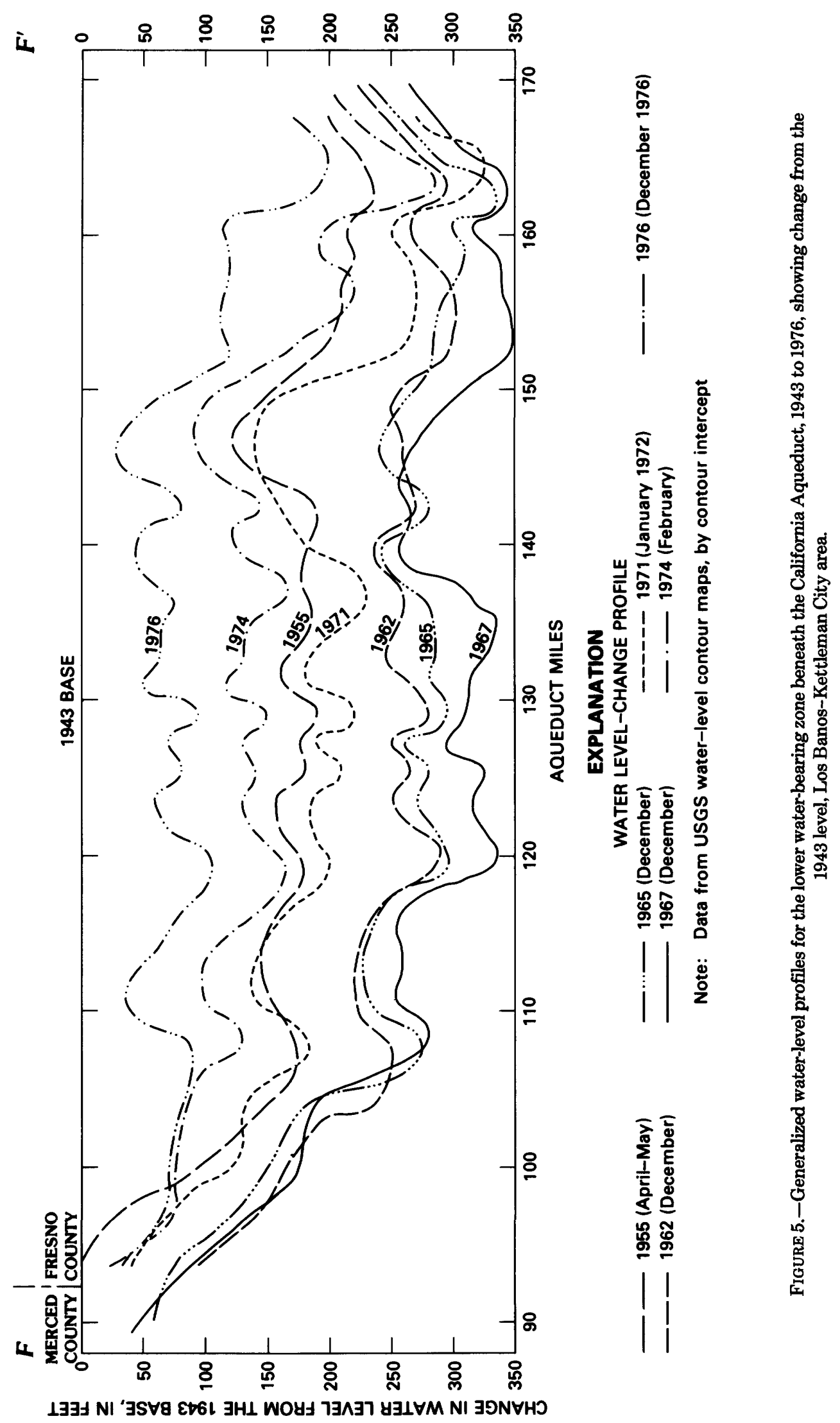


to construct an accurate water-level map for the lower water-bearing zone. During the 1976-77 drought, however, many new wells were drilled and many of the old wells were repaired and reactivated.

A map (fig. 15) of the water-level changes shows that water levels recovered as much as $200 \mathrm{ft}$ in the 6 years from 1967 to 1974.

The measured subsidence at bench mark S661 and artesian-head change in nearby wells, $10 \mathrm{mi}$ southwest of Mendota, from 1943 to 1977 is shown in figure 16 (see fig.

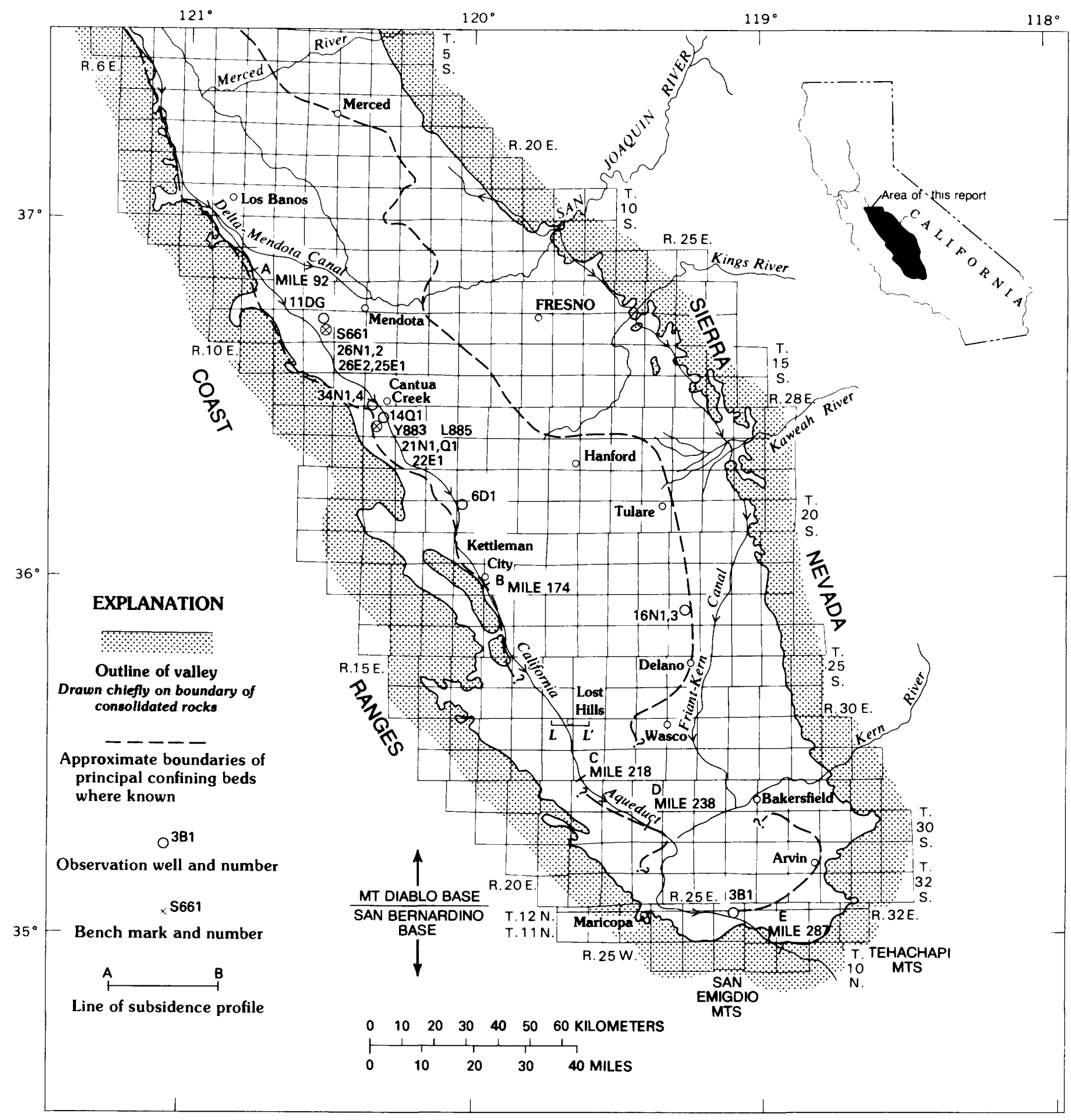

Figure 6.-Location of California Aqueduct, subsidence profiles, selected observation wells, nearby bench marks, and boundaries of principal confining beds. 


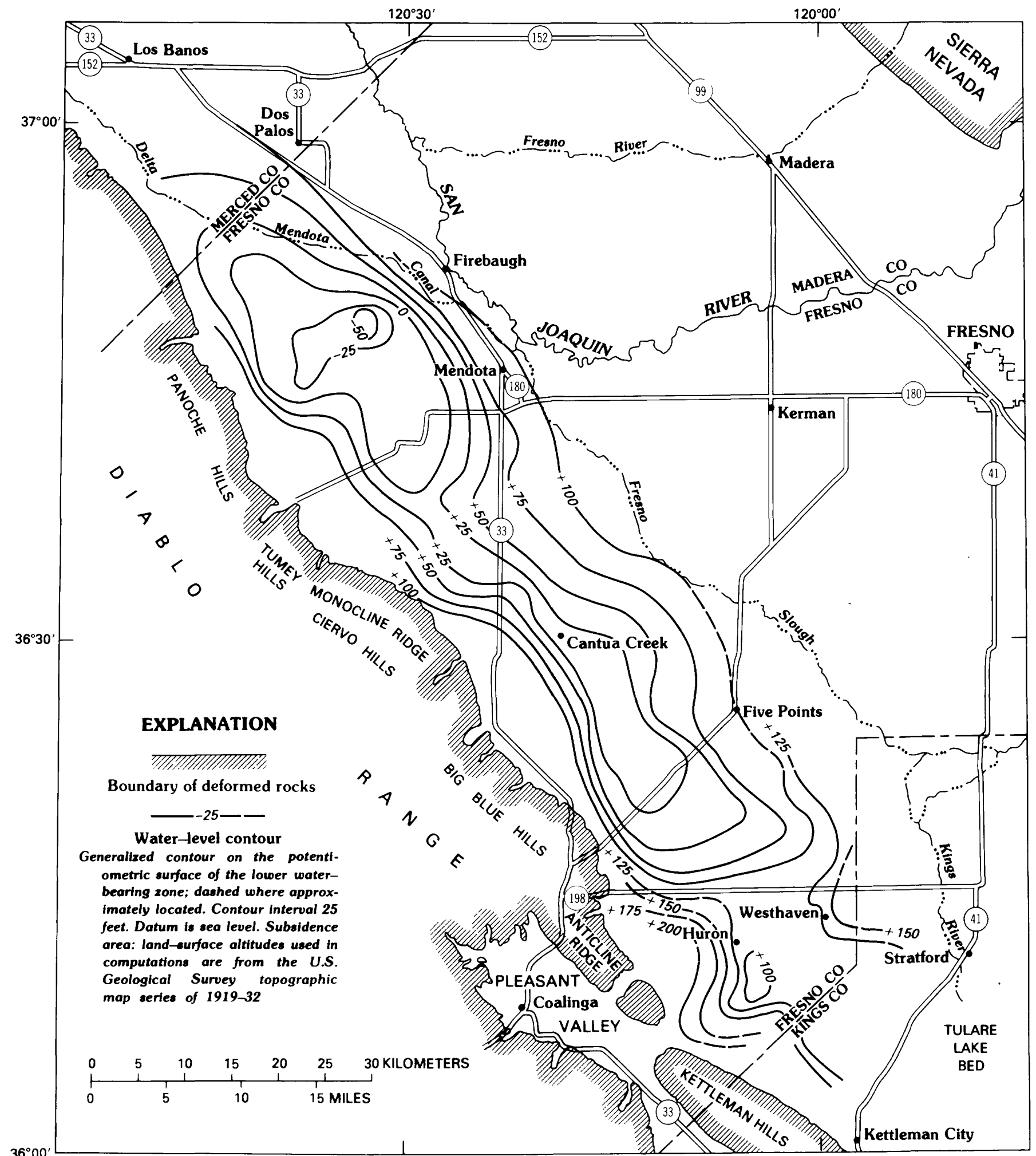

FIGURE 7.-Generalized water-level contours for the lower water-bearing zone, spring and summer 1943, in the Los Banos-Kettleman City area. Base from U.S. Geological Survey, 1:250,000, Central Valley map, 1958. 


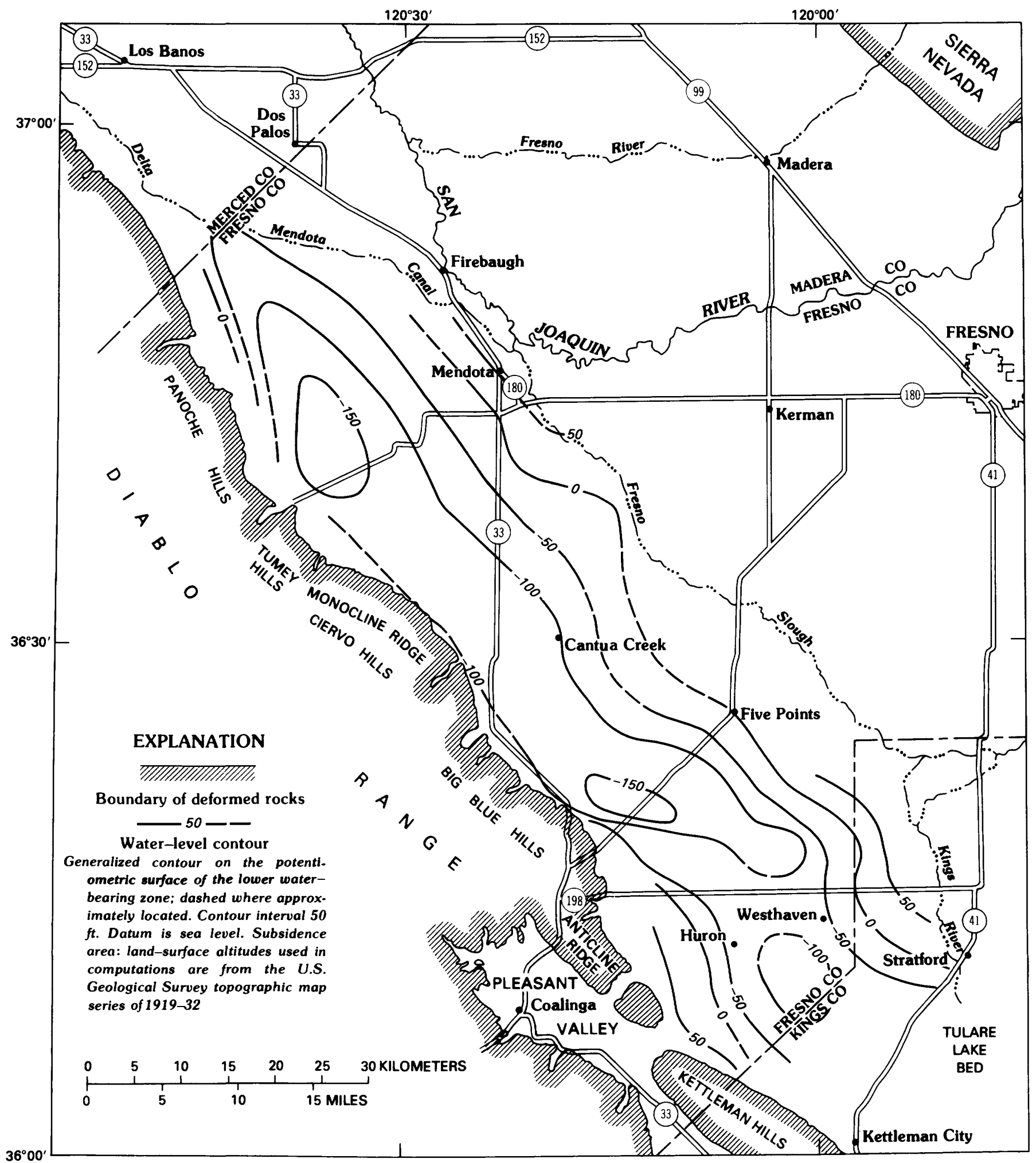

FIGURE 8.-Generalized water-level contours for the lower water-bearing zone for April-May 1955, in the Los Banos-Kettleman City area. Base from U.S. Geological Survey, 1:250,000, Central Valley map, 1958. 


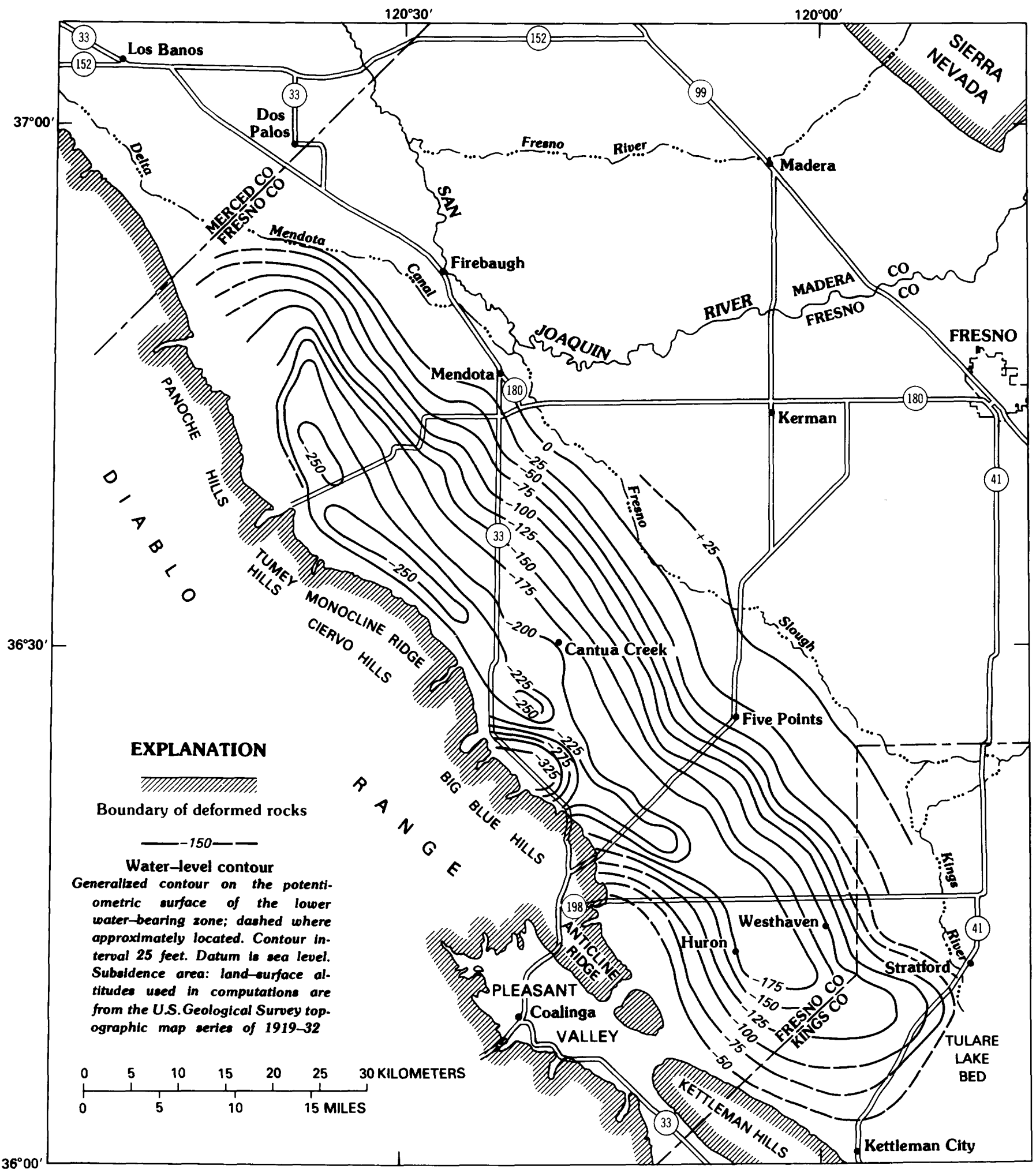

FIGURE 9.-Generalized water-level contours for the lower water-bearing zone, December 1962, in the Los Banos-Kettleman City area. Base from U.S. Geological Survey, 1:250,000, Central Valley map, 1958. 


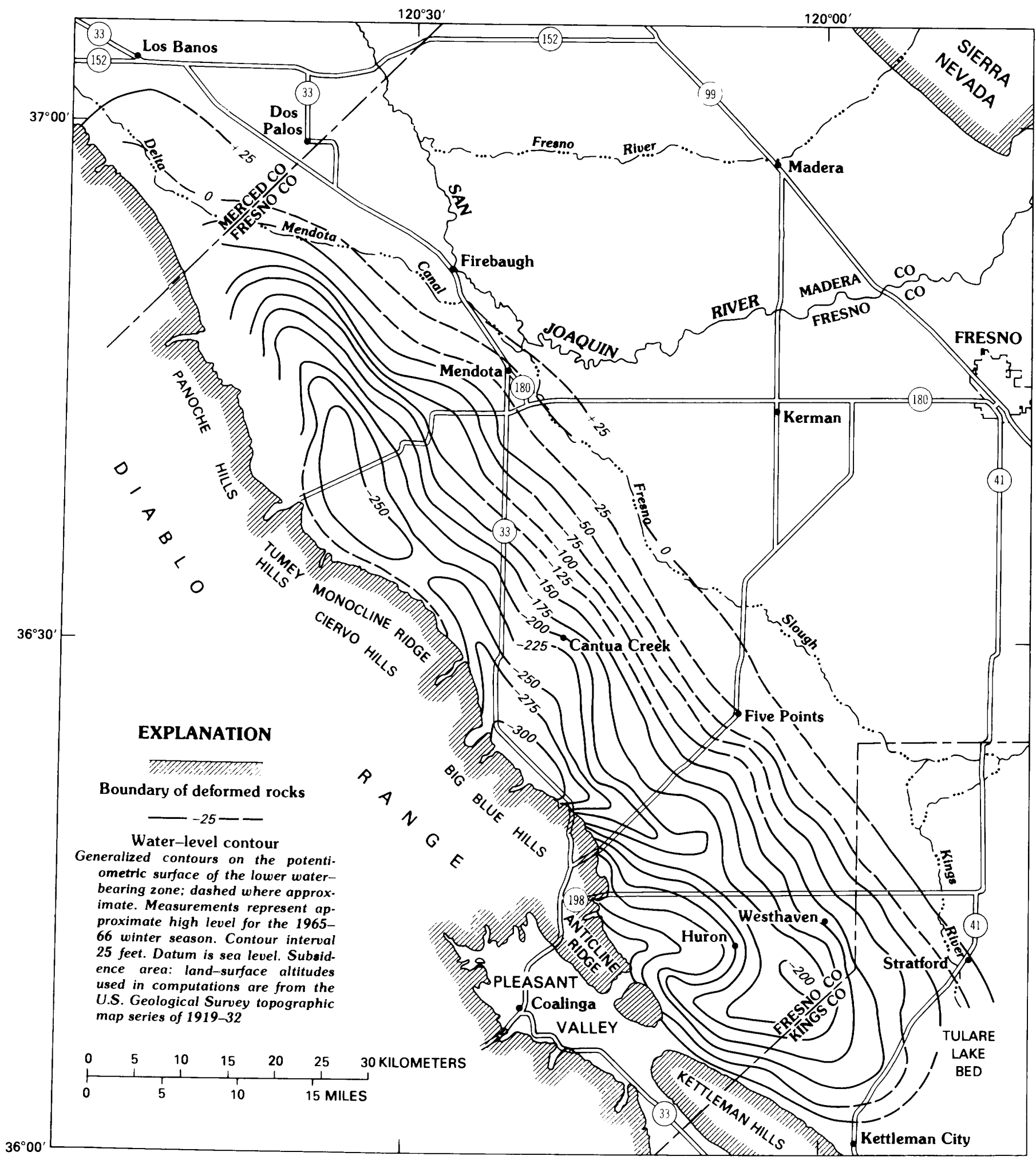

FIGURE 10.-Generalized water-level contours for the lower water-bearing zone, December 1965, in the Los Banos-Kettleman City area. Base from U.S. Geological Survey, 1:250,000, Central Valley map, 1958. 


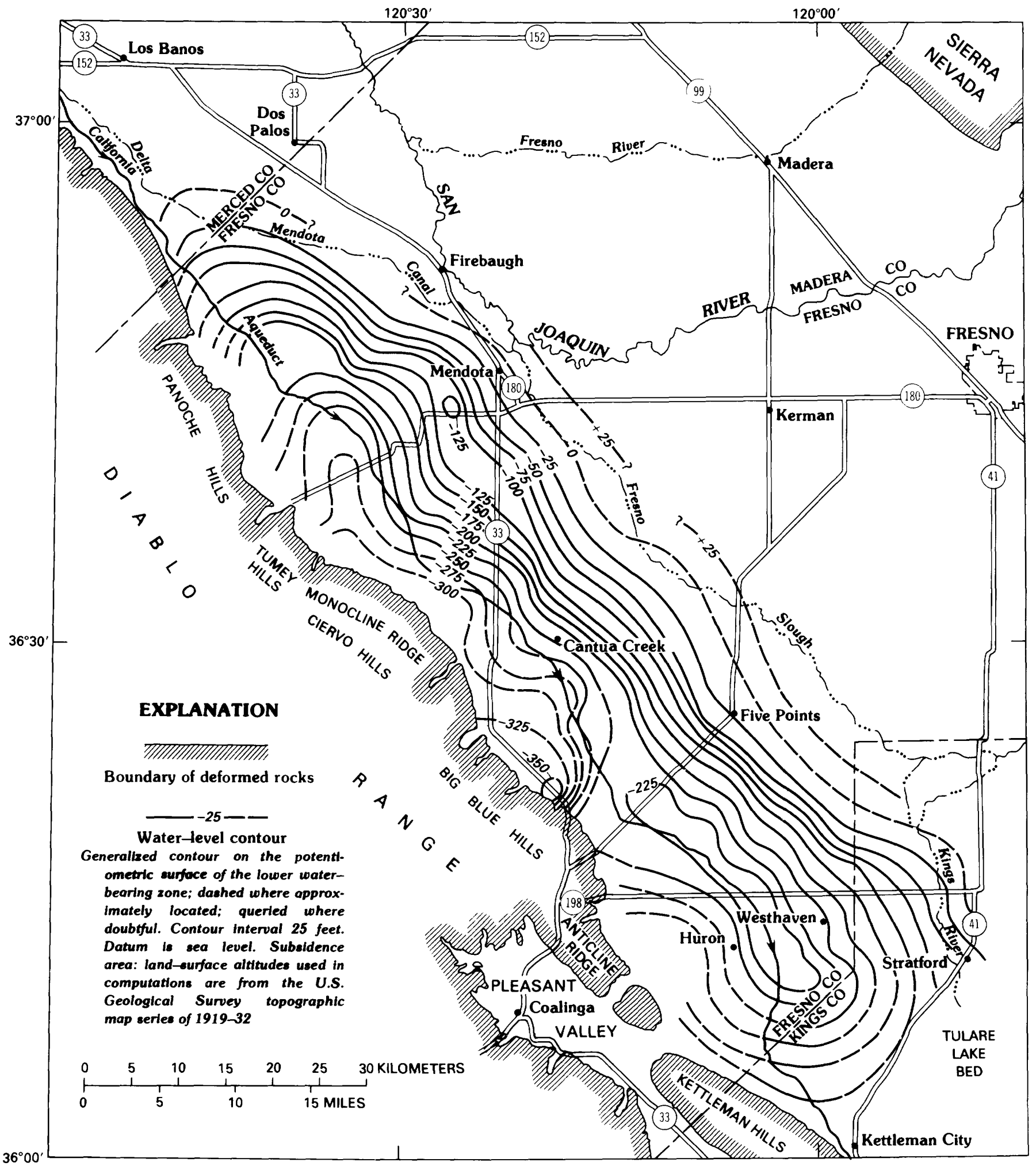

FIGURE 11.-Generalized water-level contours for the lower water-bearing zone, December 1967, in the Los Banos-Kettleman City area. Base from U.S. Geological Survey, 1:250,000, Central Valley map, 1958. 


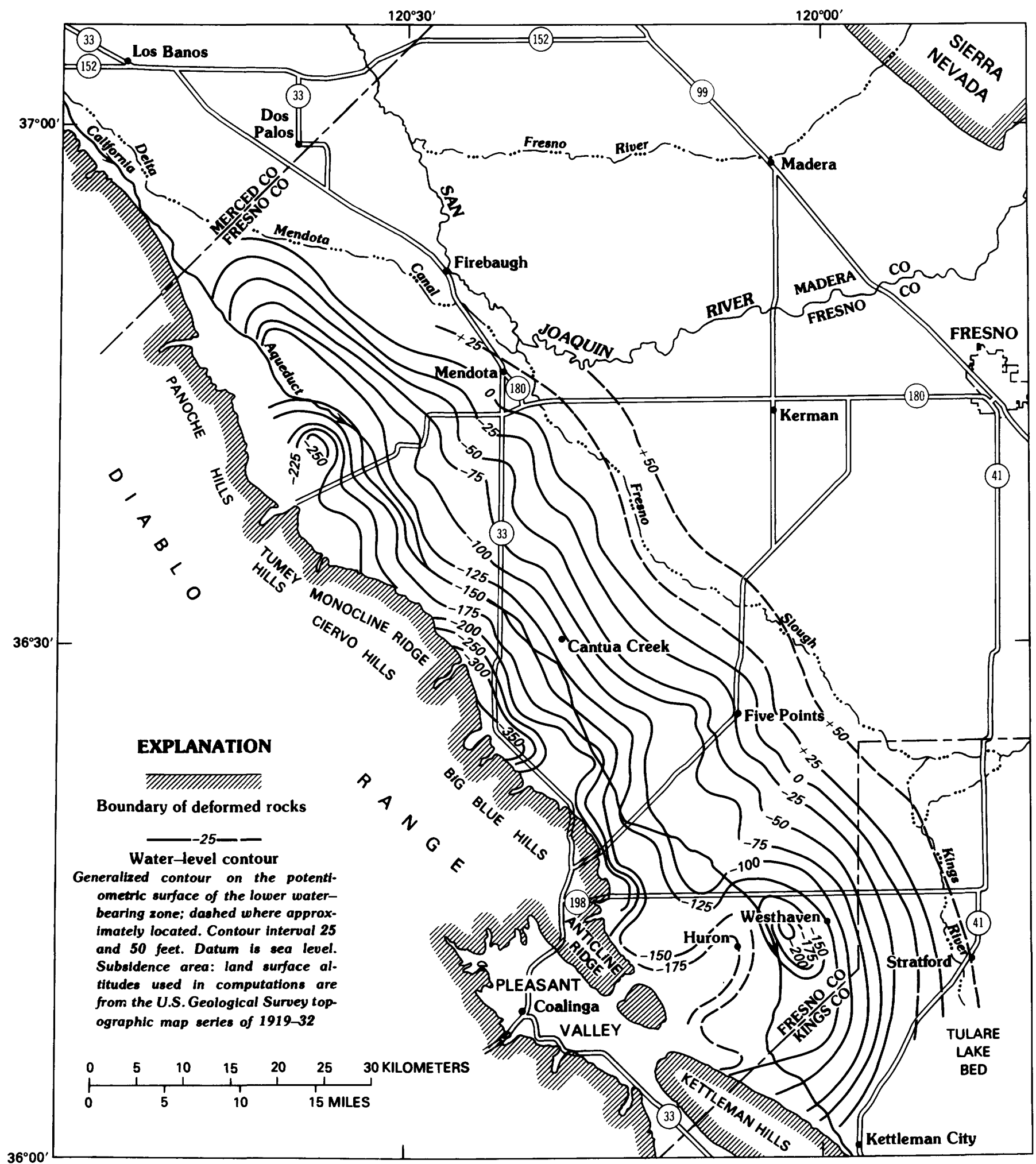

FIGURE 12.-Generalized water-level contours for the lower water-bearing zone, January 1972, in the Los Banos-Kettleman City area. Base from U.S. Geological Survey, 1:250,000, Central Valley map, 1958. 


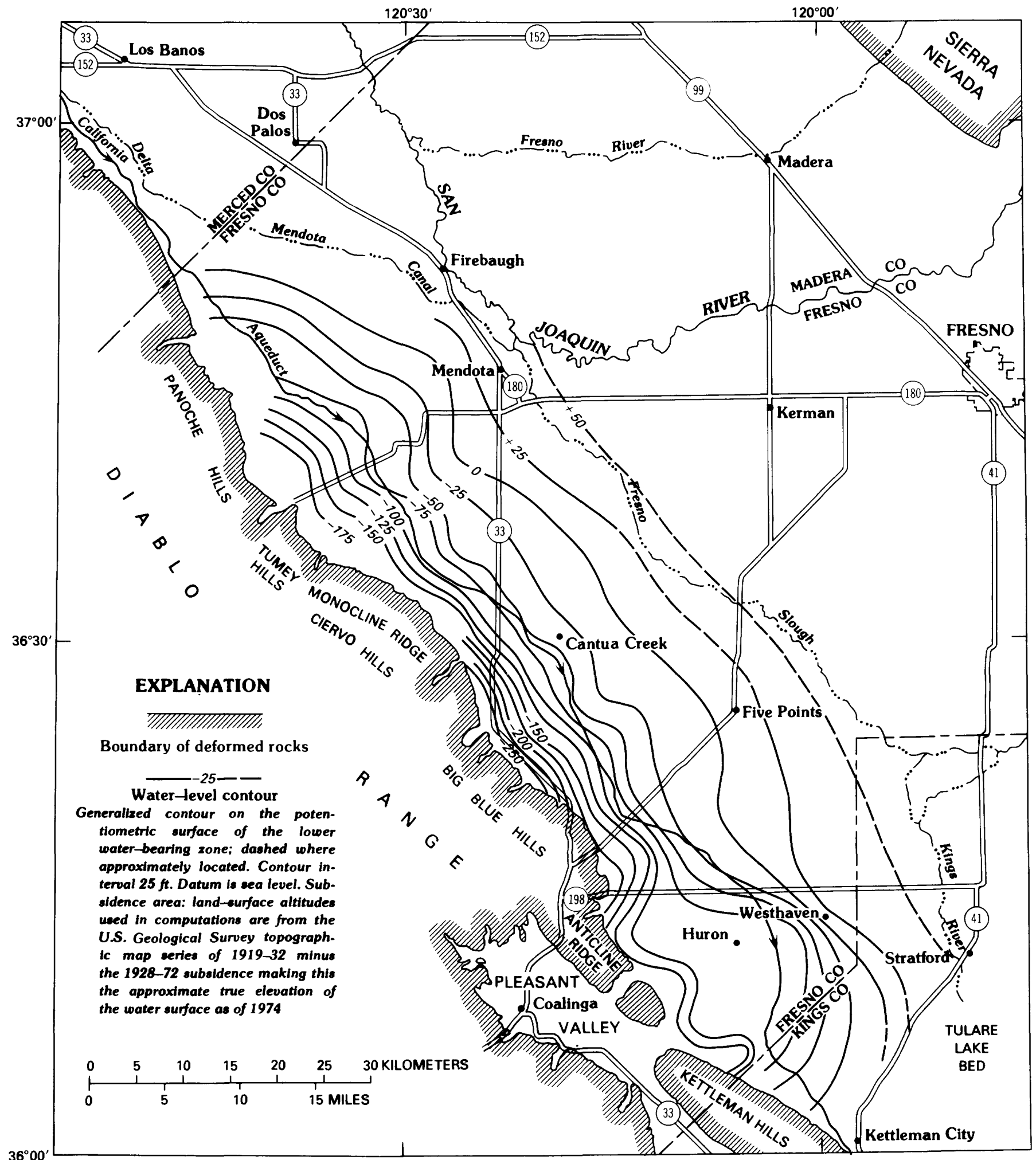

FIGURE 13.-Generalized water-level contours for the lower water-bearing zone, February 1974, in the Los Banos-Kettleman City area. Base from U.S. Geological Survey, 1:250,000, Central Valley map, 1958. 


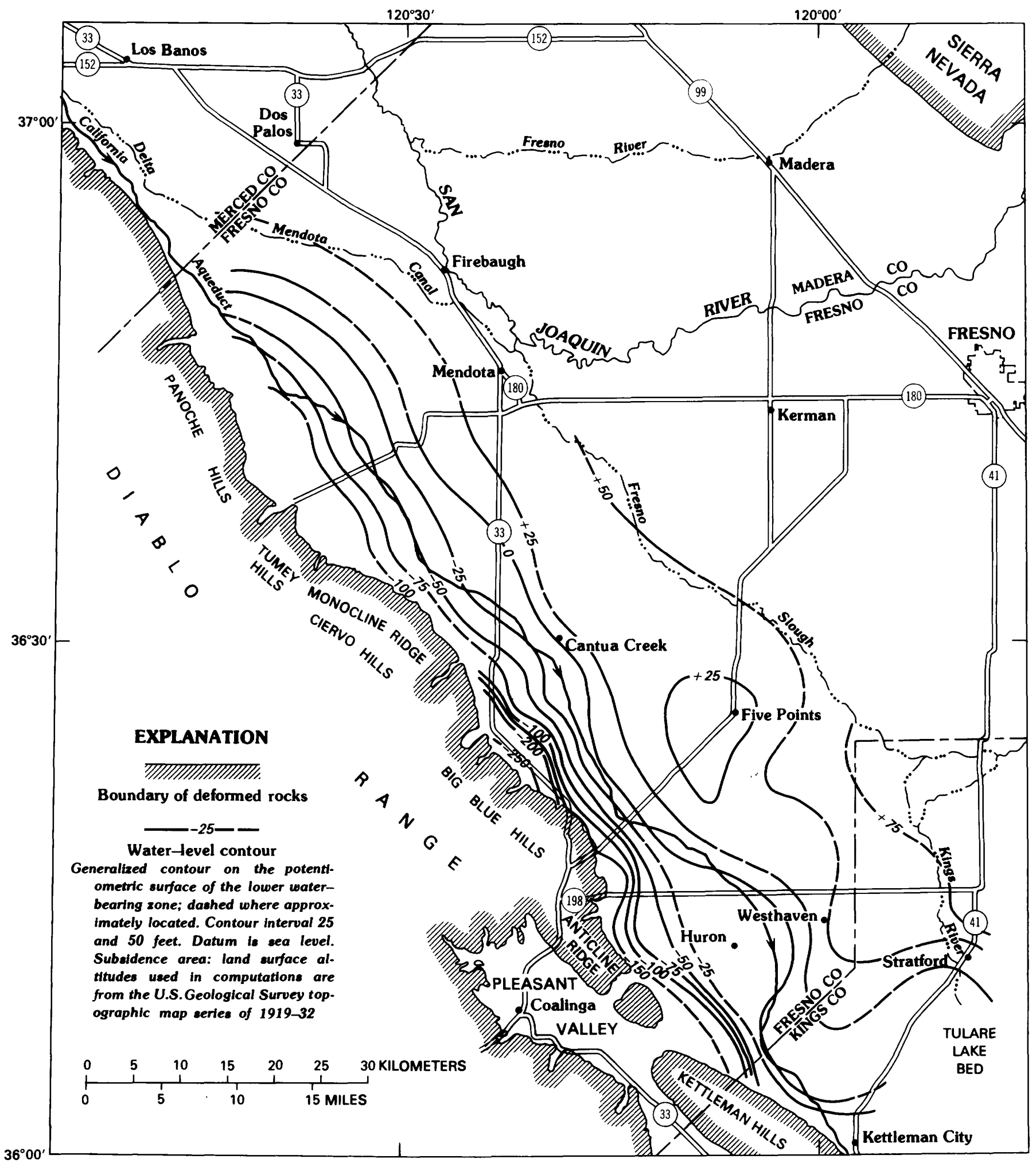

FIGURE 14.-Generalized water-level contours for the lower water-bearing zone, December 1976, in the Los Banos-Kettleman City area. Base from U.S. Geological Survey, 1:250,000, Central Valley map, 1958. 


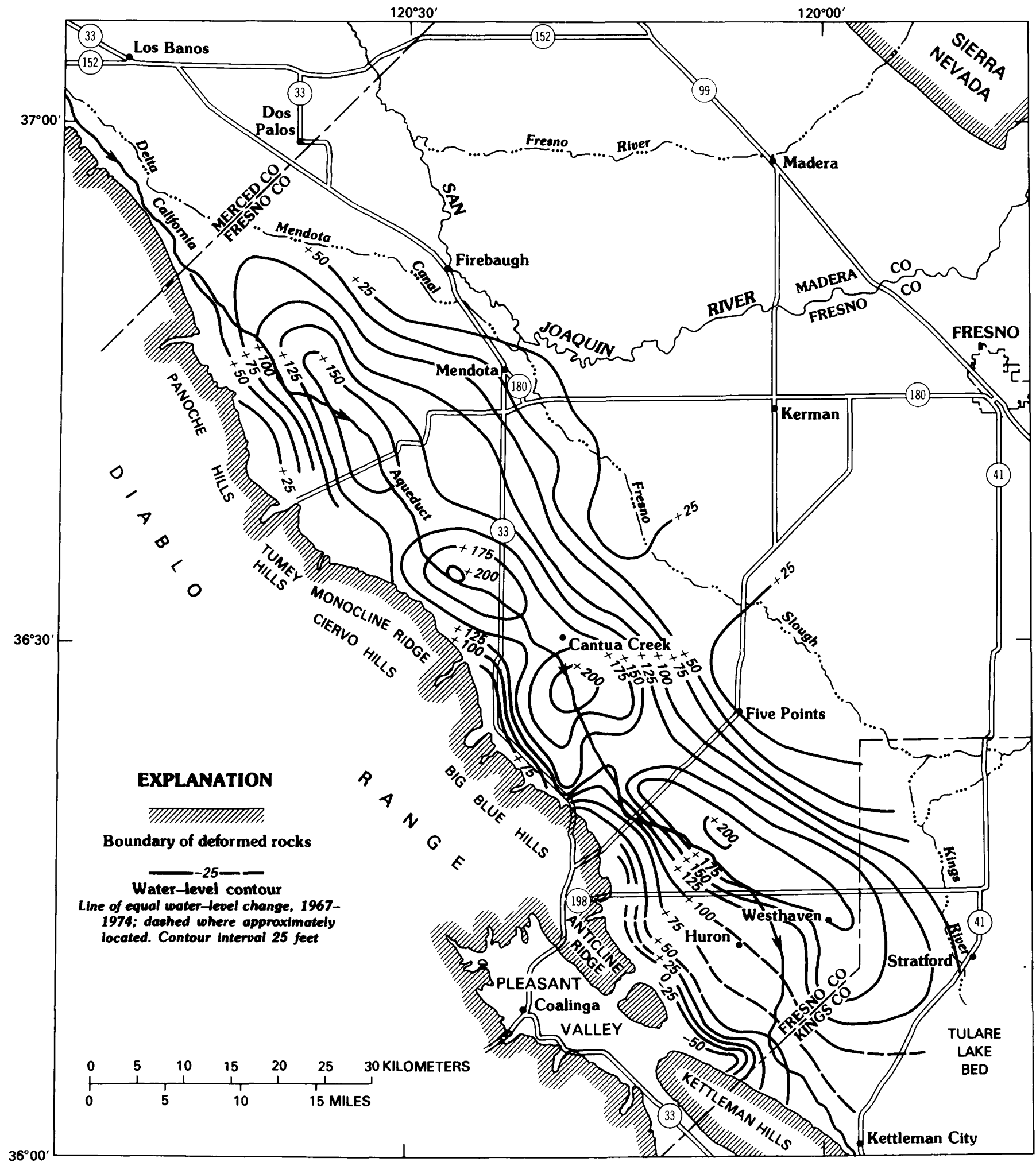

FIGURE 15.-Generalized water-level change for the lower water-bearing zone, December 1967 to February 1974, in the Los Banos-Kettleman City area. Base from U.S. Geological Survey, 1:250,000, Central Valley map, 1958. 
6 for location). Measured change of $27.13 \mathrm{ft}$ at this bench mark since 1943, plus $2.5 \mathrm{ft}$ of topographic change from the 1920's through 1943, make this the locus of maximum known subsidence in the San Joaquin Valley. The artesian-head decline through 1967-68 illustrates the increasing stress causing the subsidence. As the artesian head recovered, subsidence rates became progressively lower. The bar graph of the subsidence rate clearly shows the effect of the importation of surface water in the late 1960 's and 1970's. The yearly subsidence rate in 1969-72 was only about one-third that of 1966-69. During the drought years of 1976-77, subsidence rates averaged 0.12 $\mathrm{ft}$ per year; at this site the water-level drawdown of $120 \mathrm{ft}$ in 1977 was not sufficient to increase the rate of subsidence.

The magnitude of subsidence at this site, $9 \mathrm{~m}$, from 1925 to 1977 is shown in figure 16. The photograph, taken in 1979 by the U.S. Geological Survey, shows the approximate position of land surface in 1925, 1955, and 1977.

The artesian head and the rates of subsidence (fig. 17) near the town of Cantua Creek (see fig. 6 for location) changed remarkably during the years from the 1950's to the 1960's. When surface water was imported to replace pumpage from wells, water levels rose and the rate of subsidence decreased markedly in the early 1970's. The rate of subsidence in 1976-77 was nearly double that of 1973-75. Evidently, drawdown was substantial in 1977, but, unfortunately, the water level in well N1 was not measured in 1977.

The historical subsidence southwest of Mendota and along Five Points Road from 1943 to 1977-78 is shown in the two transverse subsidence profiles (figs. 18 and 19; see fig. 4 for locations). Water-level decline along both profiles was the sole cause of the subsidence (Poland and others, 1975). Profile G-G' (fig. 18), which extends from the foothills of the Diablo Range through Mendota, passes close to the site of maximum subsidence (bench mark S661). Profile $\mathrm{H}-\mathrm{H}^{\prime}$ (fig. 19), which extends northeastward along the Five Points Road from Anticline Ridge to Fresno Slough, passes close to bench mark M692, the site
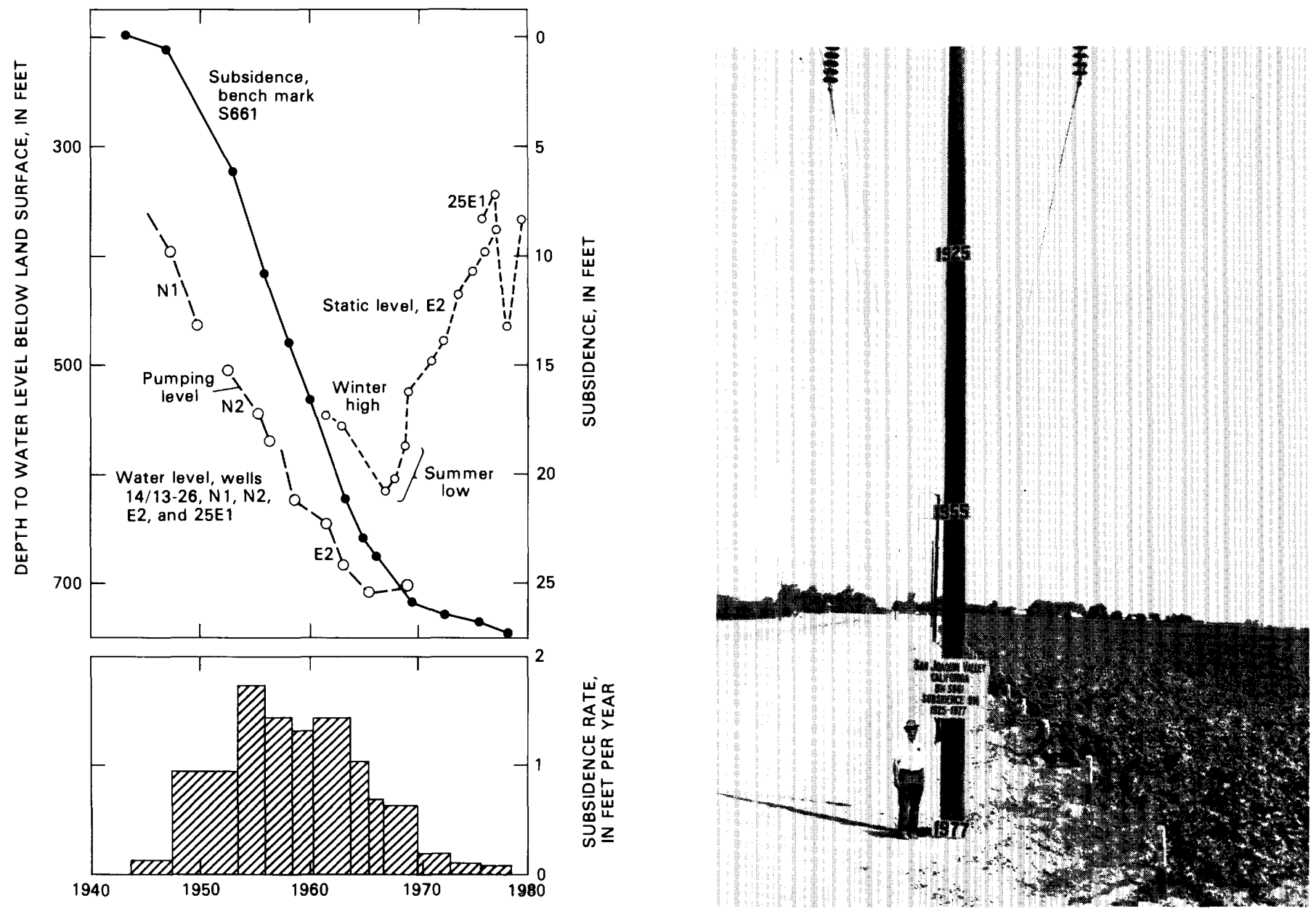

FIGURE 16.-Subsidence and artesian-head change, 10 miles southwest of Mendota, and photograph illustrating magnitude of subsidence at this site. Joseph Poland of the U.S. Geological Survey is pictured standing by the powerpole. 
of maximum subsidence on this profile, $21.2 \mathrm{ft}$, from 1943 to 1972 . This bench mark was not leveled in 1975 or 1977-78. Both profiles show subsidence during nine periods since 1943 and two partial relevelings in 1975 and 1977-78 (California Aqueduct leveling, 1977-78), using the 1943 control as a horizontal reference base. The pro- files show decreasing subsidence in the 1970's as more water was imported into the Los Banos-Kettleman City area.

The long-term trend of water levels in the confined aquifer system near the town of Cantua Creek from 1905 to 1964 and the seasonal high- and low-water levels at the

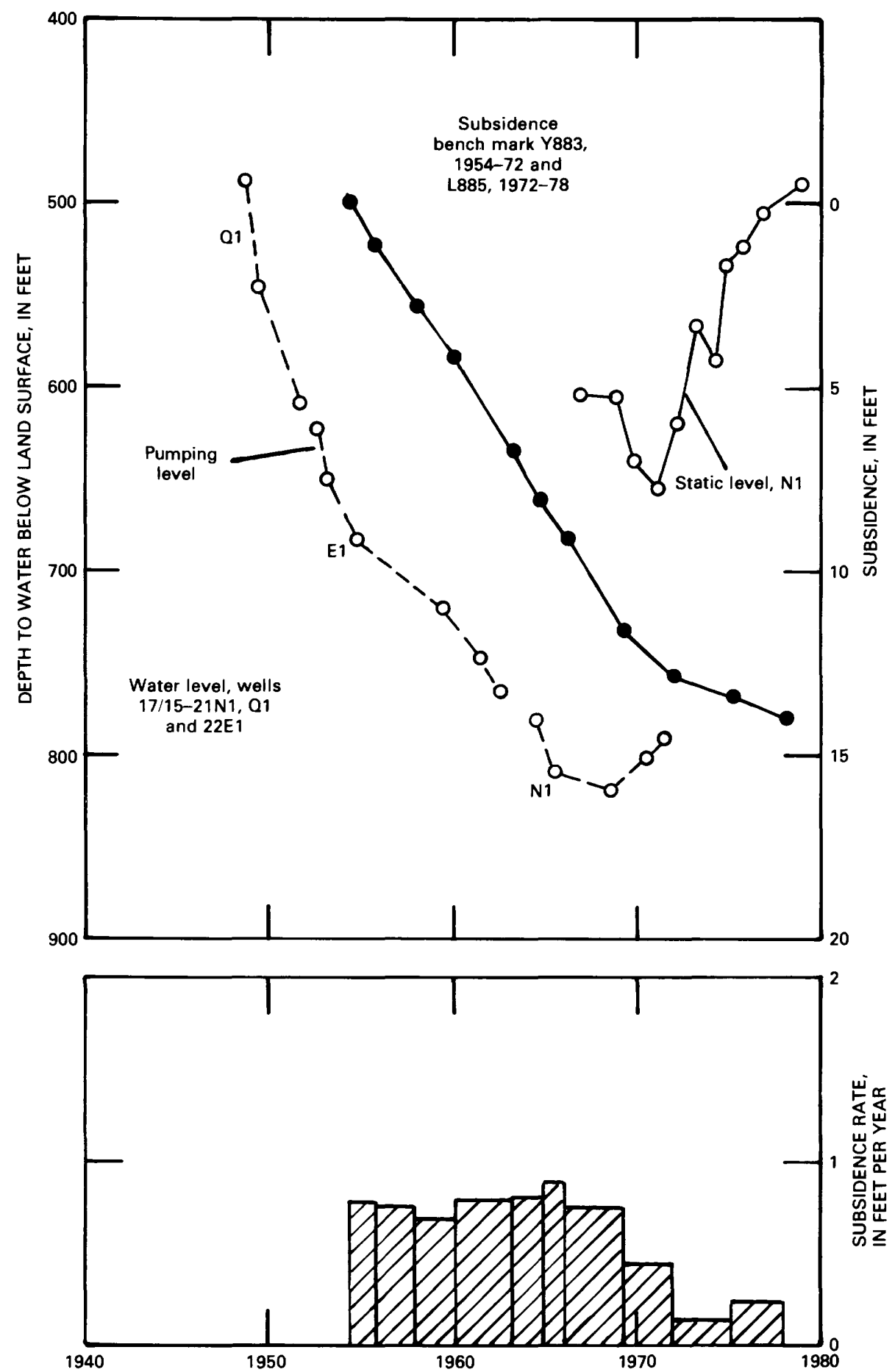

Figure 17.-Subsidence and artesian-head change near Cantua Creek. 
same location in observation well 16/15-34N4 for 1961-80 are shown in figure 20 (see fig. 6 for location). Irrigation wells in this area pump principally from the confined aquifer system, and observation well $16 / 15-34 \mathrm{~N} 4$ is perforated in the 1,052- to 1,132-ft depth range in the confined system. This site is in the trough of maximum subsidence about $20 \mathrm{mi}$ south of Mendota (fig. 4). The rate of decline accelerated from 1905 to 1960; water levels declined nearly $500 \mathrm{ft}$. In the early 1960's, the seasonal low levels in the confined aquifer system started dipping below the base of the clay confining layer. These seasonal lows had a marked effect on the storage characteristics of the aquifer system. With little or no change in pumping pattern, water levels declined very little from 1960 to 1968 when canal imports caused an abrupt decrease of ground-water pumpage and water-level recovery began. From 1968 to 1976 water levels recovered rapidly about $250 \mathrm{ft}$, mostly because of reduced pumping rates. This overall trend is rather typical of the heavily pumped areas of the western and southern parts of the valley, but the drawdown below the base of confinement is typical of only a few of the most heavily pumped areas. The unwatering below the base of the confining layer indicates a condition that could prevail in much of the valley if overdraft continued (Bull and Miller, 1975, fig. 34).
At the extensometer site 16/15-34N1 near Cantua Creek, there was an abrupt water-level recovery in well $16 / 15-34 \mathrm{~N} 4$ following the importation of canal water to the area in 1968, and a corresponding gradual cessation of compaction (fig. 21; see fig. 6 for location). Water-level data are from the same site as in figure 20 . Water levels recovered until the drought years of 1976-77, then when the surface-water deliveries stopped, the water levels were drawn down by intensive pumping of ground water and the compaction rate for 1977 increased to about that of 1970. The extensometer measured a net compaction of $0.42 \mathrm{ft}$ in the drought year 1977. In 1978 when surface water was again available, water levels recovered to predrought levels, and the extensometer measured a net expansion of $0.06 \mathrm{ft}$. The extensometer measured $0.01 \mathrm{ft}$ of compaction in 1979.

At three other extensometer sites in the Los Banos-Kettleman City area-southwest of Mendota (fig. 22), south of the town of Cantua Creek (fig. 23), and northeast of Huron (fig. 24) (see fig. 6 for location)-a similar trend of water-level recovery and decrease in measured compaction was recorded, followed by an abrupt water-level decline and renewed compaction during the 1977 drought. All four figures (figs. 21-24) show comparable records of measured compaction in response to change in

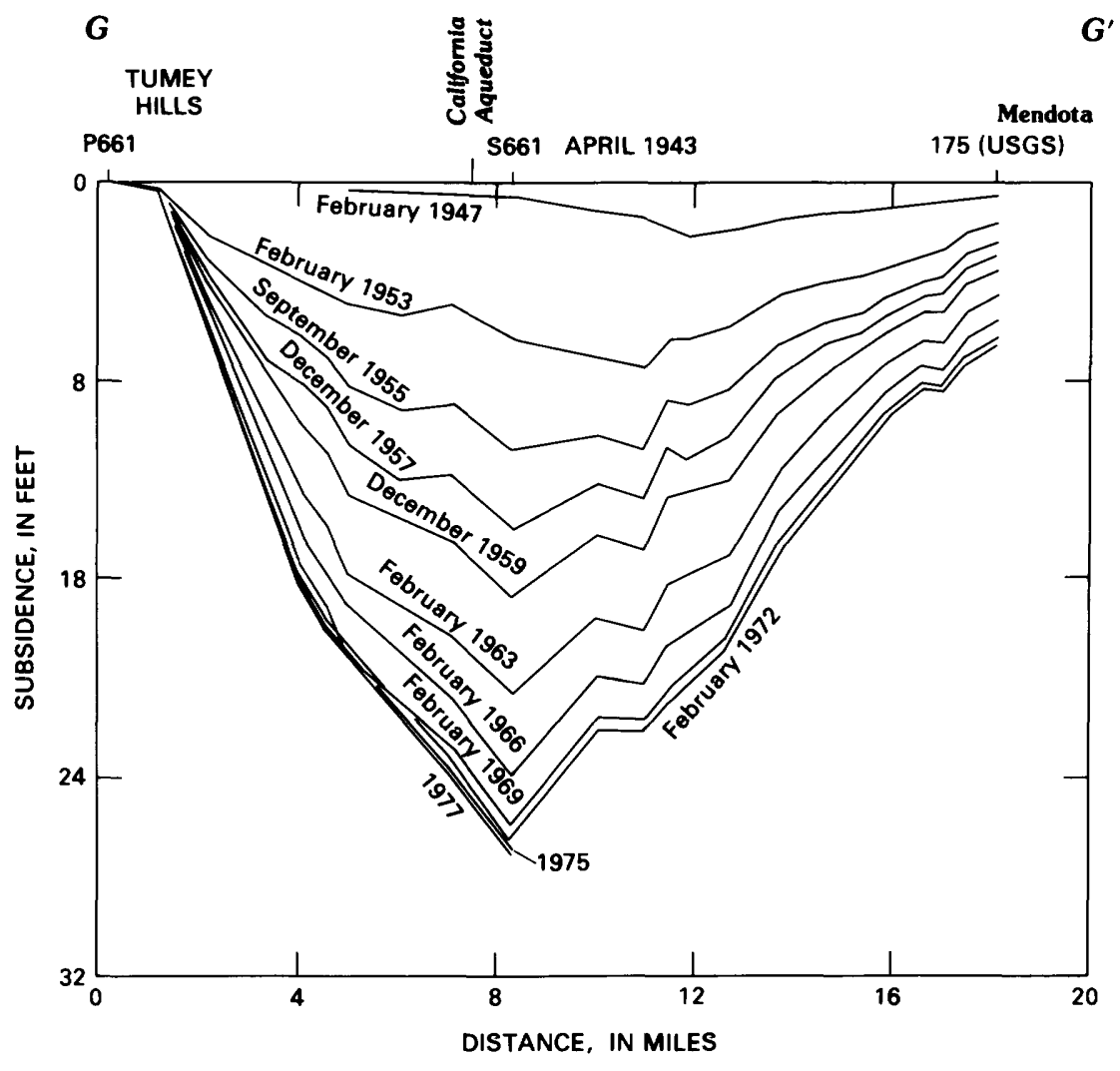

FigURE 18.-Profiles of subsidence, 1943-77, Tumey Hills to Mendota. 
artesian head in the lower water-bearing zone. Extensometer well 14/13-11D6 (fig. 22) measured a net compaction of $0.18 \mathrm{ft}$ in the drought year 1977, $0.07 \mathrm{ft}$ expansion in 1978, and $0.01 \mathrm{ft}$ expansion in 1979. Extensometer well 17/15$14 \mathrm{Q} 1$ (fig. 23) measured a net compaction of $0.54 \mathrm{ft}$ in the drought year $1977,0.20 \mathrm{ft}$ expansion in 1978, and no compaction or expansion in 1979. This site is subject to winter flooding and was flooded in 1978 , therefore, the record in 1977 and 1978 is questionable. Extensometer well 20/ 18-6D1 (fig. 24) measured a net compaction of $0.19 \mathrm{ft}$ in the drought year 1977, $0.09 \mathrm{ft}$ expansion in 1978, and 0.02 $\mathrm{ft}$ of compaction in 1979. This extensometer supplies only a partial measurement of the total compaction of the aquifer system; the extensometer depth is $867 \mathrm{ft}$ and irriga- tion wells are much deeper in this area. This well is located within $100 \mathrm{ft}$ of the California Aqueduct and is strongly influenced by pumping of an irrigation well 150 $\mathrm{ft}$ to the north, which explains why the seasonal drawdown in well $6 \mathrm{D} 1$ was an astonishing $250 \mathrm{ft}$ in the drought year 1977.

\section{TULARE-WASCO AREA}

Land subsidence in the Tulare-Wasco area was reported by Lofgren and Klausing (1969). Poland and others (1975) updated and summarized the subsidence in this area. Location of the area, $B$, is shown on figure 32 .

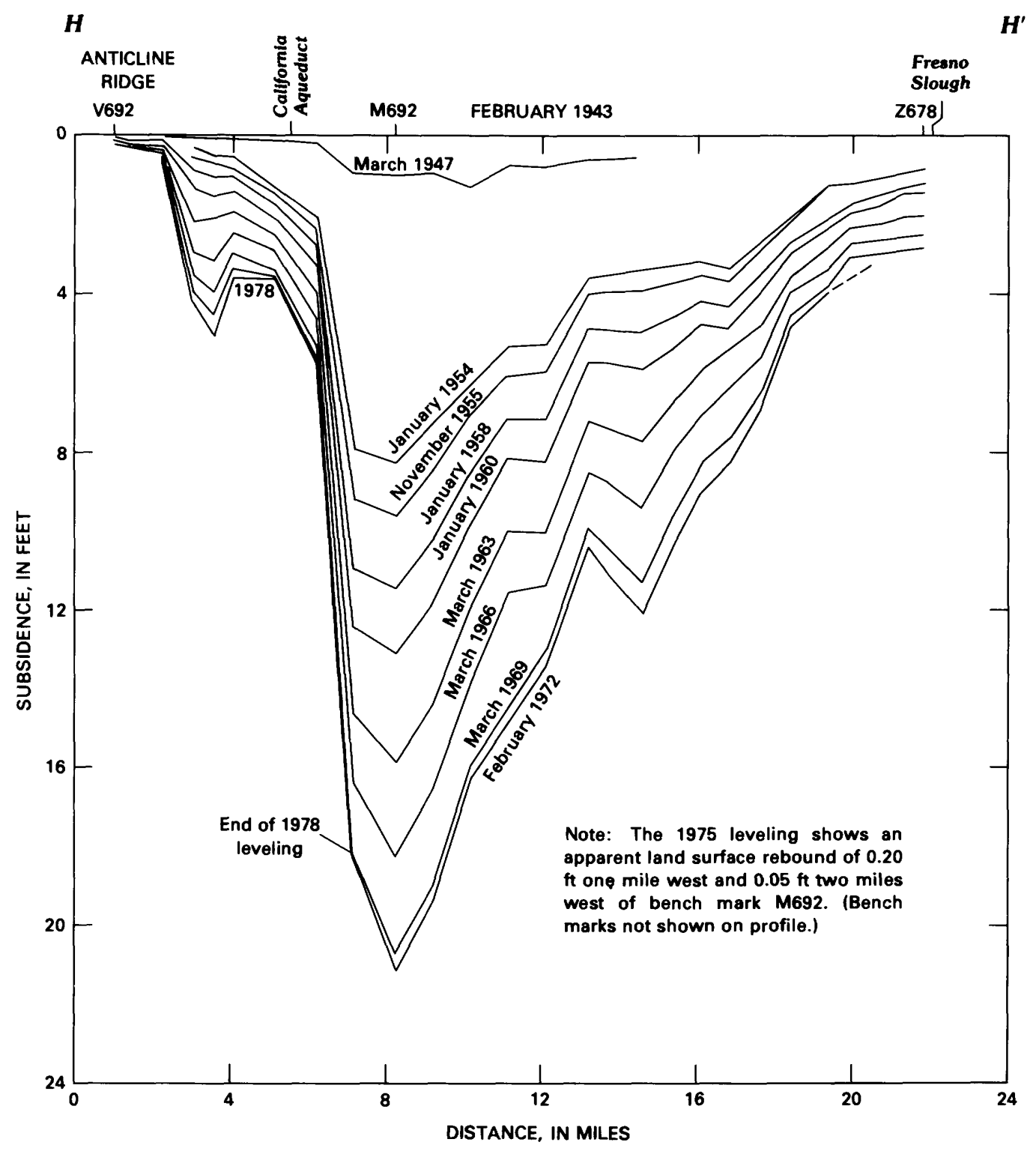

FIGURE 19.-Profiles of subsidence, 1943-78, Anticline Ridge to Fresno Slough. 


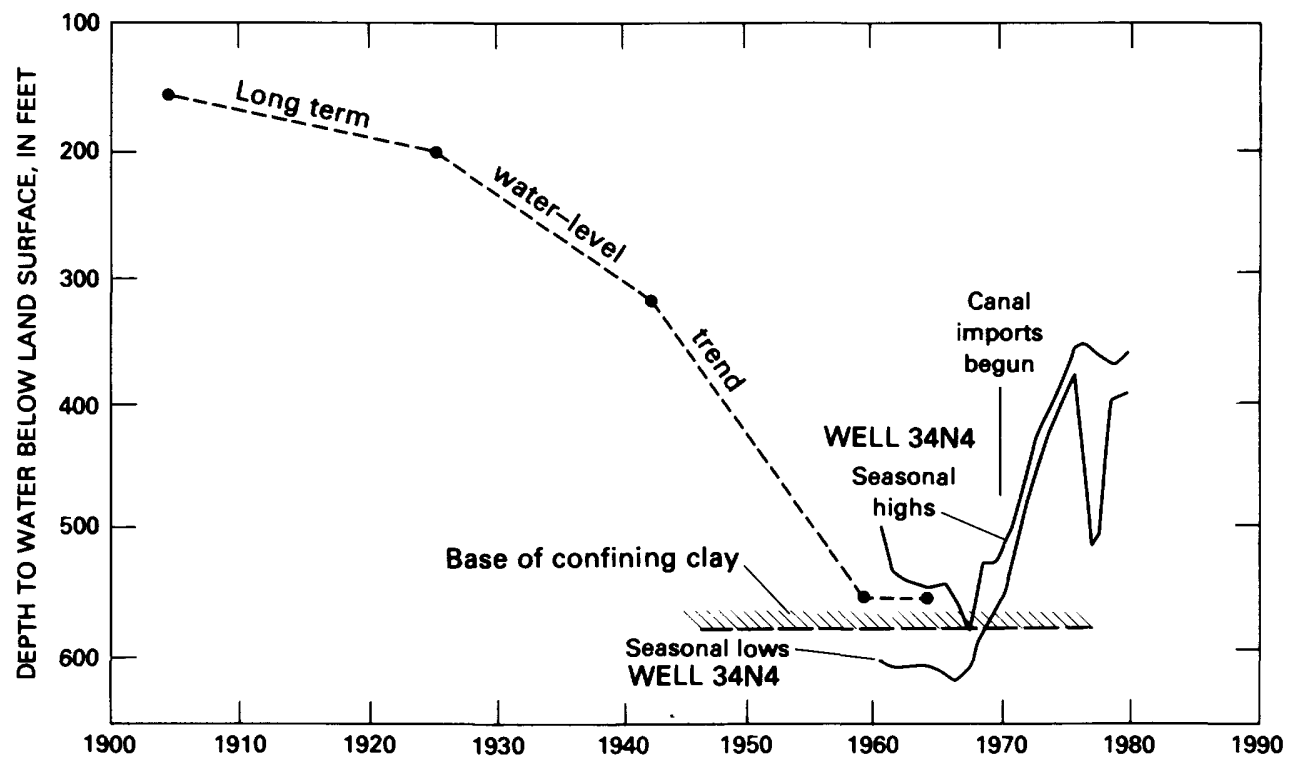

FIGURE 20.-Long-term trend of water levels near the town of Cantua Creek, and seasonal high- and lowlevels in observation well 16/15-34N4 since 1960.

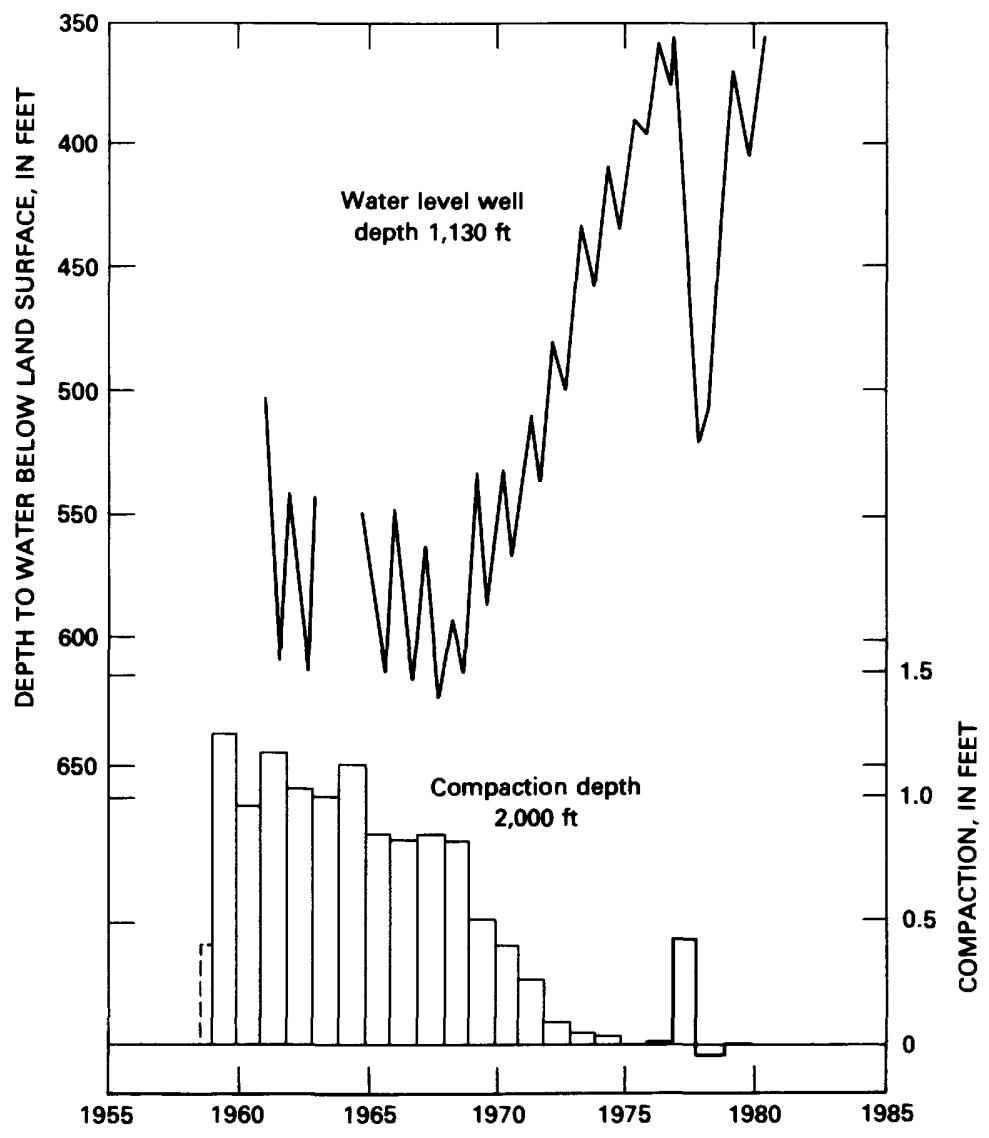

FIGURE 21.-Seasonal fluctuations of water level in well 16/15-34N4 and measured compaction in observation well 16/15-34N1 near Cantua Creek. 


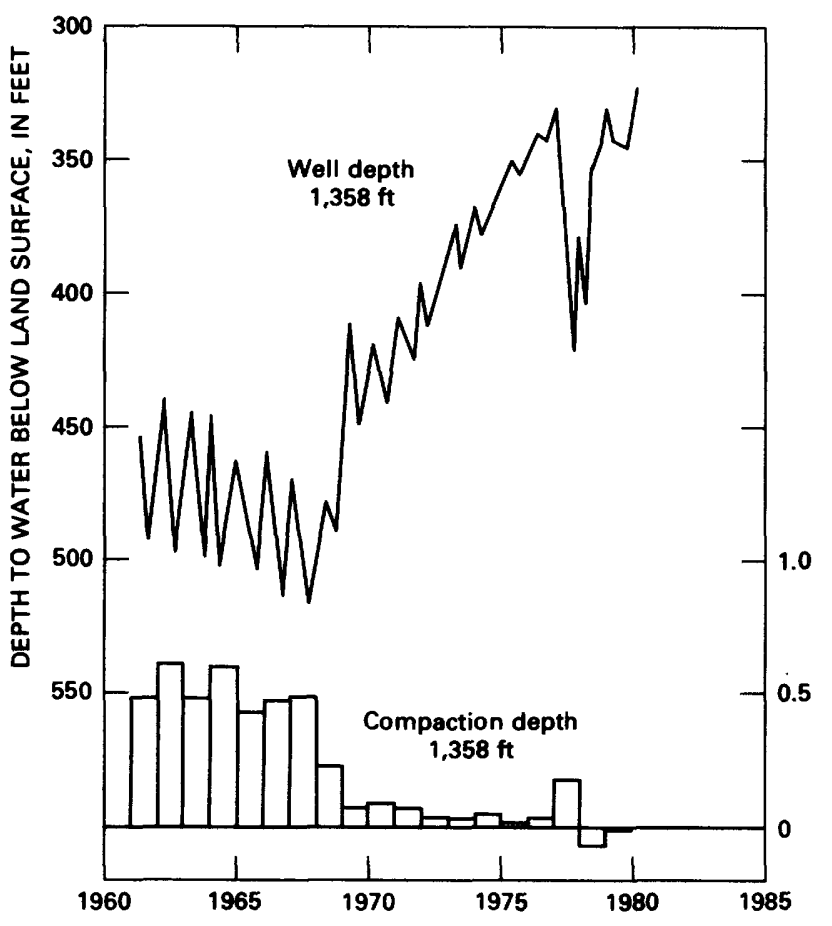

Figure 22.-Seasonal fluctuations of water level and measured compaction in well 14/13-11D6 southwest of Mendota.

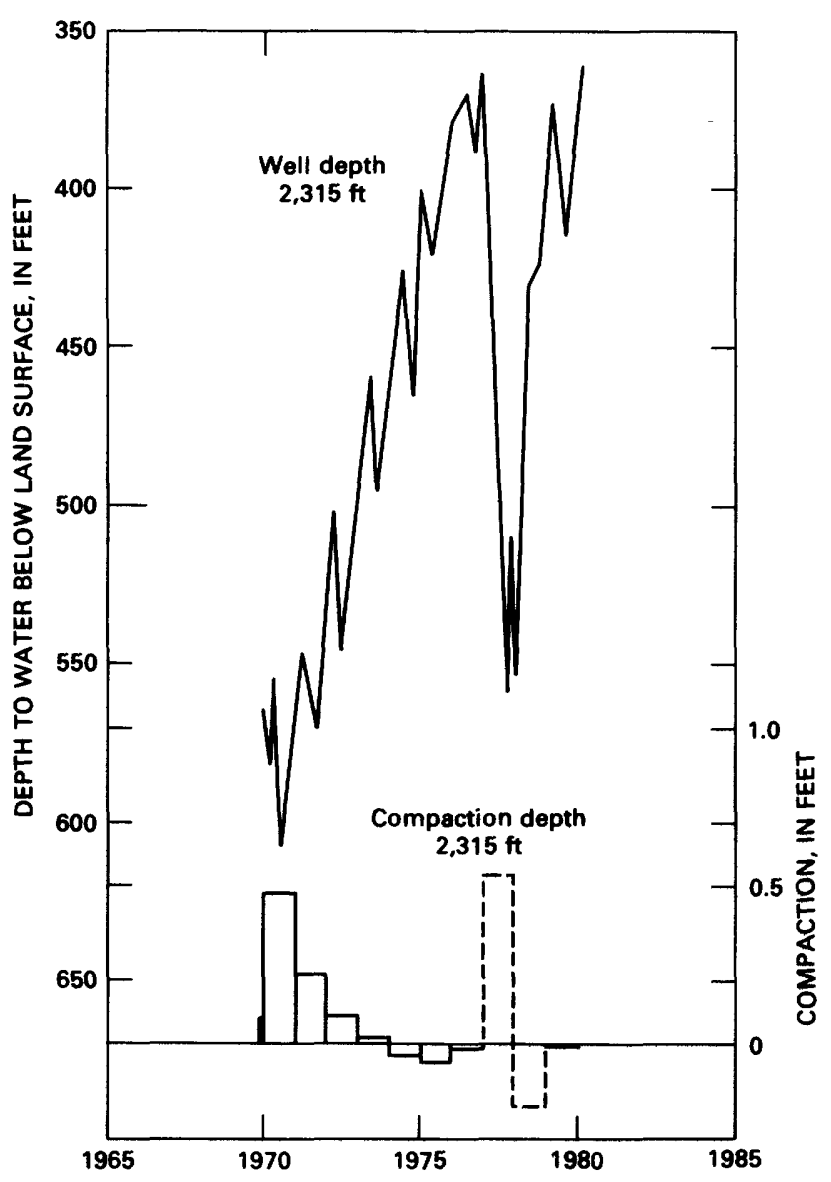

Figure 23.-Seasonal fluctuations of water level and measured compaction in well 17/15-14Q1 south of the town of Cantua Creek.

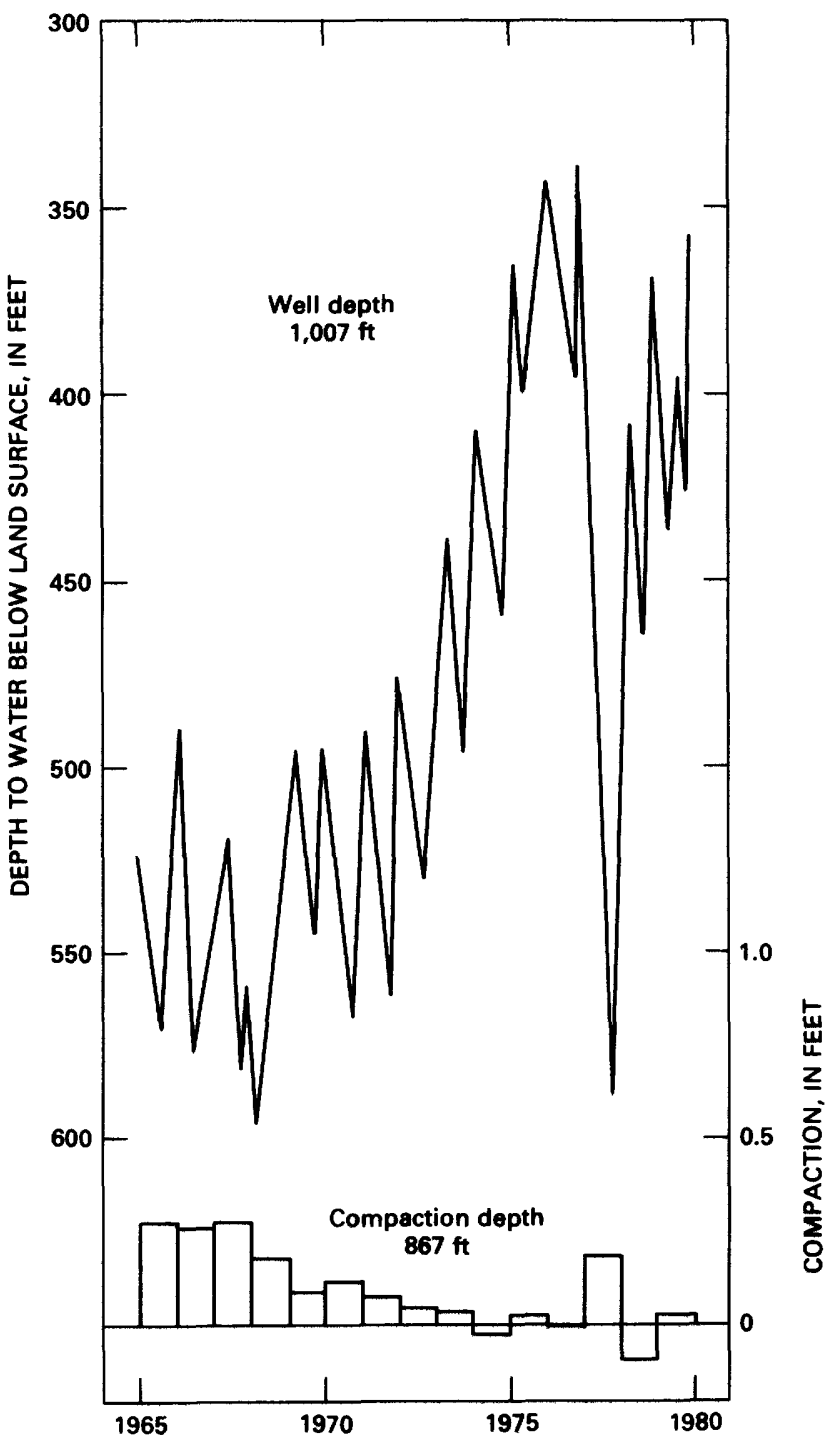

FIGURE 24.-Seasonal fluctuations of water level and measured compaction in well 20/18-6D1 northeast of Huron.

The last areawide leveling in the Tulare-Wasco area was done in 1969-70. Land subsidence from 1926 to 1970 in this area and location of profiles are shown on figure 25.

The only known leveling in this area since 1969-70 was done by the Los Angeles Department of Water and Power in 1974 and 1975. That agency ran a line of levels from bench mark B11 (assumed stable mark in the Sierra Nevada) at Woody (not shown in fig. 25) westward through Delano and Wasco to a proposed nuclear power plant site (which has since been abandoned) west of Wasco.

Profiles of land subsidence from 1957 to 1974 from bench mark 59S, west of Woody, westward through Delano are shown in figure 26. The leveling from 1957 to 1970 is by the National Geodetic Survey. The 1974 leveling is by Los Angeles Department of Water and Power. These profiles show subsidence to be active both east and 
west of Delano through 1974. Maximum subsidence east of Delano near State Highway 65 was $3.5 \mathrm{ft}$ at bench mark E757 from 1957 to 1974. Lofgren and Klausing (1969, fig. 50) showed 1-2 ft of subsidence from 1926 to 1962. Many acres of land were opened up to agriculture in this area in the 1960's and 1970's (Williamson, 1982). Many wells were drilled because surface water was not available; ground-water pumping increased, and ground- water levels declined, causing subsidence rates to increase. Subsidence at bench mark E757 was $1.4 \mathrm{ft}$ from 1964 to 1970 and $1.7 \mathrm{ft}$ from 1970 to 1974 . Maximum subsidence west of Delano at bench mark M541, 1 mi west of State Highway 43, was $4.3 \mathrm{ft}$ from 1957 to 1974.

Profiles of land subsidence along State Highway 46 from Wasco westward to near Lost Hills from 1957 to 1974 (fig. 27) show that subsidence is continuing in this

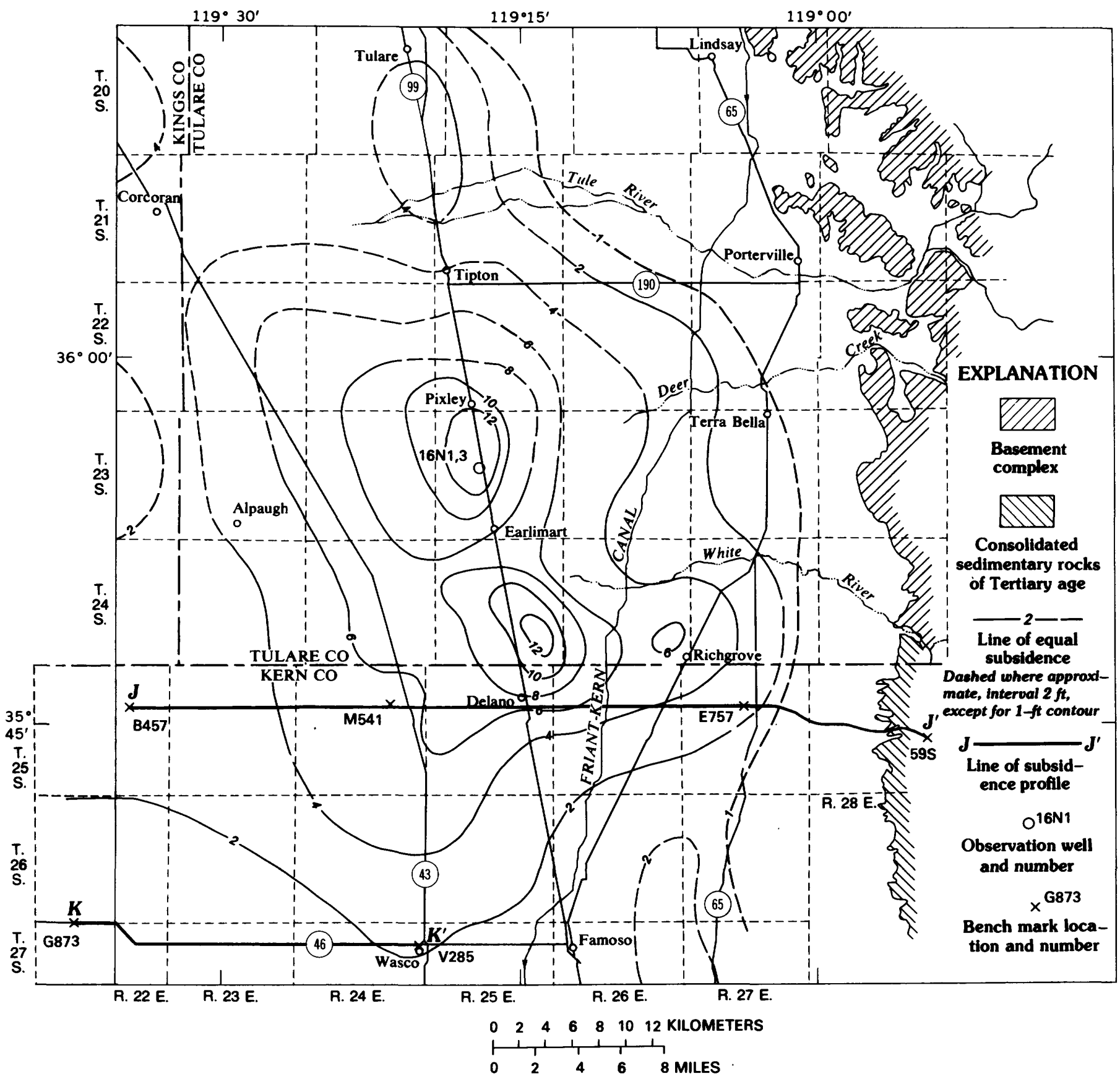

FIGURE 25.-Land subsidence, 1926-70, and location of subsidence profiles, Tulare-Wasco area. Base from U.S. Geological Survey, 1:250,000, Central Valley map, 1958. Compiled from (1) 1948-70 subsidence (Poland and others, 1975, fig. 27), (2) 1926-62 subsidence (Lofgren and Klausing, 1969, fig. 50), and (3) 1962-70 subsidence (Poland and others, 1975, fig. 24). 


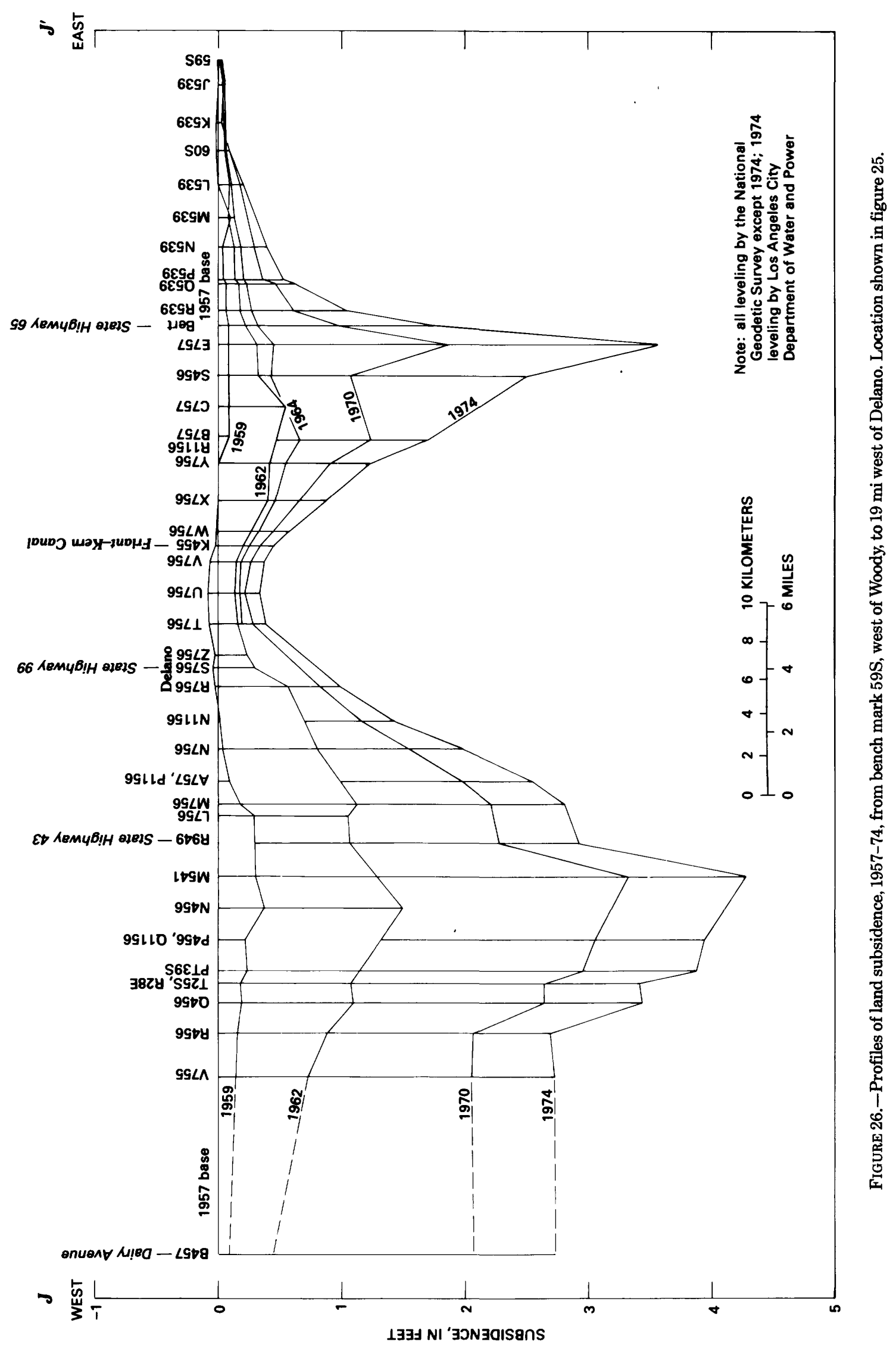


area. West of bench mark T457, subsidence from 1970 to 1974 was more than twice as much as from 1966 to 1970.

The generalized trend of water levels in the confined system near Pixley from 1905 to 1958, and seasonal high and low artesian head fom 1958 to 1980 in observationwell $23 / 25-16 \mathrm{~N} 3$ at the same location are shown in figure 28 . This site is in one of the maximum subsidence centers in the Tulare-Wasco area (fig. 25). The artesian head declined approximately $130 \mathrm{ft}$ from 1905 to 1959 and reached a historic low in the 1977 drought year.

The seasonal fluctuations of water level in observation well 23/25-16N3 and measured compaction in well 23/25-16N1 near Pixley from 1958 to 1980 are shown in figure 29. Water-level data are from the same site as on figure 28. The compaction rates were greatest in the late 1950 's and early 1960 's owing to large withdrawals of ground water. Compaction rates are related inversely to the amount of surface water available and related directly to the amount of ground water pumped. Deeper seasonal lows produced greater amounts of compaction (see fig. 29).

\section{ARVIN-MARICOPA AREA}

Land subsidence in the Arvin-Maricopa area was reported in Lofgren (1975), and Poland and others (1975) updated and summarized the subsidence in this area. Location of the area, $C$, is shown on figure 32 .

The last areawide leveling in the Arvin-Maricopa area was in 1970. The historical land subsidence in the
Arvin-Maricopa area as of 1970 is shown on figure 30. Maximum subsidence exceeded $9 \mathrm{ft}$. Leveling in this area since 1970 was along the California Aqueduct. Bench marks along the California Aqueduct were surveyed by the National Geodetic Survey in 1970 and 1975, and the Elk Hills line was surveyed in 1975 (see figs. 30 and 32 for location). The California Department of Water Resources releveled the California Aqueduct and the Elk Hills line in 1978.

The seasonal water-level fluctuation and measured compaction in well 11N/21W-3B1, 17 mi east of Maricopa is shown on figure 31. (See fig. 30 for location.) Measured compaction was greatest from 1963 through 1970, ranging from 0.30 to $0.45 \mathrm{ft}$ per year as water levels declined at a steady rate. As surface water from the California Aqueduct replaced ground water for irrigation, water levels recovered more than $150 \mathrm{ft}$ from 1970 to 1976 . Compaction rates decreased from 1970 to 1976, averaging about $0.09 \mathrm{ft}$ per year. During the 1976-77 drought, the artesian head declined $90 \mathrm{ft}$ at this site, causing $0.15 \mathrm{ft}$ of compaction in 1976 and $0.23 \mathrm{ft}$ of compaction in 1977. In 1978 water levels recovered and subsidence stopped. In fact, approximately $0.02 \mathrm{ft}$ of expansion was measured in 1978 followed by $0.02 \mathrm{ft}$ of compaction in 1979 .

\section{ESTABLISHMENT AND RELEVELING OF BENCH-MARK NETWORK}

The bench-mark network in the San Joaquin Valley has grown irregularly since the early part of 1900 . The

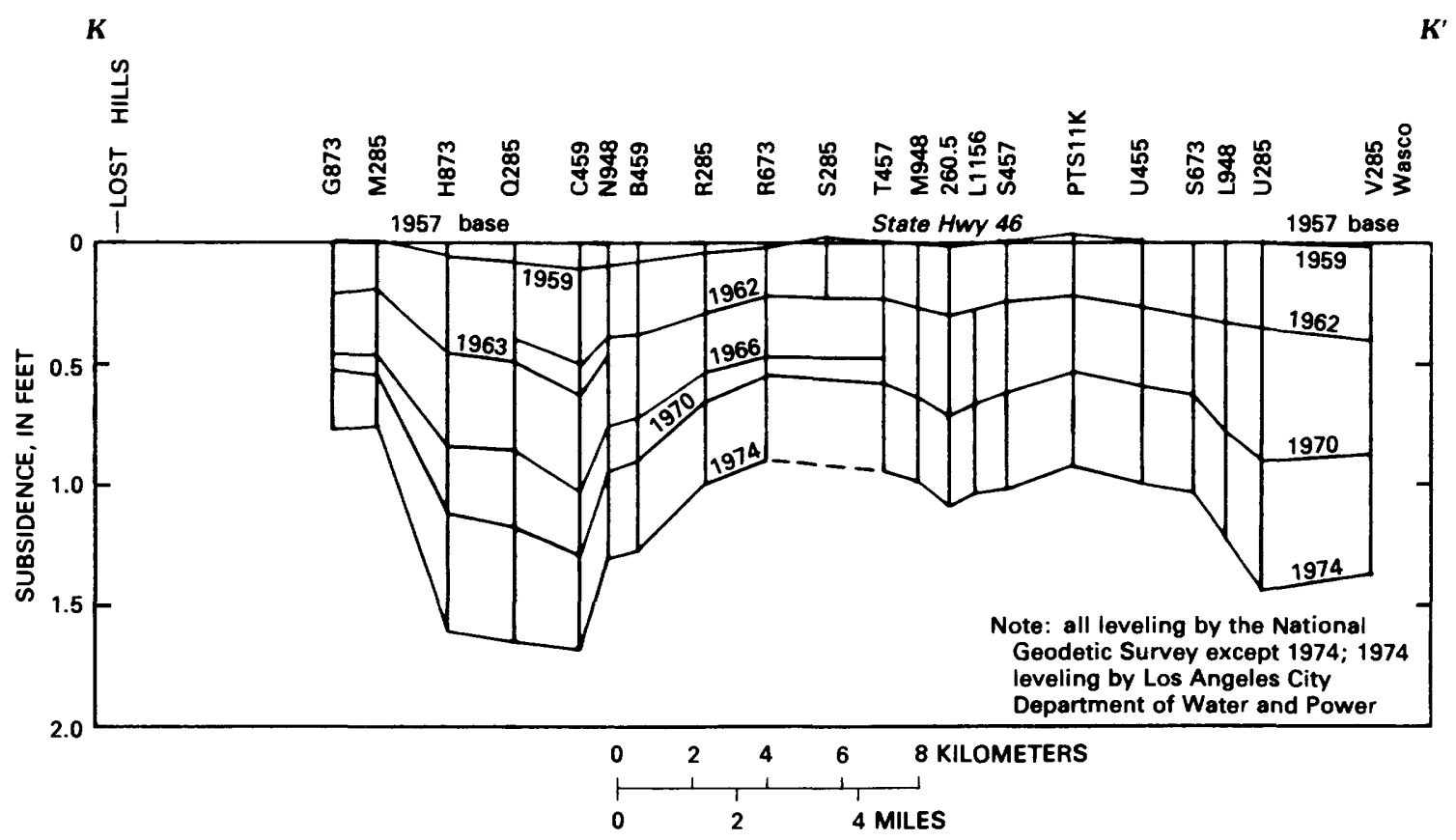

FIGURE 27.-Profiles of land subsidence, 1957-74, from Wasco to near Lost Hills. Location shown on figure 25. 


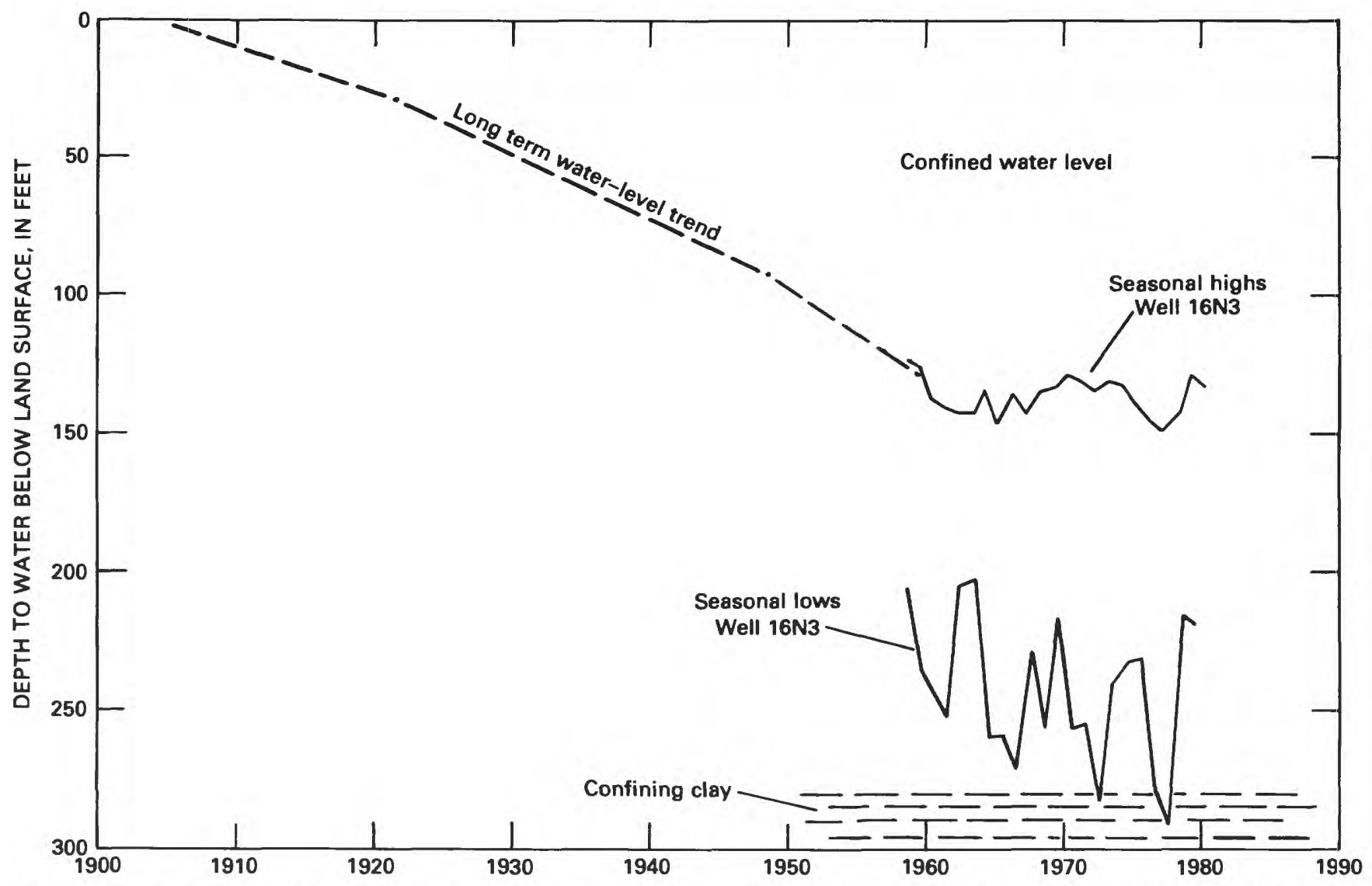

Figure 28.-Long-term trend of water levels near Pixley, and seasonal high and low artesian head in observation well 23/25-16N3. Location shown on figure 25 .

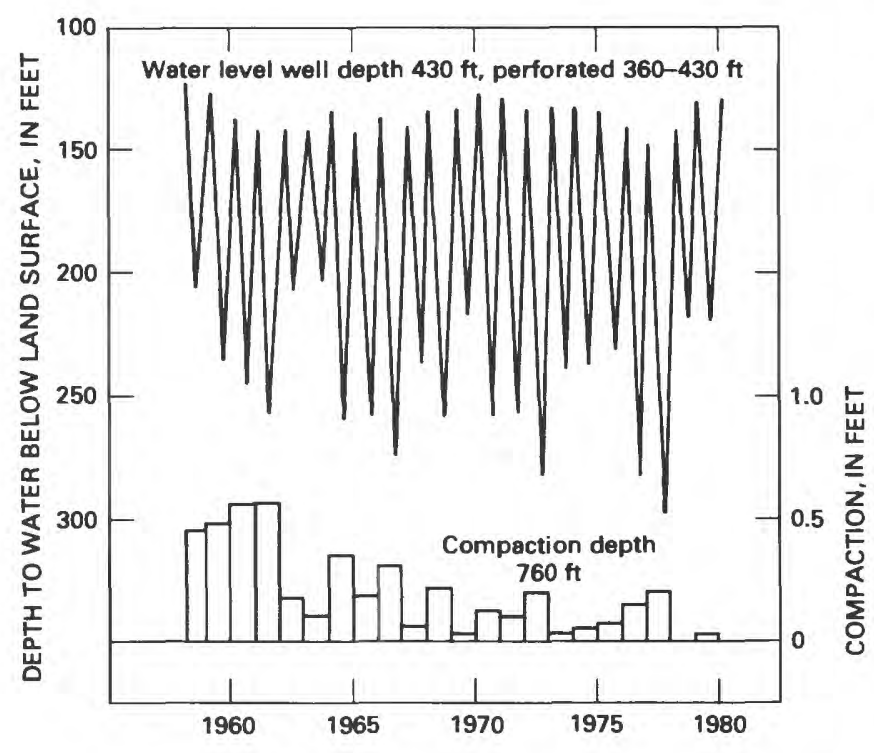

FIGURE 29.-Seasonal fluctuations of water level in observation well $23 /$ 25-16N3 and measured compaction in well 23/25-16N1 near Pixley. Location shown on figure 25 . network of leveling control in the three subsidence areas was periodically resurveyed by the National Geodetic Survey (fig. 32). Control is concentrated in the three subsidence areas and ties are run to about a dozen "stable bedrock" reference bench marks around the perimeter of the valley.

The extent and times of leveling in the Los Banos-Kettleman City, Tulare-Wasco, and Arvin-Maricopa areas are shown in figures 33-35.

In the Los Banos-Kettleman City area, the first leveling was done in 1933 and 1935 by the National Geodetic Survey. The first extensive leveling, done in 1943, was followed by partial levelings in 1947, 1953, and 1954. In 1955 a detailed network of bench marks was laid out and leveled in connection with a topographic map revision program (fig. 33).

In the Tulare-Wasco area, the first precise leveling was done by the Geological Survey along the Southern Pacific railroad in 1901-02. In 1931, a line of first-order levels was run along the Southern Pacific railroad by the National Geodetic Survey. In 1948 a detailed network of lines was laid out and leveled throughout the subsidence area (fig. 34). Beginning in 1957, a tie was made to a stable 


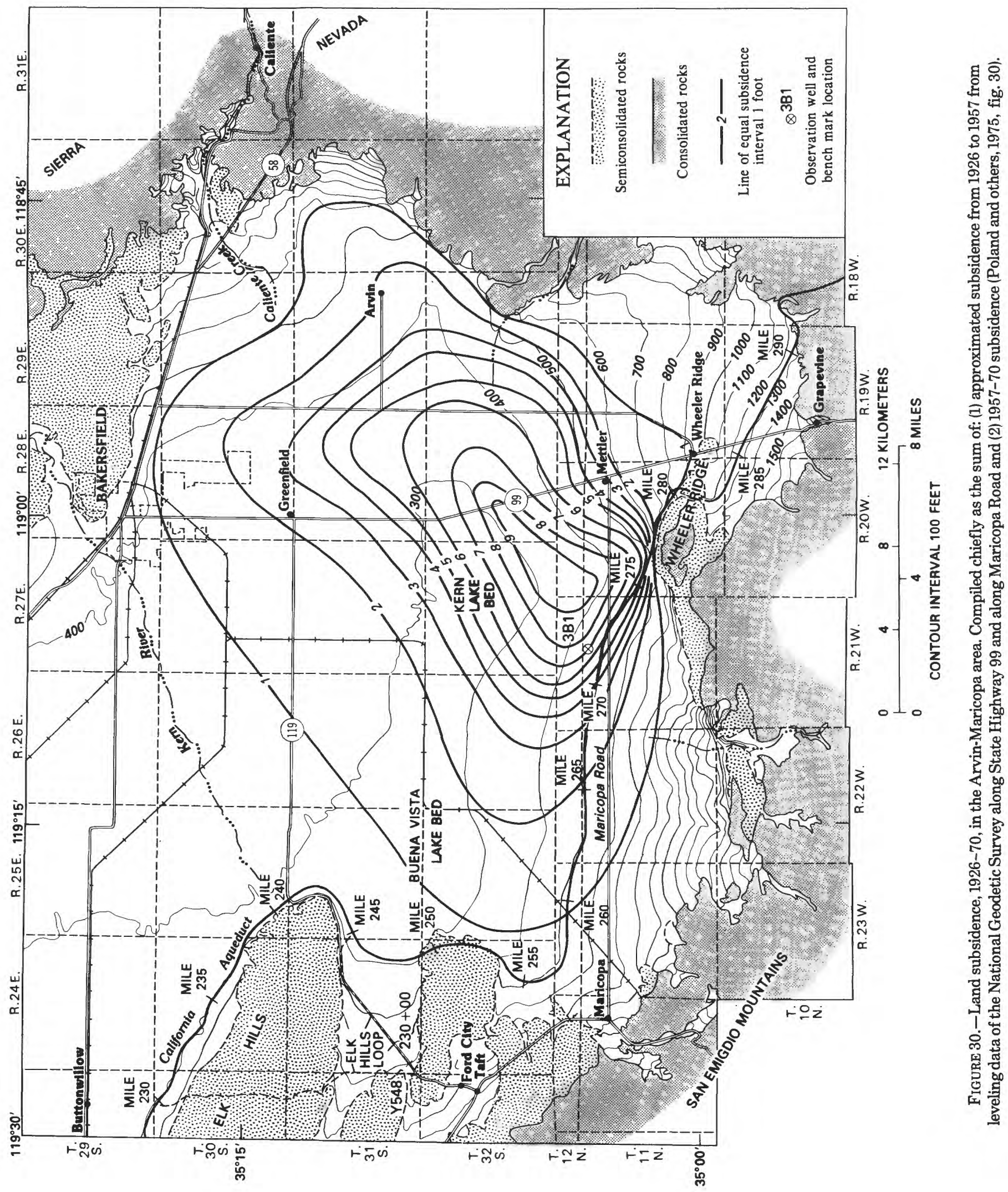




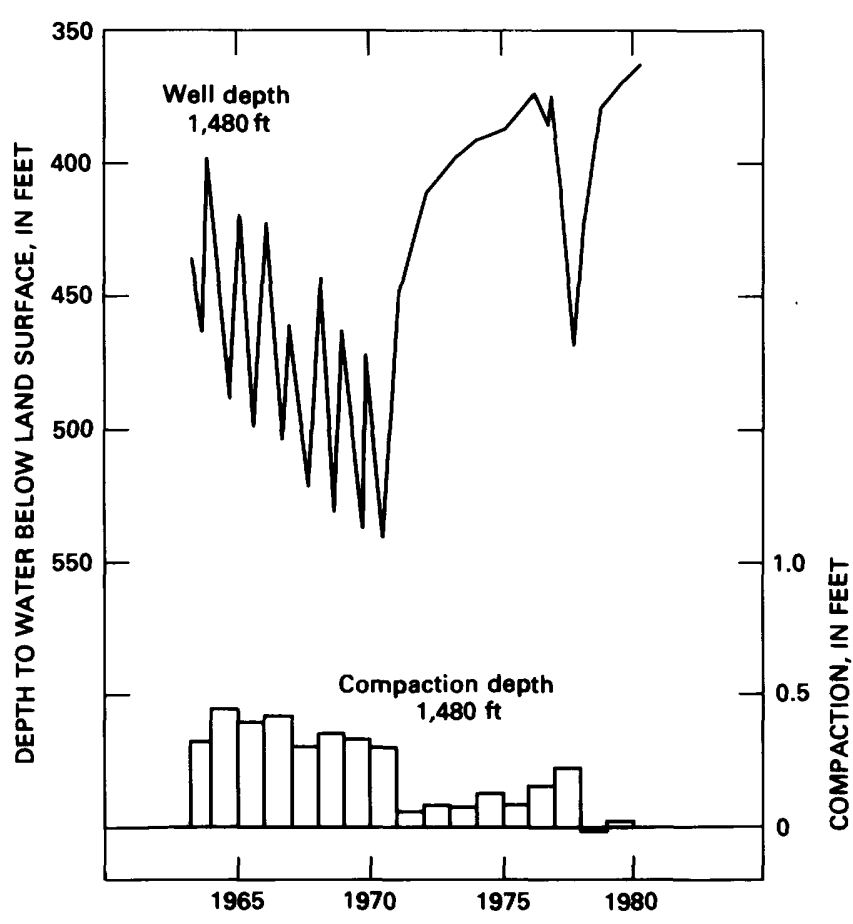

FIGURE 31.-Seasonal fluctuations of water level and measured compaction in well 11N/21W-3B1. Location shown on figure 30 .

bench mark at Woody in the Sierra Nevada. Woody (shown on fig. 32) is about $10 \mathrm{mi}$ due east of State Highway 65 along the easterly projection of the south boundary of T. $25 \mathrm{~S}$. (Lofgren and Klausing, 1969, fig. 37).

The Los Angeles Department of Water and Power ran levels in 1974 and 1975 from Woody westward through Delano and Wasco (fig. 34) to near Lost Hills (shown on fig. 6).

In the Arvin-Maricopa area, the first precise leveling by the National Geodetic Survey was done in 1926-27. Four subsequent partial surveys were run by 1953 . In 1957 , as a result of coordinated efforts of an Inter-Agency Committee, an extensive network of bench marks was established throughout the area of suspected subsidence (fig. 35).

Thus, by 1957, detailed bench-mark networks had been established in all three of the principal subsidence areas.

Level nets in the subsiding areas were surveyed every few years, because of the accelerated subsidence rates during the late 1950's and 1960's. Table 1 shows, for each of the three subsidence areas, the date the network was first established and the years of relevelings of the network.

The National Geodetic Survey leveled the California Aqueduct in February 1967; November-December 1967; December 1968-January 1969; October-November 1969; November 1970-January 1971; November 1971-March
TABLE 1.-Years of leveling control of the network of bench marks in three subsidence areas by the National Geodetic Survey

\begin{tabular}{lcc}
\hline Los Banos-Kettleman City & Tulare-Wasco & Arvin-Maricopa \\
\hline & & \\
\hline 1955 & 1948 & \\
$1957-58$ & 1953 & 1957 \\
$1959-60$ & 1957 & $1958-59$ \\
1963 & $1958-59$ & 1962 \\
1966 & 1962 & 1965 \\
1969 & 21964 & 1970 \\
\hline $1971-72$ & $1969-70$ & - \\
\hline
\end{tabular}

1 Year network established.

Partial releveling of net.

1972; and January-May 1975. These relevelings were sometimes partial lengths of the aqueduct, such as the part in the Los Banos-Kettleman City area.

The California Aqueduct was leveled by the California Department of Water Resources in November 1977-April 1978.

\section{MONITORING ALONG THE GALIFORNIA AQUEDUCT}

Profiles of land-surface change (subsidence) along three segments of the California Aqueduct are included in this report (fig. 6, segments $A-B, B-C$, and $D-E$ ). The northern segment is in the Los Banos-Kettleman City area and extends from aqueduct mile 92 at the FresnoMerced County line to aqueduct mile 174 near Kettleman City (pl. 1; see fig. 36 for location). The middle segment extends from mile 174 near Kettleman City southward past Lost Hills to aqueduct mile 218 (pl. 1; see fig. 6 for location). The southern segment is in the Arvin-Maricopa area and extends from aqueduct mile 238 to aqueduct mile 287 southwest of Wind Gap Pumping Plant (pl. 1; see fig. 6 for location).

Three types of bench marks are used in preparing these aqueduct profiles: bench marks set in the aqueduct lining, bench marks on aqueduct structures, and bench marks adjacent to the aqueduct. Bench marks on aqueduct structures (such as bridges, pumping plants, turnout.structures, and checks) show more settlement, especially differential settlement (structure settlement is greater on one side than the other), than bench marks in the aqueduct lining or bench marks adjacent to the aqueduct. Examples of differential structure settlement are shown on each segment. Bench marks in the aqueduct lining are used on these profiles, where possible, because they are more representative of the aqueduct subsidence.

The aqueduct traverses areas of subsidence due to water-level decline, hydrocompaction, and oilfield subsidence, and these areas may also be affected by tectonic 


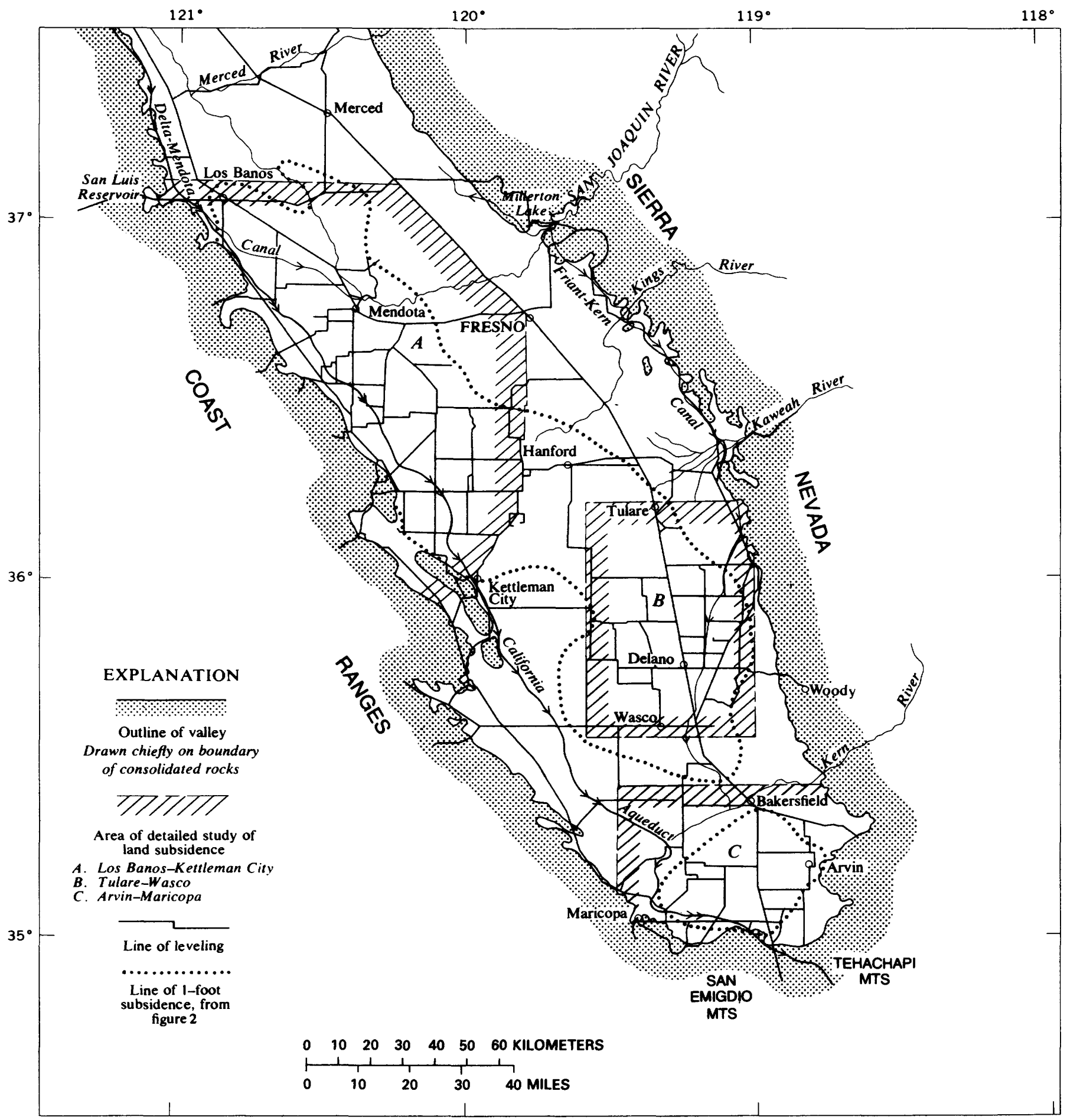

FIGURE 32.-Network of leveling by the National Geodetic Survey and three areas of detailed studies of land subsidence. Base from U.S. Geological Survey, 1:1,000,000, State of California map, 1940. 


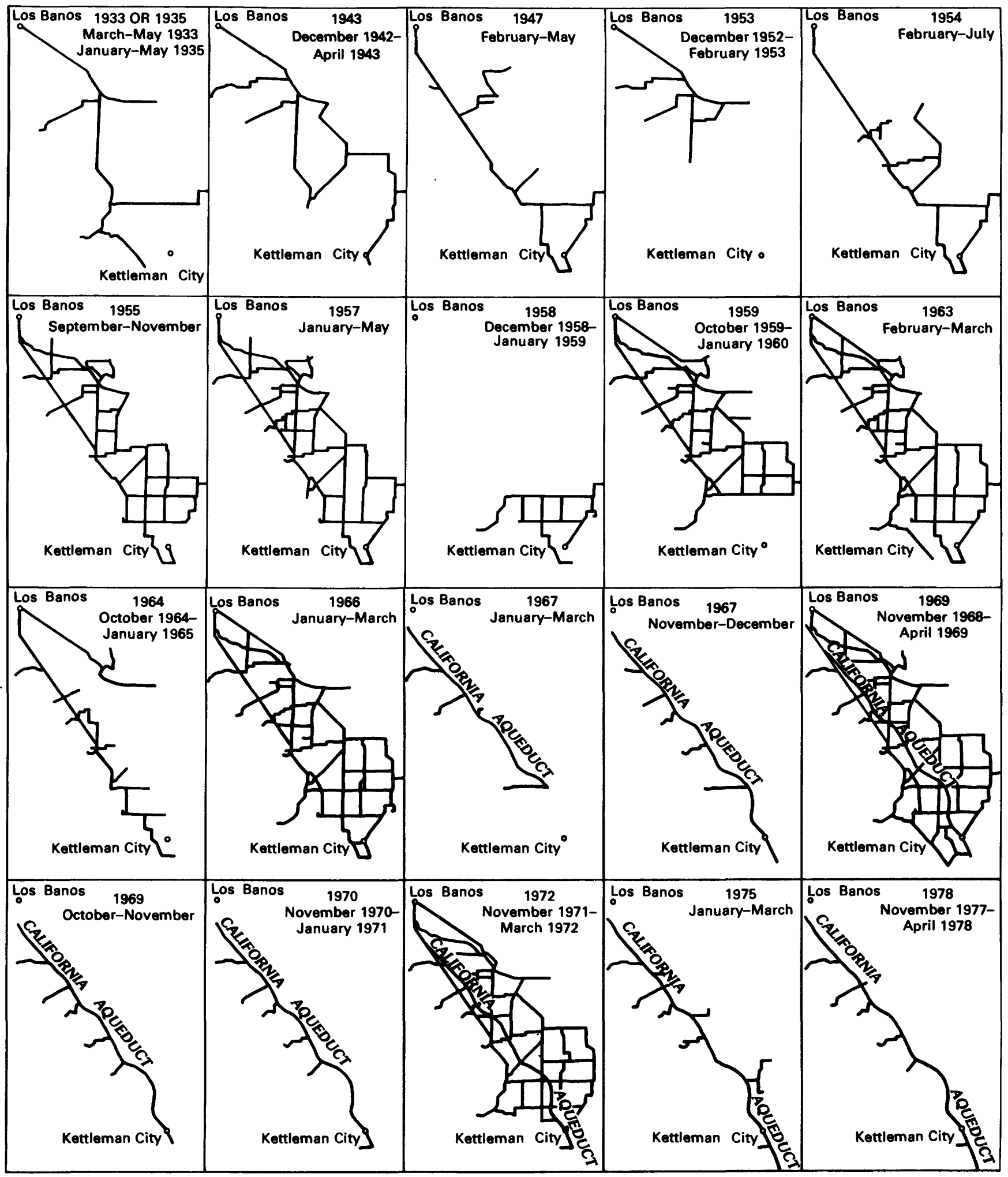

FIGURE 33.-Extent and times of leveling in the Los Banos-Kettleman City area. (All leveling by the National Geodetic Survey except 1977-78 which was by the California Department of Water Resources.) 

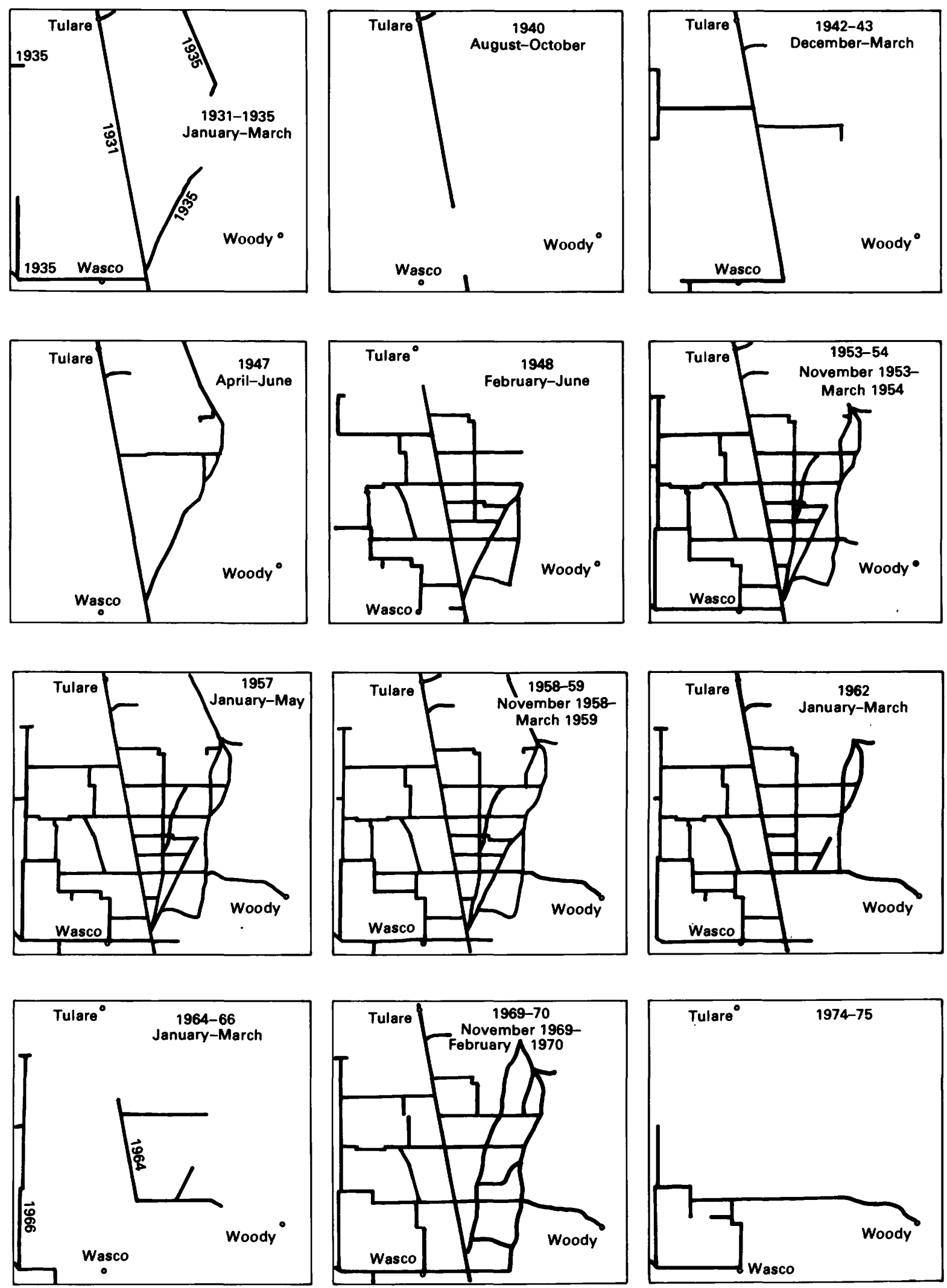

FIGURE 34.-Extent and times of leveling in the Tulare-Wasco area. (All leveling by the National Geodetic Survey except 1974-75 which was by the Los Angeles City Department of Water and Power.) 

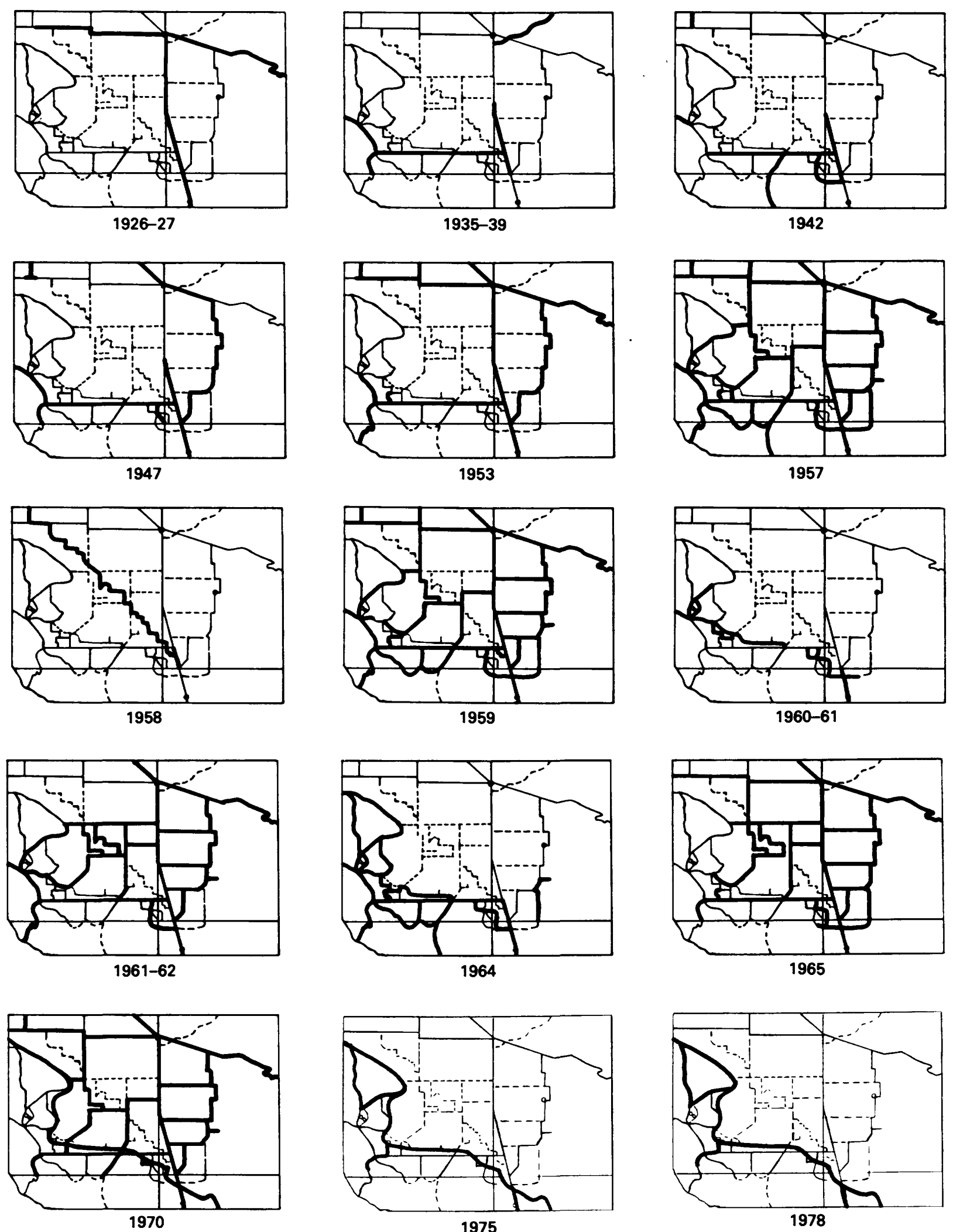

FIGURE 35.-Extent and times of leveling in the Arvin-Maricopa area. (All leveling by the National Geodetic Survey except 1978 which was by the California Department of Water Resources.) 


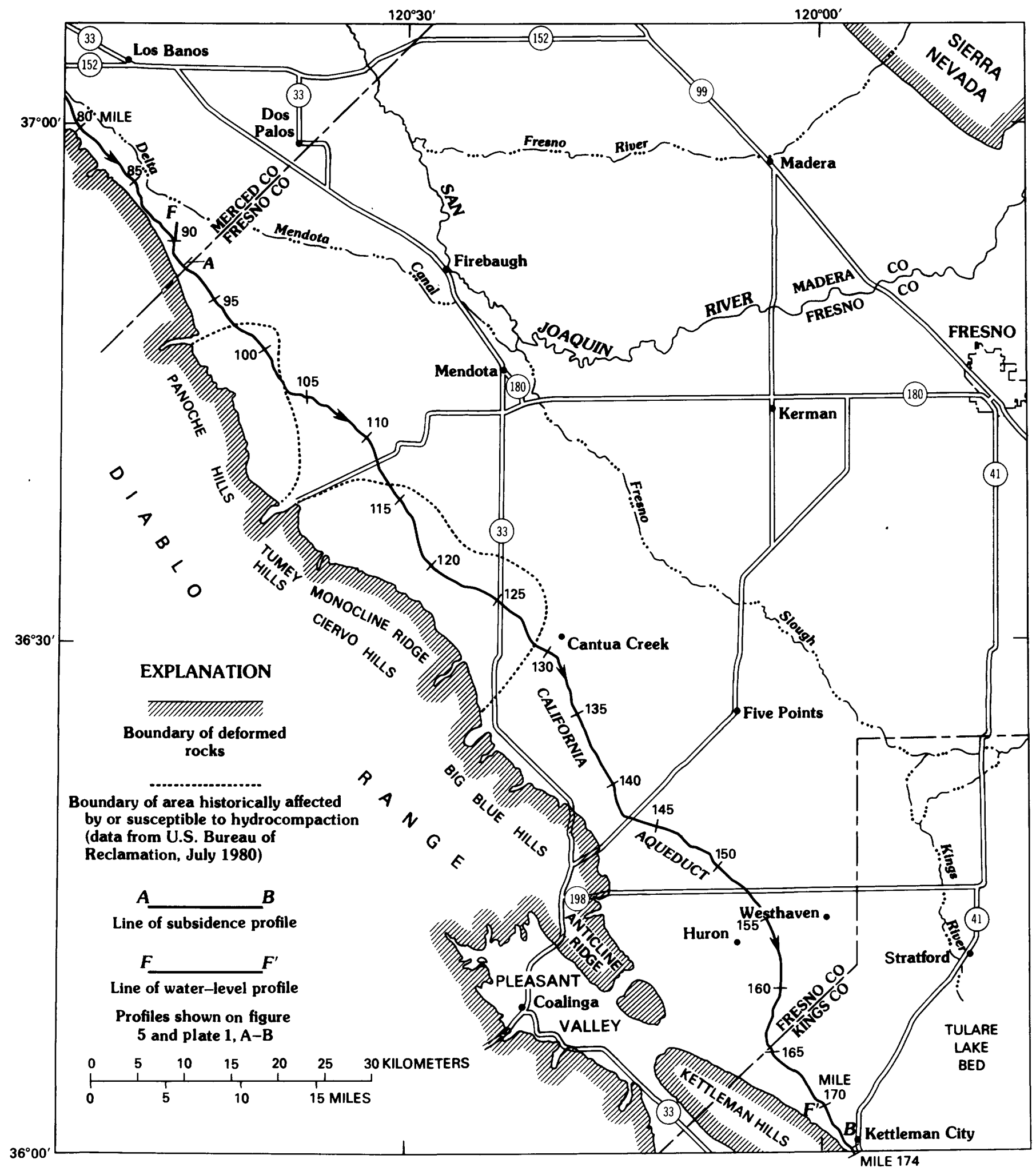

FIGURE 36.-Location of California Aqueduct subsidence and water-level profiles and areas of hydrocompaction in the Los Banos-Kettleman City area. Base from U.S. Geological Survey, 1:250,000, Central Valley map, 1958. 
subsidence. Areas of known hydrocompaction, shown on figure 1, were prewetted along the aqueduct alinement prior to construction.

\section{AQUEDUCT SUBSIDENCE, MILE 92 TO MILE 174}

Profiles of subsidence along the California Aqueduct from mile 92 to mile 174 in the Los Banos-Kettleman City area from 1967 to $1977-78$ are shown on plate 1 . The leveling of November-December 1967 was used as the base instead of the February 1967 leveling because the coverage was more complete in December and also to allow for settlement and stabilization after construction of the aqueduct was completed in 1967-68.

Before examining these profiles, it is helpful to review major changes taking place in this 10 -year periodchanges in importation of surface water and in regional pumping of ground water, and the rapid change in the potentiometric surface (artesian head) of the confined aquifer system (lower water-bearing zone). Total surfacewater deliveries to the San Luis service area (includes about 90 percent of the Los Banos-Kettleman City area) increased from 19,000 acre-ft in 1967 to $1,337,000$ acre-ft in 1976 and then decreased to 308,000 acre-ft in the drought year 1977 (table 2). As a result of the increase in surface water supplied through the aqueduct, pumpage of ground water decreased from 1,040,000 acre-ft in 1967 to about 195,000 acre-ft in 1976, but increased to 542,000 acre-ft in 1977, the second drought year (table 2) ${ }^{2}$. In response to the reduction in ground-water withdrawal after 1967 , the potentiometric surface (artesian head) of the confined system, which had been drawn down steadily for 20-30 years, recovered rapidly from 1967 to 1976 . This recovery is demonstrated by the water-level profiles along the aqueduct (fig. 5), by the regional water-level recovery in the lower zone from 1967 to 1974 (fig. 15), and by the subsidence and extensometer graphs that show the rapid recovery of artesian head and the corresponding reduction in subsidence rates in the 1970's (figs. 16, 17, 21-24).

The leveling of January-March 1975 to the leveling of November 1977-April 1978 show that subsidence rates increased as a result of the 1976-77 drought. Field extensometers and water-level data confirm that most of the subsidence during 1975-77 occurred in 1977, the year of the greatest pumping drawdown (table 3 and figs. 41-56).

The reach of the California Aqueduct from mile 92 to mile 174 has subsided more than any other aqueduct reach. This reach passes through two areas of hydrocompaction (fig. 36) and through the three major subsidence depressions due to water-level decline-(1) southwest of table 3).
TABLE 2.-Surface-water deliveries through the joint-use reach of the California Aqueduct and estimated ground-water pumpage in the Los Banos-Kettleman City area, 1967-77

[Surface-water deliveries for calendar year; data from U.S. Bureau of Reclamation. Deliveries are to San Luis service area and include water pumped from Mendota Pool by Westlands Water District. Ground-water pumpage for agricultural year beginning April 1 and ending March 31 for years 1967 through 1971 and for calendar years 1974 through 1977]

\begin{tabular}{lcc}
\hline & $\begin{array}{c}\text { Surface-water } \\
\text { deliveries }\end{array}$ & $\begin{array}{c}\text { Ground-water } \\
\text { pumpage }\end{array}$ \\
\cline { 2 - 4 } 1967 & \multicolumn{2}{c}{ (Thousands of acre-fest) } \\
\hline 1968 & 19 & 1,040 \\
1969 & 209 & 750 \\
1970 & 306 & 685 \\
1971 & 478 & 605 \\
1972 & 650 & 515 \\
1973 & 865 & No data \\
1974 & 856 & No data \\
1975 & 1,129 & 1194 \\
1976 & 1,368 & 1188 \\
1977 & 1,337 & ${ }^{1} 195$ \\
\hline 1For years 1974-77, estimates of pumpage in Westlands Water District (Mitten, 1980) \\
were increased by 100,000 acre-ft per year to obtain estimated pumpage in the Los \\
Banos-Kettleman City area
\end{tabular}
Banos-Kettleman City area.

Mendota, (2) near the town of Cantua Creek, and (3) near the town of Huron (fig. 4). Because of the rapid rates of subsidence in the late 1960's, more freeboard was added to the aqueduct in 1971 from mile 129 to mile 137, south and east of the town of Cantua Creek. More freeboard will be added to other subsiding areas along this reach in the near future.

Subsidence rates were greatest from the leveling of November-December 1967 to that of December 1968-January 1969. During this 13-month period, subsidence ranged from less than a hundredth of a foot at bench mark J1072 at aqueduct mile 92 near the Fresno-Merced County line to a maximum of $1.4 \mathrm{ft}$ at bench mark R1093 at aqueduct mile 128 west of the town of Cantua Creek (pl. 1).

Note that the subsidence profiles along the aqueduct are drawn with a vertical scale of $1 \mathrm{in} .=1 \mathrm{ft}$, whereas the horizontal scale is $1 \mathrm{in} .=2 \mathrm{mi}(10,560 \mathrm{ft})$. Thus, the vertical scale is 10,560 times as great as the horizontal scale. This scale difference serves to magnify greatly even very small lateral differentials in the magnitude of subsidence.

In 1967 the artesian head in the permeable coarsegrained aquifers was at its historical low. The recovery of head began in 1968, and during the 1970's pore pressures in the aquifers gradually increased toward equilibrium with residual excess pore pressures in the fine-grained compressible aquitards. The average effective stress and the rate of subsidence decreased at a fairly uniform rate from 1968 to 1976.

Compared with the November-December 1967 base, all the successive profiles show continuing subsidence with the exception of the January-March 1975 profile. 
Between aqueduct miles 142 and 155, the 1975 profile shows as much as $0.2 \mathrm{ft}$ of apparent rebound from the November 1971-February 1972 profile (pl. 1). The word "apparent" is used advisedly because there was some problem in the adjustment of bench-mark elevations for the 1975 releveling, although the same procedure was followed as during the earlier surveys by the National Geodetic Survey. Extensometers in the Los BanosKettleman City area indicate a net compaction in the 3 years 1972 to 1975 . Although the artesian head of the lower zone was recovering rapidly in that period and minor rebound may well have occurred locally, the 1975 profile should be viewed with caution. The 1972 and 1978 profiles would not be affected because the values were derived from independent adjustments.

With the exception of the two areas susceptible to hydrocompaction and apparent minor subsidence of the Coalinga oilfield in the foothills (Bull, 1975, p. F8), all the subsidence that has been mapped in the Los Banos-Kettleman City area since the 1920's is attributed to the great decline in artesian head, the consequent increase in effective stress, the compaction of the confined aquifer systems, and the resulting subsidence of the land surface. Within the two areas susceptible to hydrocompaction, two types of subsidence have occurred, namely: (1) regional subsidence due to aquifer-system compaction, and (2) hydrocompaction of moisture-deficient deposits between land surface and the water table when first wetted by downward percolating irrigation water.

Because of the severe differential subsidence produced by the hydrocompaction during many years of irrigation, and as a result of field tests producing more than $10 \mathrm{ft}$ of hydrocompaction (Bull, 1964a), the aqueduct builders, both Federal and State, concluded that the aqueduct alinement within the areas subject to hydrocompaction should be prewetted from land surface to the water table to preconsolidate the deposits prior to construction of the aqueduct. This prewetting between aqueduct miles 98-103 and aqueduct miles 114-129 (fig. 36 and pl. 1) was done in 1964 and 1965 . If the prewetting had achieved complete success, all deposits underlying the aqueduct alinement in these two reaches would be preconsolidated from the land surface to the water table, no additional hydrocompaction would occur, and none of the subsidence shown on plate 1 would be caused by hydrocompaction.

The two hydrocompaction areas, aqueduct miles 98-103 and 114-129, were preconsolidated in the following ways (Hall and Carlson 1965; U.S. Bureau of Reclamation 1974). Preconsolidation ponds, $400-425 \mathrm{ft}$ wide and of various lengths, were constructed to saturate both the aqueduct prism and the soil upon which the aqueduct embankments would be placed. Ponds were flooded $1 \frac{1}{2}-2$ $\mathrm{ft}$ deep for 12-18 months. Gravel-packed infiltration wells
75,100 , and $125 \mathrm{ft}$ deep on a 100 -ft grid were installed in the central two-thirds of the ponds to speed water delivery to dry deposits. In the preliminary investigation, test holes, $200 \mathrm{ft}$ deep, were drilled on 1-mi centers to the approximate water table to obtain moisture and density determinations and again, after preconsolidation of the aqueduct alinement, to determine whether moisture from preconsolidation ponding had reached the moisture-deficient deposits.

Maximum subsidence in the northern hydrocompaction area was $2 \frac{1}{2} \mathrm{ft}$ and in the southern hydrocompaction area was more than $5 \mathrm{ft}$ in $1 \frac{1}{2}$ years.

Hall and Carlson (1965) predicted a certain amount of residual hydrocompaction would occur even after $1 \frac{1}{2}$ years of saturation.

The subsidence profiles define two features within the extent of the larger hydrocompaction area that display recurring "sags" in the profiles, repeated in each releveling. These sags, centered at aqueduct miles 120 and 128 , look like major features at the greatly distorting scale ratio. Actually, the overall sag at mile 120 is about 1 mi wide and has undergone $2.7 \mathrm{ft}$ of subsidence at bench mark A1093 since November-December 1967, about 0.9 $\mathrm{ft}$ more than the regional subsidence at nearby bench marks Z1092 and B1093. The sag at mile 128 is about $3 \mathrm{mi}$ wide and has undergone $3.9 \mathrm{ft}$ of subsidence at bench mark R1093 since November-December 1967, whereas the regional subsidence at nearby bench marks N1093 and T1093 was 2.4 and $3.0 \mathrm{ft}$, respectively.

In 1972 the California Department of Water Resources requested that the Geological Survey examine differential changes in elevation of the aqueduct, particularly near these two prominent sag areas, to see if any geologic anomalies of possible tectonic origin appeared to be developing. The physical dimensions of the two sags and their systematic growth does not suggest that these are geologic anomalies of tectonic origin. It is more likely that these two recurrent sags are caused by continuing hydrocompaction (consolidation) of two "islands" of deposits (of low vertical permeability) that have not yet been completely wetted. Test holes drilled to the water table and carefully sampled for moisture content could determine if these are "islands" of continuing hydrocompaction.

Measured compaction to a depth of $2,000 \mathrm{ft}$ at extensometer site 16/15-34N1 (fig. 49) (see fig. 40 for location) was 90 percent of the subsidence measured at bench mark G1046 between November-December 1967 and November 1971-February 1972. The data from the multiple extensometers at this site show that $0.46 \mathrm{ft}$ of compaction (table 6) occurred above $503 \mathrm{ft}$ and $1.57 \mathrm{ft}$ occurred from 503 to $2,000 \mathrm{ft}$, that is, within the confined aquifer system. The 10 percent of total subsidence not accounted for by measured compaction presumably represents 
compaction below the bottom of the 2,000-ft extensometer, inasmuch as nearby wells extend to $2,750 \mathrm{ft}$. The data show that most of the subsidence at this site is caused by compaction of the aquifer system due to the pumping of ground water. This extensometer site and bench mark are $1 / 4$ mile south of the aqueduct at mile 130 , southeast of the hydrocompaction area shown on figure 36 .

Bench mark $100.55 \mathrm{~L}$, an example of differential bench-mark settlement (pl. 1) is located on the left side of Shields Avenue Bridge. This bench mark subsided $1.50 \mathrm{ft}$ from 1967 to 1978 , whereas bench mark 100.55R (not shown), located on the right side of the same bridge, subsided only $0.88 \mathrm{ft}$ for the same period. Bench mark S1072, a mark in the aqueduct lining one-half mile north of Shields Avenue Bridge, and bench mark Z1072, a bench mark adjacent to the aqueduct $0.6 \mathrm{mi}$ south of Shields Avenue Bridge, show $0.99 \mathrm{ft}$ and $1.05 \mathrm{ft}$ for the same period. This is a hydrocompaction area and was prewetted before construction.

\section{AQUEDUCT SUBSIDENCE, MILE 174 TO MILE 218}

Profiles of land subsidence along the California Aqueduct south of Kettleman City from mile 174 to mile 218 are shown on plate 1 (see fig. 6 for location). The base for these profiles is October 1967-January 1968. In the 10year period 1967-77, these profiles show little or no change from mile 174 to mile 192 . From aqueduct mile 192 , the subsidence gradually increases to $1.2 \mathrm{ft}$ between mile 197 and mile 198. Subsidence then decreases to less than $0.5 \mathrm{ft}$ at mile 204, increases to a maximum of $1.45 \mathrm{ft}$ at mile 208, and then gradually decreases to $0.45 \mathrm{ft}$ at mile 218.

The bench-mark numbers (aqueduct miles) originally assigned by the California Department of Water Resources and used by the National Geodetic Survey through 1975 for bench marks from aqueduct mile 172 near Kettleman City to aqueduct mile 220 were about 2.3 $\mathrm{mi}$ in error. Corrected mileage and bench-mark numbers of the Department of Water Resources are used in this report.

Bench mark X1097, at aqueduct mile 196.75 on a turnout structure shown on this profile, is an example of structure settlement that is probably not related to the areal subsidence. The data show that this structure has subsided a maximum of $1.6 \mathrm{ft}$ since construction, whereas bench mark 196.57B, 0.2 mi north, and located in the aqueduct lining, has subsided $0.9 \mathrm{ft}$ and bench mark $197.05 \mathrm{~B}, 0.3 \mathrm{mi}$ south and located in the aqueduct lining, has subsided $1.1 \mathrm{ft}$.

The axis of the Lost Hills oilfield is approximately parallel to the aqueduct, and is 1-1.5 mi southwest. The productive limit of the field extends from aqueduct mile
198 to mile 207 (pl. 1). The discovery well, drilled in 1910 , was completed at a depth of $530 \mathrm{ft}$. The shallower oilproducing horizons are $200-1,300 \mathrm{ft}$ in depth; the deeper horizons are below a depth of $4,900 \mathrm{ft}$.

Leveling surveys of bench marks along State Highway 46 at and near Lost Hills indicate that substantial subsidence has occurred both before and since the aqueduct was completed in 1967. Profiles of land subsidence along State Highway 46, from 3 mi west of Lost Hills (town) to $3 \frac{1}{2} 2$ mi east are shown on figure 37 (see fig. 6 for location). Subsidence values for surveys prior to 1966 (pre-aqueduct) are plotted above the base, and values for subsequent surveys are plotted below the base. The most remarkable feature of this figure is the uniform subsidence of $0.4-0.5 \mathrm{ft}$ that occurred from 1953 to 1966 by all the bench marks in the $4 \frac{1}{2}$-mi reach from bench mark C873 to G873 at the east end of the section. The reason for this uniform subsidence is not known. Lofgren (1975, p. D13-D15) stated that all bench marks in this area have a component of apparent subsidence which is not real. All or part of this apparent change (subsidence) from 1953 to 1966 may be related to tectonic uplift at supposedly stable bench marks in the Tehachapi Mountains to the south, the Sierra Nevada to the east, and the Coast Ranges to the west. Note that bench mark G873, at the west end of the subsidence profile from Wasco to near Lost Hills (fig. 27), is common to both sets of profiles. The subsidence of the area 2 mi east of bench mark G873 (fig. 27) from 1957 to 1974 is double that of G873 and was caused by increased ground-water development in the 1960's.

Bench mark Y544 (fig. 37) at Lost Hills and east of the aqueduct subsided $0.41 \mathrm{ft}$ from 1957 to 1966 and 0.59 $\mathrm{ft}$ from 1967 to 1978. Also bench marks E873 and 153A, about 0.5 mi west from Y544 and west of the aqueduct, subsided $0.41 \mathrm{ft}$ from 1953 to 1967 and $0.73 \mathrm{ft}$ from 1967 to 1978. Two miles west of Lost Hills at the axis of the oilfield, bench mark 383.7 subsided $1.22 \mathrm{ft}$ from 1935 to 1953 and $1.02 \mathrm{ft}$ from 1953 to 1966 . These figures indicate that the crest of the oilfield due west of the town subsided 2.24 $\mathrm{ft}$ from 1935 to 1966 and probably has subsided considerably more since oil production began in 1910 . No surveys were made between 1910 and 1935, and this bench mark has not been resurveyed since 1966.

From 1967 to 1978, subsidence of the aqueduct parallel with the axis of the Lost Hills oilfield (aqueduct mile 198-207, pl. 1) ranged from 0.4 to $1.3 \mathrm{ft}$. At Lost Hills (town), the aqueduct has subsided 0.6-0.7 ft since 1967 . This subsidence probably is due in part to continued removal of oilfield fluids and compaction of the shallow oil zones of the Lost Hills field. From aqueduct mile 198 to Lost Hills (mile 205), the oilfield subsidence is not known and, hence, no comparison can be made with the aqueduct subsidence. 
The reason for the subsidence in aqueduct miles 195-198 and 207-215 is not known. According to Wood and Davis (1959), the quality of the ground water beneath the Antelope Plain is generally poor, and for this reason, water wells are scarce.

Ground-water pumpage data from some westside townships were published for years 1962-66 (Ogilbee and Rose, 1969a), 1967-68 (Mitten, 1972), 1969-71 (Mitten, 1976), and 1975-77 (Mitten, 1980). The Geological Survey, as part of the Central Valley Aquifer Project, has prepared estimates of ground-water pumpage for additional townships in this area. A review of these data for townships crossed by the aqueduct from $15 \mathrm{mi}$ north of Lost Hills (from aqueduct mile 190) to $10 \mathrm{mi}$ south of Lost Hills (to aqueduct mile 215) shows that the only township in which ground-water pumping is appreciable is T. $27 \mathrm{~S}$., $R$. $21 \mathrm{E}$. The north boundary of this township extends from 2 mi east of Lost Hills (town) to 4 mi west. The estimated annual average ground-water pumpage from this township was 23,400 acre-ft per year for 1961-66 and 18,600 acre-ft per year for 1967-77. These quantities are equivalent to $1 \mathrm{ft}$ and $0.8 \mathrm{ft}$ of water, respectively, if applied to the full township acreage (23,040 acres). This amount of water is only one-half to one-quarter of the crop irrigation requirements in the San Joaquin Valley. Water-level measurements made in the 1970's are available for three wells in the township. In the three wells, water levels are less than $80 \mathrm{ft}$ below land surface and have been rising. The evidence just summarized, although fragnentary, suggests that ground-water withdrawal and decline of water levels has not contributed appreciably to subsidence of the aqueduct in the reach from aqueduct mile 190 to aqueduct mile 215 .

Limited or local deposits susceptible to hydrocompaction may be present and may have been wetted and compacted by water leaking from the aqueduct or used for irrigation.

The State made contracts for preconsolidation of hydrocompactible deposits at aqueduct mile 177.4 to 177.7 (Arroyo Pino Creek), and also from aqueduct mile 215.6 to aqueduct mile 239 (pl. 1). Profiles of aqueduct subsidence were not drawn for the $20-\mathrm{mi}$ reach from aqueduct mile 218 to 238 because maximum subsidence in the reach did not exceed $0.5 \mathrm{ft}$. Subsidence from 1969-70 to 1978 was 0.25 to $0.50 \mathrm{ft}$ from aqueduct mile 218 to mile 230 near Elk Hills and 0.20 to $0.30 \mathrm{ft}$ from aqueduct mile 230 to mile 239. Bench marks along this 9-mi length, mile 230 to mile 239, show an apparent minor recovery of $0.01-0.03 \mathrm{ft}$

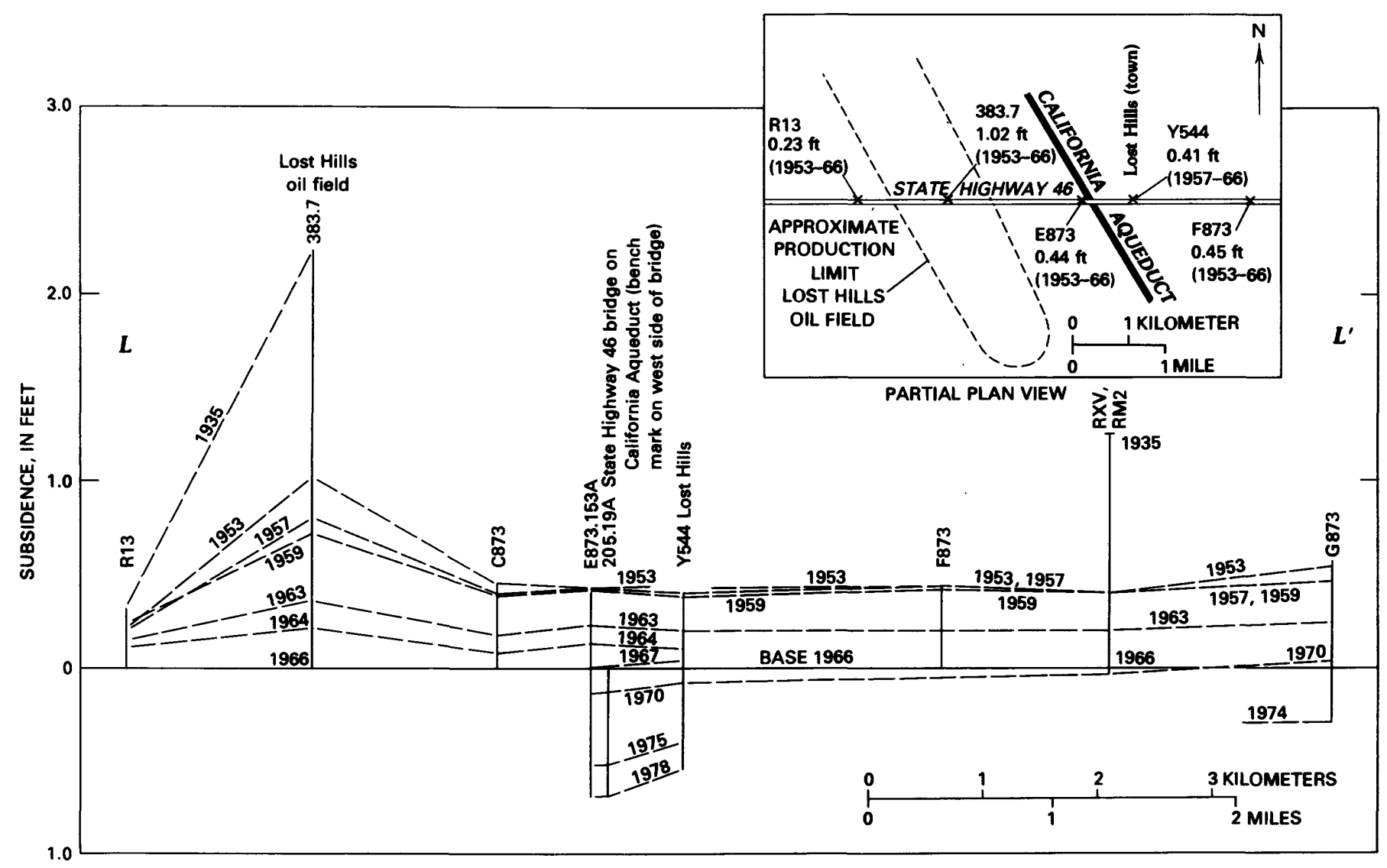

FIGURE 37.-Profiles of land subsidence along State Highway 46 near Lost Hills. Location shown on figure 6. 
from 1975 to 1978 suggesting that the subsidence occurred from 1970 to 1975.

\section{AQUEDUCT SUBSIDENCE, MILE 238 TO MILE 287}

Profiles of land subsidence from 1970 to 1978 along the California Aqueduct from mile 238 to mile 287, southwest of Wind Gap Pumping Plant are shown on plate 1 (see fig. 6 for location). The subsidence illustrated by these profiles represents change related to fluid withdrawal, hydrocompaction, and probably construction settlement.

Areas of known hydrocompaction and the area of subsidence greater than $1 \mathrm{ft}$ due to water-level decline in the Arvin-Maricopa area are shown on figure 38. Areas of known hydrocompaction along the aqueduct alinement were from mile 254 to mile 261 , mile 274 to mile 280.5 , and mile 282.5 to mile 286 (pl. 1 and fig. 38). As shown on plate 1, the State contracted for preconsolidation of hydrocompactible deposits from aqueduct mile 255.7 to mile 288.7. The regional subsidence greater than $1 \mathrm{ft}$ due to fluid withdrawal from 1926 to 1970 extends from aqueduct mile 259 to mile 280 (pl. 1).

From aqueduct mile 238 to mile 254, the subsidence was generally less than $0.25 \mathrm{ft}$ from 1970 to 1978 . The profiles along this 17-mi reach show a maximum subsidence of $0.5-0.6 \mathrm{ft}$ near mile 241 . This sag, which is $1-2 \mathrm{mi}$ long, is probably due to construction settlement and (or) hydrocompaction (prewetting for the hydrocompaction area to the northwest stopped at mile 238). The 1978 elevations show an apparent small land-surface recovery from aqueduct mile 238 to near mile 243 .

Subsidence again reached one-half foot at mile 254, in the next known hydrocompaction area. From aqueduct mile 254-261 (known hydrocompaction area), subsidence ranges from near $0.25 \mathrm{ft}$ to near $1 \mathrm{ft}$ except at bench marks 255.77B and K1210. Bench mark 255.77B in the aqueduct lining subsided $1.31 \mathrm{ft}$ from 1970 to 1975 and $0.91 \mathrm{ft}$ from 1975 to 1978 . Bench mark K1210, set in an aqueduct structure (concrete overchute), shown at aqueduct mile 255.75, subsided $1.12 \mathrm{ft}$ from 1970 to 1975 and $0.98 \mathrm{ft}$ from 1975 to 1978 . Bench marks 255.00B and $255.36 \mathrm{~B}$, in the aqueduct lining to the west, subsided 0.40 and $0.35 \mathrm{ft}$ from 1970 to 1978 . Bench marks 256.12B and $256.56 \mathrm{~B}$, in the aqueduct lining to the east, subsided 0.55 and $1.01 \mathrm{ft}$ from 1970 to 1978 . The large change at mile 255.77 appears to be due partly to hydrocompaction and partly to structure settlement (note that the preconsolidated area started at mile 255.75). The undulating subsidence in this 7-mi reach from aqueduct mile 254 to mile 261 is attributed to hydrocompaction that has occurred since 1970 leveling.

The reach from mile 261 to mile 274 is out of the known hydrocompaction area and in the area of regional subsidence due to fluid withdrawal. Subsidence from mile 261 to mile 270 ranged from less than $0.2 \mathrm{ft}$ to $0.4 \mathrm{ft}$, then reached $0.9 \mathrm{ft}$ at mile 271.5 from 1970 to 1978 .

Field extensometer 11N/21W-3B1 (fig. 66; see fig. 40 for location), approximately $1 \mathrm{mi}$ north of the aqueduct at mile 272 , recorded $1.84 \mathrm{ft}$ of compaction versus $2.05 \mathrm{ft}$ of subsidence (90 percent) from February 1965 to March 9 , $1970,0.57 \mathrm{ft}$ of compaction versus $0.61 \mathrm{ft}$ of subsidence (93 percent) from March 9, 1970, to May 3, 1975, and 0.45 $\mathrm{ft}$ of compaction versus $0.61 \mathrm{ft}$ of subsidence ( 73 percent) from May 3, 1975, to August 17, 1978.

This extensometer well is $1,480 \mathrm{ft}$ deep and measures most of the aquifer compaction due to ground-water pumping. The site was disturbed in early 1978 at about the time of the 1978 leveling. The concrete base that is the reference for all measurements had been undermined by water; however, repairs were made and the site restored. The aqueduct subsidence at bench marks $272.00 \mathrm{~B}$ and $272.39 \mathrm{~A}$ (not shown on pl. 1), approximately $1 \mathrm{mi}$ south, was $0.31 \mathrm{ft}$ from 1975 to 1978 , suggesting a minor data problem at the extensometer site. Extensometer data (tables 3 and 6) confirm that the measured compaction at well 3B1 from 1970 to 1978 was equal to 83 percent of the subsidence and that most of the subsidence from 1975 to 1978 occurred during the 1976-77 drought years.

Erratic subsidence is demonstrated at bench mark 273.48A. This bench mark located in a concrete overchute subsided $1.12 \mathrm{ft}$ from 1970 to 1975 and $0.63 \mathrm{ft}$ from 1975 to 1978 (pl. 1). Bench mark 273.09A, not shown but in the aqueduct lining about $0.4 \mathrm{mi}$ northwest of bench mark $273.48 \mathrm{~A}$, subsided $0.44 \mathrm{ft}$ from 1970 to 1975 and $0.24 \mathrm{ft}$ from 1975 to 1978 . Bench mark 273.75B, in the aqueduct lining $0.27 \mathrm{mi}$ southeast of bench mark $273.48 \mathrm{~A}$, subsided $0.38 \mathrm{ft}$ from 1970 to 1975 and $0.20 \mathrm{ft}$ from 1975 to 1978. Other bench marks in this area, not plotted on plate 1 , also show erratic change, suggesting possible hydrocompaction, or structure settlement, or both.

Another known hydrocompaction area, mile 274 to mile 280.5, is also in the area of subsidence due to fluid withdrawal. Maximum subsidence was $1.1 \mathrm{ft}$ near mile 275 and $0.9 \mathrm{ft}$ at mile 277 . The settlement in this $6-\mathrm{mi}$ reach is caused by both subsidence due to fluid withdrawal and subsidence due to hydrocompaction, chiefly the latter. Subsidence from mile 280.5 to 287 ranged from $0.2 \mathrm{ft}$ at mile 280 to about $0.4 \mathrm{ft}$ at mile 282 , then decreased to about $0.1 \mathrm{ft}$ at mile 287 . The southernmost known hydrocompaction area shows no continued hydrocompaction.

ELK HILLS LEVELING

The line of levels (Elk Hills loop) that runs through the Elk Hills from the California Aqueduct at mile 229.7 


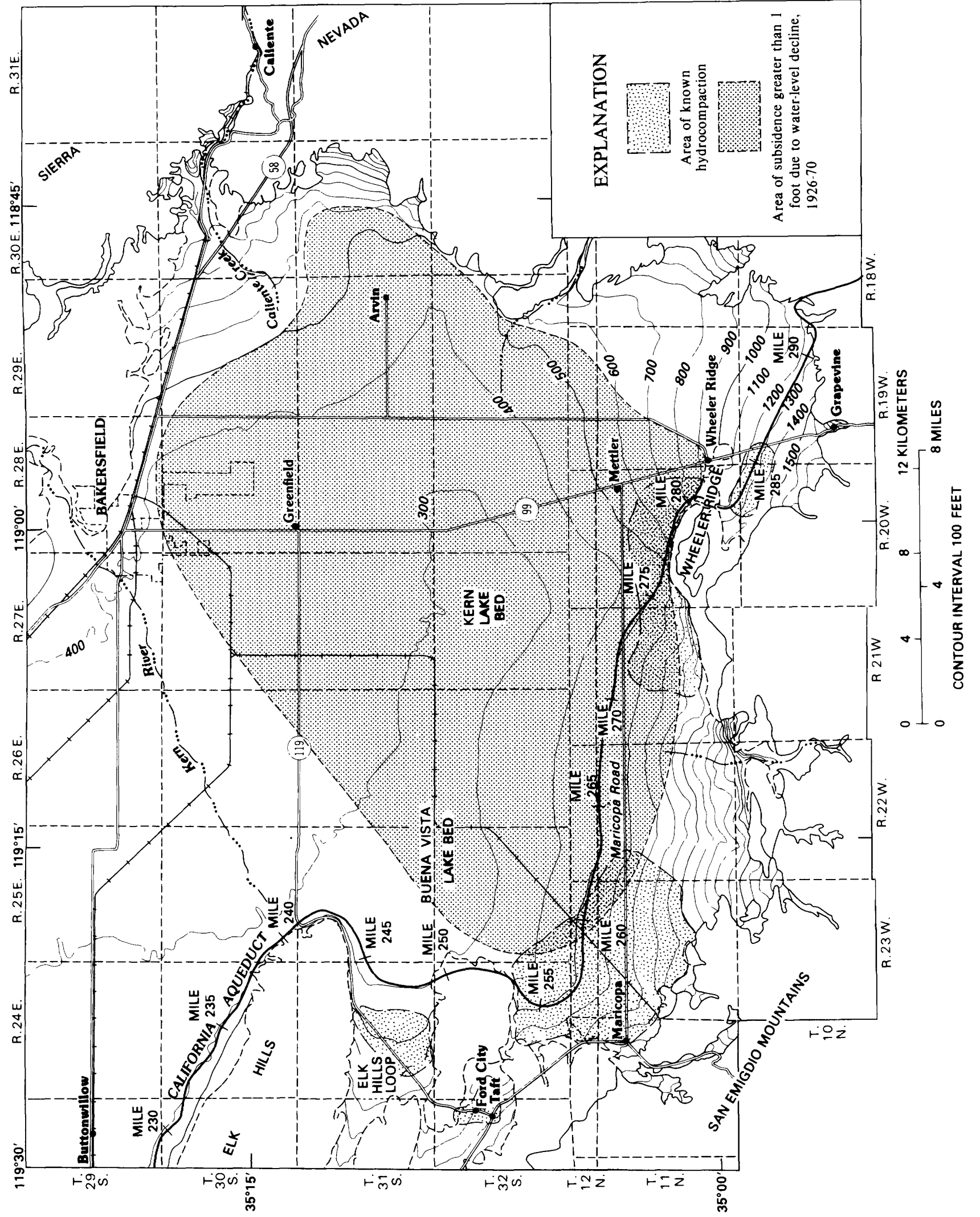


and ties back to the California Aqueduct at mile 245.09 was first run in 1964 (see fig. 30 for location). This line was releveled in 1975 by the National Geodetic Survey and again in 1978 by the California Department of Water Resources. Maximum subsidence from 1964 to 1978 was at bench marks Y548 $(0.83 \mathrm{ft})$ and $230+00$ POT CSHD (1.02 ft) (see fig. 30 for location). The above bench marks are at Buena Vista oilfield. Other bench marks in the Elk Hills area show a subsidence of $0.20-0.30 \mathrm{ft}$ from 1964 to 1978.

\section{MONITORING OF COMPACTION AND CHANGE IN HEAD}

Two principal objectives of the cooperative program with the California Department of Water Resources on land-subsidence studies, and essential elements of the Federal program on mechanics of aquifer systems, are to determine the depth interval(s) in which compaction is occurring and to measure the magnitude and time distribution of the compaction where possible. Such information, together with periodic measurement of land subsidence as determined by spirit-level surveys to surface bench marks, is essential for determining the cause of subsidence and for monitoring the magnitude and the change in rate of subsidence. When coupled with measurement of water level or head change in the stressed aquifer systems, these supply the data required for stresscompaction or stress-strain analysis.

Since 1955, the Geological Survey has monitored aquifer-system compaction in the San Joaquin Valley by means of borehole extensometers. At present two types of extensometers are in use in 25 wells at 18 compaction and water-level monitoring sites (see fig. 40 for location). Of these, 20 are of the original taut-cable design described by Lofgren (1961, p. B49-B51 and figs. 24.1, 24.2) and 5 are of a newer design that uses a free-standing pipe.

The cable and the free-standing pipe extensometers (fig. 39) are similar in basic concept. In the cable type, an anchor weight is attached to the extensometer cable, lowered into the well, and set below the bottom of the well casing. This anchor acts as a depth bench mark. The extensometer cable is maintained under (ideally) constant tension by a counterweight at the land surface. As the aquifer system compacts, an equivalent length of cable apparently emerges from the well; this movement is measured by a mechanical recorder attached to the compaction cable at the land surface. In the free-standing pipe extensometer, the pipe is lowered into the well and set below the bottom of the well casing. A mechanical recorder attached to the extensometer pipe measures the movement of the land surface relative to the nonmoving pipe and thus measures the compaction or expansion of the aquifer system.
The accuracy of the compaction record is dependent largely on the ability of the extensometer (cable or pipe) to maintain an invariant length between the bottom-hole reference point ("depth bench mark") and the aboveground reference point (fig. 39). Typically this ability is more or less degraded by frictional coupling between the ideally motionless extensometer cable or pipe and the deforming well casing, which shortens and moves downward in the grip of the compacting sediments. Because of its vastly greater cross section, the pipe extensometer is more competent than the cable to resist frictionally induced length changes. Accordingly, it generally produces a better record in typical wells of moderate depth. It should be noted, however, that many other factors beyond the scope of this discussion need to be considered in selecting an extensometer design for a specific installation.

At the present time, 9 of the extensometers in the San Joaquin Valley are equipped with continuous recorders and 16 are visually read periodically. Of the 25 extensometers, only 10 are deep enough to measure a large percentage of the aquifer-system compaction. Other sites supply measurements of compaction representing variable percentages (generally less than 60 percent) of total subsidence (table 6).

Continuous or periodic water-level measurements are also necessary in a subsidence-monitoring program in order to define the cause-and-effect relationships of the subsidence process. Of the 24 water-level monitoring wells collocated with the extensometers, 18 are equipped with continuous recorders and 6 are measured periodically. In order to produce reliable stress-strain or stresscompaction plots that can be utilized to derive recoverable and nonrecoverable storage (compressibility) and permeability parameters (Riley, 1969), water-level measurements must represent the average change in stress in the compacting interval being measured. Seven of the extensometer/water-level observation-well pairs furnish stress-compaction plots that are adequate to derive useful aquifer-system data.

In addition to defining aquifer-system characteristics and response to pumping stress at specific locations, the compaction and water-level monitors serve as indicators of regional subsidence rates and supply observers with data to use in deciding when areal releveling is needed.

Some of the wells used for extensometer and waterlevel monitors are former irrigation wells converted to observation wells. Others were drilled and completed specifically for the monitoring program. Many of the former irrigation wells are 20 or more years old and have been subjected to many feet of compaction. The wells whose well casings have failed and will continue to fail because of casing compression caused by compaction of the aqui- 
fer system are lost for extensometer and water-level measurements. Five wells drilled specifically for extensometer installation were constructed with down-hole slip-joints to allow for casing shortening; this kind of well construction helps to extend the life of the well.

The location of 18 well sites where water-level changes and compaction of the water-bearing deposits are currently being measured and six sites that have been abandoned since 1970 are shown on figure 40 .
Table 3 summarizes the net annual compaction or expansion (negative compaction) at each site through 1979 and also gives compaction or expansion in six additional depth intervals defined by multiple-depth installations. For example, at $12 / 12-16 \mathrm{H}$, wells $\mathrm{H} 2, \mathrm{H} 3$, and $\mathrm{H} 4$ are, respectively, $1,000,350$, and $500 \mathrm{ft}$ deep. The extensometer in well $\mathrm{H} 2$ records total compaction from land surface to the 1,000-ft depth, and the extensometer in $\mathrm{H} 4$ measures the compaction from land surface to the $500-\mathrm{ft}$ depth. By

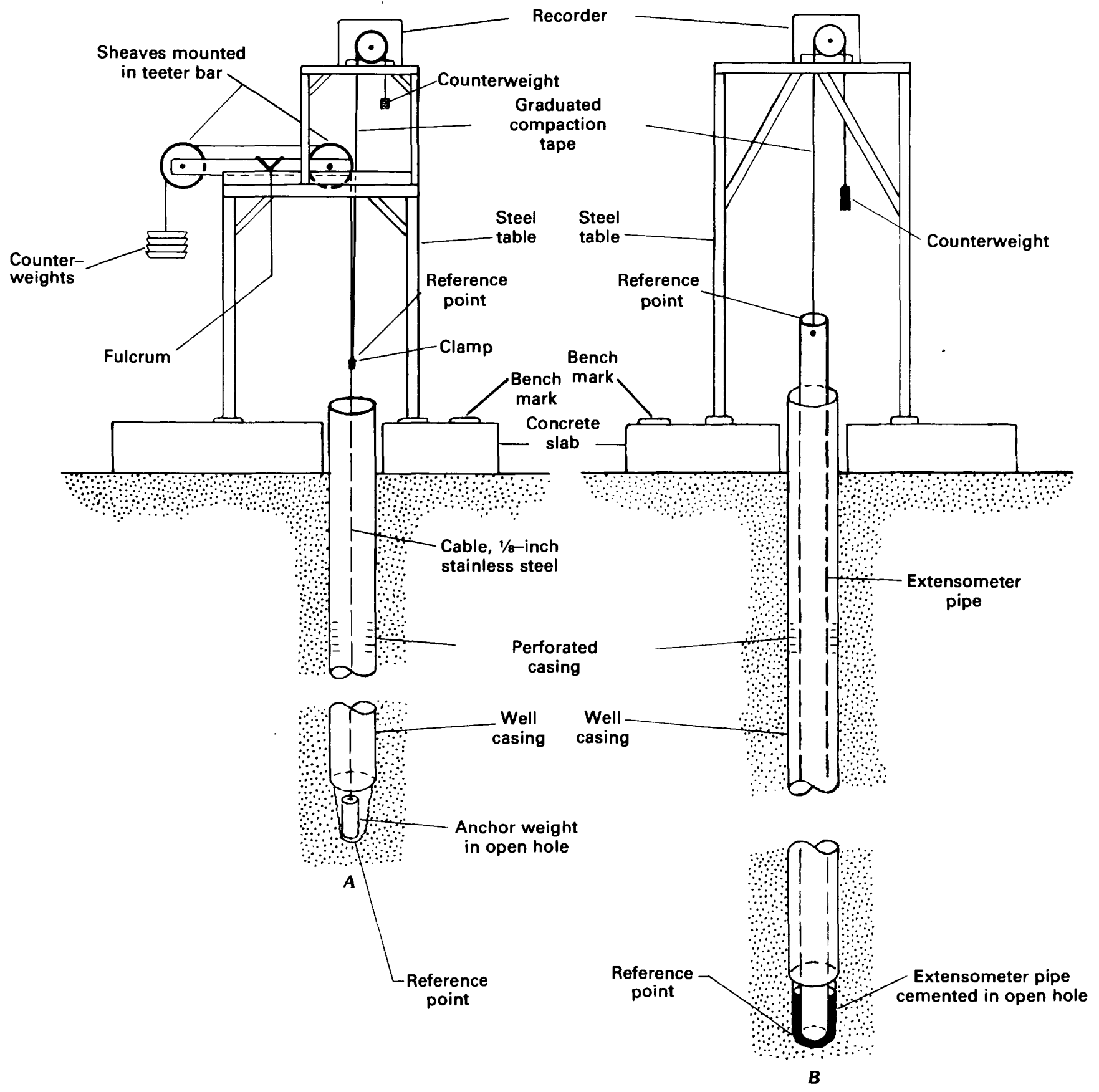

FIGURE 39.-Recording extensometer installations. $A$, the cable and $B$, free-standing pipe extensometers. 
subtracting the compaction in $\mathrm{H} 4$ from that in $\mathrm{H} 2$, the September 1958 through 1979 occurred at well 16/15compaction of the 500- to $1,000-\mathrm{ft}$ depth interval is $34 \mathrm{~N} 1$ (fig. 49). The well is $2,000 \mathrm{ft}$ deep and is adjacent to calculated.

The maximum recorded compaction of $11.69 \mathrm{ft}$ from the California Aqueduct in the joint-use reach in western Fresno County.

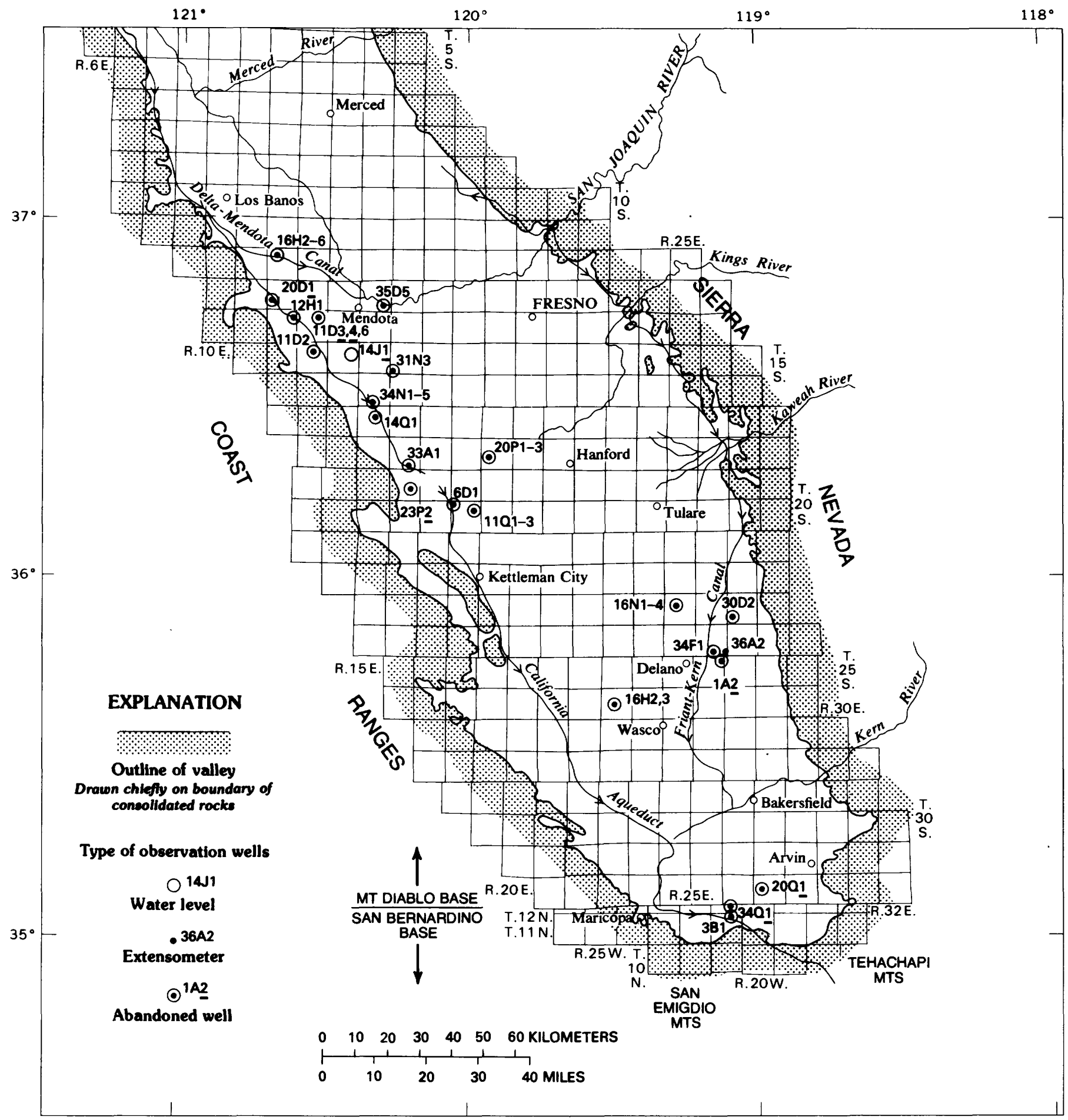

FIGURE 40.-Location of water-level and compaction measuring sites. Base from U.S. Geological Survey, 1:1,000,000, State of California map, 1940. 
TABLE 3.-Annual compaction at compaction-

[In order to arrive at consistent sums, the amount of annual compaction is shown are not accurate to less than

\begin{tabular}{|c|c|c|c|c|c|c|c|c|c|c|c|}
\hline $\begin{array}{l}\text { Well } \\
\text { No. }\end{array}$ & $\begin{array}{l}\text { Anchor depth } \\
\text { when installed } \\
\text { (ft) }\end{array}$ & $\begin{array}{c}\text { Depth } \\
\text { interval } \\
\text { (ft) }\end{array}$ & $\begin{array}{l}\text { Start of } \\
\text { record } 1\end{array}$ & 1958 & 1959 & 1960 & 1961 & 1962 & 1963 & 1964 & 1965 \\
\hline & & & & & & & & & & & Los Banos- \\
\hline $12 / 12-16 \mathrm{H} 3 . . . .$. & 350 & $0-350$ & $5 / 19 / 58$ & 0.052 & 0.053 & -0.004 & 0.013 & 0.036 & 0.005 & 0.008 & 0.007 \\
\hline $16 \mathrm{H} 4 \ldots \ldots$ & 500 & $350-500$ & $5 / 19 / 58$ & .032 & .087 & .019 & .002 & .008 & .003 & .011 & .013 \\
\hline $16 \mathrm{H} 2 \ldots \ldots$ & 1,000 & $500-1,000$ & $5 / 19 / 58$ & .211 & .302 & .293 & .325 & .158 & .187 & .173 & .066 \\
\hline $16 \mathrm{H} 2$ & 1,000 & $0-1,000$ & $5 / 19 / 58$ & .295 & .442 & .308 & .340 & .202 & .195 & .192 & .086 \\
\hline $13 / 12-20 \mathrm{D} 1 . \ldots \ldots$ & 681 & 0.681 & $10 / 10 / 61$ & $\ldots$. & $\ldots$. & $\ldots . .$. & .077 & .340 & .215 & .119 & .182 \\
\hline 13/15-35D5_...... & 440 & $0-440$ & $5 / 13 / 66$ & $\ldots$ & $\ldots$ & $\ldots . .$. & ..... & $\ldots .$. & $\ldots$. & $\ldots$. & ..... \\
\hline $14 / 12-12 \mathrm{H} 1 \ldots \ldots$. & 913 & $0-913$ & $1 / 10 / 65$ & $\ldots$ & $\ldots$ & (n...... & .... & & & & .414 \\
\hline $14 / 13-11 \mathrm{D} 4 \ldots \ldots$ & 780 & $0-780$ & $1 / 1 / 61$ & $\ldots$ & $\ldots$ & (n........ & .310 & .196 & .222 & .199 & .108 \\
\hline $11 \mathrm{D} 6$ & 1,358 & $780-1,358$ & $5 / 25 / 61$ & $\ldots$ & $\ldots$ & $\ldots$ & .354 & .462 & .259 & .400 & .322 \\
\hline $11 \mathrm{D} 6 \ldots$ & 1,358 & $0-1,358$ & $5 / 25 / 61$ & $\ldots$ & $\ldots$ & (......... & .480 & .658 & .481 & .599 & .430 \\
\hline $15 / 13-11 \mathrm{D} 2 \ldots \ldots$ & 958 & $0-958$ & $1 / 11 / 65$ & $\cdots$ & $\ldots$ & (n...... & $\ldots .$. & $\ldots .$. & $\ldots$. & $\ldots$. & .204 \\
\hline $15 / 16-31 N 3 . \ldots \ldots$ & 596 & 0- 596 & $3 / 23 / 67$ & $\cdots$ & $\ldots$ & $\ldots$ & $\ldots$ & $\ldots$ & $\ldots$ & $\ldots \ldots$ & $\ldots .$. \\
\hline $16 / 15-34 N 3 \ldots \ldots$ & 503 & $0-503$ & $9 / 25 / 58$ & .010 & .118 & .093 & .087 & .138 & .082 & .096 & .082 \\
\hline $34 \mathrm{~N} 2 \ldots \ldots$ & 703 & 503- 703 & $9 / 25 / 58$ & .094 & .232 & .123 & .191 & .167 & .172 & .174 & .104 \\
\hline $34 \mathrm{~N} 1 .$. & 2,000 & $703-2,000$ & $9 / 25 / 58$ & .286 & .857 & .717 & .867 & .697 & .710 & .829 & .634 \\
\hline $34 \mathrm{~N} 1$. & 2,000 & $0-2,000$ & $9 / 25 / 58$ & .390 & 1.207 & .933 & 1.145 & 1.002 & .964 & 1.099 & .820 \\
\hline $34 \mathrm{~N} 4 \ldots \ldots$ & 1,096 & $0 \cdot 1,096$ & $8 / 16 / 60$ & $\ldots . .$. & $\ldots$ & .232 & .661 & .648 & 5.416 & $\ldots$. & \\
\hline $34 \mathrm{~N} 46 \ldots \ldots$ & 900 & $0-900$ & $9 / 15 / 64$ & $\ldots$ & .... & ...... & $\ldots .$. & $\ldots .$. & $\ldots .$. & $\ldots$ & .358 \\
\hline $17 / 15-14 Q 1 \ldots \ldots$ & 2,315 & $0-2,315$ & $11 / 4 / 69$ & - . . & $\ldots$ & (n..... & $\ldots$ & $\ldots$ & $\ldots$ & $\ldots$ & $\ldots$ \\
\hline $18 / 16-33 A 1 . \ldots \ldots$ & 1,029 & $0-1,029$ & $3 / 10 / 65$ & $\ldots$. & & $\ldots$ & $\ldots$ & $\ldots$ & $\ldots$ & & .128 \\
\hline 18/19-20P2 ....... & 578 & 0.578 & $3 / 24 / 67$ & $\cdots$ & $\ldots$ & 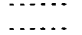 & $\ldots$ & $\ldots$ & $\ldots$ & $\cdots$ & $\ldots$. \\
\hline 19/16-23P2 ........ & 2,200 & $0-2,200$ & $1 / 2 / 60$ & $\ldots$ & $\ldots$ & .508 & .660 & .553 & .378 & .424 & .259 \\
\hline $20 / 18-6 \mathrm{D} 1 \ldots \ldots$. & 867 & $0-867$ & $1 / 11 / 65$ & ..... & ..... & $\ldots \ldots$ & $\ldots .$. & $\ldots .$. & ..... & $\ldots$. & .273 \\
\hline $11 Q 1 \ldots \ldots$ & 710 & $0 \cdot 710$ & $7 / 24 / 64$ & $\ldots \ldots$ & $\ldots \ldots$ & $\ldots . .$. & $\ldots .$. & $\ldots .$. & $\ldots$. & .115 & .259 \\
\hline $11 \mathrm{Q} 2^{6}$ & 845 & $0-845$ & $2 / 27 / 63$ & $\ldots$ & $\ldots$ & - & .... & $\ldots$ & .230 & .330 & .300 \\
\hline $11 \mathrm{Q} 2 \ldots \ldots$ & 845 & $710-845$ & $7 / 24 / 64$ & $\ldots$ & $\ldots$ & $\ldots$ & $\ldots$ & ..... & . . . . . & .025 & .041 \\
\hline $11 \mathrm{Q} 3 \ldots \ldots$ & 1,930 & $845-1,930$ & $2 / 27 / 63$ & $\ldots$ & $\ldots$ & $\ldots$ & $\ldots$ & $\ldots$. & .261 & .212 & .357 \\
\hline \multirow[t]{2}{*}{$11 \mathrm{Q3} \ldots \ldots$} & 1,930 & $0-1,930$ & $1 / 1 / 63$ & $\ldots$ & $\ldots$ & (n...... & $\ldots$ & $\ldots$ & .611 & .542 & 4.657 \\
\hline & & & & & & & & & & & Tulare- \\
\hline $22 / 27-30 \mathrm{D} 2 \ldots$ & 1,246 & $0-1,246$ & $8 / 13 / 70$ & $\ldots$ & & & & & & & \\
\hline $23 / 25-16 \mathrm{~N} 4$ & 250 & $0-\quad 250$ & $6 / 24 / 59$ & $\ldots$ & 0.005 & 0.024 & 0.024 & 0.008 & 0.007 & 0.022 & 0.009 \\
\hline $16 N 3$ & 430 & $250-430$ & $6 / 24 / 59$ & $\ldots$ & .055 & .100 & .062 & .120 & .042 & .080 & .048 \\
\hline $16 \mathrm{~N} 1 \ldots . .$. & 760 & $430-760$ & $6 / 24 / 59$ & $\ldots$ & .184 & .433 & .473 & .051 & .056 & .253 & .131 \\
\hline $16 \mathrm{~N} 1 \ldots \ldots$ & 760 & 0- 760 & $4 / 18 / 58$ & 0.454 & .482 & .557 & .559 & .179 & .105 & .355 & .188 \\
\hline $24 / 26-34 \mathrm{~F} 1 \ldots \ldots \ldots$ & 1,510 & $0-1,510$ & $1 / 21 / 59$ & $\ldots$ & .242 & .100 & .111 & -.051 & .018 & .063 & -.025 \\
\hline $36 \mathrm{A2}$ & 2,200 & $0-2,200$ & $5 / 12 / 59$ & $\ldots$ & .059 & .342 & 4.333 & +059 & .096 & .329 & .062 \\
\hline 25/26-1 A2 & 892 & $0-892$ & $4 / 6 / 59$ & $\ldots$ & .058 & .061 & .059 & -.013 & -.004 & .050 & -.003 \\
\hline $26 / 23-16 \mathrm{H} 3 . \ldots$. & 355 & $0-\quad 355$ & $8 / 17 / 78$ & . & $\ldots . .$. & ...... & $\ldots . .$. & $\ldots .$. & ..... & ..... & $\ldots$. \\
\hline $16 \mathrm{H} 2 \ldots$ & 1,002 & $355-1,002$ & $8 / 17 / 78$ & $\ldots$ & $\ldots$ & $\ldots$ & .... & $\ldots$ & $\ldots$ & $\ldots$. & $\ldots$. \\
\hline \multirow[t]{2}{*}{$16 \mathrm{H} 2 \ldots \ldots$} & 1,002 & $0-1,002$ & $8 / 17 / 78$ & $\ldots$ & $\ldots$. & $\ldots$. & $\ldots$. & $\ldots \ldots$ & $\ldots$. & $\ldots$. & $\ldots$. \\
\hline & & & & & & & & & & & Arvin- \\
\hline 32/28-20Q1.. & 970 & 0- 970 & $4 / 11 / 63$ & $\ldots$ & $\ldots . .$. & & & & 0.192 & 0.365 & 0.178 \\
\hline $12 \mathrm{~N} / 21 \mathrm{~W}-34 \mathrm{Q} 1 \ldots$ & 810 & $0-810$ & $6 / 2 / 60$ & . & ...... & 0.207 & 0.326 & 0.271 & .209 & .186 & .266 \\
\hline $11 \mathrm{~N} / 21 \mathrm{~W} \cdot 3 \mathrm{~B} 1 \ldots$ & 1,480 & $810-1,480$ & $4 / 12 / 63$ & ..... & - & $\ldots \ldots$ & $\ldots .$. & $\ldots .$. & .188 & .261 & .135 \\
\hline $11 \mathrm{~N} / 21 \mathrm{~W}-3 \mathrm{~B} 1 \ldots .$. & 1,480 & $0-1,480$ & $4 / 12 / 63$ & $\ldots$ & $\ldots$ & (n....... & $\ldots$ & $\ldots$ & .326 & .447 & .401 \\
\hline
\end{tabular}

\section{COMPUTER SIMULATION OF AQUIFER-SYSTEM COMPACTION}

Continuous or frequent measurements of head change were shown by Helm $(1975,1976,1977$, and 1978) to provide input data required for remarkably accurate computer simulation of the subsidence process at seven monitoring sites in the San Joaquin Valley and seven in the Santa Clara Valley, Calif. The simulation, based on soil consolidation theory, uses the time-varying boundary stresses defined by the water-level records, data on the number and thickness of compressible aquitards in the compacting aquifer system, and preliminary values of aquitard permeability and compressibility (recoverable and nonrecoverable). These aquitard properties may be derived initially by Riley's (1969) graphical analysis of stress-strain plots, where appropriate extensometer data are available, or may be based on laboratory tests, or simply may be estimated from geologic considerations. Trial-and-error comparisons of the calculated compaction history with the known history defined by extensometer (and (or) leveling) data result in progressive refinement of the estimated aquitard parameters and, typically, a very good final match between observed and 
measuring sites, San Joaquin Valley

to a thousandth of a foot; however, many of the measured yearly values

a few hundredths of a foot. Minus (-) indicates expansion.]

\begin{tabular}{|c|c|c|c|c|c|c|c|c|c|c|c|c|c|c|}
\hline 1966 & 1967 & 1968 & 1969 & 1970 & 1971 & 1972 & 1973 & 1974 & 1975 & 1976 & 1977 & 1978 & 1979 & $\begin{array}{l}\text { Total } \\
\text { measured } \\
\text { compaction } \\
\text { (ft) }\end{array}$ \\
\hline \multicolumn{15}{|c|}{ Kettleman City Area } \\
\hline 0.002 & 0.004 & 0.002 & 0 & 0.002 & 0 & 0 & -0.001 & 0 & -0.001 & 0.004 & 0.013 & 0 & 0 & 0.195 \\
\hline .011 & .013 & .015 & .008 & .007 & .013 & .007 & .016 & .001 & .002 & ${ }^{2} .005$ & ......... & .... & $\ldots . .$. & .273 \\
\hline .125 & .105 & .075 & .060 & .060 & .050 & .039 & .020 & .034 & .026 & $\ldots$ & $\ldots . .$. & $\ldots$ & $\ldots \ldots$ & 2.289 \\
\hline .138 & .122 & .092 & .068 & .069 & .063 & .046 & .035 & .035 & .027 & .045 & .096 & .032 & .027 & 2.955 \\
\hline .120 & .094 & .074 & .056 & .032 & .038 & .070 & .024 & ${ }^{3} .030$ & & & & $\ldots$ & ........ & 1.471 \\
\hline-.022 & .014 & .022 & .006 & .034 & .050 & .015 & .025 & .029 & .024 & .025 & .024 & .001 & .008 & .255 \\
\hline .336 & .239 & .139 & .097 & .164 & .100 & .083 & .085 & .099 & .067 & .058 & .132 & .019 & .015 & 2.047 \\
\hline .194 & .160 & .071 & .001 & .013 & .013 & .007 & .014 & 3.032 & ..... & .... & . . . . . . & .... & $\ldots .$. & 1.540 \\
\hline .279 & .326 & .157 & .073 & .078 & .057 & .036 & .016 & .020 & $\ldots$. & $\ldots \ldots$ & ....... & & & 2.839 \\
\hline .473 & .486 & .228 & .074 & .091 & .070 & .043 & .030 & .052 & .017 & .039 & .180 & -.074 & -.010 & 4.347 \\
\hline \multirow[t]{2}{*}{.154} & .126 & .099 & .060 & .047 & .022 & .024 & .006 & 0 & .002 & -.009 & .069 & -.012 & -.022 & .770 \\
\hline & .088 & .120 & .092 & .032 & .055 & .001 & .045 & .097 & -.006 & .001 & .082 & -.038 & -.017 & .552 \\
\hline .085 & .090 & .101 & .130 & .112 & .104 & .051 & .061 & .040 & .058 & .023 & .051 & .013 & 0 & 1.625 \\
\hline .104 & .122 & .118 & .046 & .077 & .040 & .031 & -.010 & -.004 & -.037 & -.004 & .073 & -.020 & .018 & 1.811 \\
\hline .614 & .604 & .573 & .312 & .202 & .108 & .001 & -.006 & -.003 & -.029 & -.011 & .298 & $4-.051$ & -.010 & 8.199 \\
\hline \multirow[t]{2}{*}{.803} & .816 & .792 & .488 & .391 & .252 & .083 & .045 & .033 & -.008 & .008 & .422 & -.058 & .008 & 11.635 \\
\hline & & & & & & & & & & & & & & 1.957 \\
\hline \multirow[t]{2}{*}{.320} & .340 & .334 & .233 & .210 & .231 & .075 & .017 & 7.027 & ........ & $\ldots$ & . . . . . & $\ldots$ & .... & 2.145 \\
\hline & & & .079 & .478 & .225 & .088 & .013 & -.032 & -.054 & -.009 & .542 & ${ }^{\mathrm{N}}-.199$ & 0 & 1.131 \\
\hline \multirow[t]{2}{*}{.210} & .186 & .124 & .034 & .094 & .060 & .073 & .023 & .036 & .009 & .004 & .099 & -.004 & -.013 & 1.063 \\
\hline & .026 & .070 & .036 & .065 & .082 & .065 & .014 & -.019 & .026 & .018 & .121 & -.035 & .014 & .483 \\
\hline .552 & .355 & .328 & .201 & .192 & .143 & .198 & .029 & 9.097 & & & & & & 4.877 \\
\hline .267 & .280 & .179 & .090 & .121 & .074 & .044 & .030 & -.019 & .018 & -.006 & .189 & -.093 & ${ }^{10} .022$ & 1.469 \\
\hline .240 & .225 & .224 & .149 & .145 & .117 & .093 & .034 & -.016 & .012 & -.016 & .179 & -.025 & -.019 & 1.716 \\
\hline .330 & .290 & .280 & .220 & .190 & .147 & .090 & .019 & -.023 & -.004 & -.019 & .247 & -.053 & -.021 & 2.553 \\
\hline .090 & .065 & .056 & .071 & .045 & .030 & -.003 & -.015 & -.007 & -.016 & -.003 & .068 & -.028 & -.002 & .417 \\
\hline .240 & .199 & .259 & .207 & .160 & ${ }^{11} .133$ & .026 & -.006 & -.092 & -.039 & .007 & .308 & -.105 & -.083 & 2.044 \\
\hline${ }^{ \pm .570}$ & .489 & .539 & .427 & .350 & ${ }^{11} .280$ & .116 & .013 & $4-.115$ & -.043 & -.012 & .555 & -.158 & -.104 & 4.717 \\
\hline \multicolumn{15}{|c|}{ Wasco Area } \\
\hline & & & & -0.034 & 0.124 & 0.316 & 0.075 & 0.093 & 0.086 & 0.219 & 0.248 & 0.028 & 0.046 & 1.201 \\
\hline 0.001 & 0 & 0.003 & -0.002 & 0 & .007 & .004 & -.002 & -.002 & .001 & .003 & .010 & -.003 & 0 & .119 \\
\hline .085 & .003 & .057 & .005 & .033 & .022 & .058 & .005 & .016 & .019 & .039 & .053 & -.014 & .014 & .902 \\
\hline .225 & .063 & .160 & .036 & .100 & .075 & .143 & .037 & .041 & .055 & .111 & .146 & .019 & .023 & 2.815 \\
\hline .311 & .066 & .220 & .039 & .133 & .104 & .205 & .040 & .055 & .075 & .153 & .209 & .002 & .037 & 4.528 \\
\hline .068 & -.031 & .038 & -.057 & .038 & -.009 & .023 & -.028 & -.013 & .002 & .068 & .111 & -.098 & -.034 & .536 \\
\hline 4.145 & -.045 & .168 & -.060 & .143 & .012 & .118 & -.016 & .089 & .017 & .196 & .339 & -.175 & -.002 & 2.031 \\
\hline .096 & -.012 & .018 & -.001 & .014 & -.005 & .011 & -.010 & -.001 & -.016 & .017 & ${ }^{12} .011$ & & & .330 \\
\hline$\ldots$. & $\ldots$. & $\ldots$ & ...... & $\ldots$. & ....... & $\ldots$. & ...... & $\ldots$. & ..... & $\ldots$. & ....... & -.021 & .002 & -.019 \\
\hline$\ldots$. & $\ldots$. & $\ldots$. & ..... & $\ldots$. & ..... & $\ldots$. & .... & $\ldots$ & . & $\ldots$. & . . . . . & -.066 & .038 & -.028 \\
\hline$\cdots$ & $\ldots$. & .... & ...... & $\ldots$. & ....... & $\ldots$ & ...... & $\ldots$. & ...... & $\ldots$. & & -.087 & .040 & -.047 \\
\hline \multicolumn{15}{|c|}{ Maricopa Area } \\
\hline 0.255 & 0.219 & 0.124 & 0.124 & 0.095 & 0.091 & 0.096 & 0.060 & 0.104 & 0.066 & 0.040 & ${ }^{12} 0.068$ & .... & $\ldots \ldots$ & 2.047 \\
\hline .197 & .130 & .014 & .186 & .153 & .060 & .070 & .062 & ${ }^{13} .065$ & ..... & $\ldots$. & ....... & $\ldots$. & ...... & 2.402 \\
\hline .229 & .184 & .344 & .152 & .149 & -.001 & .011 & .016 & .065 & . & $\ldots$ & ...... & $\ldots \ldots$ & ...... & 1.733 \\
\hline .426 & .314 & .358 & .338 & .302 & .059 & .081 & .078 & .130 & .086 & .154 & .225 & ${ }^{4}-.016$ & .024 & 3.733 \\
\hline \multicolumn{15}{|c|}{$\begin{array}{l}8 \text { Flooded in } 1978 . \\
9 \text { Site discontinued September } 25,1974 . \\
{ }^{10} \text { Site temporarily out, November } 11,1979 \text {. } \\
11 \text { Data adjustment, } 1971 \text { annual compacti } \\
{ }^{12} \text { Site discontinued } 1978 . \\
{ }^{13} \text { Site discontinued September } 19,1974 .\end{array}$} \\
\hline
\end{tabular}

calculated compaction. Helm (1977) has shown that constant values of aquitard parameters derived from a few years of paired extensometer and water-level data can be used to predict total compaction with reasonable accuracy over periods of several decades.

Helm (1978) tabulated significant parameters derived from the application of his aquitard compaction model to data recorded at seven compaction and waterlevel monitoring sites in the San Joaquin Valley. These modeling results, with some modifications and deletions, are presented here in table 4, together with additional material inferred from the modeling results and related data. Helm's model ascribes all observed deformation of the aquifer system to compaction and expansion of the aquitards. Under conditions of virgin compaction at stresses greater than the maximum past stress, the compressibility of the aquitards so vastly exceeds that of the aquifers (by two or three orders of magnitude) that the error introduced by this assumption is wholly insignificant. However, if stress increases induced by water-level declines do not exceed the maximum past stress, the resulting elastic responses of the permeable sands (aquifers) in the aquifer system may contribute significantly to the total deformation recorded by the borehole extensometers. In addition, at stresses less than maximum past stress, the relatively small elastic compressibility of 


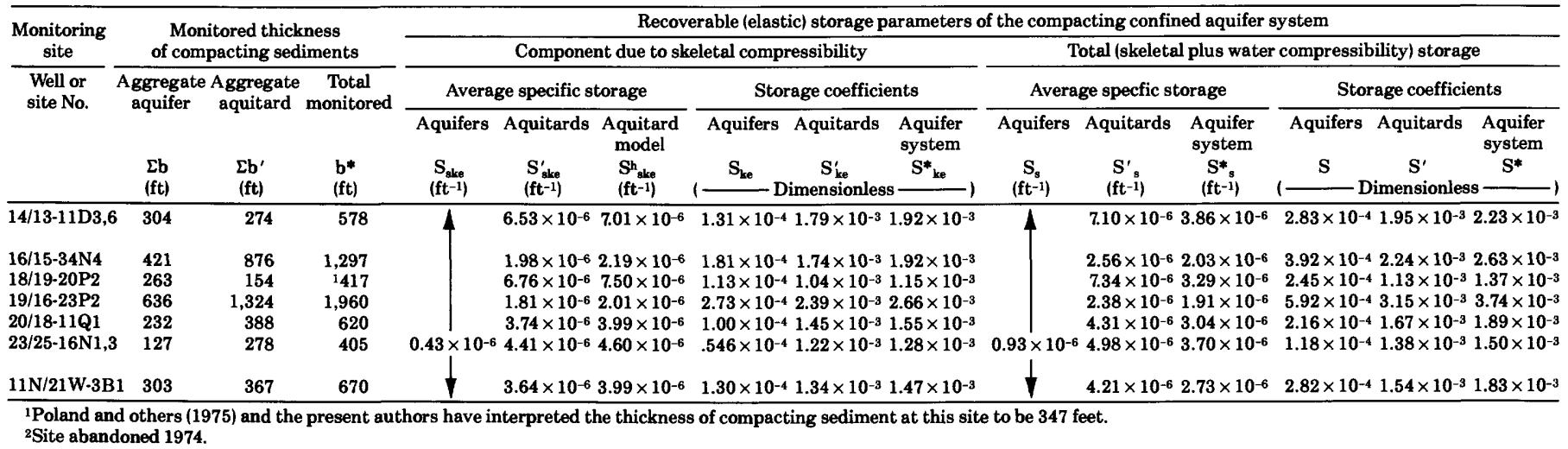

the aquifers and aquitards allows the compressibility of the pore water to assume a significant role in the total specific storage of the aquifers, and to a lesser extent of the aquitards.

In recognition of these considerations, an attempt has been made to estimate the elastic storage parameters for aquifer and aquitard materials. The procedure involves splitting the skeletal component of the aquifersystem storage coefficient, $\left(\mathbf{S}_{\mathrm{ke}}^{*}\right)$-derived directly from extensometer data by Riley's (1969) method of stressstrain analysis-into components attributable to the aggregate thickness of aquifers and the aggregate thickness of aquitards. The only data available on skeletal compressibility of the aquifers is inferred from the hydraulic response observed during pumping tests at the Pixley monitoring site (23/25-16N) as reported by Riley and McClelland (1972). For purposes of estimation a representative value of aquifer specific storage $0.93 \times 10^{-6} \mathrm{ft}^{-1}$ was selected from the range of probable values reported by Riley and McClelland. Assuming a porosity of 0.35 , the value of the skeletal specific storage for the aquifers at Pixley was calculated to be $0.43 \times 10^{-6} \mathrm{ft}^{-1}$. This value of volumetric compressibility has been used to estimate the contribution of the aquifers to the total elastic deformation observed at all sites in the San Joaquin Valley. In the absence of site-specific data on the horizontal strain associated with pumping, we have assumed that the entire volumetric strain inferred from hydraulic response is reflected in a vertical thickness change of the aquifers. This procedure probably tends to overestimate somewhat the contribution of the aquifers to the elastic deformations recorded by the vertical extensometers.

The contribution of aquitard compaction and expansion to the elastic deformation of the entire aquifer system is determined by subtracting the estimated aquifer contribution from the total observed deformation. The total specific storage and storage coefficient values for the aquitards incorporate a pore-water compressibility component based on a porosity of 0.4 . This value is representative of porosities measured by Johnson and others (1968) for a large number of cores from aquitards in the San Joaquin Valley.

Although the depths, thicknesses, lithology, and stratigraphy of the compacting sediments vary substantially among the seven monitoring sites in the San Joaquin Valley, the values of aquitard specific storage are remarkably similar. The elastic values $\left(S_{s}^{\prime}\right)$ range from $2.4 \times 10^{-6} \mathrm{ft}^{-1}$ to $7.3 \times 10^{-6} \mathrm{ft}^{-1}$ and average $4.7 \times 10^{-6} \mathrm{ft}^{-1}$. These values differ somewhat from Helm's model values for skeletal specific storage $\left(S^{h}{ }_{\text {ske }}\right)$ because of inclusion of pore-water compressibility and exclusion of aquifer compressibility. The inelastic values $\left(S_{s k v}^{\prime}\right)$ derived from Helm's aquitard model range from $1.4 \times 10^{-4} \mathrm{ft}^{-1}$ to $6.7 \times 10^{-4} \mathrm{ft}^{-1}$ and average $3.3 \times 10^{-4} \mathrm{ft}^{-1}$. For the aquifer system as a whole the tabulated values of elastic specific storage $\left(S_{s}^{*}\right)$ are even more consistent, ranging only between $1.9 \times 10^{-6} \mathrm{ft}^{-1}$ and $3.9 \times 10^{-6} \mathrm{ft}^{-1}$. These values for the entire aquifer system have limited physical significance because they combine the compressibilities and thicknesses of aquifer and aquitard materials at each site. They are, however, statistically significant in that they suggest that storage coefficients for the confined aquifer system and for stress changes in the elastic range may be approximated with some confidence simply from a knowledge of aquifer-system thickness.

The tabulated storage properties of the aquifers and aquitards in the compacting aquifer systems are significant in two related but somewhat different ways. The component of specific storage and storage coefficient attributable to compressibility of the granular skeleton of the sediments determines the magnitude of mechanical deformation resulting from a unit change in head (pore pressure). Thus, these parameters $\left(S_{s k e}, S_{s k e}^{\prime}, S_{k e}, S_{k e}^{\prime}\right.$, $S_{s k v}^{\prime}$, and $S_{k v}^{\prime}$ ) permit prediction of the ultimate compaction or expansion that would be caused by a given decline or recovery of water levels. The total storage parameters 
of aquifer-system compaction

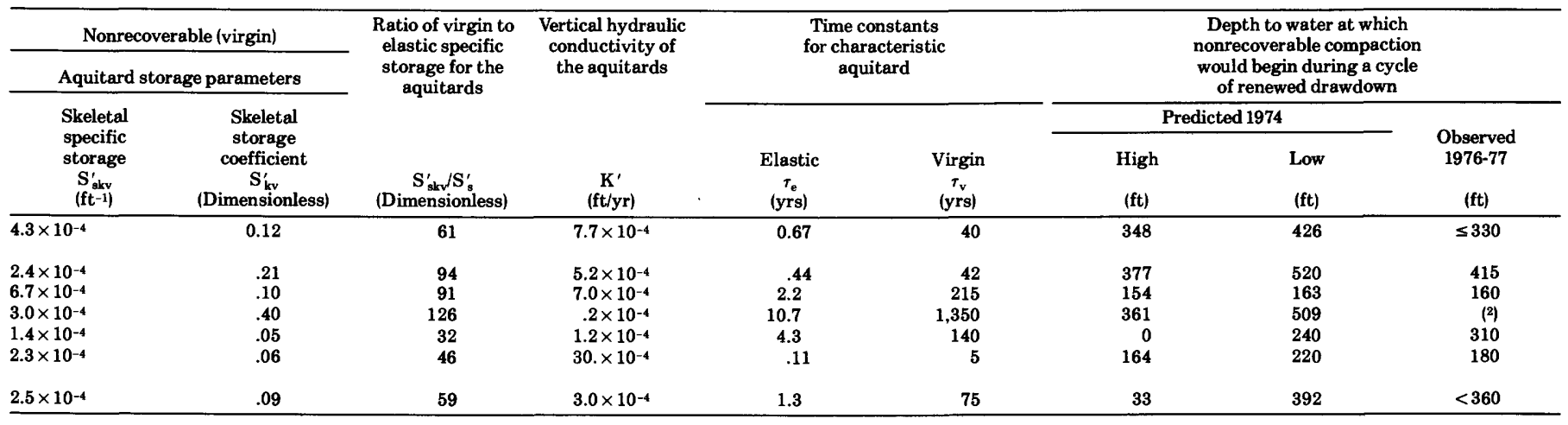

that incorporate not only the skeletal compressibility but also the pore water compressibility $\left(S_{s}, S_{s}^{\prime}, S, S^{\prime}\right)$ permit calculation of the volumes of water that are released from or taken into storage within the confined aquifer system for a given decline or recovery of water levels.

When the increasing intergranular stress caused by declining pore pressures exceeds the maximum past stress at any point in the aquifer system, the nonrecoverable, or virgin, storage parameters $\left(S_{s k v}, S_{k v}^{\prime}\right)$ become operative. Under these circumstances the skeletal component of the aquitard storage parameters increases materially, typically by factors of 50 to 100 . With such large skeletal compressibility the contribution of pore water compressibility to the total aquitard storage parameters is relatively insignificant. Thus, when stresses are in the virgin range, the total aquitard storage parameters $\left(S_{s v}^{\prime}\right.$ and $S^{\prime}{ }_{v}$ do not differ measurably from the skeletal storage parameters and therefore are not tabulated. The possible role of increased aquifer compressibility at stresses greater than maximum past stress is not known but is thought to be minor in comparison with the increased compressibility of the aquitards. Therefore, the virgin aquitard storage coefficient may be taken as virtually equivalent to the total aquifer-system storage coefficient within the limits of accuracy of the modeling procedure.

It must be emphasized that the thickness and volume changes calculated from the aquitard storage parameters are ultimate values; these values are attained only when pore pressures within the aquitards have adjusted to equilibrium with those in the adjacent aquifers. When aquifer heads are drawn down, the attainment of such equilibrium depends upon the expulsion of stored water from the interior regions of the aquitards to the adjacent aquifers. This flow, which allows the aquitards to compact, is impeded by the very low permeability characteristic of the aquitards and by the length of the flow line along which such flow must occur. Additionally, the required volume of flow is governed by the unit storativity (specific storage) of the aquitard and by its thickness. In combination these factors determine the time required for pore pressures throughout an aquitard to approach equilibrium with those in the adjacent aquifers. Thus an aquitard time constant, $\tau$, is defined as $\tau=\frac{S_{s}^{\prime}\left(b^{\prime} / 2\right)^{2}}{K^{\prime}}$ The constant represents the time required to produce about 90 percent of the compaction (or expansion) that would ultimately result from a given stepwise increment of water-level drawdown (or recovery). $\mathrm{Be}$ cause aquitard thickness (half thickness in the typical case of an aquitard bounded both above and below by aquifers) enters into the time constant in the second power, it has a strong influence on the magnitude of this parameter.

The wide range of thicknesses and permeabilities to be found among the aquitards at a given site suggest that time constants for the individual aquitards will range through several orders of magnitude. Nevertheless it is useful for comparative purposes to calculate time constants based on the weighted average thickness and permeability of the "characteristic" aquitard at each monitoring site. The tabulated values show that representative time constants associated with drawdowns in the range of virgin stresses may be very long, typically several decades to several centuries. Time constants associated with water-level recovery and with fluctuations in the elastic range of stress are relatively short because of the much smaller value of specific storage.

If the duration of a given sustained stress (aquifer drawdown) is substantially less than the calculated time constant, it may be anticipated that pore pressures within the medial regions of the thicker aquitards will be appreciably higher than those in the bounding aquifers. Under these circumstances there is the potential for significant amounts of residual nonrecoverable compaction that would ultimately occur if that stress were sustained indefinitely.

The tabulated values of elastic time constants suggest that at many locations in the San Joaquin Valley a 
typical pumping season of 6 months duration is long enough to permit a substantial fraction of the ultimate elastic aquitard storage ( $\mathbf{S}^{\prime}$ ) to appear as flow in the aquifers. However, if seasonal drawdowns create stresses in the aquitards greater than the maximum past stress, the progress of transient compaction will then be in accordance with the virgin time constants. Under these circumstances only a small fraction of the ultimate water of compaction will be yielded to wells in the course of a single pumping season. Many decades or centuries of repeated seasonal drawdown and recovery through the same range might be required to extract most of the ultimate nonrecoverable compaction calculated to result from the maximum drawdown occurring each season.

In his aquitard drainage model, Helm (1977) calculates the time-varying distribution of pore pressures within a "characteristic" aquitard of weighted average thickness in response to a known or projected history of head change in the adjacent aquifers. As indicated by the time constants, the pore-pressure changes in the aquitards will always lag behind those in the aquifers; with pore-pressure declines in the virgin range the lag may be very great. By calculating the excess pore pressure in the medial regions of a characteristic aquitard during aquifer drawdown, the model indicates the magnitude of aquifer recovery that would be required to reverse the hydraulic gradients in the aquitard and to stop compaction. By "remembering" the minimum pore pressures (maximum stresses) attained within the aquitard throughout the history of aquifer depletion, the model determines whether flow and deformation processes at any given time are governed by elastic or virgin storage parameters. Thus the model can compute the points on an aquifer hydrograph at which nonrecoverable compaction of a characteristic aquitard would cease during recovery and resume during a subsequent drawdown cycle. For an aquitard having a longer time constant that is a thicker or less permeable stratum, such points would occur at lesser depths to water than for a characteristic aquitard.

Using the procedure just outlined, Helm (1978, table 2) estimated for each site a range of the "critical" depths to water at which subsidence would resume in the event of renewed drawdowns from the recovered water levels of the early 1970's. The estimates were based on water-level records available through 1974 and the modeled distribution of residual excess pore pressures at that time. The high (shallow-water level) end of the range was based on the calculated maximum past stresses in the middle of the thickest aquitard. The low end of the range was based on calculated maximum past stresses in the middle of the characteristic aquitard. Helm's estimates are incorporated in table 4 of this report, along with the depths to water at which renewed nonrecoverable compaction was observed during the 1976-77 period of increased pumping. In general, the model was reasonably successful in predicting a range of water levels associated with the resumption of perceptible subsidence.

\section{COMPUTER PLOTS OF FIELD RECORDS}

The records of compaction and of depth to water in the extensometer wells or in nearby observation wells have been computerized on a daily basis, and computer plots of these records through 1979 are included as figures 41 through 66 at the end of this report. Plots of subsidence of a surface bench mark located at the measuring site, determined by periodic precise leveling to a stable bench mark, are also included for all or part of the period of compaction measurement. Table 5 supplies pertinent information about the individual wells (figs. 41-66). Site locations are shown on figure 40.

With respect to the objectives of the cooperative study of land subsidence, the primary purpose of including these records is to show graphically the measured compaction and subsidence at specific sites, and, so far as possible, the change in effective stress in the pertinent aquifers at these sites, as indicated by the hydrographs. Because of the confining beds and multiple-aquiferaquitard systems, it is difficult to obtain water-level measurements that specifically represent the mean stress change for the interval in which compaction is being measured.

Change in applied stress and stress-compaction or stress-strain relationships are plotted for 16 of the 26 figures. In these figures, compaction equals the change in thickness of the compacting interval, and strain refers to the compaction divided by the thickness of the compacting interval. Of the 16 relationships included, 7 are in the Los Banos-Kettleman City area, 7 are in the TulareWasco area, and 2 are in the Arvin-Maricopa area. Change in applied stress was plotted for each site where the measurements of depth to water were considered to define, at least approximately, the change in applied stress on the aquifer-system thickness interval being measured by the extensometer.

At sites where both the water table and the artesian head were measured, as at 16/15-34N (fig. 49) and 23/25$16 \mathrm{~N}$ (figs. 58 and 59), the change in applied stress within a confined aquifer system, due to changes in both the water table and the artesian head, may be summarized concisely (Poland and others, 1972, p. 6) as 
TABLE 5.-Information on wells or sites for which records are included in figures 41-67

[See figure $\mathbf{4 0}$ for location of well or site]

\begin{tabular}{|c|c|c|c|c|c|c|c|c|c|}
\hline $\begin{array}{l}\text { Fig. } \\
\text { No. }\end{array}$ & $\begin{array}{l}\text { Well or } \\
\text { site No. }\end{array}$ & $\begin{array}{c}\text { Type } \\
\text { of } \\
\text { exten- } \\
\text { someter }\end{array}$ & $\begin{array}{c}\text { Water-level } \\
\text { recorder or } \\
\text { obervation } \\
\text { well }\end{array}$ & $\begin{array}{l}\text { Depth } \\
\text { of } \\
\text { well } \\
\text { (ft) }\end{array}$ & $\begin{array}{l}\text { Perforated } \\
\text { interval } \\
\text { (ft) }\end{array}$ & $\begin{array}{c}\text { Number } \\
\text { of } \\
\text { compac- } \\
\text { tion } \\
\text { plots }\end{array}$ & $\begin{array}{l}\text { Number } \\
\text { of } \\
\text { hydro- } \\
\text { graphs }\end{array}$ & $\begin{array}{l}\text { Stress-compaction } \\
\text { or stress-strain } \\
\text { plot made }\end{array}$ & Remarks \\
\hline \multicolumn{10}{|c|}{ Los Banos-Kettleman City Area } \\
\hline \multirow[t]{5}{*}{41} & $12 / 12-16 \mathrm{H} 2$ & Cable & $\ldots \ldots \ldots \ldots$ & 1,000 & $\ldots \ldots \ldots \ldots$ & & $\ldots \ldots$ & …........... & $\begin{array}{l}\text { Compaction measured } \\
\text { to } 1,000 \mathrm{ft} \text {. }\end{array}$ \\
\hline & $16 \mathrm{H} 3$ & Cable & (n........... & 350 & & 6 & & n............... & $\begin{array}{l}\text { Compaction measured } \\
\text { to } 350 \mathrm{ft} \text {. }\end{array}$ \\
\hline & $16 \mathrm{H} 4$ & Cable & ................. & 500 & $\ldots$ & & & . $\ldots \ldots \ldots \ldots . . .6$ & $\begin{array}{l}\text { Compaction measured } \\
\text { to } 500 \mathrm{ft} \text { (abandoned } \\
1976 \text { ). }\end{array}$ \\
\hline & $16 \mathrm{H} 5$ & ......... & Obs. & 720 & $670-712$ & ......... & 1 & ................. & $\begin{array}{l}\text { Complex head } \\
\text { relations, lower zone }\end{array}$ \\
\hline & $16 \mathrm{H} 6$ & $\ldots$ & Obs. & 926 & $770-909$ & .......... & 1 & ….... & $\begin{array}{l}\text { Complex head } \\
\text { relations, lower zone }\end{array}$ \\
\hline 42 & $13 / 12-20 \mathrm{D} 1$ & Cable & Rec. & 681 & $425-665$ & 1 & 1 & ................. & $\begin{array}{l}\text { Primarily observation } \\
\text { well, lower zone, } \\
\text { compaction } \\
\text { measurement } \\
\text { includes only part of } \\
\text { lower zone } \\
\text { (abandoned 1974). }\end{array}$ \\
\hline 43 & 13/15-35D5 & Pipe & Rec. & 440 & $373-433$ & 1 & 1 & 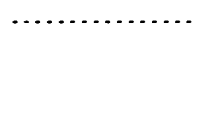 & $\begin{array}{l}\text { Compaction, upper } \\
\text { zone; hydrograph } \\
\text { not representative } \\
\text { for all stress-change } \\
\text { interval. }\end{array}$ \\
\hline 44 & $14 / 12-12 \mathrm{H} 1$ & Cable & Rec. & 913 & $740-936$ & 1 & 1 & & $\begin{array}{l}\text { Primarily observation } \\
\text { well, lower zone; } \\
\text { compaction } \\
\text { measurement } \\
\text { includes only part of } \\
\text { lower zone. }\end{array}$ \\
\hline \multirow[t]{3}{*}{45} & 14/13-11D3 & ......... & Rec. & 240 & $180-240$ & ......... & 1 & n................... & $\begin{array}{l}\text { Water-table well } \\
\text { (abandoned 1974). }\end{array}$ \\
\hline & 11D4 & Cable & Obs. & 780 & . & 3 & $\ldots .$. & n............... & $\begin{array}{l}\text { Compaction measured } \\
\text { to } 780 \mathrm{ft} \text { (abandoned } \\
\text { 1974). }\end{array}$ \\
\hline & $11 \mathrm{D} 6$ & Cable & Rec. & 1,358 & $1,133-1,196$ & & 1 & Stress-strain & $\begin{array}{l}\text { Compaction measured } \\
\text { to } 1,358 \mathrm{ft} \text {, lower } \\
\text { zone observation } \\
\text { well. }\end{array}$ \\
\hline 46 & 15/13-11D2 & Cable & Rec. & 960 & $900-960$ & 1 & 1 & 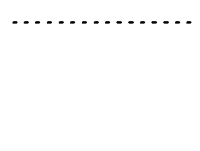 & $\begin{array}{l}\text { Primarily observation } \\
\text { well, lower zone; } \\
\text { compaction } \\
\text { measurement } \\
\text { includes only part of } \\
\text { lower zone. }\end{array}$ \\
\hline 47 & $15 / 14-14 \mathrm{~J} 1$ & ........ & Rec. & 1,010 & Unknown & …... & 1 & 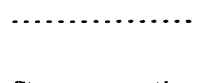 & $\begin{array}{l}\text { Representative for } \\
\text { lower zone } \\
\text { (abandoned 1977). }\end{array}$ \\
\hline 48 & $15 / 16-31$ N3 & Cable & Rec. & 596 & $497-537$ & 1 & 1 & Stress-compaction & $\begin{array}{l}\text { Compaction and } \\
\text { hydrograph, upper } \\
\text { zone. }\end{array}$ \\
\hline \multirow[t]{4}{*}{49} & $16 / 15-34 \mathrm{~N} 1$ & Cable & ............ & 2,000 & - $\cdots \cdots$ & & $\cdots$ & Stress-strain & $\begin{array}{l}\text { Compaction measured } \\
\text { to } 2,000 \mathrm{ft} \text {. }\end{array}$ \\
\hline & $34 \mathrm{~N} 2$ & Cable & ............ & 703 & & 6 & & . & $\begin{array}{l}\text { Compaction measured } \\
\text { to } 703 \mathrm{ft} \text {. }\end{array}$ \\
\hline & $34 \mathrm{~N} 3$ & Cable & ............ & 503 & & & & n................. & $\begin{array}{l}\text { Compaction measured } \\
\text { to } 503 \mathrm{ft} \text {. }\end{array}$ \\
\hline & $34 \mathrm{~N} 4$ & ........ & Rec. & 1,130 & $1,052-1,112$ & ........ & 1 & $\ldots \ldots \ldots \ldots$ & $\begin{array}{l}\text { Observation well, } \\
\text { lower zone. }\end{array}$ \\
\hline & $34 \mathrm{~N} 5$ & & Obs. & 300 & $240-300$ & & 1 & $\ldots \ldots \ldots \ldots$ & Water-table well. \\
\hline 50 & $17 / 15-14 Q 1$ & Cable & Rec. & 2,315 & $1,064-1,094$ & 1 & 1 & $\ldots \ldots \ldots \ldots$ & $\begin{array}{l}\text { Measures casing } \\
\text { deformation to 2,315 } \\
\text { ft, lower zone water } \\
\text { level. }\end{array}$ \\
\hline 51 & 18/16-33A 1 & Cable & Obs. & 1,070 & $858-1,070$ & 1 & 1 & ……...... & $\begin{array}{l}\text { Primarily observation } \\
\text { well, lower zone; } \\
\text { compaction } \\
\text { measurement } \\
\text { includes only part of } \\
\text { lower zone. }\end{array}$ \\
\hline \multirow[t]{3}{*}{52} & $18 / 19-20 \mathrm{P} 1$ & ......... & Rec. & 695 & $647-687$ & ...... & 1 & ............... & $\begin{array}{l}\text { Lower zone } \\
\text { observation well. }\end{array}$ \\
\hline & $20 \mathrm{P} 2$ & Cable & Rec. & 578 & $497-537$ & 1 & 1 & Stress-strain & $\begin{array}{l}\text { Compaction and water } \\
\text { level, upper zone. }\end{array}$ \\
\hline & 20P3 & -....... & Rec. & 222 & $200-222$ & $\ldots \ldots \ldots$ & 1 & n.......... & $\begin{array}{l}\text { Upper zone } \\
\text { observation well. }\end{array}$ \\
\hline
\end{tabular}


TABLE 5.-Information on wells or sites for which records are included in figures 41-67-Continued

\begin{tabular}{|c|c|c|c|c|c|c|c|c|c|}
\hline $\begin{array}{l}\text { Fig. } \\
\text { No. }\end{array}$ & $\begin{array}{l}\text { Well or } \\
\text { site No. }\end{array}$ & $\begin{array}{l}\text { Type } \\
\text { of } \\
\text { exten- } \\
\text { someter }\end{array}$ & $\begin{array}{c}\text { Water-level } \\
\text { recorder or } \\
\text { obervation } \\
\text { well }\end{array}$ & $\begin{array}{l}\text { Depth } \\
\text { of } \\
\text { well } \\
\text { (ft) }\end{array}$ & $\begin{array}{l}\text { Perforated } \\
\text { interval } \\
\text { (ft) }\end{array}$ & $\begin{array}{l}\text { Number } \\
\text { of } \\
\text { compac- } \\
\text { tion } \\
\text { plots } \\
\end{array}$ & $\begin{array}{l}\text { Number } \\
\text { of } \\
\text { hydro- } \\
\text { graphs }\end{array}$ & $\begin{array}{l}\text { Stress-compaction } \\
\text { or stress-strain } \\
\text { plot made }\end{array}$ & Remarks \\
\hline \multicolumn{10}{|c|}{ Los Banos-Kettleman City Area - Continued } \\
\hline$\overline{53}$ & 19/16-23P2 & Cable & Rec. & 2,200 & Unknown & 1 & 1 & Stress-compaction & $\begin{array}{l}\text { Measures casing } \\
\text { deformation to 2,200 } \\
\text { ft, lower zone water } \\
\text { level (abandoned } \\
\text { 1974). }\end{array}$ \\
\hline 54 & 20/18-6D1 & Cable & Rec. & 1,007 & $\begin{array}{l}760-835 \\
851-872\end{array}$ & 1 & 1 & $\ldots \ldots \ldots$ & $\begin{array}{l}\text { Primarily observation } \\
\text { well lower zone, } \\
\text { compaction } \\
\text { measurement to } 867 \\
\text { ft (includes only part } \\
\text { of lower zone). }\end{array}$ \\
\hline 55 & 20/18-11Q1 & Cable & Obs. & 710 & $650-710$ & 1 & 1 & Stress-compaction & $\begin{array}{l}\text { Compaction and water } \\
\text { level. }\end{array}$ \\
\hline \multirow[t]{2}{*}{56} & 11Q2 & Pipe & $\ldots \ldots \ldots$ & 845 & (n......... & \multirow{2}{*}{3} & & (n........... & $\begin{array}{l}\text { Compaction measured } \\
\text { to } 845 \mathrm{ft} \text {. }\end{array}$ \\
\hline & $11 Q 3$ & Cable & Obs. & 1,930 & $1.885-1,925$ & & 1 & Stress-strain & $\begin{array}{l}\text { Measures casing } \\
\text { deformation to } 1,930 \\
\text { ft, lower zone water } \\
\text { level. }\end{array}$ \\
\hline \multicolumn{10}{|c|}{ Tulare-Wasco Area } \\
\hline 57 & 22/27-30D2 & Pipe & Rec. & 1,246 & $1,083-1,207$ & 1 & 1 & Stress-compaction & $\begin{array}{l}\text { Compaction measured } \\
\text { to } 1,246 \mathrm{ft} \text {. }\end{array}$ \\
\hline \multirow[t]{2}{*}{58} & $23 / 25-16 \mathrm{~N} 1$ & Cable & Rec. & 760 & None & \multirow[t]{2}{*}{3} & & Stress-strain & $\begin{array}{l}\text { Compaction measured } \\
\text { to } 760 \mathrm{ft} \text {. }\end{array}$ \\
\hline & $16 \mathrm{~N} 3$ & Cable & Rec. & 430 & $360-420$ & & 1 & 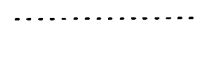 & $\begin{array}{l}\text { Compaction measured } \\
\text { to } 430 \mathrm{ft} \text {, lower zone } \\
\text { water level. }\end{array}$ \\
\hline \multirow[t]{2}{*}{59} & $23 / 25-16 \mathrm{~N} 3$ & Cable & Rec. & 430 & $360-420$ & \multirow[t]{2}{*}{3} & 1 & Stress-strain & $\begin{array}{l}\text { Compaction measured } \\
\text { to } 430 \mathrm{ft} \text {, lower zone } \\
\text { water level. }\end{array}$ \\
\hline & $16 \mathrm{~N} 4$ & Cable & Rec. & 250 & $200-240$ & & 1 & (n.................. & $\begin{array}{l}\text { Compaction measured } \\
\text { to } 250 \mathrm{ft} \text {, upper zone } \\
\text { water level. }\end{array}$ \\
\hline 60 & $24 / 26-34 \mathrm{~F} 1$ & Cable & Rec. & 1,522 & $400-1,522$ & 1 & 1 & Stress-compaction & $\begin{array}{l}\text { Compaction measured } \\
\text { to } 1,510 \mathrm{ft} \text {. }\end{array}$ \\
\hline 61 & $24 / 26-36 \mathrm{~A} 2$ & Cable & ........... & 2,200 & ........... & 1 & ......... & Stress-compaction & $\begin{array}{l}\text { Compaction measured } \\
\text { to } 2,200 \mathrm{ft} \text {, assumed } \\
\text { that hydrograph for } \\
\text { 1A2 represents } \\
\text { change in } \\
\text { compacting zone of } \\
36 \mathrm{~A} 2 \text {. }\end{array}$ \\
\hline 62 & 25/26-1A2 & Cable & Rec. & 875 & $200-600$ & 1 & 1 & Stress-compaction & $\begin{array}{l}\text { Compaction measured } \\
\text { to } 892 \mathrm{ft} \text { (abandoned } \\
1978 \text { ). }\end{array}$ \\
\hline \multirow[t]{2}{*}{63} & $26 / 23-16 \mathrm{H} 2$ & Pipe & Rec. & 1,002 & $938-978$ & 1 & 1 & Stress-compaction & $\begin{array}{l}\text { Compaction measured } \\
\text { to } 1,002 \mathrm{ft} \text {, lower } \\
\text { zone water level. }\end{array}$ \\
\hline & $16 \mathrm{H} 3$ & Pipe & Rec. & 355 & 315-335 & 1 & 1 & 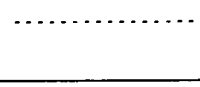 & $\begin{array}{c}\text { Compaction measured } \\
\text { to } 355 \mathrm{ft} \text {, lower zone } \\
\text { water level. } \\
\end{array}$ \\
\hline \multicolumn{10}{|c|}{ Arvin-Maricopa } \\
\hline 64 & $32 / 28-20 Q 1$ & Cable & Rec. & 970 & Unknown & 1 & 1 & Stress-compaction & $\begin{array}{l}\text { Compaction measured } \\
\text { to } 970 \mathrm{ft} \text { (abandoned } \\
1978 \text { ). }\end{array}$ \\
\hline 65 & $12 \mathrm{~N} / 21 \mathrm{~W}-34 \mathrm{Q} 1$ & Cable & Rec. & 810 & $400-800$ & 1 & 1 & 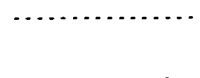 & $\begin{array}{l}\text { Compaction measured } \\
\text { to } 810 \mathrm{ft} \text { (abandoned } \\
\text { 1974). }\end{array}$ \\
\hline 66 & $11 \mathrm{~N} / 21 \mathrm{~W}-3 \mathrm{~B} 1$ & Cable & Rec. & 1,480 & $1,037-1,237$ & 1 & 1 & Stress-compaction & $\begin{array}{l}\text { Compaction measured } \\
\text { to } 1,480 \mathrm{ft} \text {, water } \\
\text { level representative } \\
\text { of lower zone. }\end{array}$ \\
\hline
\end{tabular}

$$
\Delta P_{a}=-\left(\Delta h_{c}-\Delta h_{u} Y_{s}\right)
$$

where

$P_{a}$ is the applied stress expressed in feet of water, $h_{c}$ is the head (assumed uniform) in the confined aquifer system,

$h_{u}$ is the head in the overlying unconfined aquifer, and
$Y$ is the average specific yield (expressed as a decimal fraction) in the interval of water-table fluctuation.

At sites where changes in the water table were not known or were assumed to be zero, the plot of change in applied stress is identical in direction and magnitude to the change in artesian head (plotted as depth to water) be- 
cause (1) both are expressed in feet of water, and (2) the change in stress in the confined system is solely a change in seepage stress, with magnitude equal to the change in vertical distance between the water table and the artesian head.

Stress-compaction plots are included for seven wells in which the measured water-level change is considered to be representative for the compacting zone being measured but where the thickness of the compacting zone is not known. For example, in well 15/16-31N3 (fig. 48), the extensometer measures change in thickness between the land surface and the anchor at a depth of $596 \mathrm{ft}$. Inspection of the electric log (not shown) suggests that the deposits to a depth of $320 \mathrm{ft}$ below land surface probably are not being affected by as much change in stress as is indicated by the hydrograph and may not be affected by any change in stress. The hydrograph does represent change in applied stress in the depth interval 320-596 ft, and the compacting interval is at least $276 \mathrm{ft}$ thick.

Stress-strain plots are included for six wells in which the measured water-level change is considered to represent change in applied stress throughout the compacting zone being measured, and where the thickness of the compacting zone is known. For example, at site 23/25$16 \mathrm{~N}$ (fig. 58), the extensometers in wells N3 and N1 measure change in thickness between the land surface and the anchors at depths of 430 and $760 \mathrm{ft}$, respectively. The deposits between depths of 430 and $760 \mathrm{ft}$, which are $330 \mathrm{ft}$ thick, are affected by the stress change defined by the hydrographs for wells N3 and N4. Therefore, on the stress-strain plot for this site and depth interval (fig. 58), the strain has been computed as measured compaction divided by $330 \mathrm{ft}$ of thickness.

The rising artesian head in the aquifers of the lower zone in the Los Banos-Kettleman City area has nearly eliminated the pore-pressure differential between aquifers and aquitards, hence the graphs showing a large rise in head from 1968 through 1979 also show a very marked decrease in rate of compaction.

Extensometer site 26/23-16H, northwest of Wasco (fig. 63), was added to the subsidence monitoring program in 1978. These wells were drilled by the Los Angeles Department of Water and Power in 1974 at their proposed nuclear power site, which has since been abandoned, 10 mi west of Wasco. Well $16 \mathrm{H} 2$ is an extensometer well $1,002 \mathrm{ft}$ deep, perforated from 938 to $978 \mathrm{ft}$. Well $16 \mathrm{H} 3$ is an extensometer well $355 \mathrm{ft}$ deep, perforated from 315 to $335 \mathrm{ft}$. They were completed at these depths to supply water-level data for the upper and lower part of the lower water-bearing zone. However, water levels in both wells are nearly the same. Both extensometers have recorded a net expansion of the aquifer system of a few hundredths of a foot since August 1978. This net expansion is due to the gross seasonal compaction and expansion and time of installation. Well $16 \mathrm{H} 2$ recorded $0.040 \mathrm{ft}$ of apparently nonrecoverable compaction superimposed on $0.097 \mathrm{ft}$ of elastic compression and expansion and $16 \mathrm{H} 3$ recorded $0.002 \mathrm{ft}$ of apparently nonrecoverable compaction superimposed on $0.030 \mathrm{ft}$ of elastic compression and expansion during the 1979 drawdown and recovery.

\section{COMPACTION-SUBSIDENCE RATIOS}

Table 6 shows the amounts of measured compaction and measured subsidence (elevation change) at extensometer sites where leveling data are available. The ratio of measured compaction to measured subsidence, expressed as a percentage, was computed for the period of record available. Percentages are sometimes erratic for short periods of control at some sites; some periods of measured compaction and leveling are combined to make the compaction/subsidence ratio more consistent, and some are not shown owing to incomplete data or mechanical problems at the extensometer site.

At extensometer site 12/12-16H2 (1,000-ft depth), the bench-mark elevation was surveyed five times during the period in which compaction was being measured. The average compaction/subsidence ratio for the period of record was 62 percent, with a low of 54 percent from March 1963 to February 1966 and a high of 71 percent from November 1959 to March 1963.

Some sites listed in this table are upper-zone wells, such as 13/15-35D5 (table 5); the measurements represent only a small percentage of the overall subsidence. Other wells, such as 14/12-12H1, which were drilled mainly for water-level data, are deep enough to measure only part of the compaction of the lower zone.

At extensometer site 16/15-34N1, Cantua Creek, the compaction/subsidence ratio was 88 percent from February 1960 to January 1978. This site is located along the California Aqueduct in one of the maximum subsidence areas of the valley. When this well was drilled in 1958, most irrigation wells in this immediate area were completed at about the 2,000-ft depth. In the 1960's, nearby irrigation wells were drilled to depths as great as $2,700 \mathrm{ft}$, causing compaction in the interval below the 2,000 -ft extensometer well. The compaction/subsidence ratio from February 1975 to January 1978 was 72 percent, the lowest of record. The ratio from January 1972 to February 1975 was 97 percent, the highest of record. Owing to the adjustment of the 1975 leveling, this ratio suggests that the adjusted elevation of bench mark G1046 in 1975 may have been too high. The small subsidence and compaction values are greatly affected by a small change in either value. For example, if the adjusted 1975 elevation of 
TABLE 6.-Ratio of compaction to subsidence for periods of leveling in the Los Banos-Kettleman City, Tulare-Wasco, and Arvin-Maricopa areas

[Ratio of compaction/subsidence: Value shown on total line is ratio for period of record]

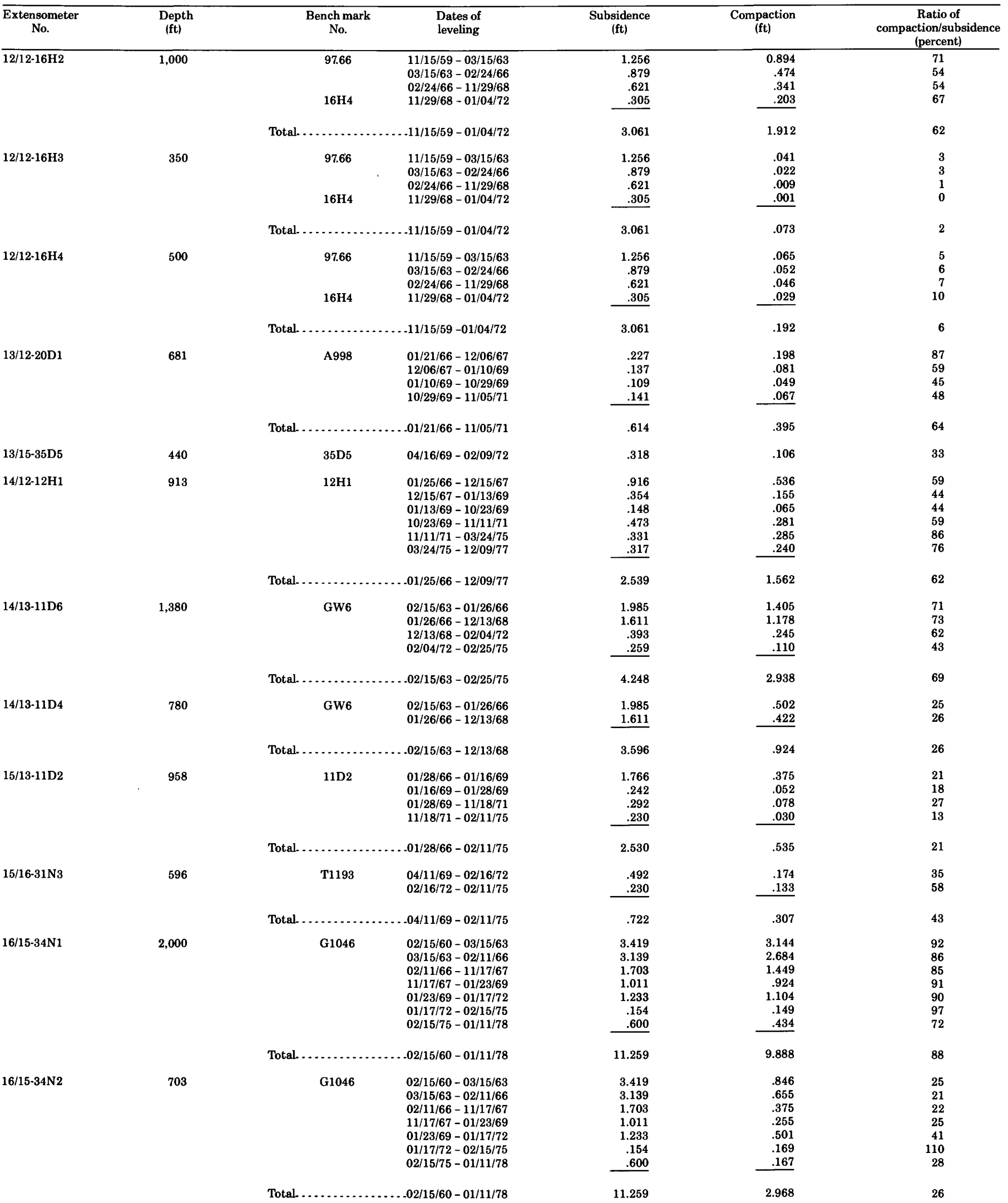


TABLE 6.-Ratio of compaction to subsidence for periods of leveling in the Los Banos-Kettleman City, Tulare-Wasco, and Arvin-Maricopa areas-Continued

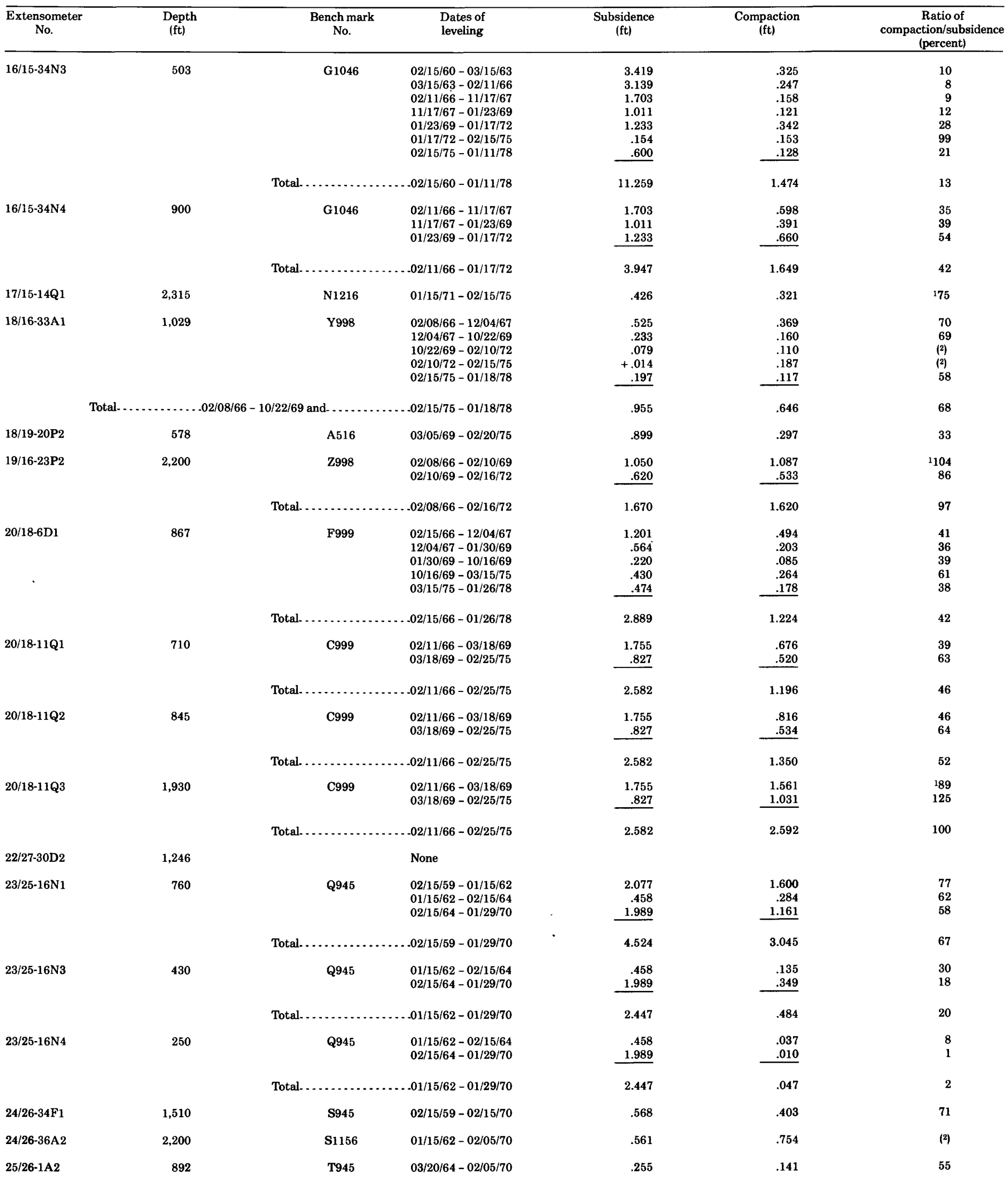


TABLE 6.-Ratio of compaction to subsidence for periods of leveling in the Los Banos-Kettleman City, Tulare-Wasco, and Arvin-Maricopa areas-Continued

\begin{tabular}{|c|c|c|c|c|c|c|}
\hline $\begin{array}{c}\text { Extensometer } \\
\text { No. }\end{array}$ & $\begin{array}{l}\text { Depth } \\
\text { (ft) }\end{array}$ & $\begin{array}{l}\text { Bench mark } \\
\text { No. }\end{array}$ & $\begin{array}{l}\text { Dates of } \\
\text { leveling }\end{array}$ & $\begin{array}{c}\text { Subsidence } \\
\text { (ft) }\end{array}$ & $\begin{array}{c}\text { Compaction } \\
\text { (ft) }\end{array}$ & $\begin{array}{c}\text { Ratio of } \\
\text { compaction/subsidence } \\
\text { (percent) }\end{array}$ \\
\hline 26/23-16H2 & 1,002 & & None & & & \\
\hline $32 / 28-20 Q 1$ & 970 & L365 & $02 / 15 / 65-03 / 06 / 70$ & 1.591 & .914 & 57 \\
\hline \multirow[t]{2}{*}{$12 N / 21 W-34 Q 1$} & 810 & W1156 & $\begin{array}{l}01 / 01 / 62-02 / 15 / 65 \\
02 / 15 / 65-03 / 09 / 70\end{array}$ & $\begin{array}{l}1.398 \\
1.870 \\
\end{array}$ & $\begin{array}{l}.716 \\
.771 \\
\end{array}$ & $\begin{array}{l}51 \\
41\end{array}$ \\
\hline & & …....... & $.01 / 01 / 62-03 / 09 / 70$ & 3.268 & 1.487 & 46 \\
\hline \multirow[t]{2}{*}{$11 N / 21 W-3 B 1$} & 1,480 & M991 & $\begin{array}{l}02 / 15 / 65-03 / 09 / 70 \\
03 / 09 / 70-05 / 03 / 75 \\
05 / 03 / 75-03 / 17 / 78\end{array}$ & $\begin{array}{r}2.047 \\
.614 \\
.613\end{array}$ & $\begin{array}{r}1.836 \\
.572 \\
.448 \\
\end{array}$ & $\begin{array}{l}90 \\
93 \\
73\end{array}$ \\
\hline & & $\ldots \ldots \ldots \ldots$ & $.02 / 15 / 65-03 / 17 / 78$ & 3.274 & 2.836 & 87 \\
\hline
\end{tabular}

1Approximate compaction; extensometer measures casing deformation.
2Not computed because of mechanical and (or) data problems at the site.

bench mark G1046 had been only $0.015 \mathrm{ft}$ lower (subsidence 1972-75 of 0.169 ft), the 1972-75 ratio would have been 88 percent. The same error, however, would have increased the $1975-78$ ratio to only 74 percent.

At extensometer site 18/16-33A1, the compaction/ subsidence ratio was 70 percent from February 1966 to December 1967 and 69 percent from December 1967 to October 1969. From 1969 to 1972 and 1972 to 1975 , measured compaction was larger than subsidence. No compaction/subsidence ratios are shown in table 6 for these periods. No maintenance or data problems (except the 1975 leveling adjustment) occurred at this site and the bench mark was not disturbed. The compaction/subsidence difference may be related to change below the extensometer depth of $1,029 \mathrm{ft}$ (rebound of the aquifer system below $1,029 \mathrm{ft}$ with continuing compaction above $1,029 \mathrm{ft}$ ). The extensometer measured 58 percent of the subsidence from February 1975 to January 1978 and 68 percent from 1966 to 1978.

Extensometer site 19/16-23P2, near an active irrigation well during the time of record, shows a compaction/ subsidence ratio of 97 percent from February 1966 to February 1972. Well 19/16-23P2 was drilled as an oil test, cased, cemented, and plugged back to $2,200 \mathrm{ft}$ before being converted to an irrigation well. The well was abandoned owing to low production and the Geological Survey converted the well to an extensometer and waterlevel site. Because of the well construction, the extensometer measures casing deformation due to aquifer compaction.

Extensometer site 20/18-11Q3 is also an abandoned oil test well, cased, cemented, and plugged back to 1,930 $\mathrm{ft}$. The Geological Survey converted this well to an exten;someter and water-level observation site in 1962 (Poland and Ireland, 1965). This well also measures casing deformation due to aquifer compaction. The compaction/subsidence ratio was 89 percent from February 1966 to March 1969. Mechanical problems occurred at this site during the winter of $1965-66$ and the summer of 1971 . The 1965-66 compaction data were not adjusted nor included in table 6, but owing to the large unexplained change in 1971, the 1971 compaction data were adjusted. The compaction/subsidence ratio was roughly 100 percent from 1966 to 1975.

At the Pixley extensometer site 23/25-16N1, the compaction/subsidence ratio was 77 percent from February 1959 to January 1962, 62 percent from January 1962 to February 1964, and 58 percent from February 1964 to January 1970 . The decreasing compaction/subsidence ratio is directly related to the amount of ground water pumped. As shown in figure 29, small annual water-level fluctuation causes small amounts of compaction and, presumably, comparable amounts of subsidence. For the 11 years from February 1959 to January 1970, the average ratio of compaction/subsidence was 67 percent, indicating that one-third of the compaction was occurring below the extensometer depth of $760 \mathrm{ft}$. The extensometer measured $1.03 \mathrm{ft}$ of compaction from January 29, 1970, the latest leveling, through December 1979.

Records for extensometers 23/25-16N3, $430 \mathrm{ft}$ deep, and $16 \mathrm{N4}, 250 \mathrm{ft}$ deep, are also shown in table 6. For the period 1962-70, 2 percent of the measured subsidence occurred above $250 \mathrm{ft}, 20$ percent above $430 \mathrm{ft}$, and 59 percent above $760 \mathrm{ft}$.

At extensometer 24/26-36A2, 2,200 ft deep, the compaction/subsidence ratio was more than 100 percent from January 1962 to February 1970. Because this discrepancy was due to mechanical problems at the site, it was not listed in table 6. 
At extensometer site 24/26-34F1, 1,510 ft deep, $2^{1 / 2}$ mi west of 24/26-36A2, measured compaction equaled 71 percent of the subsidence from February 1959 to February 1970.

At extensometer site $11 \mathrm{~N} / 21 \mathrm{~W}-3 \mathrm{~B} 1,1,480 \mathrm{ft}$ deep, measured compaction equaled 87 percent of the subsidence from February 1965 to March 1978. As discussed earlier in this report in the section on "Monitoring along the California Aqueduct," the 1975-78 compaction data are questionable, owing to flooding.

A. K. Williamson (oral commun., 1981, U.S. Geological Survey) noted an interesting relationship in the San Joaquin Valley between extensometer depth and the compaction/subsidence ratio as illustrated in figure 67 . ("Long-term" compaction/subsidence ratios based on the full period of available record were used in preparing this figure.) This relationship is surprisingly good considering that it includes locations all over the valley with different sediments, confining layers, pumpage, and well depths. Several inferences may be drawn from this relation. Almost all the compaction due to ground-water withdrawal occurs at depths between 350 to $2,200 \mathrm{ft}$. This is not surprising because most of the water is withdrawn from this interval. Between these depths, the compaction/subsidence ratio is shown to approximate a linear function of the logarithm of the depth. The least squares regression equation of this function has an $R$ squared value of 0.76 , which indicates that 76 percent of the variation of the ratio is explained by the equation, whereas 24 percent of its variation is random (or attributable to other factors not considered).

For example, on the basis of the relation shown on figure 67, a 1,000-ft extensometer in a subsidence area in the San Joaquin Valley would record approximately 58 percent of the total subsidence measured at the well site. A 2,000-ft extensometer would record nearly 100 percent of the total subsidence measured at the well site. This relation of the extensometer depth to the compaction/ subsidence ratio implies that substantial head decline has extended to depths of roughly $2,000 \mathrm{ft}$ within the confined aquifer in all subsiding areas of the San Joaquin Valley. This implication apparently applies, at least crudely, even in areas where most irrigation wells are substantially less than $2,000 \mathrm{ft}$ deep.

It should be noted, however, that much of the control on the deep end of the curve is provided by the three oiltest wells in the Los Banos-Kettleman City area that were converted to extensometer wells and that measure casing deformation due to aquifer compaction. Two of these wells, 19/16-23P2 (depth 2,200 ft) and 20/18-11Q3 (depth 1,930 ft), appear to measure nearly 100 percent of the subsidence (fig. 67). However, as shown in table 6, the compaction/subsidence ratios are somewhat inconsistent, perhaps because of the time variations in the failure characteristics (buckling and (or) shearing) of the deforming casings. Both of these extensometers occasionally produced erratic records that were probably related to intermittent casing failures; compensating adjustments in the data were considered necessary, but the accuracy of the compensations is open to question. The third oiltest well converted to an extensometer well, 17/15-14Q1 (depth $2,315 \mathrm{ft}$ ), measured only 75 percent of the subsidence from 1971 to 1975.

\section{SUGGESTIONS FOR CONTINUED MONITORING}

Monitoring subsidence in the San Joaquin Valley solely by repeated network releveling is difficult and costly because of the large area affected by land subsidence. Monitoring subsidence by occasional releveling of the network and by continuing operation of deep-well extensometers and water-level recorders at selected locations is suggested as the most efficient and economical method in this area.

The authors suggest that consideration be given to the following program:

1. Within the next 2-3 years (1983-84), relevel the valleywide subsidence network, preferably at the time the California Department of Water Resources relevels the California Aqueduct. In addition to releveling the networks in the three principal subsidence areas, this survey should include extension of the networks to known subsiding areas not now adequately covered, principally the El Nido area, the Hanford area, and the developing area south of Richgrove and east of State Highway 65.

2. Then, relevel at 5-10-year intervals, as necessary, relying primarily on (a) extensometer and water-level data, (b) other leveling in the valley, such as along the California Aqueduct, (c) amount of surface water available, and (d) ground-water pumpage to determine the need and time for releveling.

3. Continue the present field program of monitoring subsidence using deep-well extensometers and water-level observation wells, as the least costly method of surveillance between relevelings. The monitoring program should be reviewed periodically. This review should include consideration of the geographic coverage of extensometer wells relative to subsidence severity, the depths of extensometer wells relative to the depth interval of compacting deposits, and the perforated intervals of observation wells, relative to the thickness in- 
tervals measured by the extensometers. Consideration also should be given to replacing extensometer wells, to replacing extensometer cables with pipes to improve the accuracy of the measurements, to replacing, at some sites, the entire installation with a well of more suitable construction, and, finally, to constructing at a few strategic sites extensometers that penetrate the full thickness of compacting sediments.

\section{SELECTED REFERENCES}

Bull, W. B., 1964a, Alluvial fans and near-surface subsidence in western Fresno County, California: U.S. Geological Survey Professional Paper 437-A, $71 \mathrm{p}$.

1964b, Geomorphology of segmented alluvial fans in western Fresno County, California: U.S. Geological Survey Professional Paper 352-E, p. 89-129.

1972, Prehistoric near-surface subsidence cracks in western Fresno County, California: U.S. Geological Survey Professional Paper 437-C, 85 p.

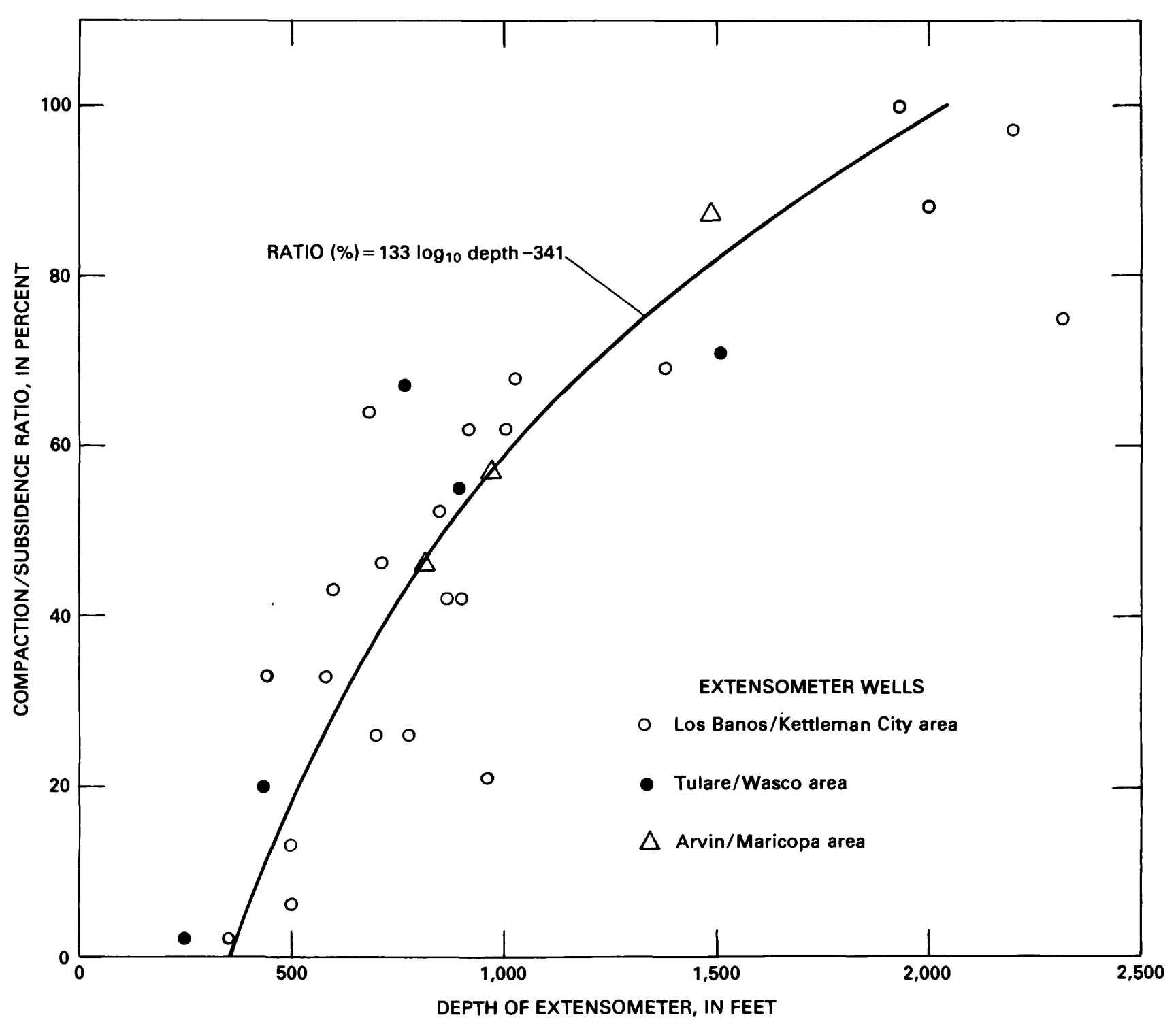

FIGURE 67.-Relation of compaction/subsidence ratios to depth at extensometer wells in the San Joaquin Valley. 
1975, Land subsidence due to ground-water withdrawal in the Los Banos-Kettleman City area, California. Part 2, Subsidence and compaction of deposits: U.S. Geological Survey Professional Paper 437-F, 90 p.

Bull, W. B., and Miller, R. E., 1975, Land subsidence due to groundwater withdrawal in the Los Banos-Kettleman City area, California. Part 1, Changes in the hydrologic environment conducive to subsidence: U.S. Geological Survey Professional Paper 437-E, 71 p.

Bull, W. B., and Poland, J. F., 1975, Land subsidence due to groundwater withdrawal in the Los Banos-Kettleman City area, California. Part 3, Interrelations of water-level change, change in aquifer-system thickness, and subsidence: U.S. Geological Survey Professional Paper 437-G, 62 p.

California Department of Water Resources, 1960, Regional subsidence exploration, debris flow study, in Engineering geology of debris flows along the southwest side of the San Joaquin Valley, California, 1957-59: California Department of Water Resources, Exploration Section Report E-3, 31 p.

1964, Design and construction studies of shallow land subsidence for the California Aqueduct in the San Joaquin Valley-Interim report: California Department of Water Resources, 130 p.

Croft, M. G., 1972, Subsurface geology of the Late Tertiary and Quaternary water-bearing deposits of the southern part of the San Joaquin Valley, California: U.S. Geological Survey Water-Supply Paper 1999-H, 29 p.

Davis, G. H., and Green, J. H., 1962, Structural control of interior drainage, southern San Joaquin Valley, California, in Geological Survey Research 1962: U.S. Geological Survey Professional Paper 450-D, p. D89-D91.

Davis, G. H., Green, J. H., Olmsted, F. H., and Brown, D. W., 1959, Ground-water conditions and storage capacity in the San Joaquin Valley, California: U.S. Geological Survey Water-Supply Paper $1469,287 \mathrm{p}$.

Davis, G. H., Lofgren, B. E., and Mack, Seymour, 1964, Use of groundwater reservoirs for storage of surface water in the San Joaquin Valley, California: U.S. Geological Survey Water-Supply Paper 1618, $125 \mathrm{p}$.

Davis, G. H., and Poland, J. F., 1957, Ground-water conditions in the Mendota-Huron area, Fresno and Kings Counties, California: U.S. Geological Survey Water-Supply Paper 1360-G, p. 409-588.

Hall, C. E., and Carlson, J. W., 1965, Stabilization of soils subject to hydrocompaction: Association of Engineering Geologists Bulletin, v. 2, no. 2, p. 47-58.

Harris, R. M., 1977, Ground-water use during the drought: Regional Water Users Conference, 11th, Fresno, Calif., 1978, 3 p.

Helm, D. C., 1975, One-dimensional simulation of aquifer-system compaction near Pixley, California. 1, Constant parameters: Water Resources Research, v. 11, no. 3, p. 465-478.

1976, One-dimensional simulation of aquifer-system compaction near Pixley, California. 2, Stress-dependent parameters: Water Resources Research, v. 12, no. 3, p. 375-391.

1977, Estimating parameters of compacting fine-grained interbeds within a confined aquifer system of one-dimensional simulation of field observations, in International Symposium on Land Subsidence, 2d, Anaheim, California 1976, Proceedings: International Association of Hydrological Sciences Publication 121, p. $145-156$.

1978, Field verification of a one-dimensional mathematical model for transient compaction and expansion of a confined aquifer system, in Specialty Conference on Verification of Mathematical and Physical Models in Hydraulic Engineering, College Park, Maryland 1978, Proceedings: American Society of Civil Engineers, p. 189-196.

Inter-Agency Committee on Land Subsidence in the San Joaquin Valley, 1955, Proposed program for investigating land subsidence in the
San Joaquin Valley: Inter-Agency Committee on Land Subsidence in the San Joaquin Valley, Sacramento, Calif., 60 p.

1958, Progress report on land-subsidence investigations in the San Joaquin Valley, California, through 1957: Inter-Agency Committee on Land Subsidence in the San Joaquin Valley, Sacramento, Calif., 160 p.

Johnson, A. I., Moston, R. P., and Morris, D. A., 1968, Physical and hydrologic properties of water-bearing deposits in subsiding areas in central California: U.S. Geological Survey Professional Paper 497-A, $71 \mathrm{p}$.

Lofgren, B. E., 1960, Near-surface land subsidence in western San Joaquin Valley, California: Journal of Geophysical Research, v. 65, no. 3, p. 1053-1062.

1961, Measurement of compaction of aquifer systems in areas of land subsidence, in Geological Survey Research 1961: U.S. Geological Survey Professional Paper 424-B, p. B49-B52.

1963, Land subsidence in the Arvin-Maricopa area, San Joaquin Valley, California, in Geological Survey Research 1963: U.S. Geological Survey Professional Paper 475-B, p. B171-B175.

1966, Tectonic movement in the Grapevine area, Kern County, California, in Geological Survey Research 1966: U.S. Geological Survey Professional Paper 550-B, p. B6-B11.

1968, Analysis of stresses causing land subsidence, in Geological Survey Research 1968: U.S. Geological Survey Professional Paper 600-B, p. B219-B225.

1969, Land subsidence due to the application of water, in Varnes, D. J., and Kiersch, George, eds., v. 2 of Reviews in Engineering Geology: Boulder, Colo., Geological Society of America, p. 271-303. 1975, Land subsidence due to ground-water withdrawal, ArvinMaricopa area, California: U.S. Geological Survey Professional Paper 437-D, 55 p.

1979, Changes in aquifer-system properties with ground-water depletion, in Evaluation and Prediction of Subsidence: American Society of Civil Engineers, p. 26-46.

Lofgren, B. E., and Klausing, R. L., 1969, Land subsidence due to ground-water withdrawal, Tulare-Wasco area, California: U.S. Geological Survey Professional Paper 437-B, 103 p.

Meade, R. H., 1964, Removal of water and rearrangement of particles during the compaction of clayey sediments-review: U.S. Geological Survey Professional Paper 497-B, 23 p.

1967, Petrology of sediments underlying areas of land subsidence in central California: U.S. Geological Survey Professional Paper 497-C, $83 \mathrm{p}$.

1968, Compaction of sediments underlying areas of land subsidence in central California: U.S. Geological Survey Professional Paper 497-D, $39 \mathrm{p}$.

Miller, R. E., Green, J. H., and Davis, G. H., 1971, Geology of the compacting deposits in the Los Banos-Kettleman City subsidence area, California: U.S. Geological Survey Professional Paper 497-E, $46 \mathrm{p}$.

Mitten, H. T., 1972, Ground-water pumpage, San Joaquin Valley, California, 1967-68: U.S. Geological Survey open-file report, 6 p.

1976, Estimated ground-water pumpage in parts of the San Joaquin Valley, California, 1969-71: U.S. Geological Survey openfile report, 9 p.

1980, Estimated agricultural ground-water pumpage in parts of the San Joaquin Valley, California, 1975-77: U.S. Geological Survey Open-File Report 80-1281, 11 p.

Mitten, H. T., and Ogilbee, William, 1971, Ground-water pumpage in parts of Merced, Madera, Fresno, Kings, and Tulare Counties, California, 1962-66: U.S. Geological Survey open-file report, 8 p.

Ogilbee, William, and Rose, M. A., 1969a, Ground-water pumpage in Kern County, San Joaquin Valley, California, 1962-66: U.S. Geological Survey Basic-Data Compilation, 5 p.

$1969 \mathrm{~b}$, Ground-water pumpage on the west side of the San 
Joaquin Valley, California, 1962-66: U.S. Geological Survey BasicData Compilation, 7 p.

Poland, J. F., and Davis, G. H., 1969, Land subsidence due to withdrawal of fluids, in Varnes, D. J., and Kiersch, George, eds., v. 2 of Reviews of Engineering Geology: Boulder, Colo., Geological Society of America, p. 187-269.

Poland, J. F., and Evenson, R. E., 1966, Hydrogeology and land subsidence, Great Central Valley, California, in Bailey, E. H., ed., Geology of northern California: California Division of Mines and Geology Bulletin 190, p. 239-247.

Poland, J. F., and Ireland, R. L., 1965, Shortening and protrusion of a well casing due to compaction of sediments in a subsiding area in California, in Geological Survey Research 1965: U.S. Geological Survey Professional Paper 525-B, p. B180-B183.

Poland, J. F., Lofgren, B. E., Ireland, R. L., and Pugh, R. G., 1975, Land subsidence in the San Joaquin Valley, California, as of 1972: U.S. Geological Survey Professional Paper 437-H, 78 p.

Poland, J. F., Lofgren, B. E., and Riley, F. S., 1972, Glossary of selected terms useful in studies of the mechanics of aquifer systems and land subsidence due to fluid withdrawal: U.S. Geological Survey Water-Supply Paper 2025, 9 p.

Prokopovich, N. P., 1963, Hydrocompaction of soils along the San Luis Canal alignment, western Fresno County, California, in Abstracts for 1962: Geological Society of America Special Paper 73, p. 60.
1970, Regional Geology, rev. by Prokopovich, N. P.: U.S. Bureau Reclamation Central Valley Project, Drawing Number 805-2081646.

Riley, F. S., 1969, Analysis of borehole extensometer data from central California, in Tison, L. J., ed., Land subsidence, v. 2: International Association of Scientific Hydrology Publication 89, p. 423-431.

1970, Land-surface tilting near Wheeler Ridge, southern San Joaquin Valley, California: U.S. Geological Survey Professional Paper $497-\mathrm{G}, 29 \mathrm{p}$.

Riley, F. S., and McClelland, E. J., 1972, Application of the modified theory of leaky aquifers to a compressible multiple-aquifer system: U.S. Geological Survey open-file report, 96 p.

U.S. Bureau of Reclamation, 1974, Technical record of design and construction, Central Valley Project, West San Joaquin Division, San Luis Unit, California, History, general description, and geology, v. 1; $164 \mathrm{p}$.

1978, 9th Annual Report of Project Effects on Sub-Corcoran Water Levels in the San Luis Service Area, December 1976 to December $1977,11 \mathrm{p}$.

Williamson, A. K., 1982, Evapotranspiration of applied water, Central Valley, California, 1957-78: U.S. Geological Survey Water-Resources Investigations $81-45,56 \mathrm{p}$.

Wood, P. R., and Davis, G. H., 1959 [1960], Ground-water conditions in the Avenal-McKittrick area, Kings and Kern Counties, California: U.S. Geological Survey Water-Supply Paper 1457,141 p. 
FIGURES 41-66 

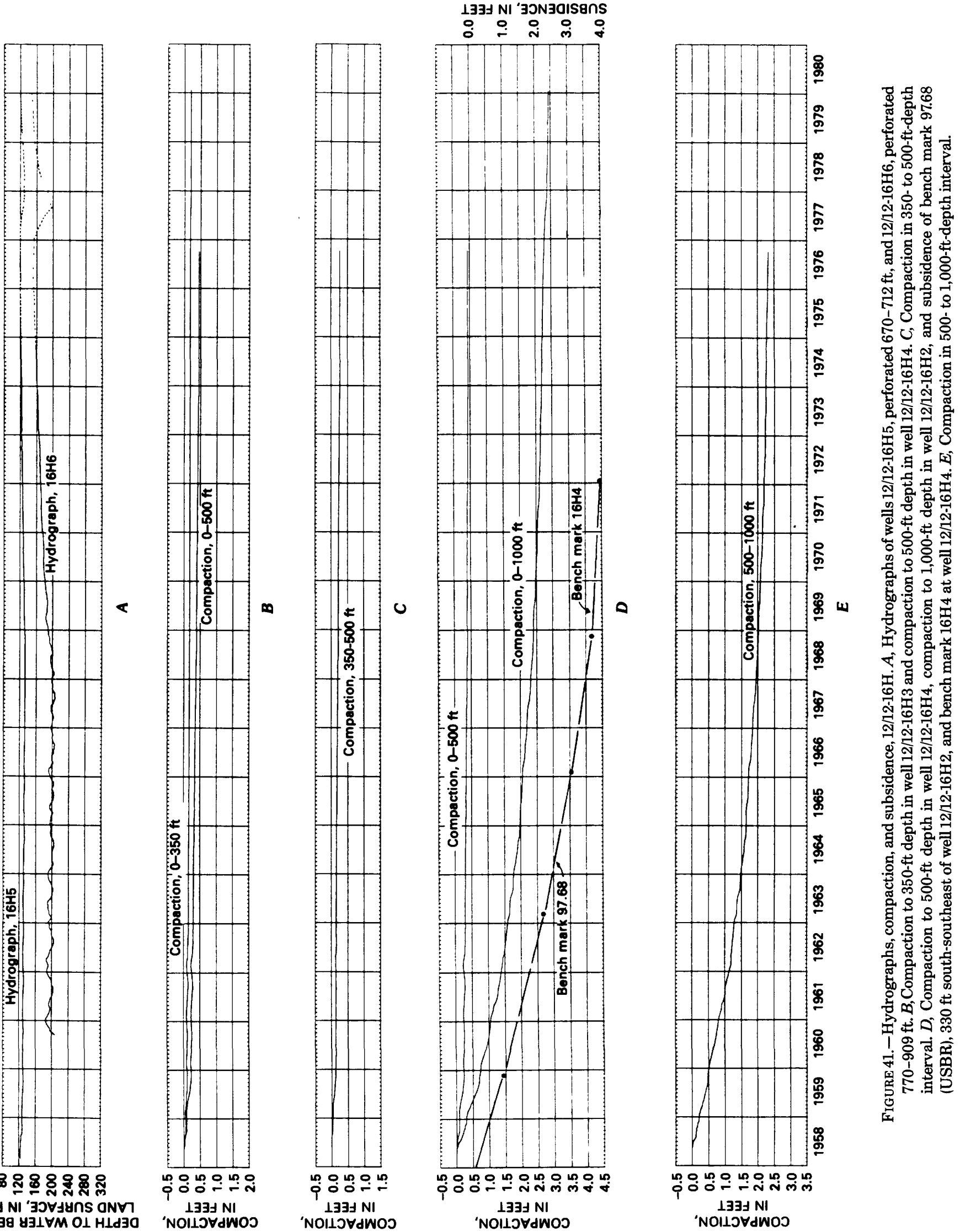

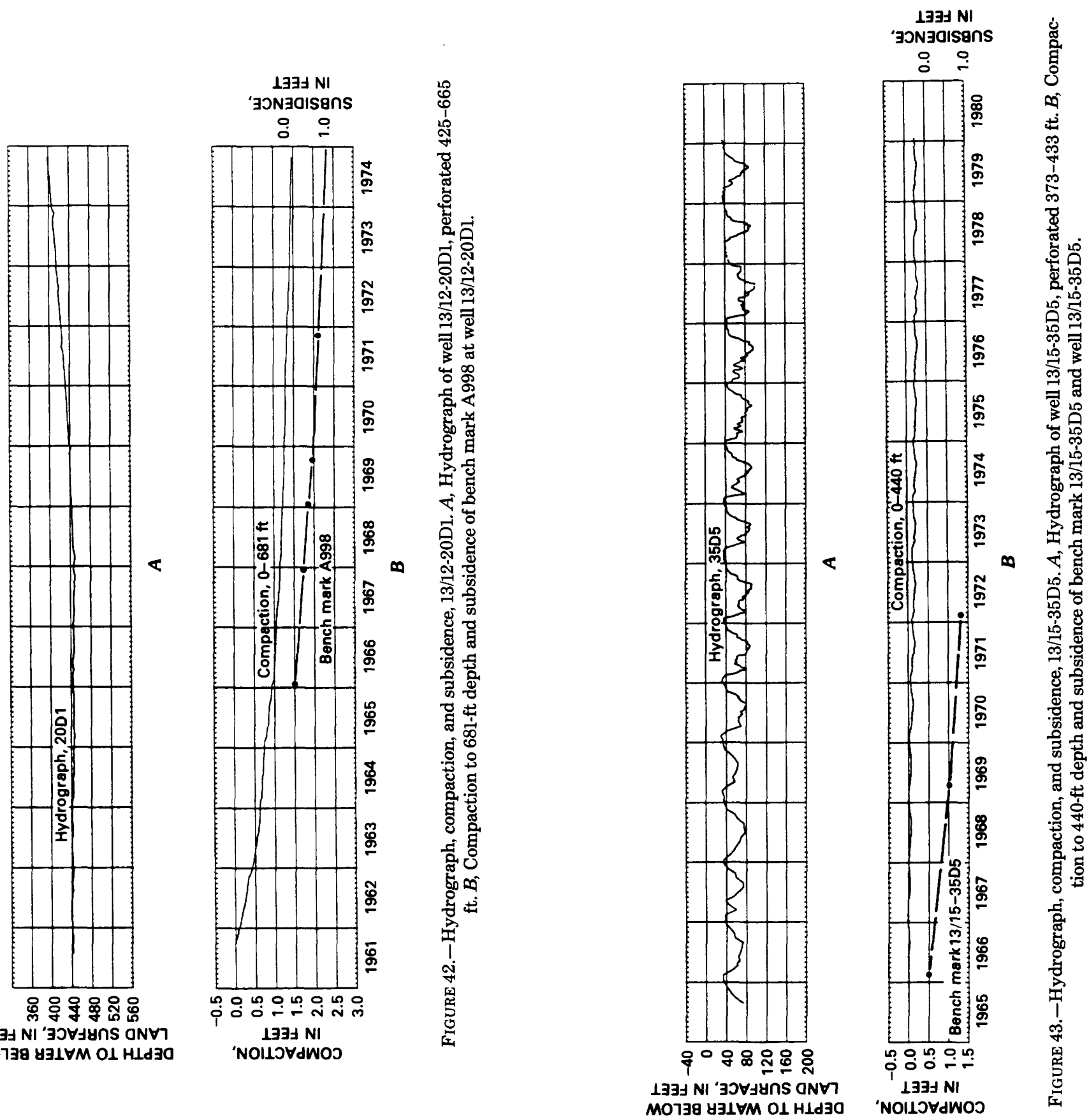


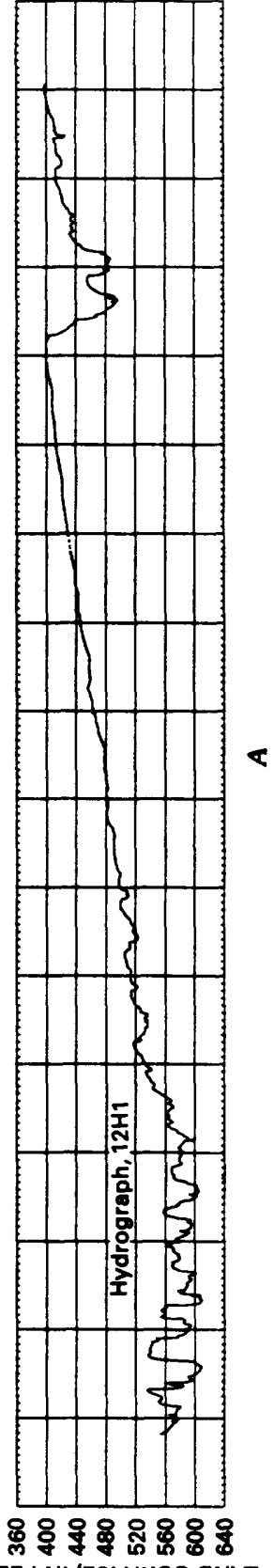

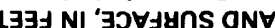

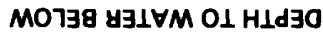
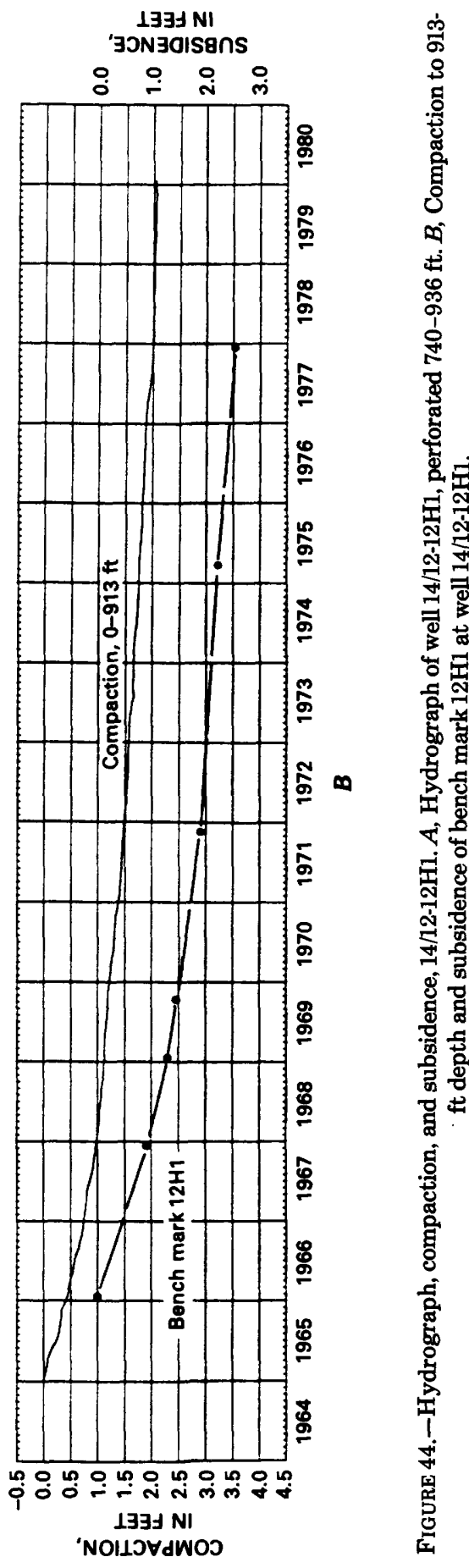

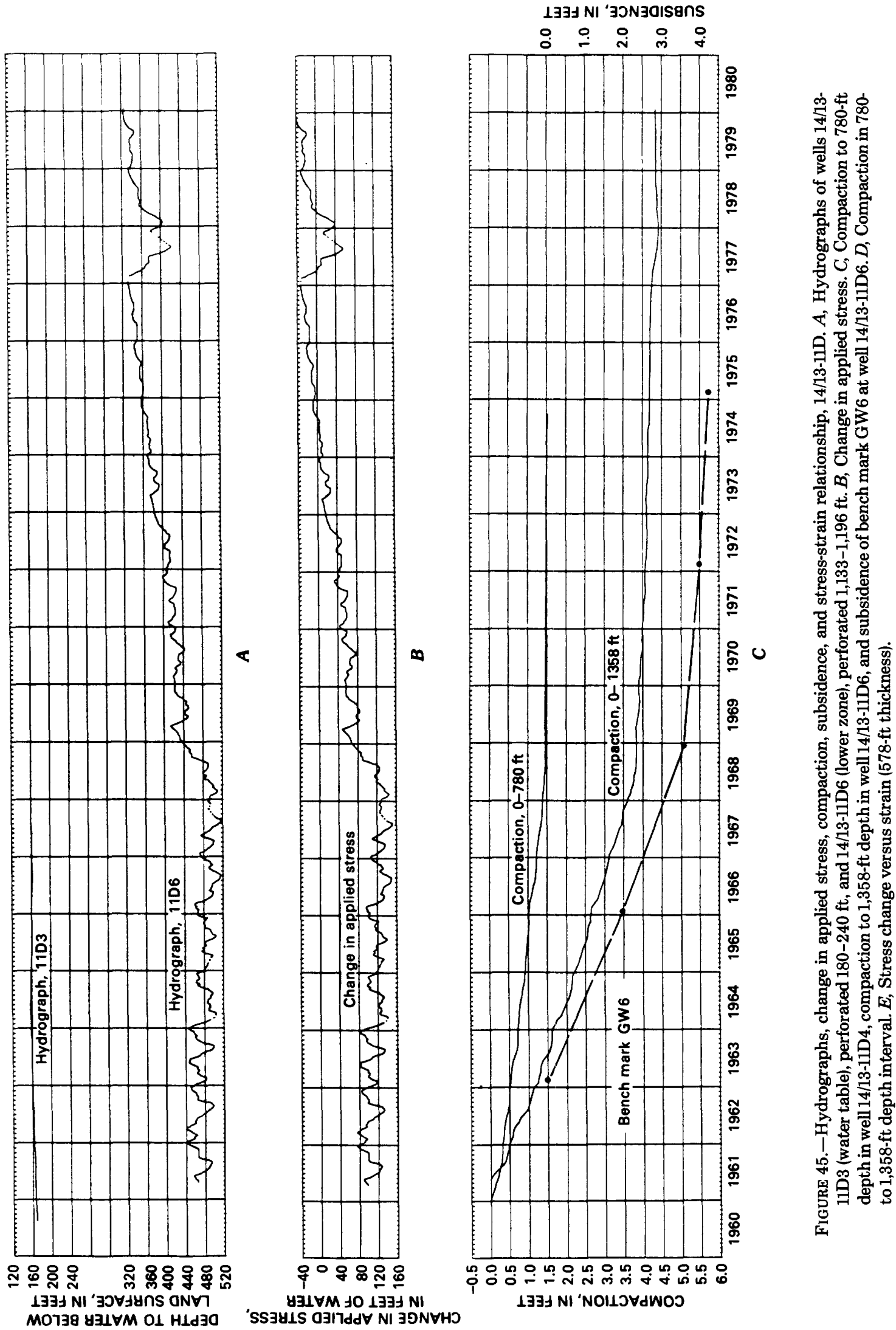

MO738 y $\exists 1 \forall M$ OL HId 30
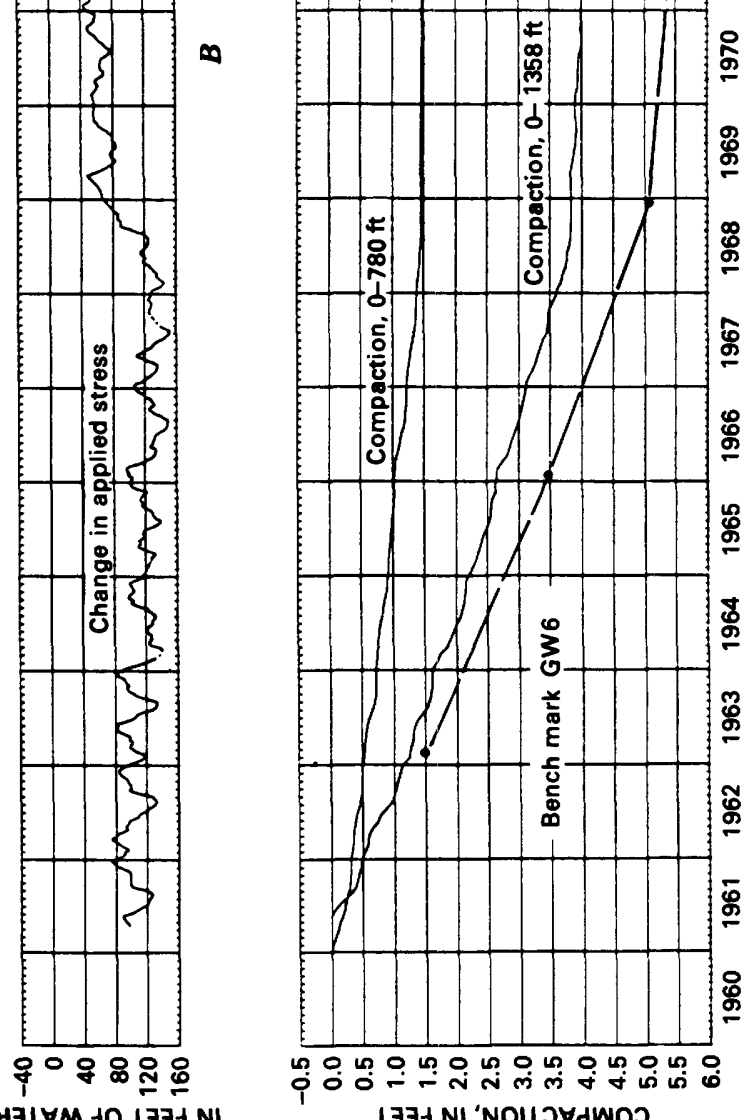

吕 0

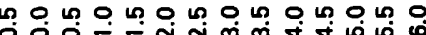



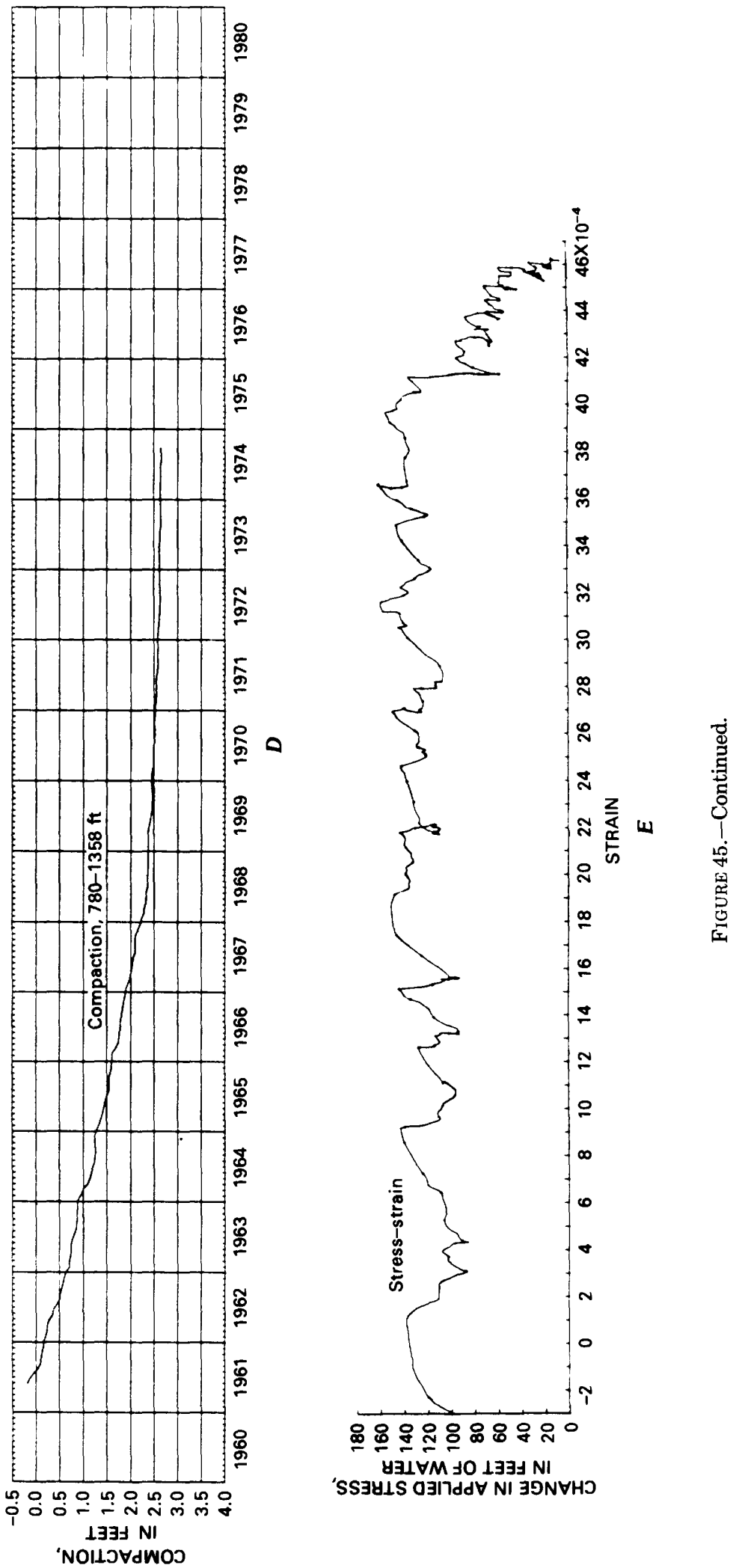


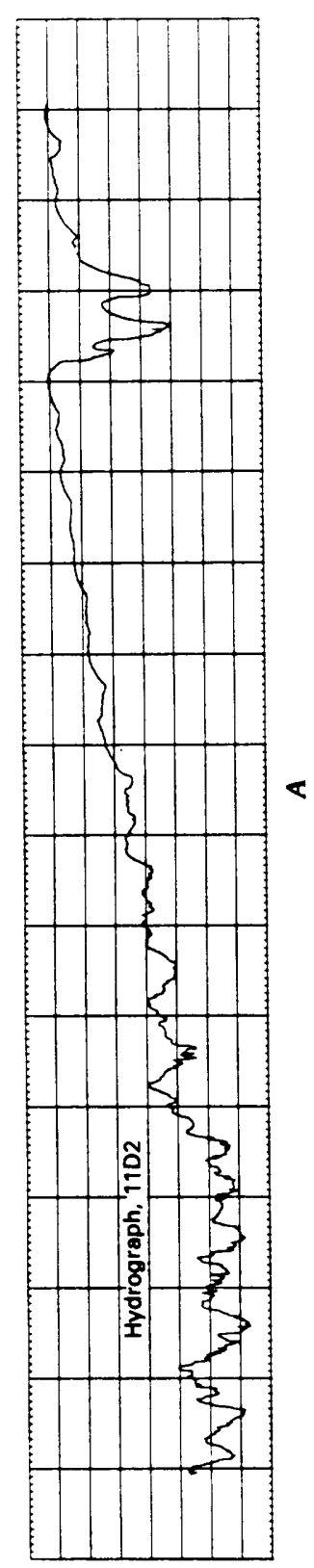

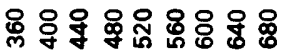

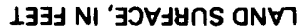
MO738 Y3IYM OL HLIJO
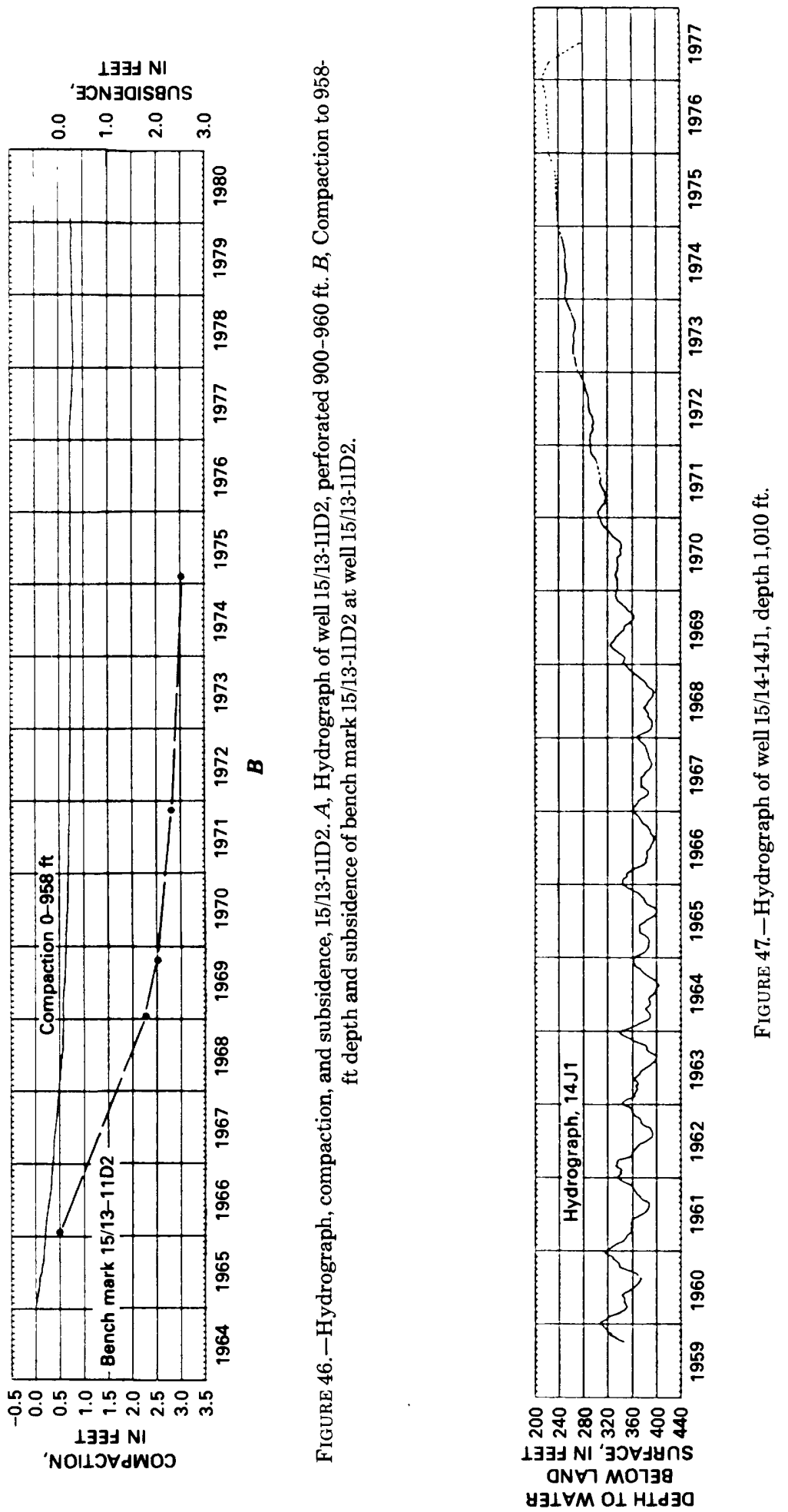


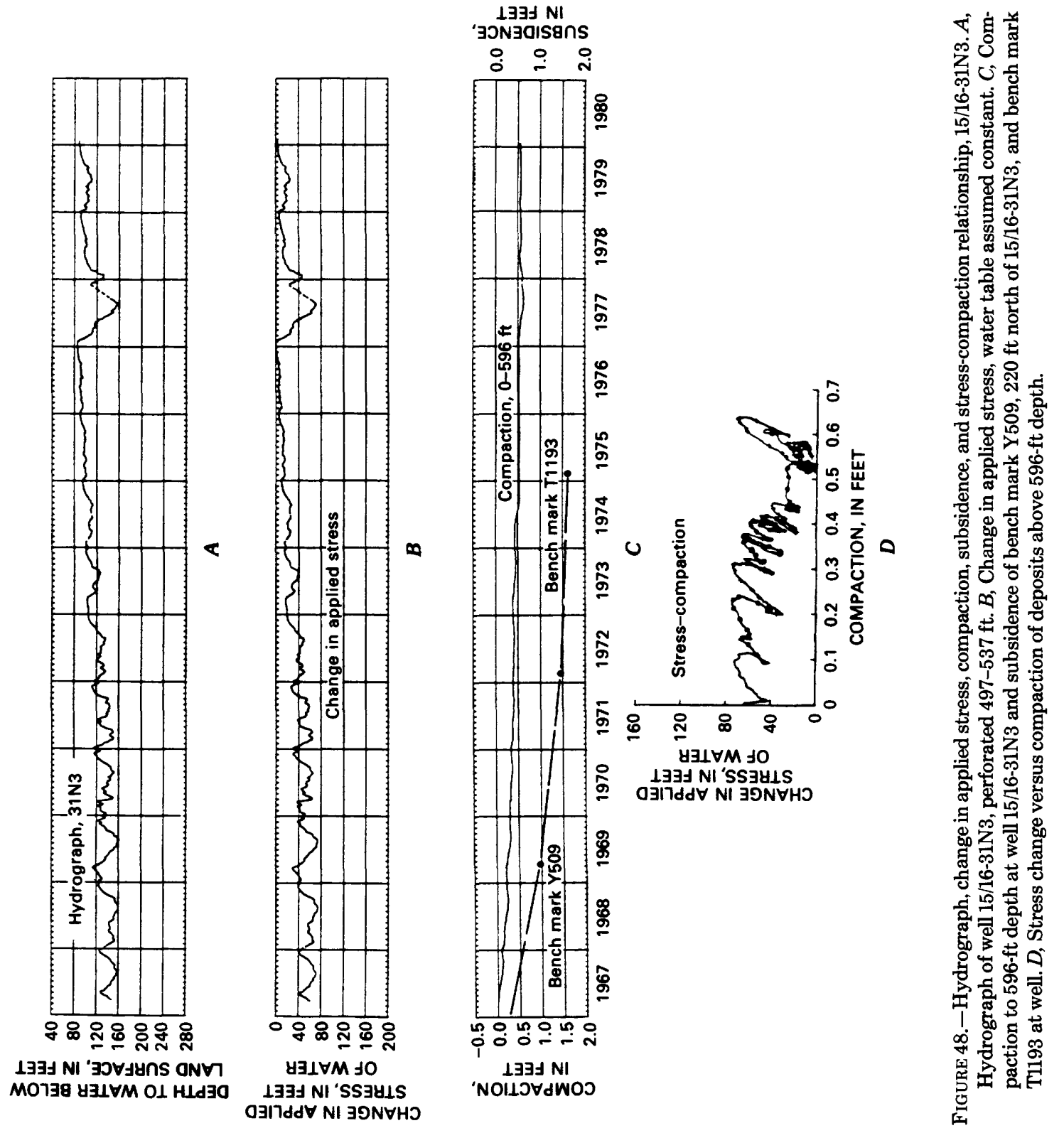




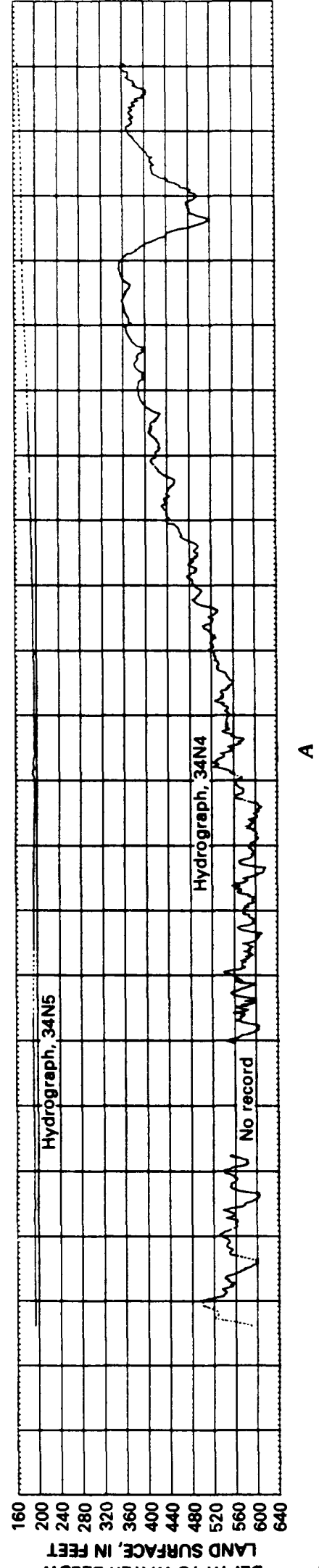

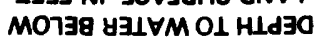

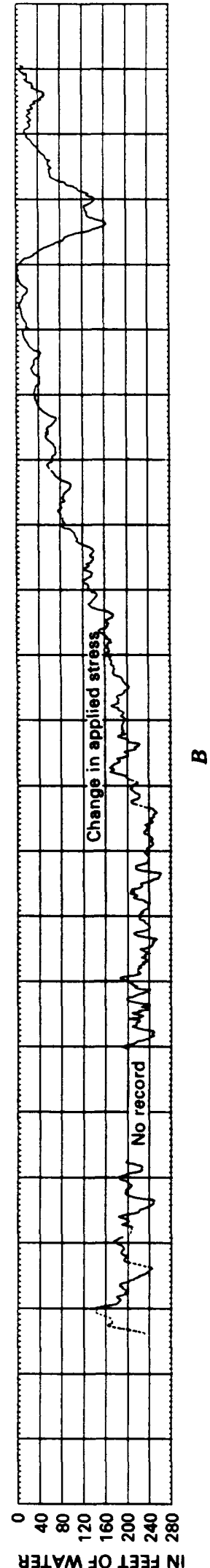

Y3ऽ $\forall M$ JO $\perp \exists \exists \exists ~ N I$

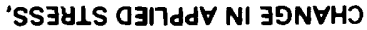
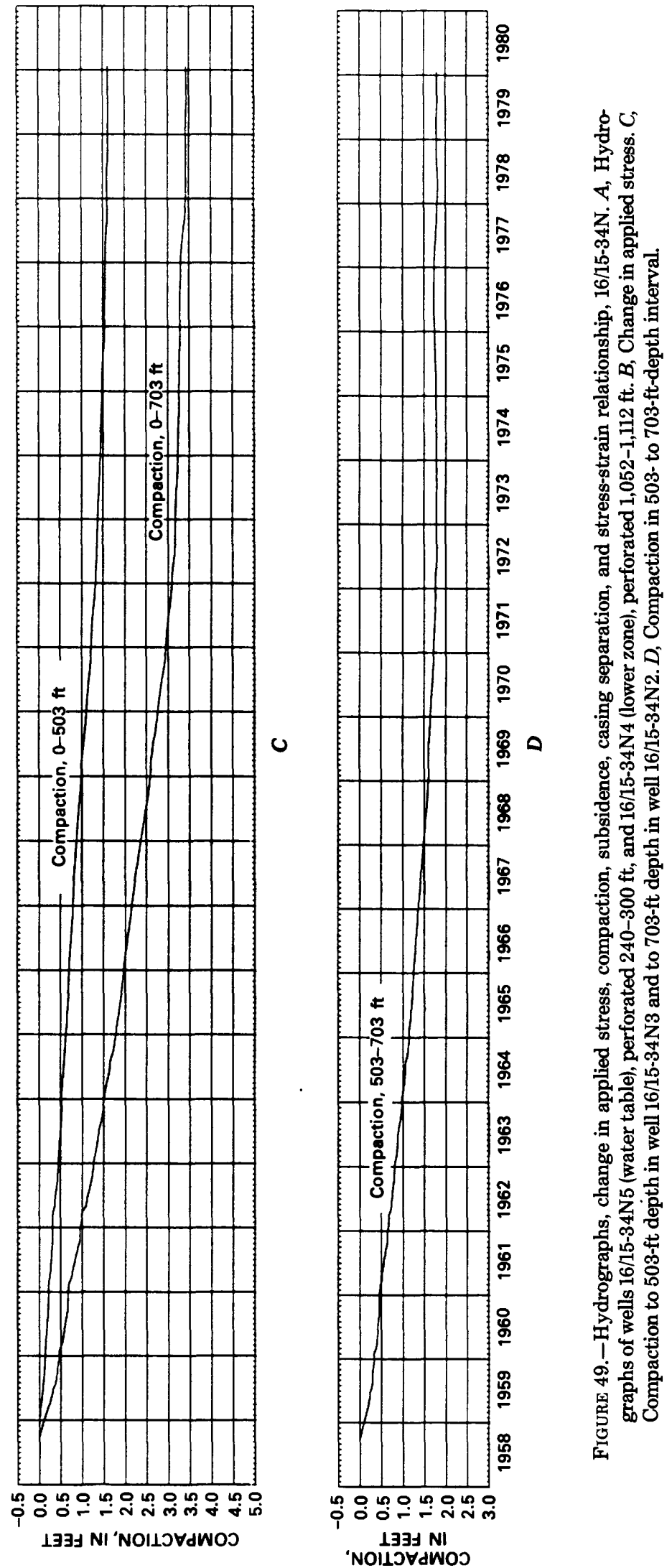


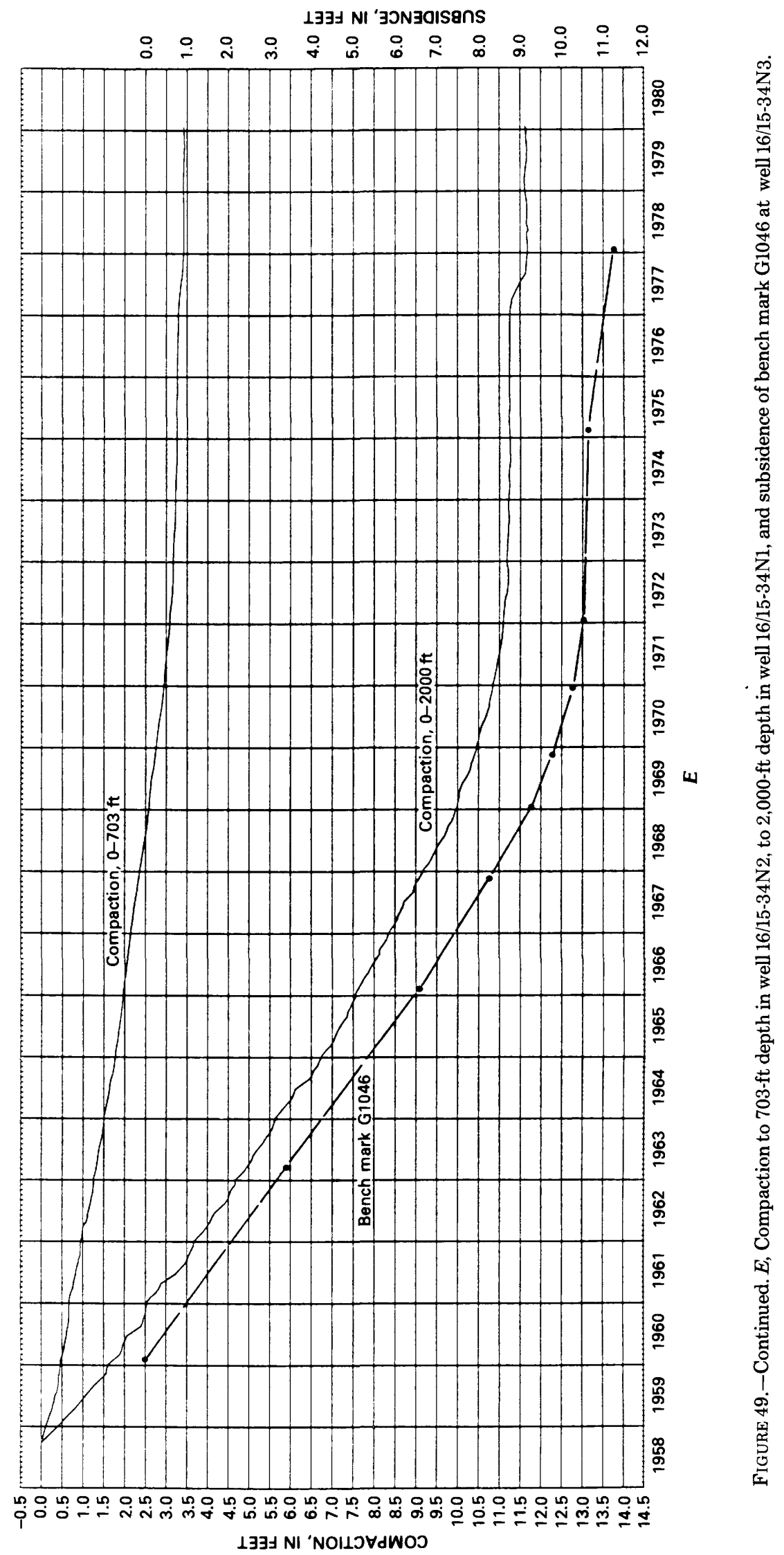



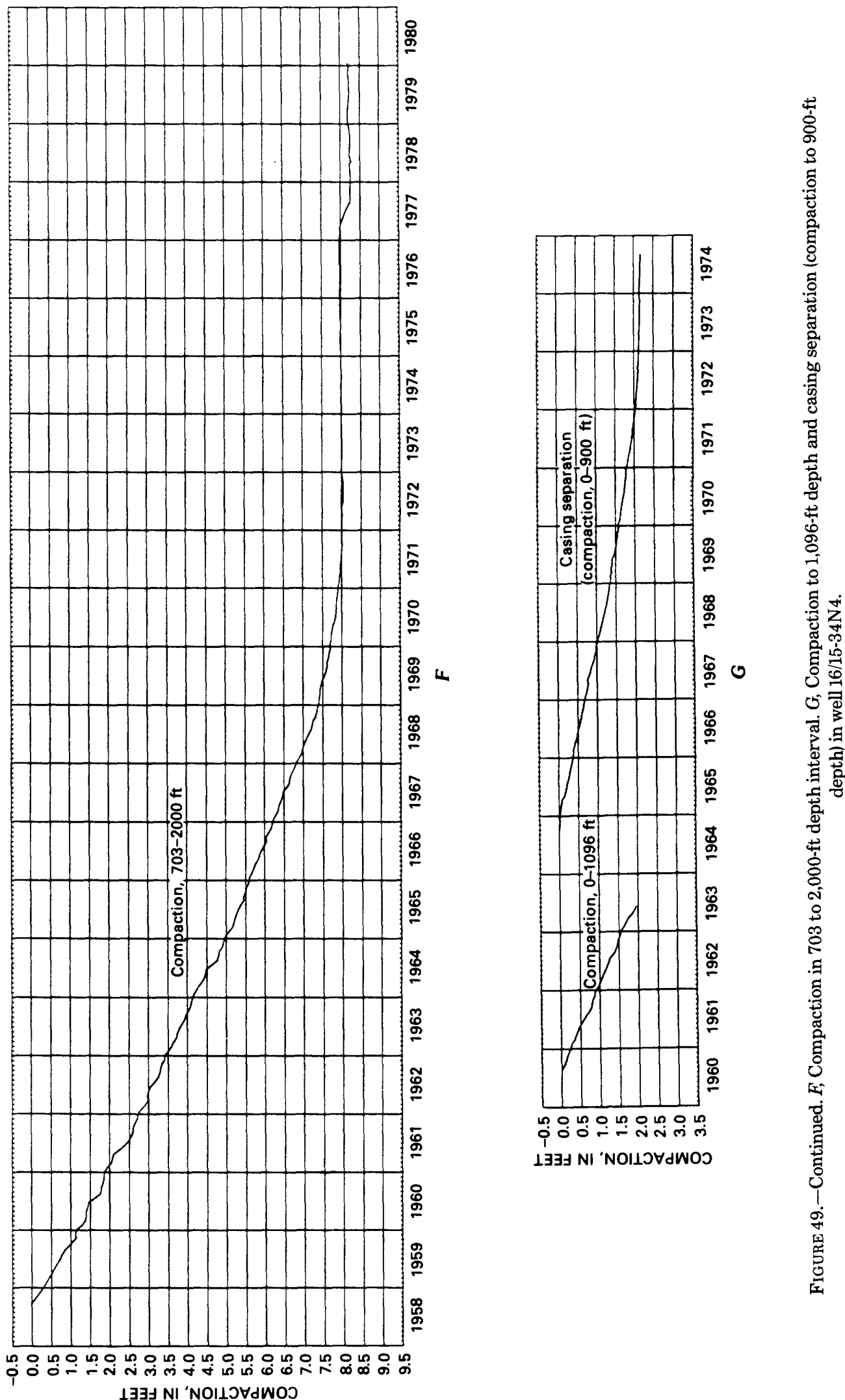


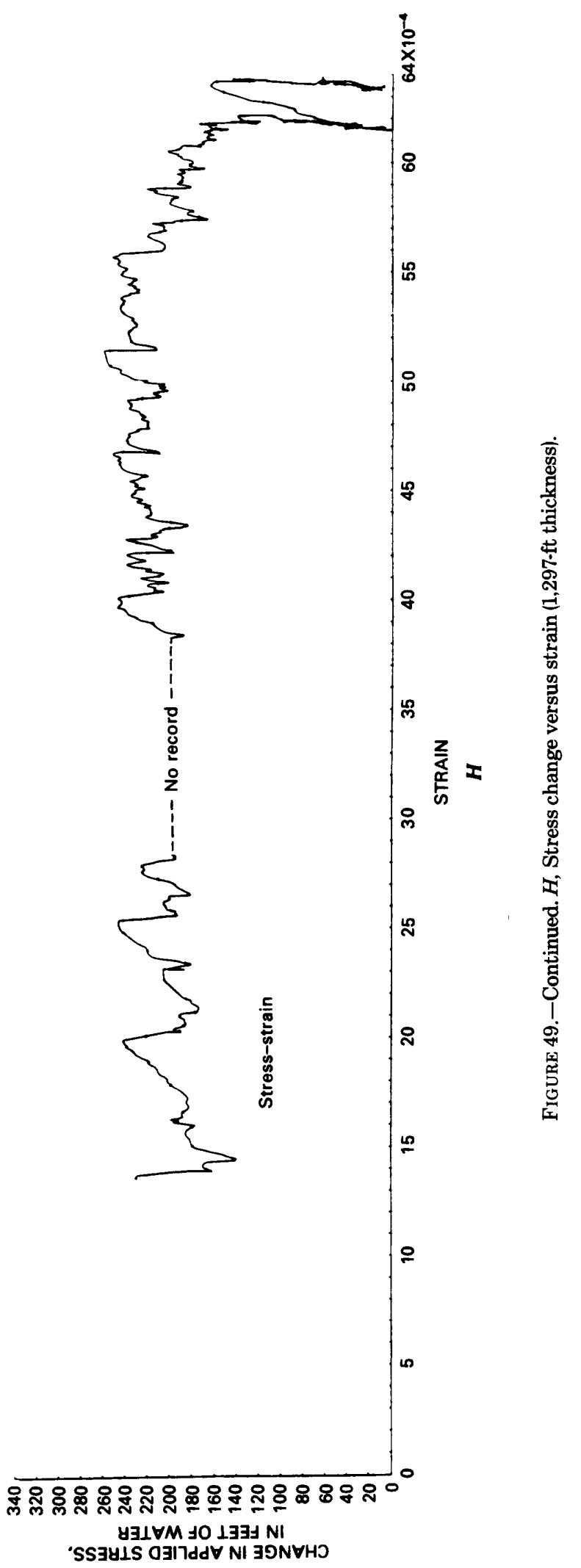



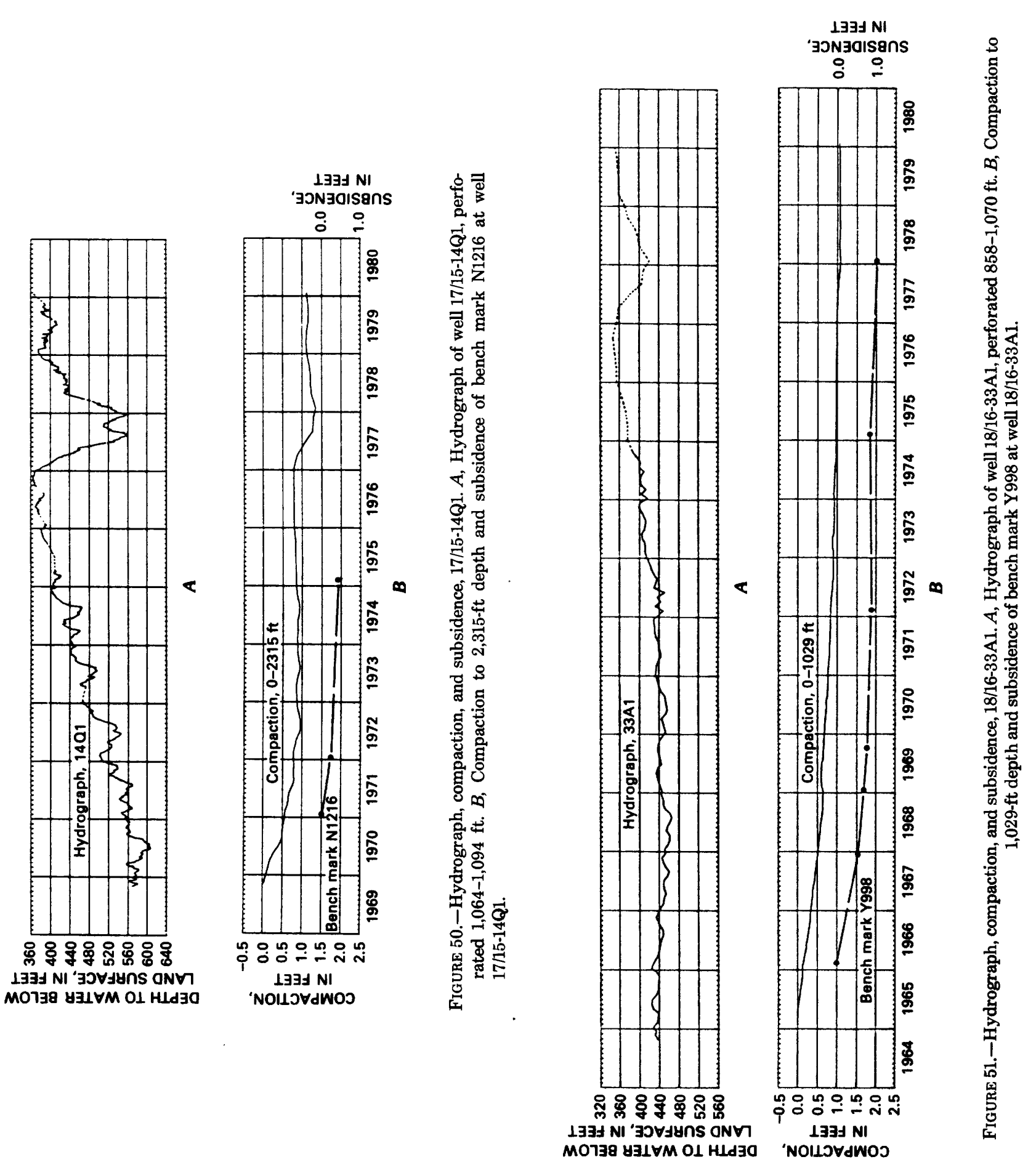


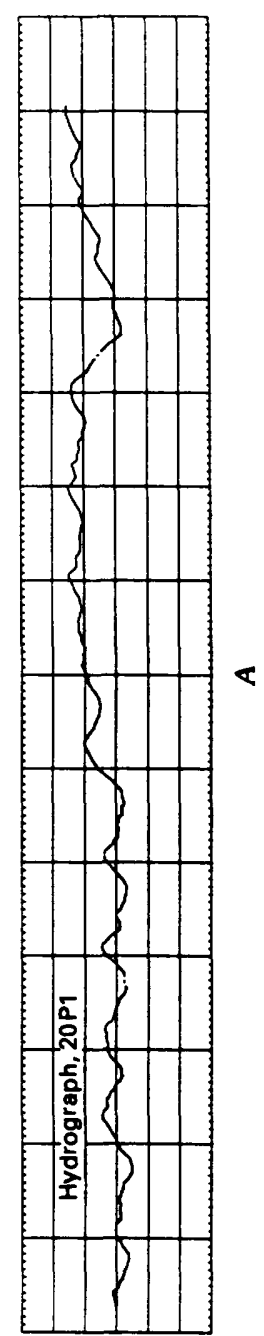

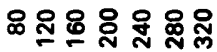

LIJY NI '3OVJUHS ONVI

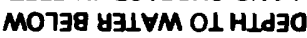
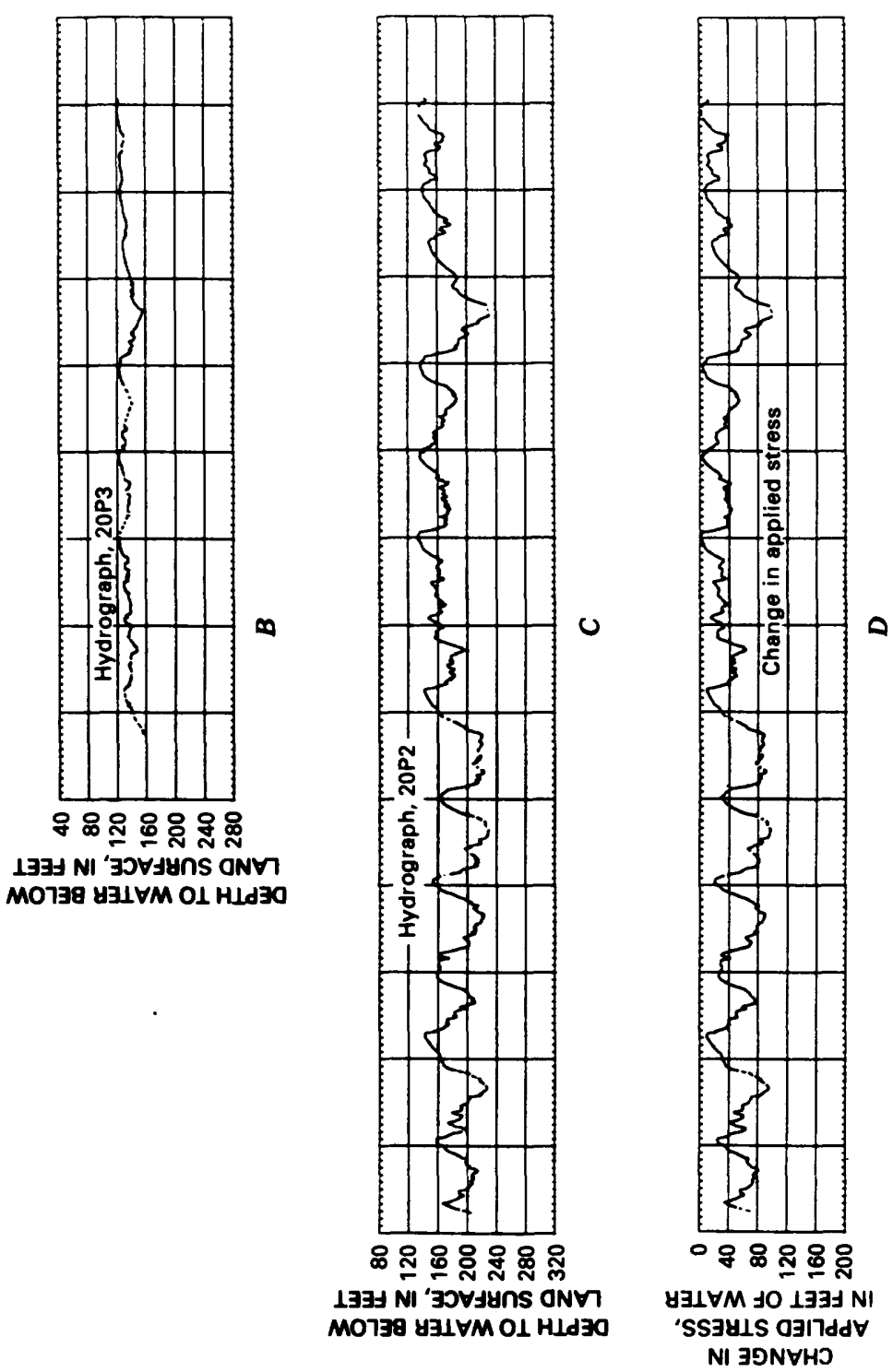


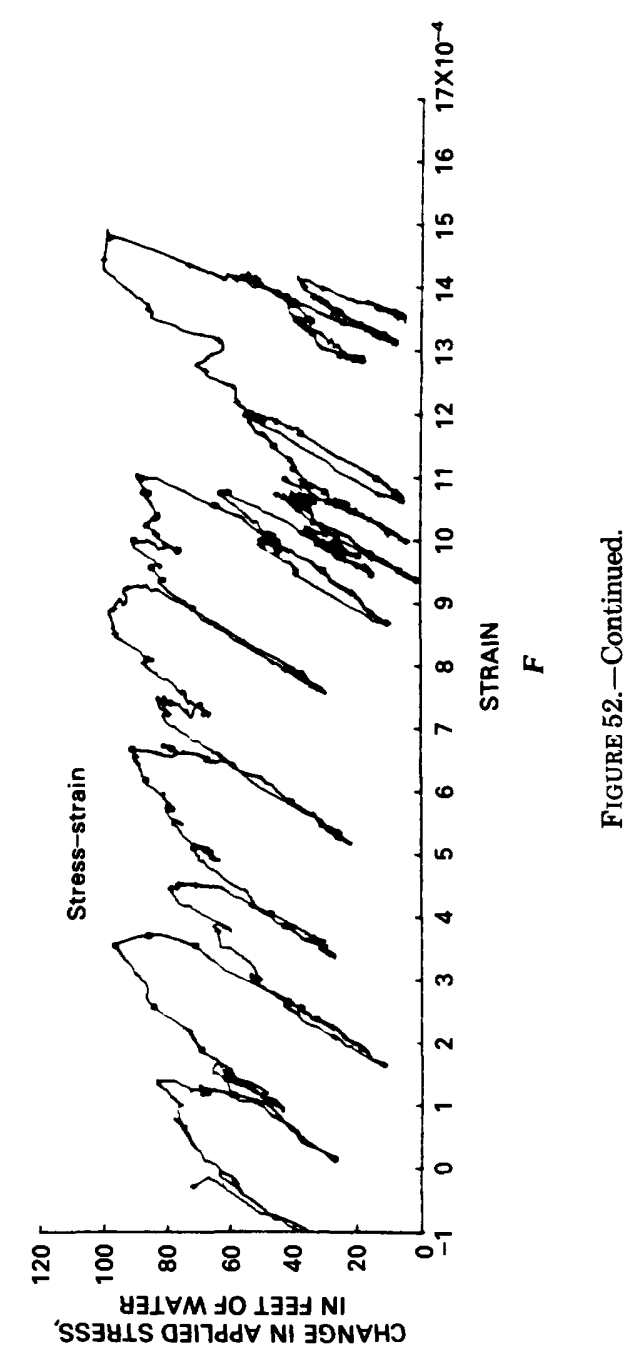




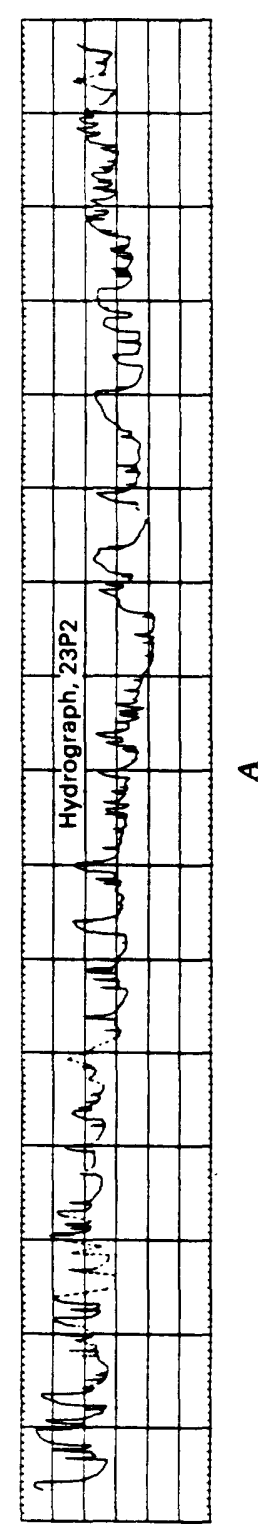

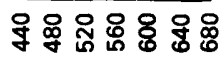

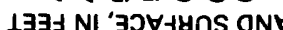

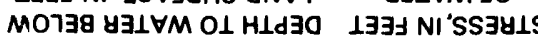
o引Indd $\forall$ NI $\exists$ J N $\forall$ H

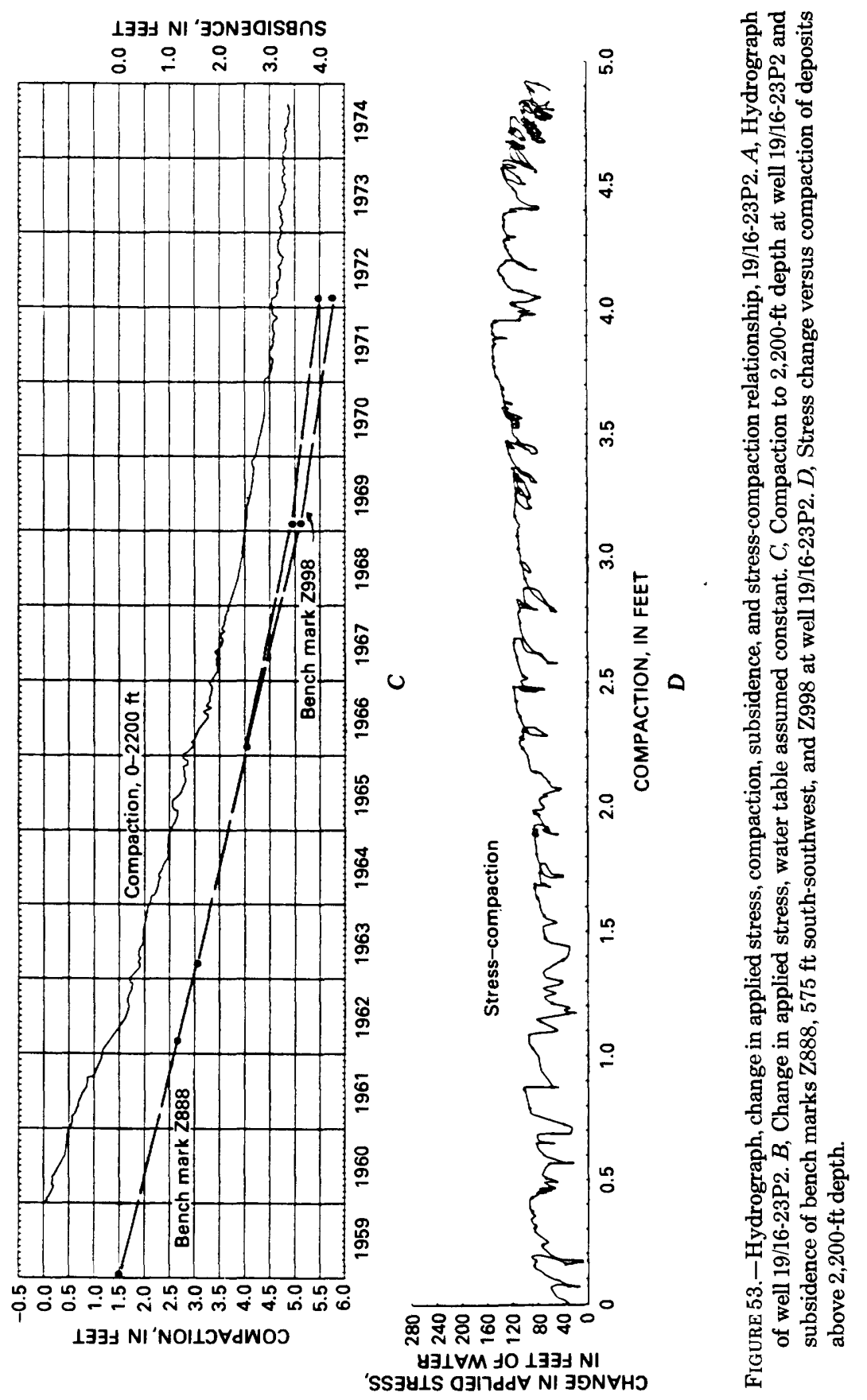



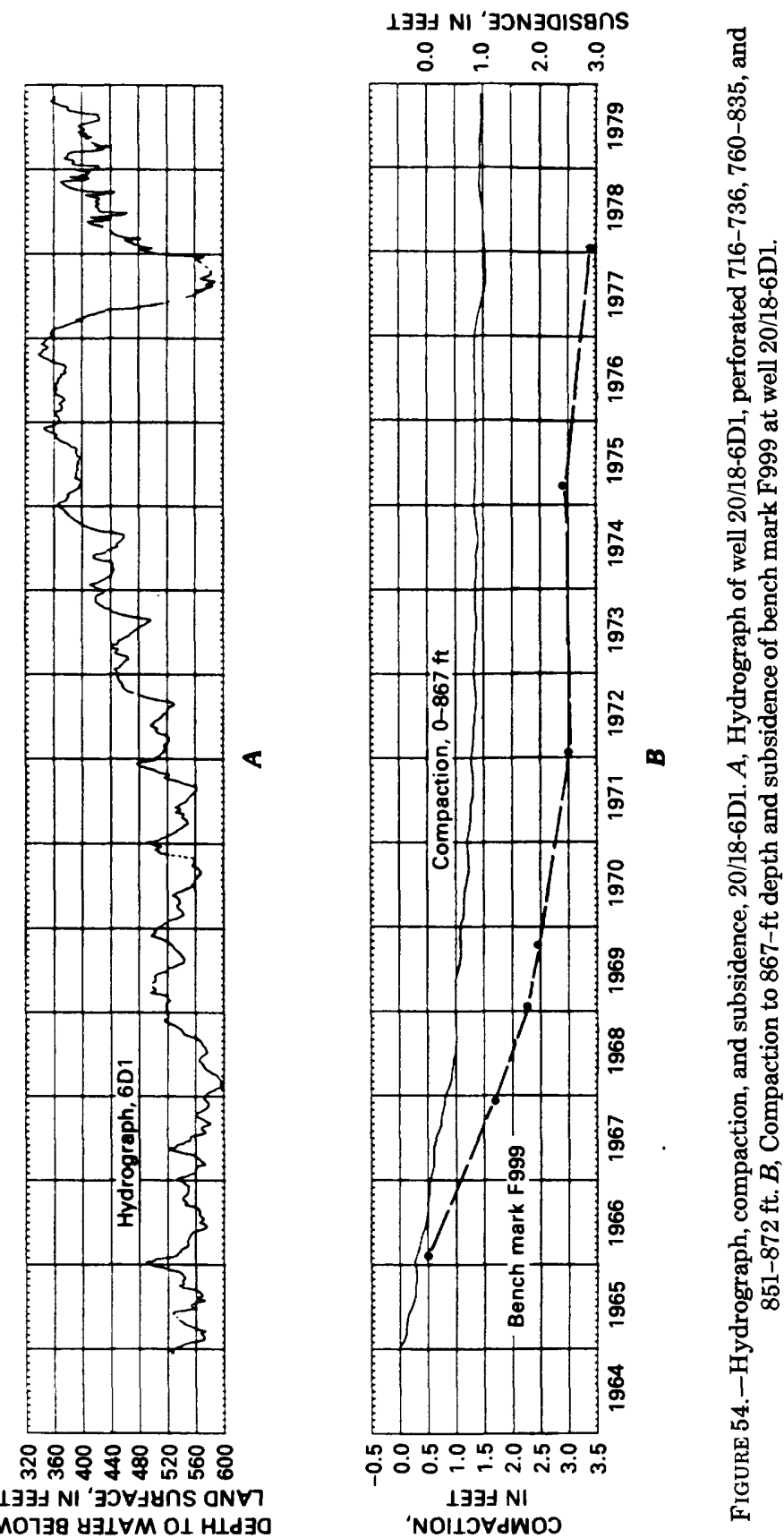

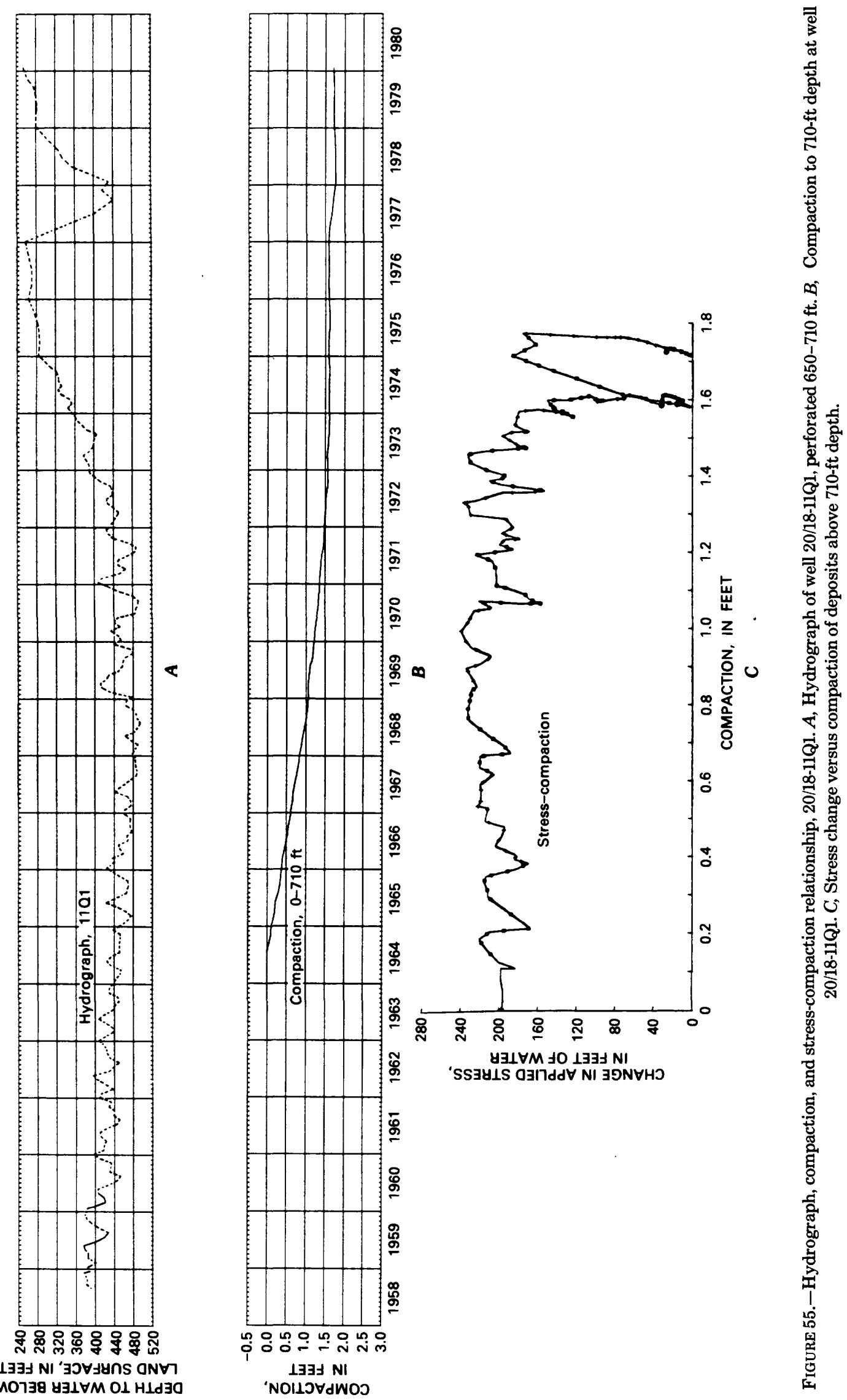


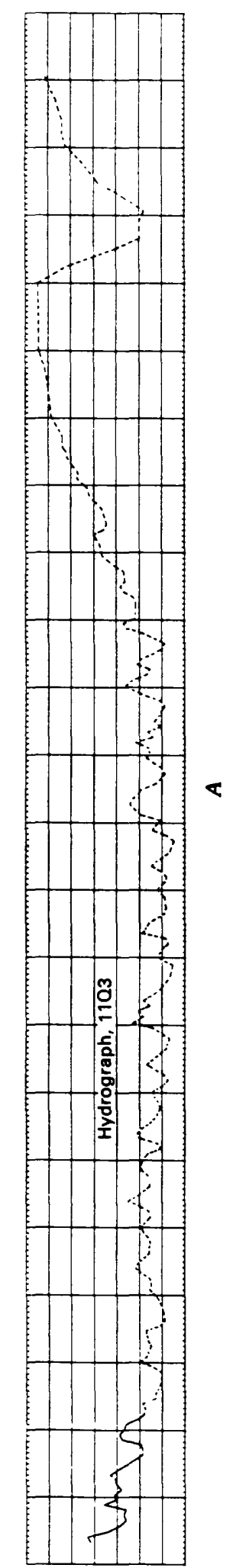

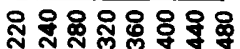

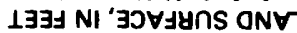
MOT3g y $3 \perp \forall M O \perp H \perp d \exists O$
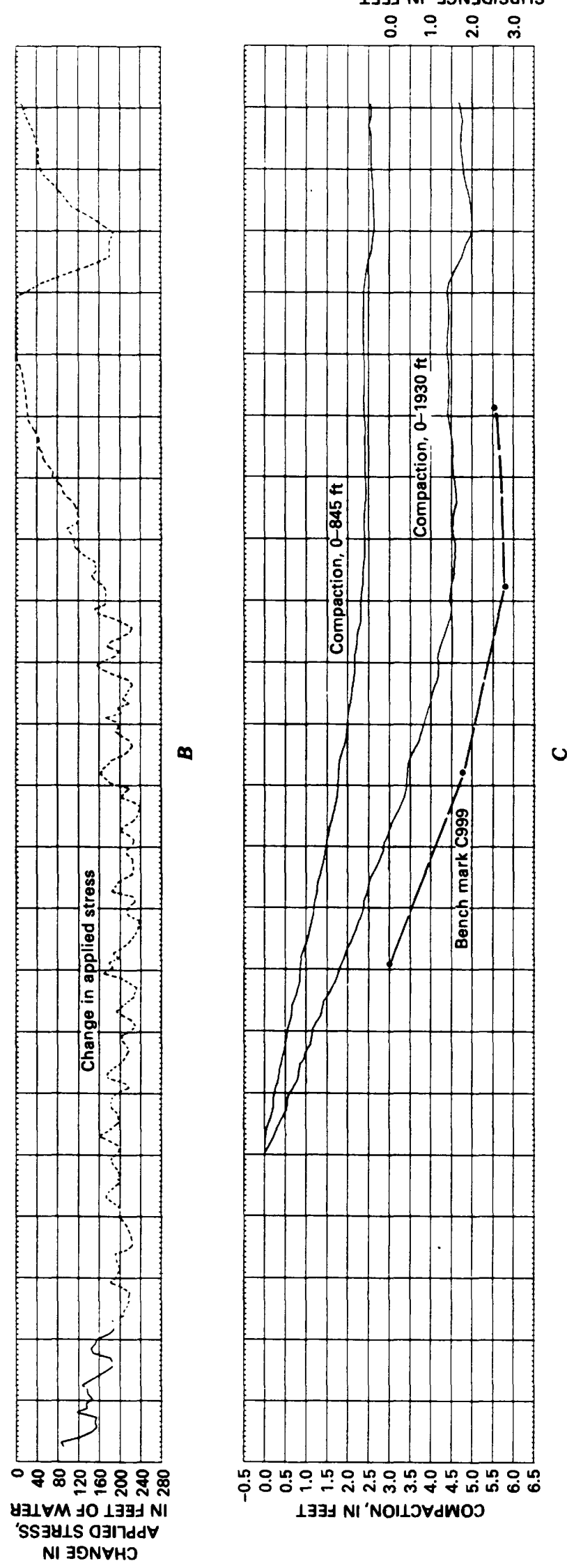


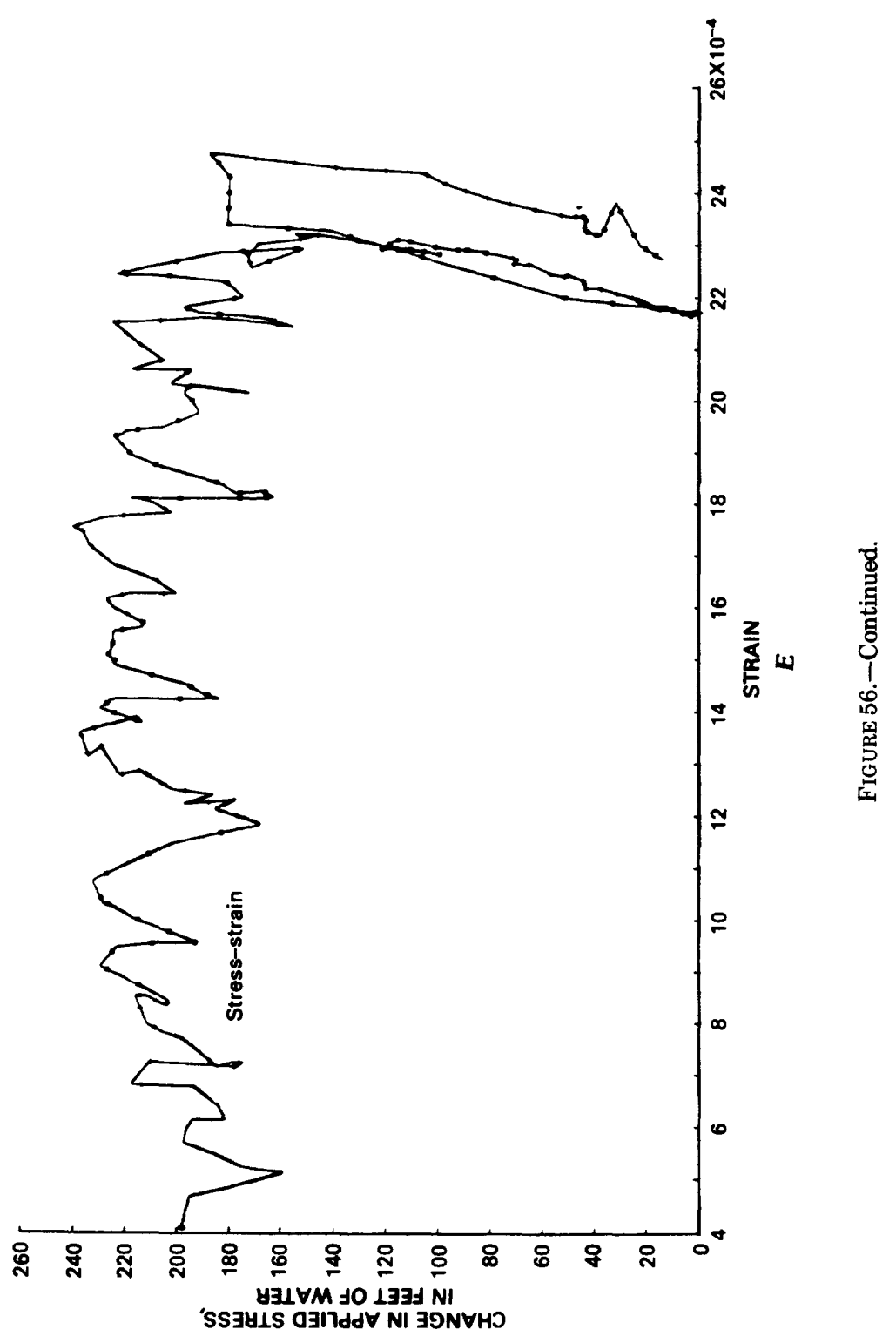




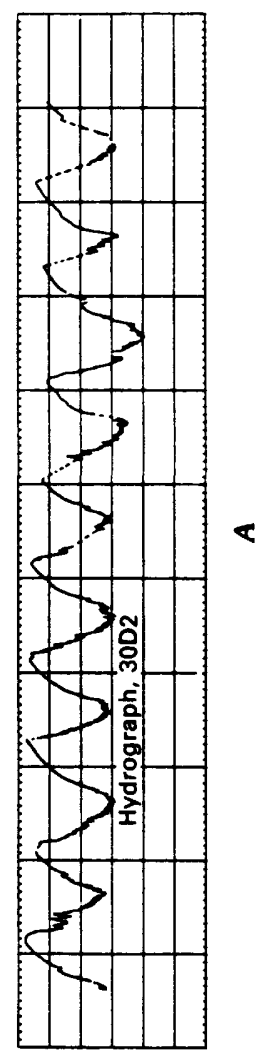

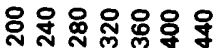

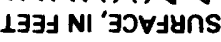
ONVI MO738 YᄏI $\forall M$ OL HLdᄏO

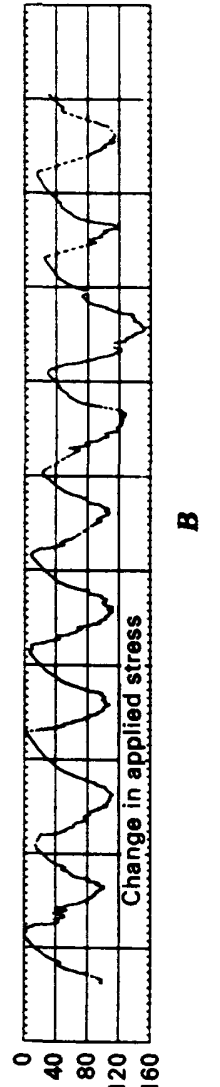

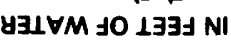
'SS3Y1S 0317dd $\forall$ NI כอNVHO
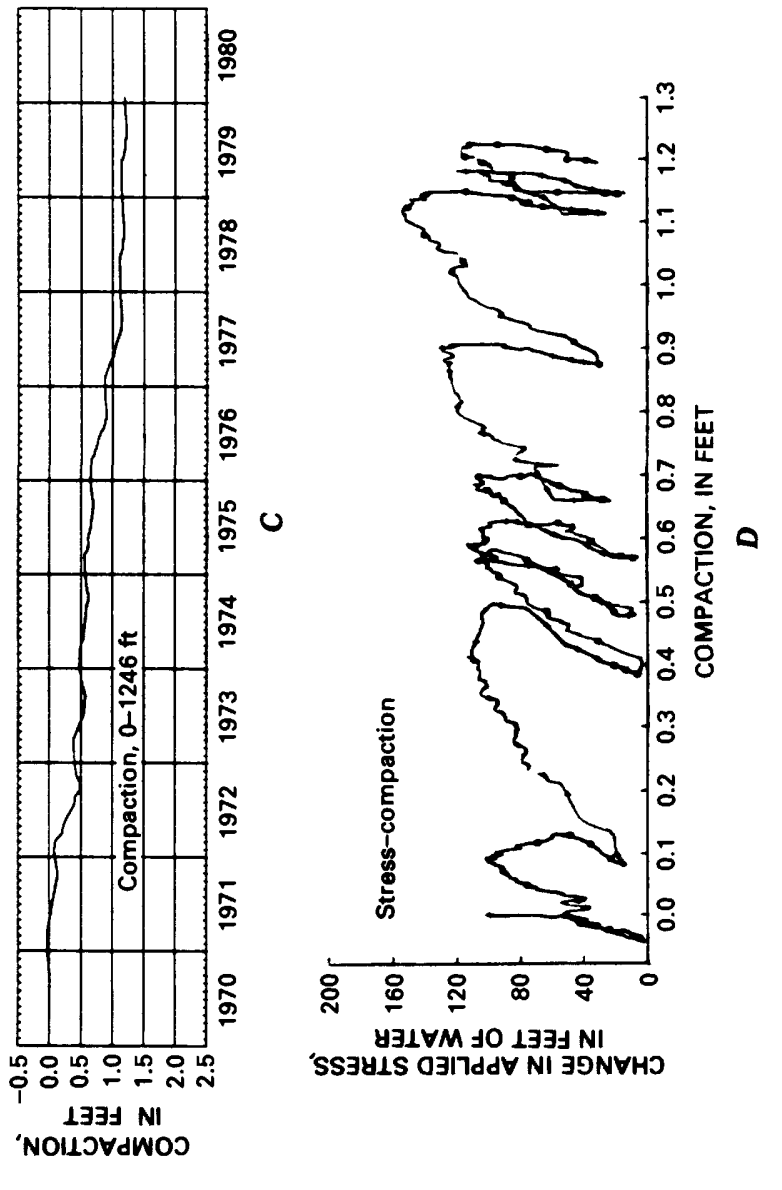


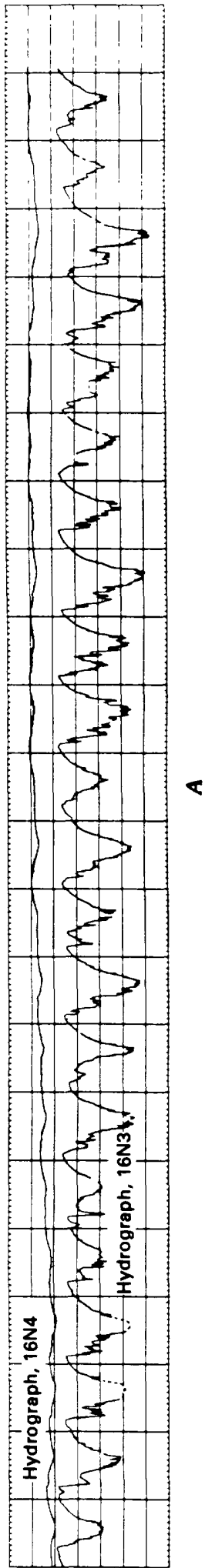

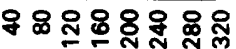

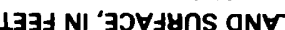
MO738 $831 \forall M$ OI HLd 30

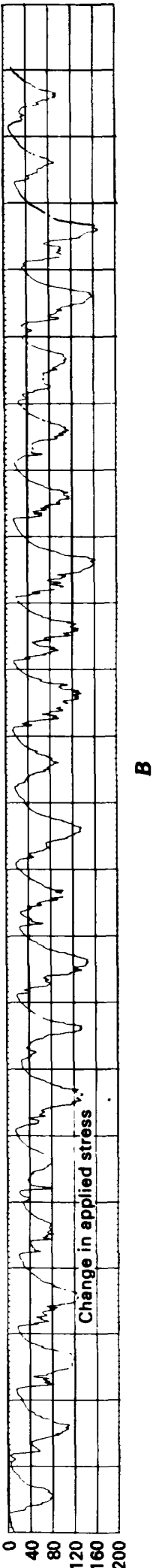

YIIVM JO $1933 \mathrm{NI}$ SS 3 H IS 0317dd $\forall$ NI 3 ON $\forall$ HO
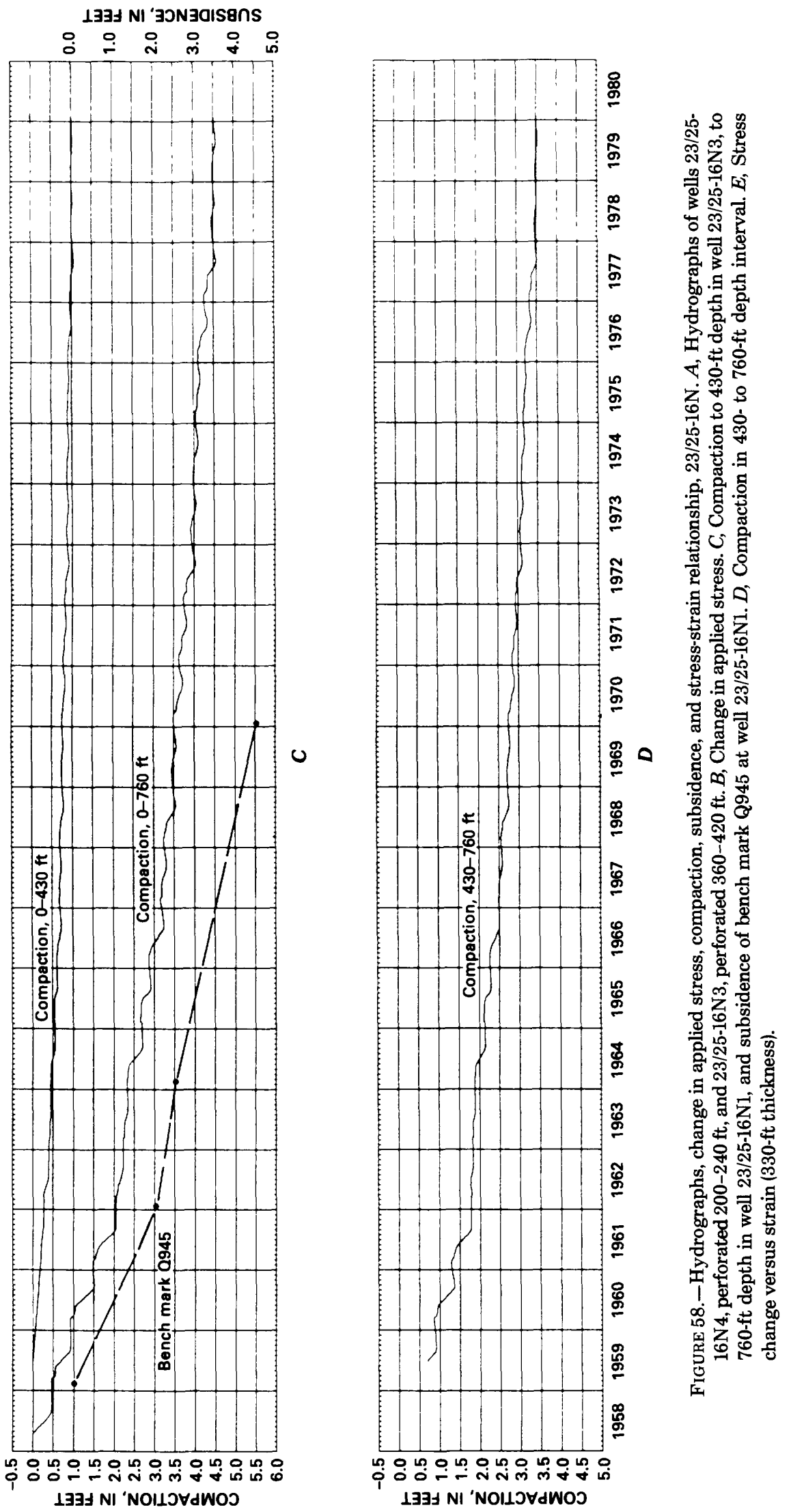


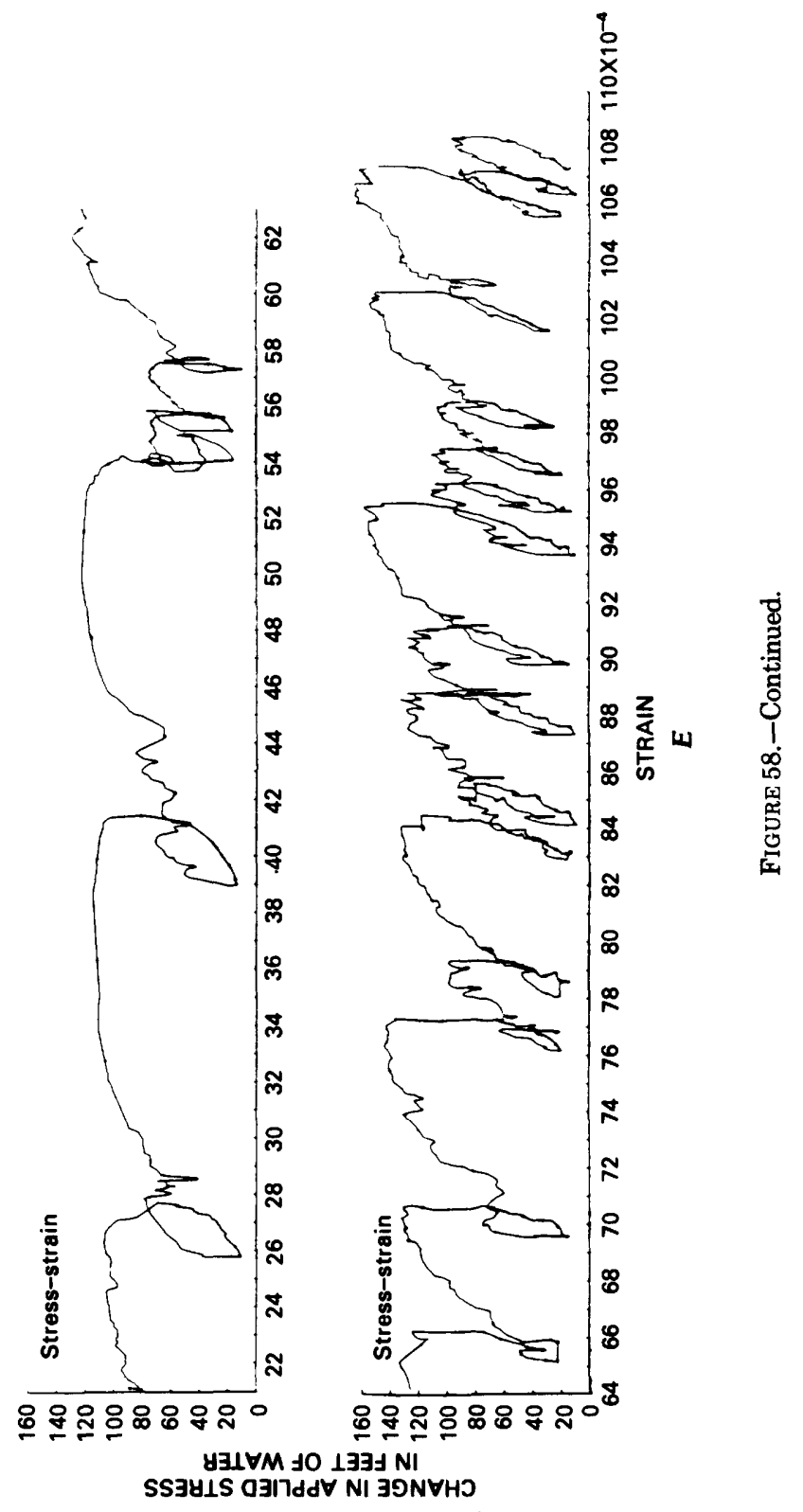




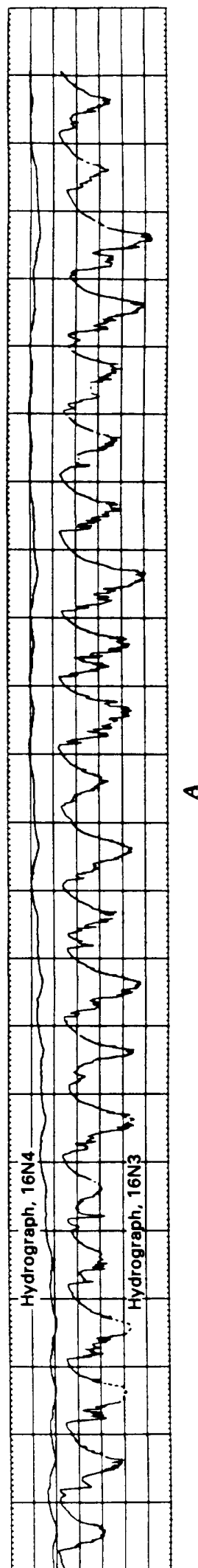

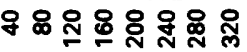

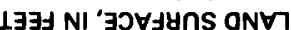
MO738 \& $\exists \perp \forall M$ OI HId $\exists O$

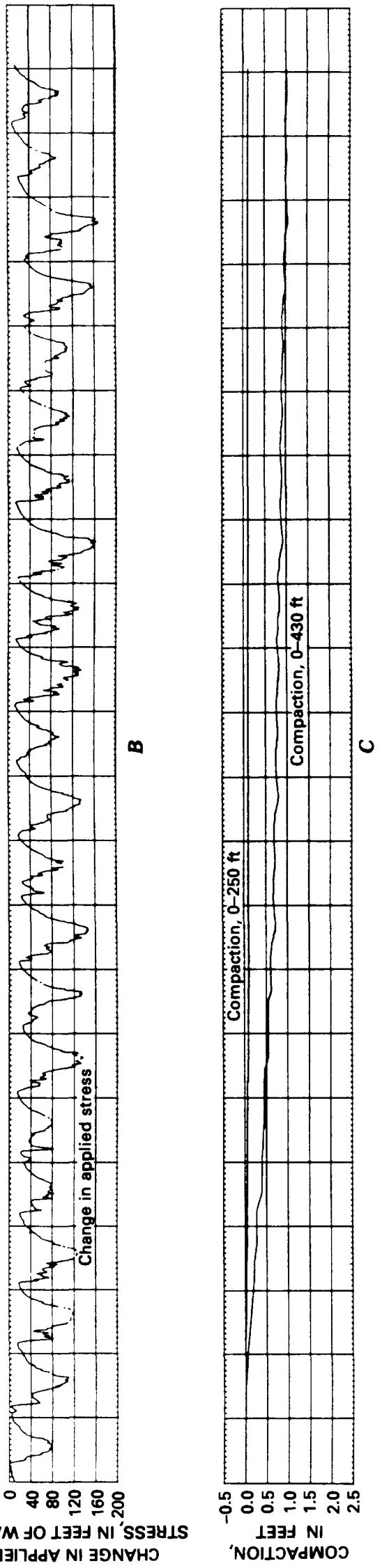




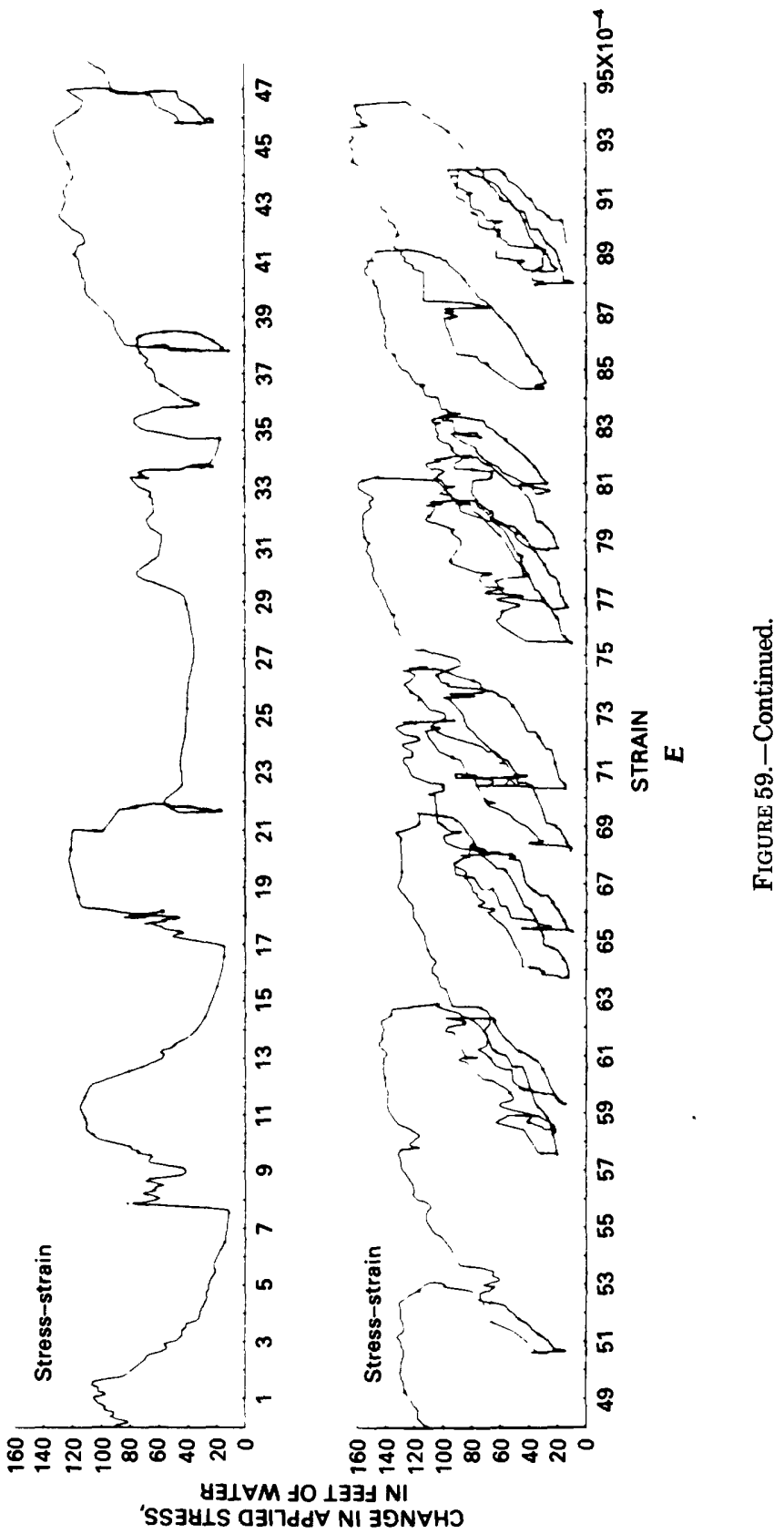



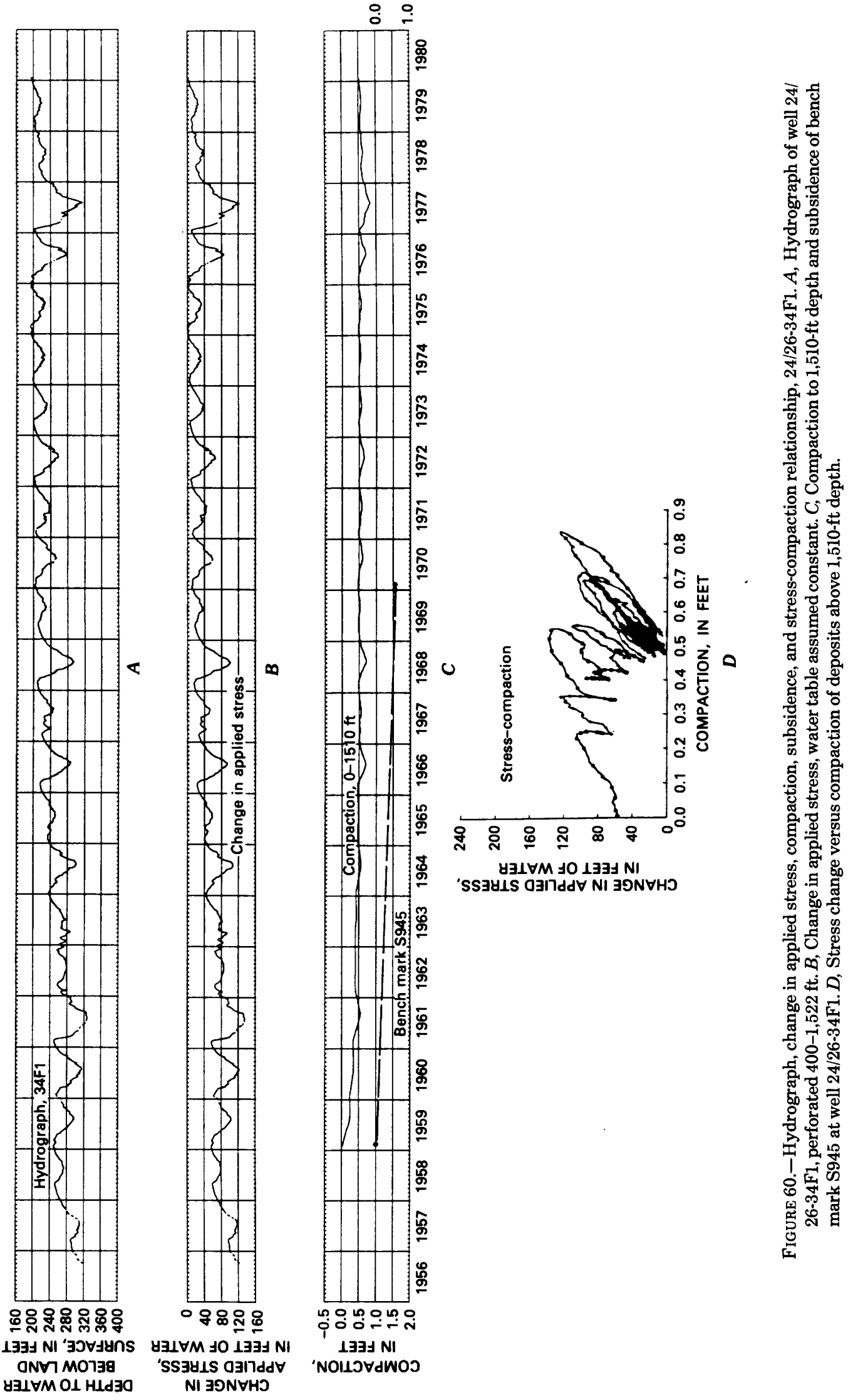


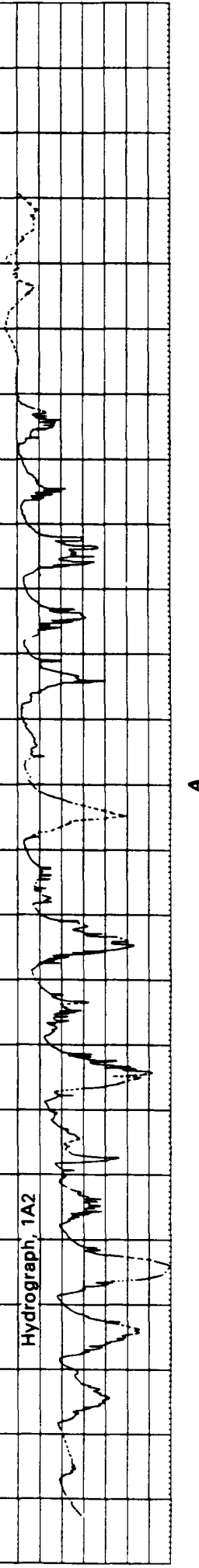

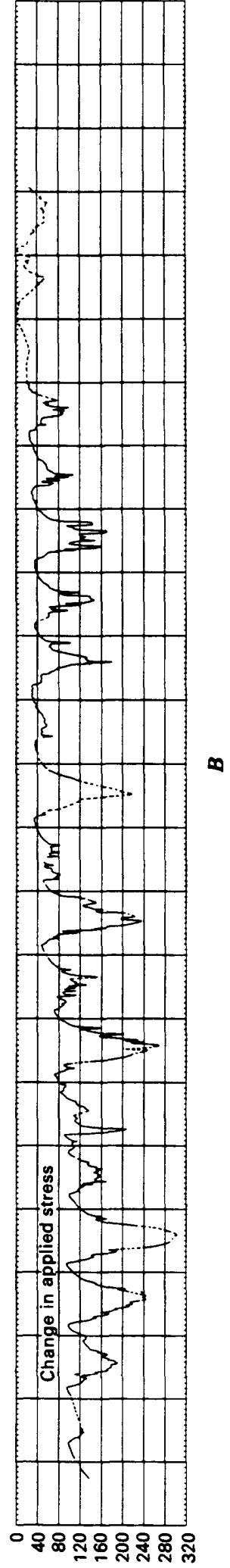

yقL $\forall M$ t0 $\perp \exists \exists \exists \mathrm{NI}$ 'SS3YIS OJI7dd $\forall$ NI $39 N \forall H O$

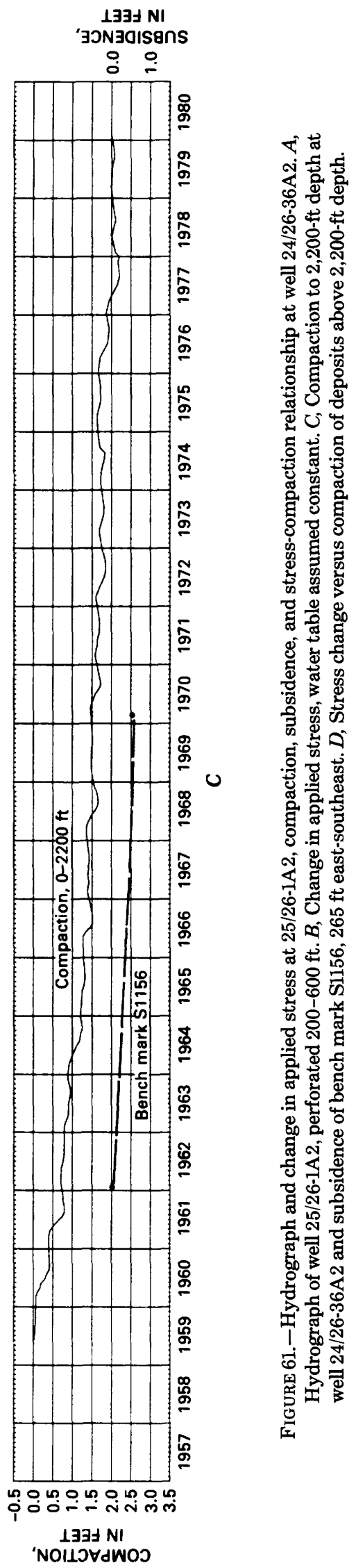




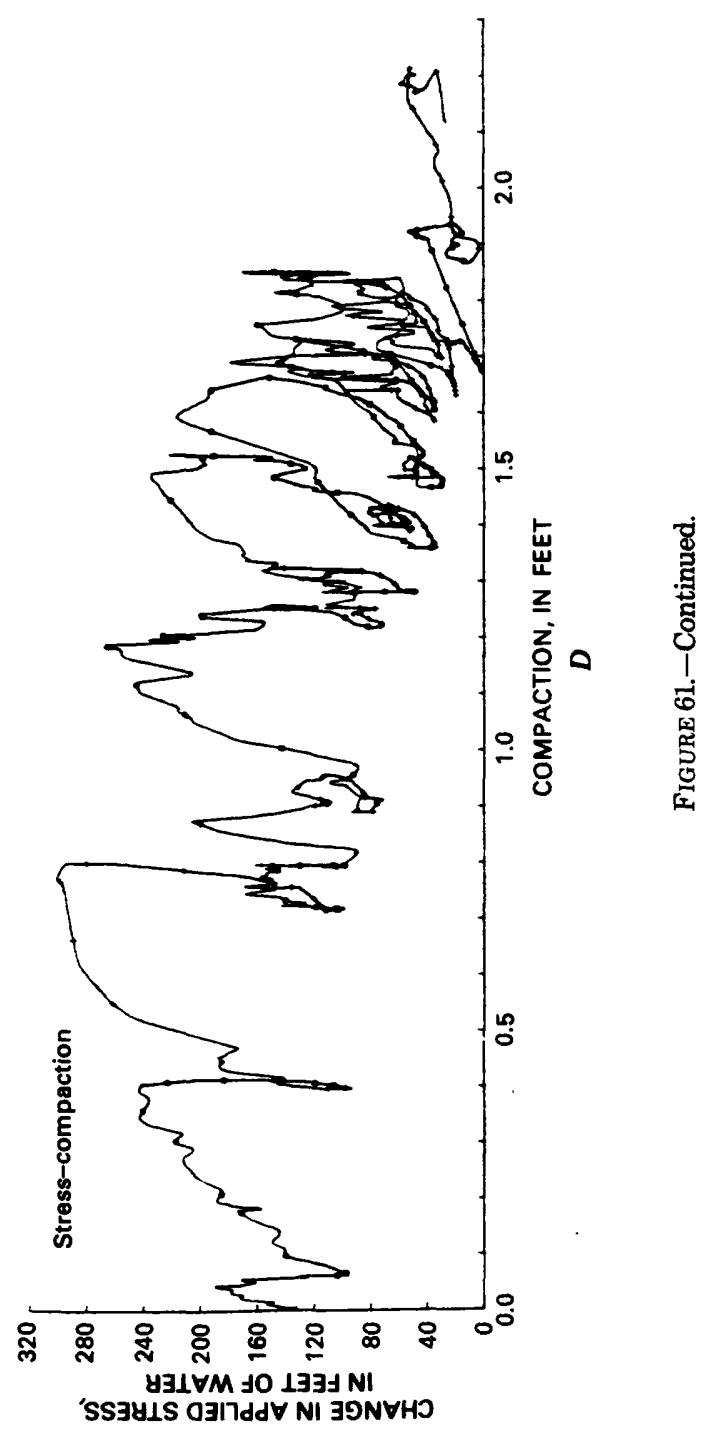




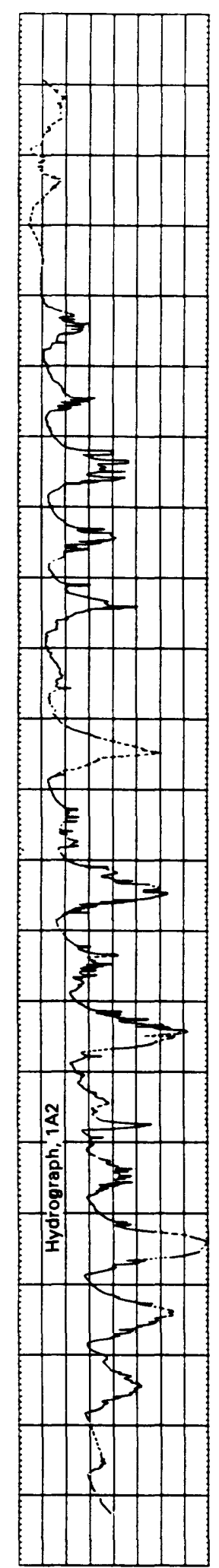

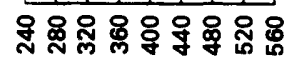

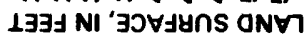
MO138 ४قI $\forall M$ OL HLd 30

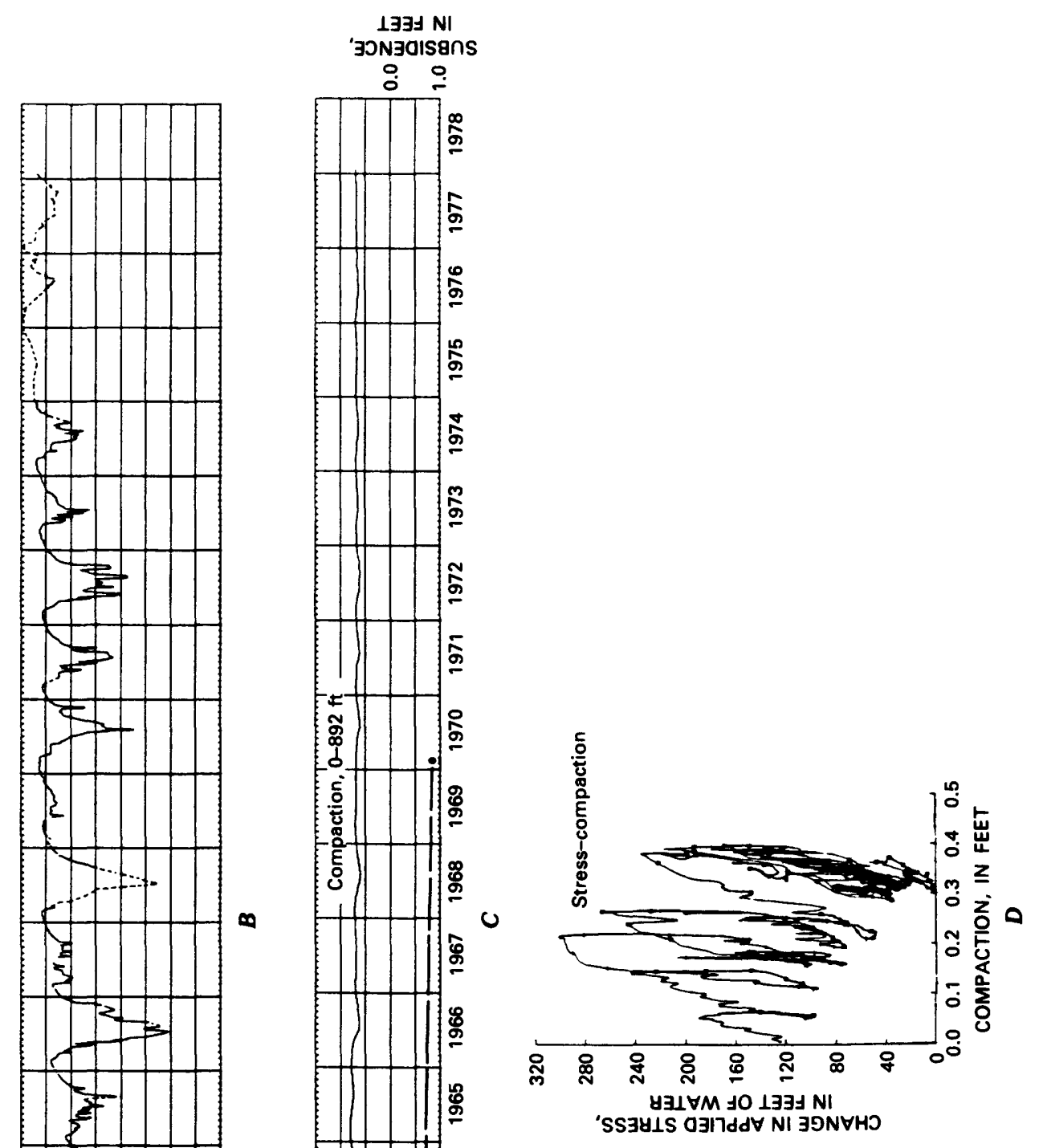

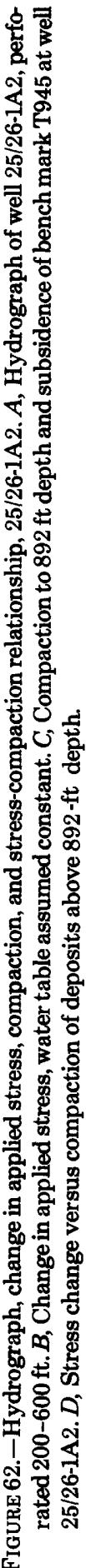

늉웅용영 윰유 Lझᄏy NI NOILO 


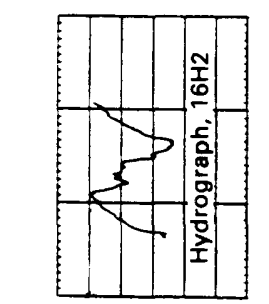

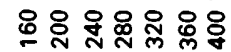

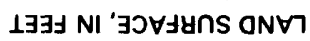

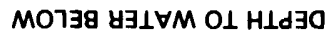

$\varangle$

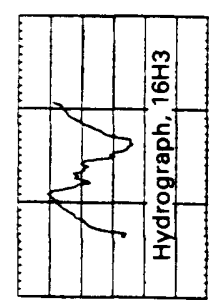

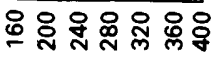
$1 \exists \exists \exists \mathrm{NI}$ 'JJYJYHS ONV MO738 $4 \exists \perp \forall M O \perp H \perp d \exists O$

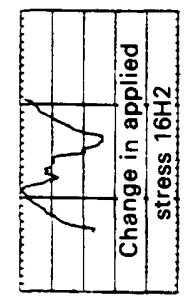

$\circ$ ○这: 융

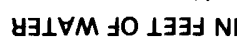
SSFYIS 0 $317 d d \forall$ NI JON $\forall$ HO

$\infty$

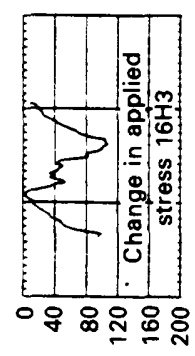

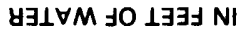
'SS3YIS 03Iרdd NI $\exists$ ON $\forall$ HO

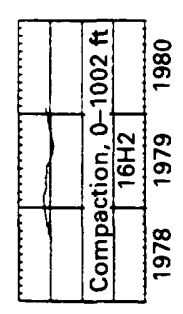

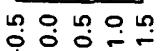

$193 \mathrm{NI}$

NOIIOYAWOJ

u

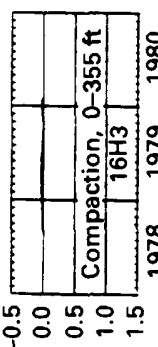

LIJ3 NI

'NOILOVdWOJ

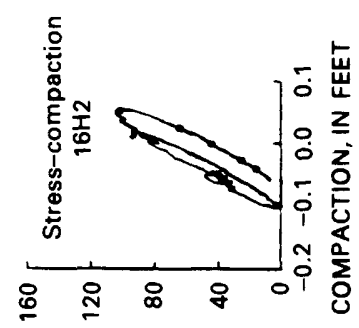

HaI $\forall M+01337 \mathrm{NI}$

'SS $\exists Y \perp S$ 0 $917 d d \forall$ NI $\exists D N \forall H O$
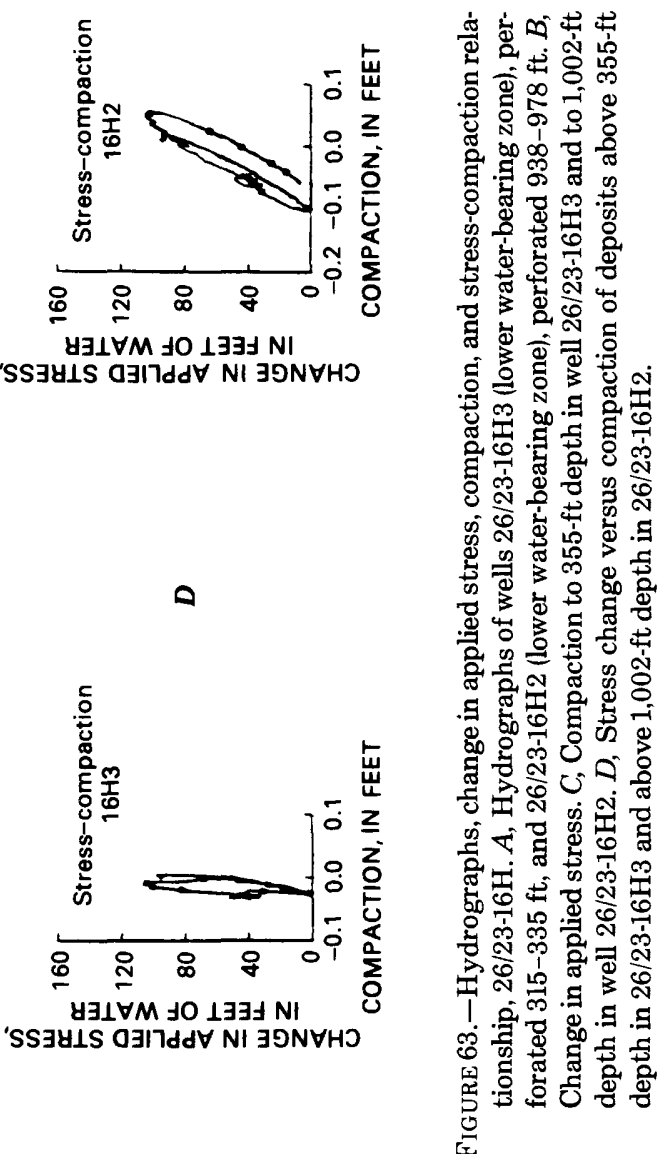


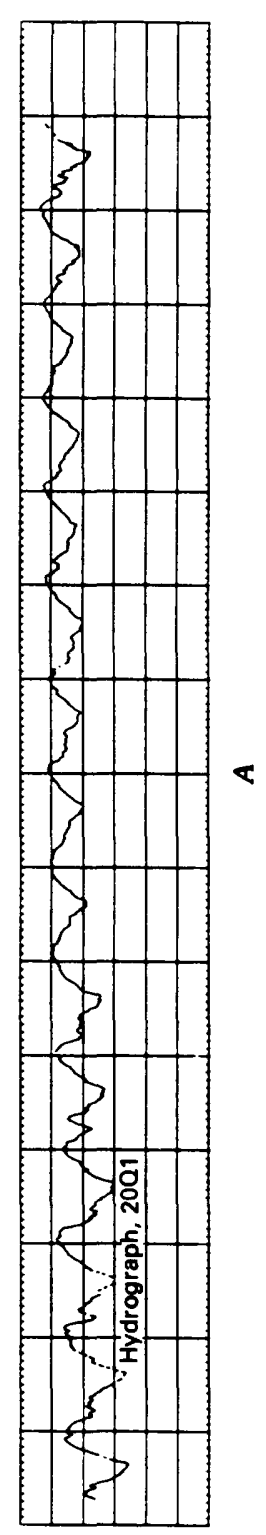

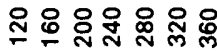

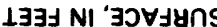
ONV7 MOT38 Y $\perp \forall M O \perp H \perp d \exists O$
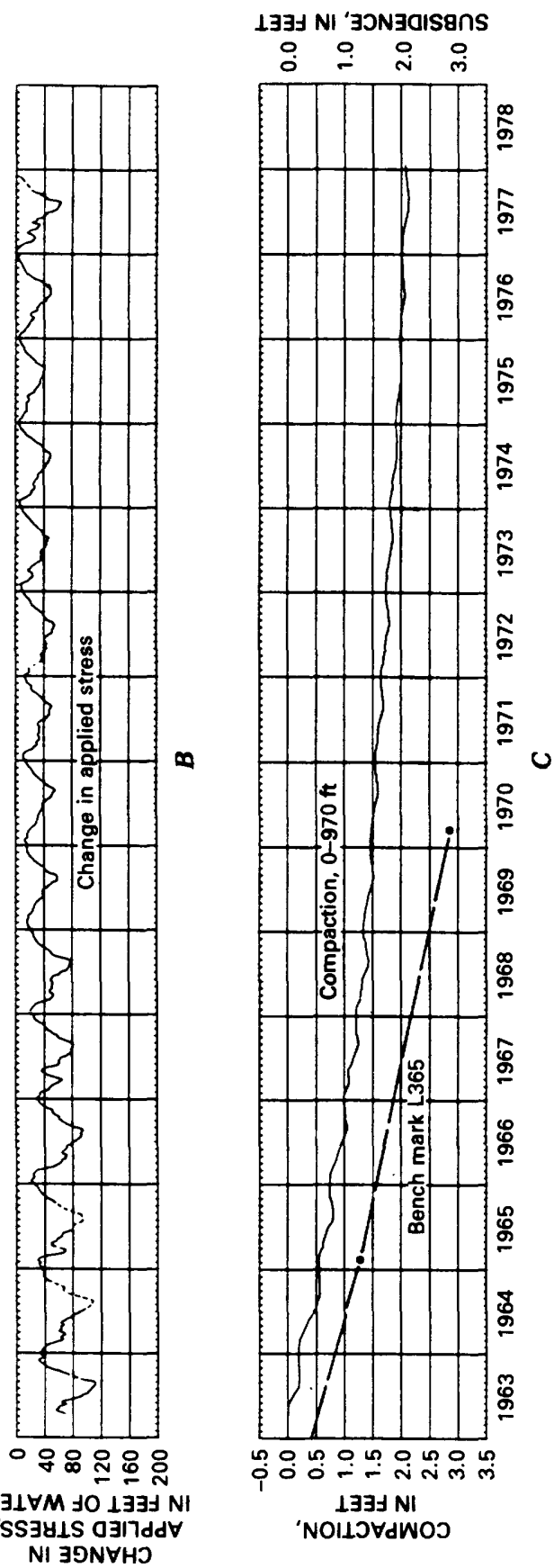

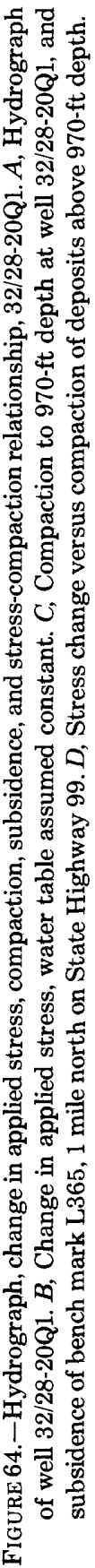



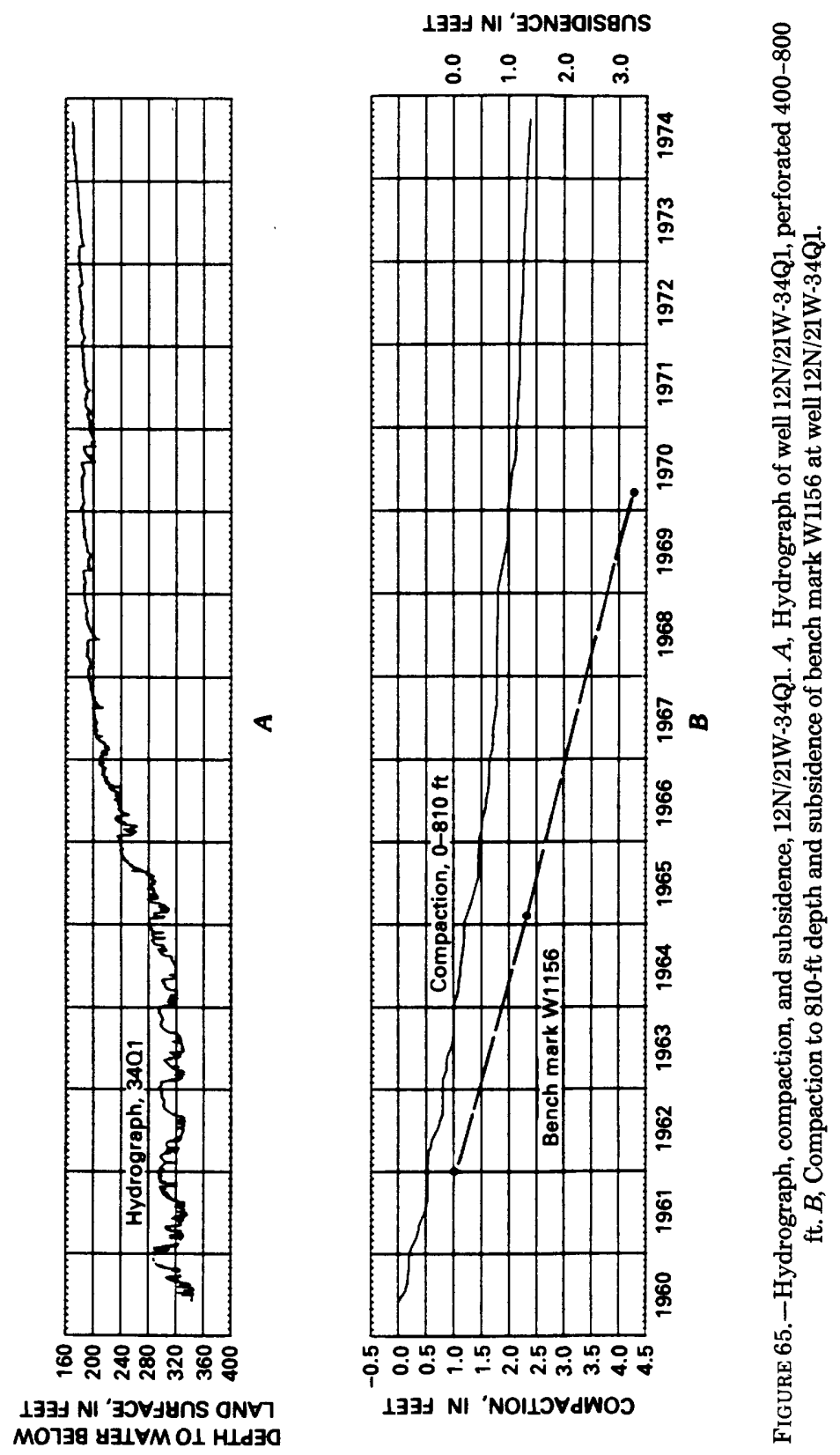

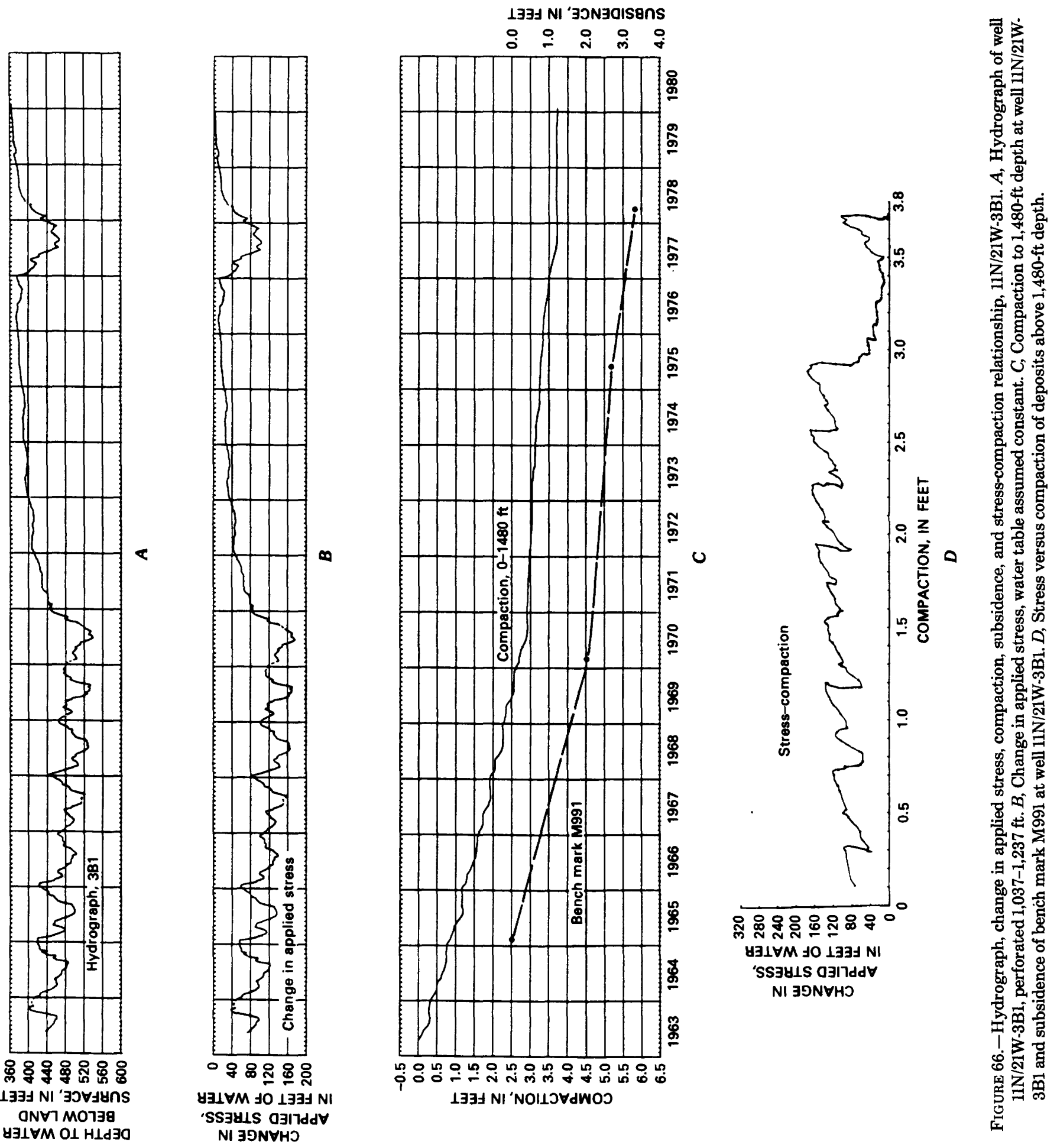
Studies of

Land Subsidence

GEOLOGICAL S U R VEY PROFESSIONAL PAPER 437

This volume was published as separate chapters $A-I$

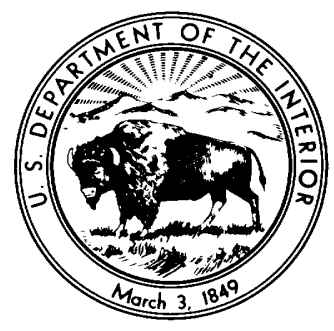




\section{DEPARTMENT OF THE INTERIOR}

WILLIAM P. CLARK, Secretary

\section{U.S. GEOLOGICAL SURVEY}

Dallas L. Peck, Director

For sale by the Distribution Branch, Text Products Section, U.S. Geological Survey, 604 South Pickett St., Alexandria, VA 22304 


\title{
CONTENTS
}

\author{
[Letters designate the chapters]
}

(A) Alluvial Fans and Near-Surface Subsidence in Western Fresno County, California, by William B. Bull.

(B) Land Subsidence due to Ground-Water Withdrawal, Tulare-Wasco Area, California, by B. E. Lofgren and R. L. Klausing.

(C) Prehistoric Near-Surface Subsidence Cracks in Western Fresno County, California, By William B. Bull.

(D) Land Subsidence Due to Ground-Water Withdrawal, Arvin-Maricopa area, California, Ben E. Lofgren.

(E) Land Subsidence Due to Ground-Water Withdrawal in the Los Banos-Kettleman City Area, California, Part 1. Changes in the Hydrologic Environment Conducive to Subsidence, by William B. Bull and Raymond E. Miller.

(F) Land Subsidence Due to Ground-Water Withdrawal in the Los Banos-Kettleman City Area, California Part 2. Subsidence and Compaction of Deposits, By William B. Bull.

(G) Land Subsidence Due to Ground-Water Withdrawal in the Los Banos-Kettleman City Area, California, Part 3. Interrelations of Water-Level Change, Change in Aquifer-System Thickness and Subsidence, by William B. Bull and Joseph F. Poland.

(H) Land Subsidence in the San Joaquin Valley, California, as of 1972, by J. F. Poland, B. E. Lofgren, R. L. Ireland, and R. G. Pugh.

(I) Land Subsidence in the San Joaquin Valley, California, as of 1980 , by R. L. Ireland, J. F. Poland, and F. S. Riley. 